$x+x+x+x-y \quad x+x$ $\therefore \circ \times 1 \times \cdots$ $x \times x \times x \times x \times x-x \times x$ $x+x \times x+x$ $x x+\therefore x \times x \times x x$

\title{
modernismo brasileiro em trânsito: um olhar sobre o registro de viagem
}

$x=x \therefore x \times a x \times x \times x \cdot x$ $\therefore x \times x \times x+x \cdot x+x$ $x+x+x+x+x$ $\because x+x+x+a x+a$ $x=x+x \times x+x \times x-x$ $x+2 x+x+x+x$ $x \times x+x \times x+x \times x+$ $x y+x+x$
$\because \quad x+x$

$x \times x+x-x+x=x$ $x+x+a x$ $\because x<, \therefore \quad \because \quad \cdots$ GABRIELA FARSONIVILLA 2018 


\section{GABRIELA FARSONI VILLA}

\section{modernismo brasileiro em trânsito: um olhar sobre o registro de viagem}

versão corrigida

Dissertação apresentada ao Instituto de Arquitetura e Urbanismo da Universidade de como requisito para a obtenção do título de mestre Área de concentração_Teoria e História da Arquitetura e do Urbanismo Orientador_Prof. Dr. Joubert José Lancha 


\title{
AUTORIZO A REPRODUCAO TOTAL OU PARCIAL DESTE TRABALHO, POR QUALQUER MEIO CONVENCIONAL OU ELETRONICO, PARA FINS DE ESTUDO E PESQUISA, DESDE QUE CITADA A FONTE
}

Ficha catalográfica elaborada pela Biblioteca do Instituto de Arquitetura e Urbanismo com os dados fornecidos pelo(a) autor(a)

\author{
Villa, Gabriela \\ VV712m Modernismo brasileiro em trânsito: um olhar sobre \\ - registro de viagem / Gabriela Villa; orientador \\ Joubert José Lancha. -- São Carlos, 2018. \\ $194 \mathrm{p}$. \\ Dissertação (Mestrado) - Programa de Pós-Graduação \\ em Arquitetura e Urbanismo, Teoria e História da \\ Arquitetura e do Urbanismo - - Instituto de \\ Arquitetura e Urbanismo, Universidade de São Paulo, \\ 2018 . \\ 1. viagem. 2. arquitetura. 3. modernismo. 4. \\ representação. 5. experiência. I. Lancha, Joubert \\ José, orient. II. Título.
}




\section{FOLHA DE JULGAMENTO}

Candidato(a): Gabriela Farsoni Villa

Título da dissertação: “O modernismo brasileiro em trânsito: um olhar sobre o registro de viagem".

Data da defesa: 14/08/2018

Orientador: Prof. Dr. Joubert Jose Lancha

Comissão Julgadora:

$\underline{\text { Resultado: }}$

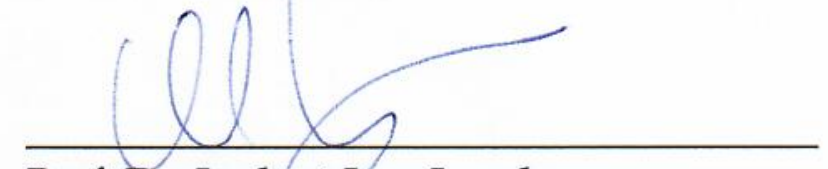

Prof. Dr. Joubert Jose Lancha

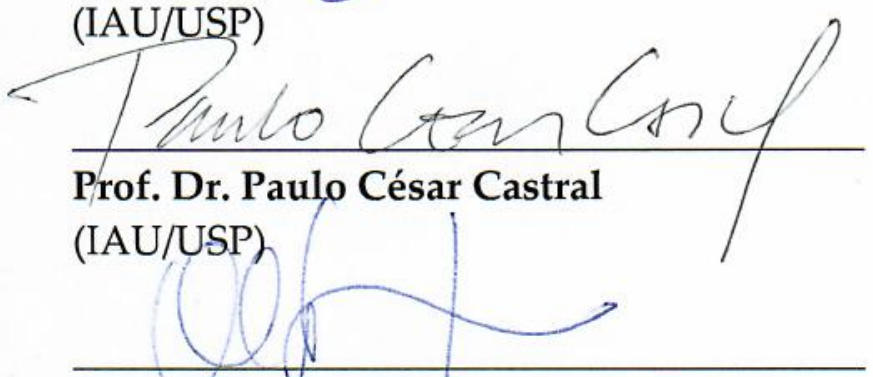

Prof. Dr. Arley Andriolo

(IP/USP)
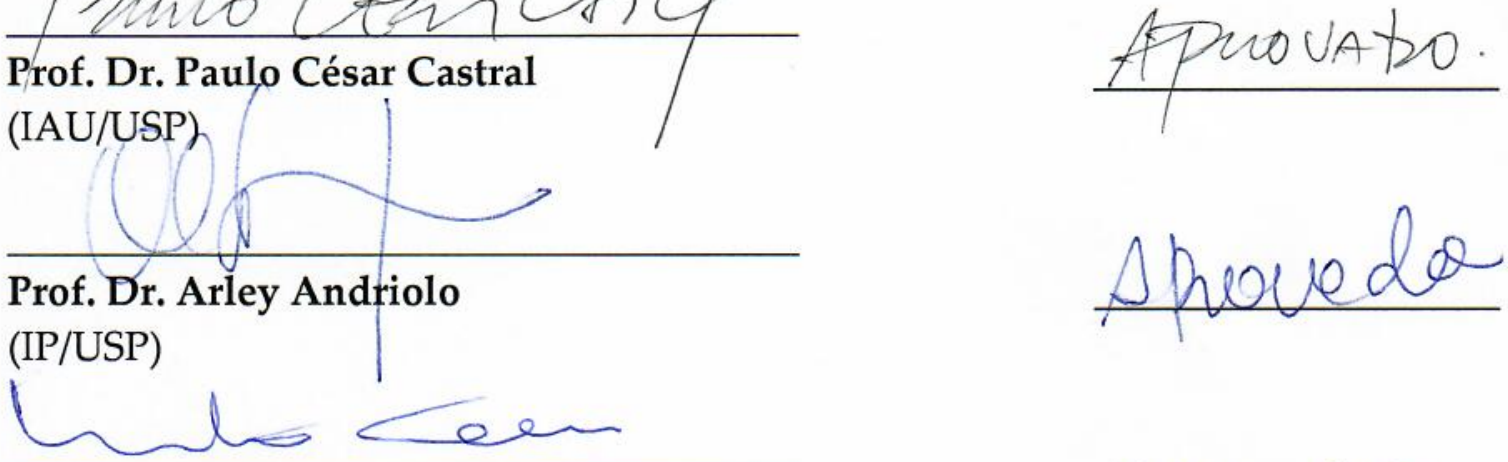

Prof. Dr. Marcelo Carlucci

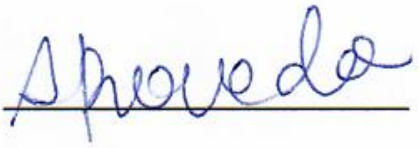

(UNAERP)

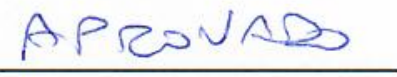

Coordenador e Presidente da Comissão de Pós-Graduação do Programa de PósGraduação em Arquitetura e Urbanismo: Prof. Dr. Tomás Antonio Moreira. 

aos meus pais... 


\section{AGRADECIMENTOS}

à CAPES, pelo período de concessão da bolsa;

ao Joubert, pela orientação generosa, em cada um dos ciclos desse mestrado, pelas referências que construíram este trabalho;

aos meus professores das disciplinas cursada nesses anos, Fábio, Cibele, Simone, Castral, Agnaldo e Wisnick, pelas aulas, pelo conteúdo e pela postura, que me fizeram refletir e amadurecer;

aos professores que conhecem o trabalho desde a banca de qualificação, Castral e Arley Andriolo, pelo primeiro olhar curioso, pelas observações entusiasmadas, pelas correções atentas;

aos funcionários do IAU, da biblioteca, e especialmente às funcionárias da secretaria de pós-graduação, pela eficiência, pelos constantes esclarecimentos;

ao meu grupo de pesquisa, N.ELAC, aos professores Castral, Simone, Givaldo e Fujioka, às colegas das pós-graduação, aos pesquisadores de iniciação científica, pela toda a troca, pela companhia nos eventos, por me inspirarem;

às amigas da graduação, Carol, Natalia, Marina, Eleonora que levo comigo desde 2010, pela amizade, pelo apoio, por tudo que eu cresci ao lado delas, especialmente a Ana Laura e a Jaqueline, que entraram nessa comigo, por compartilharem referências e experiências;

à minha família, principalmente Adalberto, Eloisa, que viveram tudo isso bem de perto, por acreditarem em mim e darem todo o apoio que se pode imaginar;

aos amigos de Brotas, que sempre estiveram comigo, pela diversão, pela paciência, por me acolherem;

à Nana, pela irmã que escolheu ser minha amiga;

e ao Cairo, que quis fazer parte dessa aventura... 


\section{RESUMO}

VILLA, Gabriela Farsoni. O modernismo brasileiro em trânsito: um olhar sobre o registro de viagem. 2018. 194p. Dissertação (Mestrado em Arquitetura e Urbanismo) - Instituto de Arquitetura e Urbanismo, Universidade de São Paulo, São Carlos, 2018.

Aleitura dos produtos deixados por uma viagem nos contam várias histórias, mais do que detalhes da expedição, a forma como o registro foi elaborado nos informa mais sobre o autor, o seu tempo, suas ideias, seus laços. A busca por entender uma época, suas contribuições para a história da arquitetura, das artes, das cidades, das perspectivas formadas num espaço de tempo encontra muitos indícios nas narrativas de viagem deixada por seus personagens. O registro de viagem é compreendido aqui não só como causalidade, mas como momento de produção de perspectivas, de transformação e invenção da história. O registro não é interpretado como notação asséptica, mas em toda a sua fatura, suas escolhas representativas e a expressão que delas decorrem. Dentre essas viagens, a pesquisa toca a experiência brasileira, de modernidade e de alteridades. Uma viagem para muitos viajantes, recortamos o ano de 1924, da incursão a Minas Gerais, de um poeta, um escritor, uma pintora e um arquiteto, como ponto em comum, que marca o início de uma trajetória de pesquisa que esteve presente nas viagens de Blaise Cendrars, Mário de Andrade, Tarsila do Amaral e Lucio Costa. Esse marco comum começa a formular visões de um mesmo Brasil, impulsionando ora novas experiências, repetindo o mesmo método, ora pela via da memória, pelo processo reflexivo, que não é, senão, também uma viagem. Interpretar as peculiaridades e a formação de um grupo mais ou menos coeso a partir da participação dos quatro personagens, através da mediação que cada um faz do sistema espaço-registro-experiência.

Palavras-chave: Viagem. Experiência. Arquitetura. Modernismo. 


\section{ABSTRACT}

VILLA, Gabriela Farsoni. Brazilian modernism in transit: a look at travel logging. 2018. 194p. Dissertação (Mestrado em Arquitetura e Urbanismo) - Instituto de Arquitetura e Urbanismo, Universidade de São Paulo, São Carlos, 2018.

The reading of the products left by a trip tell us many stories, more than journey details, the way the record was elaborated tell us more about the author, their time, their ideas, their ties. The pursuit for learning an age, its contribuitions for the architecture history, for arts, for the cities, for the perspectives formed in a space of time finds many clues in the trip narratives left by their characters. The travelogues are understood not only as causality, but as moment of forming prospects, of transformation and history invention. The record is not interpreted as an aseptic note não, but in their whole facture, their representatives choices and expressions. Among these trips, the research touches the brazilian experience of modernity and otherness. One trip for many travellers. It was elected the year of 1924, the trip to Minas Gerais, taken by a writer, an intelectual, an painter and an architect, that have a common view which marks the beginning of a research trajectory that has been present in the Blaise Cendrars's, Mário de Andrade's, Tarsila do Amaral's and and Lucio Costa's htrips for many years after these. This common mark begins forming differents views of a same Brazil, propelling either new experiences, repeating the same method, or by the memory way, by the reflexive process, wich is notting but also a trip. Interpret the peculiarities and the formation of a somewhat cohesive group from the four characters participation, through the mediation that each one does about the system: space-recording-experience.

Key-words: Trip. Experience. Architecture. Modernism. 


\section{LISTA DE ILUSTRAÇÕES}

Figura 1: Mapa da viagem à Itália. 56

Figura 2: LE CORBUSIER, 1907. Pisa, duomo. 59

Figura 3: Desenho Palácio Ducal. 1845. 60

Figura 4: LE CORBUSIER, 1907. Florença, Santa Croce. Estudo interno. 61

Figura 05: LE CORBUSIER, 1907. Florença, Palazzo Vecchio. 62

Figura 6: LE CORBUSIER, 1907. Palazzo Vechio. 63

Figura 7: LE CORBUSIER, 1907.Florença, Battistero. 64

Figura 8: LE CORBUSIER, 1907. Florença, estudo do campanário de Badia e da torre de Bargello. 64

Figura 9: LE CORBUSIER. 1907. Florença, estudo da Cartuxa de Ema, 15 de setembro de 1907. 65

Figura 10: LE CORBUSIER, 1907. Siena, estudo da Piazza del Campo. 29 de setembro e 5 de outubro de 1907. 66

Figura 11: Mapa da viagem ao oriente. 67

Figura 12: Foto de Le Corbusier em viagem ao Oriente. 69

Figura 13: LE CORBUSIER, 1910-1911. croqui viagem ao oriente. 70

Figura 14: LE CORBUSIER, 1910-1911. aquarela viagem ao oriente. 71

Figura 15: LE CORBUSIER, 1910-1911. croqui viagem ao oriente. 72

Figura 16: LE CORBUSIER, 1910-1911. croqui viagem ao oriente. 72

Figura 17: LE CORBUSIER. 1910-1911.croqui viagem ao oriente. 72

Figura 18: MARTIUS. Detalhes morfológicos das espécies botânicas. 82

Figura 19: MARTIUS. 1828.Alsophila armata e didymochaena sinuosa na paisagem. 85

Figura 20: DI CAVALCANTI. Cartaz Semana de Arte Moderna. 1922. 98

Figura 21: Foto modernistas visitam Minas Gerais. 1924. 100

Figura 22: VILLA, 2018. Diagrama de organização dos desenhos na prancha. 107

Figura 23: VILLA, 2018. Foto da capa de "Arte religiosa no Brasil". 132

Figura 24: ANDRADE, Mário de. Fotografia das viagens etnográficas. 137

Figura 25: LÉGER. Fernand. 1919. Les hommes dans la ville. 140

Figura 26: AMARAL, Tarsila do. 1924. Esboços série viagem a Minas Gerais. 142

Figura 27: AMARAL, Tarsila do. 1928. 0 Abaporu. 143

Figura 28: AMARAL, Tarsila do. 1924. Capa de "Feuilles de Route". 144

Figura 29: AMARAL, Tarsila do. serra da Mantiqueira - Rio Paraíba. 
(Ilustração publicada no livro Feuilles de Route, p.64.) 1924. 145

Figura 30: AMARAL, Tarsila do. 1924. Carnaval em Madureira (croqui). 146

Figura 31: AMARAL, Tarsila do. 1924. Carnaval em Madureira. 147

Figura 32: AMARAL, Tarsila do. 1924. Ouro Preto II. 148

Figura 33: VILLA, 2018. Diagrama comparativo do campo visual. 150

Figura 34: AMARAL, Tarsila do. 1924. São João del Rei: rua com igreja ao fundo. 151

Figura 35: VILLA, 2018. Diagrama comparativo temático. 152

Figura 36: VILLA, 2018. Diagrama de elementos de composição com croquis de Tarsila do Amaral. 153

Figura 37: AMARAL, Tarsila do. 1924. E.F.B.C. 153

Figura 38: AMARAL, Tarsila do. 1924. Morro de Favela. 154

Figura 39: VILLA, 2018. Diagrama observação Minas. 155

Figura 40: VILLA, 2018. Diagrama composição Minas. 156

Figura 41: VILLA, 2018. Diagrama observação Carnaval no Rio de Janeiro. 156

Figura 42: VILLA, 2018. Diagrama composição Carnaval no Rio de Janeiro. 156

Figura 43: VILLA, 2018. Desenho observação Ilustrações. 157

Figura 44: VILLA, 2018. Diagrama composição Ilustrações. 157

Figura 45: AMARAL, Tarsila do. 1924. Ouro Preto. 158

Figura 46: COSTA, Lucio. fotografia de Lucio Costa e grupo em viagem em 1924. 160

Figura 47: COSTA, Lucio. 1924. aquarela passadiço de Diamantina. 162

Figura 48: COSTA, Lucio. 1924. aquarela interna de Igreja em Diamantina. 163

Figura 49: VILLA, 2018. Diagrama de organização dos desenhos na prancha. 164

Figura 50: VILLA, 2018. Diagrama temático. 165

Figura 51: COSTA, Lucio. 1924. estudo de beirais, Diamantina. 166

Figura 52: COSTA, Lucio. 1924. janela da Igreja N. S. do Carmo, planta e seções dos detalhes, Diamantina. 167

Figura 53: COSTA, Lucio. 1927. Croqui de Braga, Casa dos crivos. 169 


\section{LISTA DE ABREVIATURAS}

L.C.: Lucio Costa

M.A.: Mário de Andrade

T.A.: Tarsila do Amaral

B.C.: Blaise Cendrars

O.A.: Oswald de Andrade

O.P.: Ouro Preto

IPAHN: O Instituto do Patrimônio Histórico e Artístico Naciona

SPHAN: Serviço do Patrimônio Histórico e Artístico Nacional

IEB: Instituto de Estudos Brasileiros

IHGB: Instituto Histórico e Geográfico Brasileiro 



\section{SUMÁRIO}

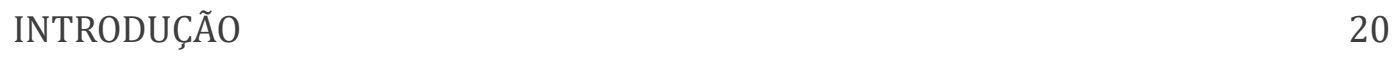

CAPÍTULO UM_UMA HISTÓRIA DAS VIAGENS DE FORMAÇÃO 27

_Grand tours"

_ideias de viagens $\quad 50$

_a ideia de aventura 51

_viagem e ciência

_mecenato 53

_viajantes típicos, viajantes tipo $\quad 54$

_Le Corbusier, arquiteto moderno em trânsito $\quad 54$

$\begin{array}{ll}\text { CAPÍTULO DOIS_VIAGENS BRASILEIRAS } & 75\end{array}$

_olhares sobre o Brasil $\quad 78$

$\begin{array}{ll}\text { _primeiros viajantes } & 79\end{array}$

_viagens acadêmicas $\quad 89$

_no Brasil moderno $\quad 96$

_o caráter de iniciação da viagem a Minas Gerais $\quad 103$

CAPÍTULO TRÊS_DAS LEITURAS DOS REGISTROS 112

_relatos textuais 116

$\begin{array}{lr}\text { _b.c. } & 117\end{array}$

$\begin{array}{ll}\text { - da estrutura de feuilles de route } & 118\end{array}$

$\begin{array}{lr}- \text { o percurso } & 120\end{array}$

$\begin{array}{ll}- \text { a escrita } & 121\end{array}$

$\begin{array}{lr}\text { _versões e edições } & 123\end{array}$

_o tema do Brasil | ideia de viagem $\quad 124$

_m.a. 128

$\begin{array}{lr}\text { _mario viajante } & 130\end{array}$

_literatura e registro em "A Arte religiosa no Brasil"

_-viagens etnográficas" a partir de $1927 \quad 136$

$\begin{array}{lr}\text { _relatos visuais } & 139\end{array}$

$\begin{array}{lr}\text {-t.a. } & 139\end{array}$

_ o desenho como registro de viagem 143

_ desenhos da série ilustrações, de "Feuilles de Route" 144

_ desenhos da série Carnaval no Rio de Janeiro, em $1924 \quad 146$

_desenhos da série viagem a Minas Gerais, em $1924 \quad 148$

$\begin{array}{ll}\text { l.c. } & 158\end{array}$

_a viagem a Diamantina no percurso formativo de Lucio Costa 159

$\begin{array}{ll}\text { _as pranchas e as aquarelas, o tom do registro } & 162\end{array}$

$\begin{array}{lc}\text { _outras viagens } & 168\end{array}$

$\begin{array}{lr}\text { CONSIDERAÇÕES FINAIS } & 170\end{array}$

REFERÊNCIAS BIBLIOGRÁFICAS 176

$\begin{array}{ll}\text { ANEXOS } & 186\end{array}$ 
INTRODUÇÃO 


A história das viagens de formação perpassa a ideia de viagem moderna como a conhecemos, mas são nas viagens antigas que encontramos, no entanto, suas origens, suas estruturas, suas motivações.

Os primeiros modelos de viagem de formação foram caracterizados pelos "grand tours", prática que consistia na visitação por um longo período de tempo aos lugares canônicos, berço do nascimento da cultura ocidental, no qual Roma era sua maior expressão. Os viajantes que faziam essas incursões, nesse primeiro momento, eram membros da aristocracia ou tinham suas viagens financiadas em forma de prêmio. Ao se depararem com essas cidades, templos, culturas, os aspirantes a arquitetos, pintores, artistas se formavam.

As viagens conservam, em cada época, uma determinada relação com a história. Se na antiguidade, a história representava um passado a ser valorizado, um passado entendido estilisticamente, a renascença inaugura, por sua vez, novos observadores, com uma maior carga objetiva e científica, incitando, por exemplo, os deslocamentos percorridos na época das grandes navegações, que só foram possíveis dentro daquele contexto cultural e técnico.

A ideia moderna de viagem tem sua raiz na motivação científica, própria da história do Renascimento e também do período Iluminista. Há, nesse tipo de viagem, uma preocupação objetiva, que, no entanto, não anula a dimensão do passado do local que se explora, mas que dialoga com o presente daquele viajante, no sentido de pensar o futuro a partir das lições do passado.

Essa visão inaugura, então, além de novas estruturas e formatos, uma outra relação com a história, não só em termos de viagem, mas na sociedade moderna em seu sentido mais amplo, a qual se vê obrigada a confrontar novamente a dimensão da história para traçar seus rumos para o futuro. De acordo com a discussão de Gonçalves (2012), o viajante moderno foi na história buscar as fontes para reinventá-la.

Le Corbusier retrata bem a experiência de um arquiteto viajante, a experiência de Le Corbusier em suas viagens, a partir de 1907, ilustra como essa relação, passado, presente e possibilidades de se projetarh um futuro se desenvolve na pesquisa do arquiteto.

As viagens de formação no âmbito moderno configuraram um momento de análise e de reavaliação das referências do viajante, a partir do contato sensorial, fenomenológico que se dá no lugar.

Como um conceito chave da abordagem fenomenológica de Merleau Ponty, a viagem é entendida como um movimento através do tempo e do espaço, os registros são a mediação da experiência da viagem como processo reflexivo de 
conhecimento. A matéria externa, do espaço da viagem e seus acontecimentos são entendidos sob uma perspectiva consciencial, como fenômeno.

Se a viagem é possibilidade de aprendizado, nela o conhecimento se dá, ainda na concepção de Ponty, não só na capacidade de perceber o mundo que está ao redor do viajante, mas também na atribuição de significados àquilo que veio ao sujeito através da percepção. Em todo o processo há um diálogo entre exterior e interior, produzindo uma compreensão de ordem fenomenológica.

A dimensão reflexiva do aprendizado em viagem é possível dentro do contexto da ambiguidade moderna, que viaja para conhecer o mundo e a si próprio. É nesse sentido que podemos ler algumas viagens e juntamente a elas o surgimento de alguns personagens, como o pintor Paul Gaugin, o escritor Goethe, para eles, a viagem passou a significar uma possibilidade de aventura, de criação de histórias e personagens emblemáticos, da construção de alteridades nos próprios viajantes.

A viagem passou então a construir a história e personalidades, objetos e sujeitos. Essa interpretação das primeiras viagens modernas tem muito a ver com os questionamentos de natureza existencial do início do modernismo, de certa forma, da construção do ego dos sujeitos e sua afirmação.

A viagem passou a representar uma possibilidade de se não resolver, intensificar os questionamentos dos sujeitos modernos. Ao longo de algumas experiências, há a transformação do sujeito em si, que amplia seu nível se percepção e acumula bagagens na forma de experiência.

0 acúmulo do qual se fala pode ser interpretado como esse ganho de espessura do mundo, que acontece na percepção do viajante:

[...] o sentido do aprendizado é, portanto, o do aumento de camadas designáveis do sensível, resultando em uma espécie de ganho de espessura por parte do mundo percebido. (ENGEL, 2009)

A partir do contato com o desconhecido, o exterior começa a ser compreendido com a mediação da percepção, que opera na transmissão de dados.

Viagens, especialmente o tipo que tratamos nessa pesquisa, geram registros, fragmentos que contém informações sobre os espaços visitados, sobre uma época, mas são, para além de seu caráter informacional, objetos de representação, que podem ser lidos em sua fatura, como narrativas da biografia de quem os produziu.

É possível entender então, a representação como um produto construído a partir interpretação de cada sujeito, que é, por sua vez, a soma de suas 
experiências acumuladas, sobre o exterior, que é de certa forma, a projeção do que lhe é interno.

No primeiro capítulo será percorrida a história das viagens como prática de formação de estudantes, pesquisadores, artistas pela via da disciplina que essa prática constituiu.

Nessa história, compreende-se a consolidação da disciplina a partir do mapeamento dos itinerários, desde os itinerários clássicos até as transformações de mentalidade, de contextos históricos e culturais que ampliaram os endereços das viagens, o interesse romântico pelo exótico, pelo pitoresco, as interpretações modernas acerca dos destinos fora do ocidente ou mesmo por regiões com tradições populares dentro de suas próprias fronteiras nacionais.

Ao expor procedimentos e estruturas próprias da viagem de formação, adquire-se meios para analisar as transformações que a disciplina vem sofrendo, assim como entender algumas origens, motivações e práticas comuns, que perpassam a história de uma época ou de outra.

A viagem pode ser explorada como técnica, como prática de profissionais de arquitetura e de outras áreas do conhecimento, como por exemplo: a viagem técnica do botânico, de escritores, historiadores, artistas. Pensar a multiplicidade de áreas é importante com o intuito de recuperar a essência dessa prática, no sentido da experiência que o ato de viajar provoca, pensando sobre as similaridades dos procedimentos e registros.

Entende-se que a viagem tem o potencial de intensificar questionamentos individuais e sociais para os sujeitos, de delinear as alteridades de quem as percorre ou interpretá-las nos espaços que são percorridos.

Já no segundo capítulo, a ênfase ocorre na experiência brasileira no campo das viagens de formação, a partir das referências teóricas de leitura discutidas no primeiro capítulo.

O capítulo inicia com a recuperação dos primeiros momentos em que o Brasil aparece como tema das viagens de formação, na história. Nesse primeiro momento, o Brasil é narrado por intérpretes estrangeiros, nas chamadas expedições exploratórias, naturalistas, com intenções catalogadoras e descritivas, da cultura e do território físico do país.

Num segundo momento, aparece com significativa importância a viagem na formatação "clássica", que corresponde aos "grand tours", invertendo, nesse momento os papéis e os destinos, as viagens acadêmicas brasileiras eram endereçadas à Europa, com o intuito de complementar a formação de 
estudantes, artistas.

De dentro dessa prática acadêmica com estruturas bem definidas até então, no entanto surgiram experiências que subverteram a lógica dos clássicos e passaram a incorporar outros destinos, dessa vez, pra dentro do próprio país. Essas foram as viagens de estudantes de encontro à arte barroca brasileira, pensadas e patrocinadas por integrantes do movimento neocolonial.

Essa prática que teve início dentro do movimento neocolonial foi mais tarde reivindicada por integrantes e desenvolvedores do movimento moderno nas artes no Brasil, sob uma nova perspectiva, dialogando e confrontando com os conceitos e interpretações que o neocolonial havia produzido até então.

0 ano de 1924 teve peculiar importância por constituir, a partir da experiência da "viagem de redescoberta do Brasil" nas cidades históricas de Minas Gerais, um índice de uma série de pesquisas acerca do Brasil popular, de suas tradições culturais, arquitetônicas, artísticas, sociais com questionamentos comuns aos viajantes do período moderno, ajudando na construção de um imaginário artístico para o país. Dessa viagem "marco", analisamos as trajetórias de quatro personagens-viajantes: Blaise Cendrars, Tarsila do Amaral, Lucio Costa e Mário de Andrade.

Depois de compreender a importância histórica e o caráter de iniciação das pesquisas sobre o Brasil, de uma visão moderna, em 1924, se faz necessário identificar como as experiências vividas em viagem os registros atuaram nas produções artísticas, literárias, arquitetônicas dos personagens em questão. Para isso utilizamos do mapa em escala temporal que justapõe a coleção de registros produzidos nas viagens de formação brasileiras, com abertura para uma análise formal dos formatos, da expressão e das informações contidas nos documentos.

No terceiro capítulo, é feita a leitura dos registros, visuais e textuais de cada um dos personagens, recortando o período do ano de 1924, em que se nota um adensamento dos registros e uma simultaneidade entre as pesquisas dos quatro personagens-viajantes.

Nessa etapa, o primeiro conjunto de registros recortados para leitura, corresponde ao livro de poesias sobre o tempo que o poeta Blaise Cendrars passa percorrendo o território brasileiro. Nesse caderno de poemas, o país é descrito em uma forma de registro textual, mas profundamente visual, na medida em que os poemas se apresentam como cartões postais.

Já a produção de Tarsila ficou concentrada sobre os croquis que a artista produziu durante três momentos da viagem, no ano de 1924, possíveis de se 
ler em séries, a correspondente ao Carnaval no Rio de Janeiro, à Semana Santa nas cidades mineiras e ao conjunto de desenhos que constam no caderno de poemas "Feuilles de Route", de Blaise Cendrars, ilustrado por ela.

Nesse mesmo ano de 1924, Lucio Costa, enquanto estudante de arquitetura realiza viagem muito semelhante à do grupo modernista, no qual estão presentes os outros três personagens-viajantes desse trabalho, e trás, dessa viagem de estudos, desenhos de teor documental, sobre o patrimônio da arquitetura colonial brasileira, e foram esses os registros recortados para análise.

Já Mario de Andrade, como membro do grupo modernista em questão, é integrante importante da chamada "viagem de descobrimento do Brasil". Mas Mario, antes da viagem de apresentação de Minas ao grupo, realiza uma incursão no ano de 1919, no qual escreve um relatório em crônicas, "Arte religiosa no Brasil", que já anuncia a visão do intelectual, que retorna à "questão", na forma de viagem, em 1924.

A partir da análise mais alargada desses documentos, foi possível compreender a "ideia" que é tão latente no instante do registro, onde ainda não há a pretensão da obra acabada, é pura potência, e ver como um, registro e obra acabada, se retroalimentam. 
CAPÍTULO UM_UMA HISTÓRIA DAS VIAGENS DE FORMAČ̃̃ 


Partir...[é] Nostalgia de um além: de um mundo melhor, mas também desgosto da realidade. Forma moderna de inquietação, a viagem é, no espaço, a réplica da constante peregrinação do espírito individual, da busca de uma transcendência e da sua fuga diante de sí próprio. (CHARBONNEAU, 1991, p.13)

Existem várias formas de observar e apresentar a história das viagens de formação; poderíamos percorrer e construir um grande quadro generalista ou estabelecer um preciso recorte, via um período específico ou selecionando e valorizando um viajante e colocando esse em confronto com os demais. 0 caminho escolhido aqui é aquele que reconhece as práticas, desenvolvidas por alguns viajantes, como um campo específico de experimento. Ou seja, a tática é reconhecer nessas práticas, técnicas comuns que nos forneça pistas para contar "uma história", apostando que ao dirigir esse olhar para muitas dessas experiências possamos através de suas comuns particularidades, compreender um significado amplo e generoso.

Essa particularidade, essa coisa comum a todas as experiências pode ser observada desde as primeiras viagens de que se tem registro, há na viagem uma estrutura recorrente, existe sempre: uma origem, um destino, um itinerário, um encontro e um retorno. Por mais diversificados que esses momentos possam se apresentar, essa é a estrutura básica, e através dela é possível mapear viagens distintas e verificar como se relacionam.

A viagem se vincula sempre a uma questão de deslocamento, temos uma origem, que constitui o ponto de partida, a origem é associada ao espaço daquilo que é herdado, da identidade, mundo seguro e conhecido do sujeito. 0 destino, é seu contrário e, por analogia, associa-se a um espaço que é diverso do seu. 0 espaço do destino é desconhecido, estrangeiro, é o que se busca conhecer, compreender ou incorporar.

Entre origem e destino, entre esses dois conceitos que podem ser vinculados diretamente ao espaço, se associa o itinerário. Este pode ser mais ou menos definido, mais ou menos programado e faz parte das estruturas recorrentes identificadas na maioria das viagens. 0 itinerário diz muito sobre os aspectos lógicos, racionais, e mentais da viagem, o itinerário liga os conceitos de origem e destino, prevê a duração da viagem, pré-seleciona lugares para se visitar, calcula rotas, é um a priori, e pode ser mais ou menos determinado.

O itinerário ainda considera os aspectos abstratos, não concretos, dos espaços de origem e destino. 0 espaço de origem, por exemplo, nos traz indícios de quem é esse viajante, de onde vem e o mundo cultural ao qual pertence. 
Sobre o território destino, o itinerário nos fornece indícios das expectativas desse viajante sobre o desconhecido, os tempos que serão dedicados a cada etapa e os meios pelos quais ele planeja confrontar esse espaço.

Além do itinerário, uma outra etapa dessas estruturas da viagem que estamos explorando é o encontro, etapa que relaciona novamente origem e destino. É o acontecimento em tempo real da viagem, que se aproxima da realização do itinerário, mas permite uma maior abertura e traz o tema da imprevisibilidade. Se por um lado, o itinerário é uma etapa mental, racionalmente elaborada, o encontro seria a etapa sensível, corpórea, fenomenológica da viagem, etapa que sugere imprevistos, surpresas, eventos e possibilidades para além do itinerário. 0 encontro então é próximo à ideia de percurso, e liga origem e destino pela via sensível.

A última etapa comum as viagem seria então o retorno, ou a finalização da viagem. Quando se completa o itinerário e as possibilidades de encontro, o retorno é a síntese, finda a viagem e se transforma em uma espécie de revisão do que foi o previsto e o imprevisível da trajetória.

Quando do momento do retorno, o sentido de origem e a ideia a priori do destino se transformam, o itinerário é revisto, e a etapa que ainda é possível de ser considerada é novamente o encontro, a lembrança da viagem, o encontro com o próprio sujeito da viagem transformado.

Alguns autores falam dos momentos da viagem, discutem essas estruturas segundo suas categorias, como por exemplo, Amoroso Lima ${ }^{1}$, quando define quatro momentos da psicologia das viagens: a preparação, a realização, a volta e a evocação, todas elas revestidas de carga emocional. Para ele, o imprevisto e a incerteza fazem dos dois primeiros momentos, situações especiais, fala mesmo que o gosto pelo desconhecido é uma fala de esperança, mais subjetiva que a própria concretização da viagem. Discute ainda a importância e as particularidades da evocação posterior à viagem, o da construção de narrativas em comparação com os registros produzidos in loco, a dimensão de anotações ou síntese, de euforia, reflexão.

0 estudo da viagem trata assim da própria transformação que ela provoca no sujeito que, cumprindo seu percurso vê ainda transformarem-se, as concepção iniciais de origem, destino, e suas derivações que também são revistas e transformadas.

Mas essa é outra história, da qual fizeram parte muitos personagens e

1 Alceu de Amoroso Lima foi um escritor, pensador e crítico literário brasileiro em 1920. 
cenários. 0 que importa nessa consideração é o que se observa nessas distintas viagens, em várias épocas, o que há de constante e essencial na prática das viagens. A hipótese que defendemos é que aquilo que está na essência é o tema da transformação, possível de ser verificada em todas as viagens, na medida em que as experiências que se dão nas viagens são mais dilatadas, provocando no viajante, reflexões de toda ordem, o aprendizado se dá no território desconhecido, na paisagem, no clima, na cultura.

Podemos recorrer a um poema de Carlos Drummond para salientar esse tema da transformação do sujeito, e atentar ao fato de que o viajante que retorna nunca é o mesmo que foi, que é extremo e modificador o processo que se estabelece ao longo de toda viagem, e esse talvez seja o ponto fundamental da viagem, provocar metamorfoses, dissolver antigas identidades em um novo meio, espaço, contexto, a fim de ir constituindo um novo sujeito.

Quando vim da minha terra, se é que vim da minha terra (não estou morto por lá?), a correnteza do rio me sussurrou vagamente que eu havia de quedar lá donde me despedia. Os morros, empalidecidos no entrecerrar-se da tarde, pareciam me dizer

que não se pode voltar, porque tudo é conseqüência de um certo nascer ali. Quando vim, se é que vim de algum para outro lugar, o mundo girava, alheio à minha baça pessoa, e no seu giro entrevi que não se vai nem se volta de sítio algum a nenhum. Que carregamos as coisas, moldura da nossa vida, rígida cerca de arame, na mais anônima célula, e um chão, um riso, uma voz ressoam incessantemente 
em nossas fundas paredes.

Novas coisas sucedendo-se

iludem a nossa fome

de primitivo alimento.

As descobertas são máscaras

do mais obscuro real,

essa ferida alastrada

na pele de nossas almas.

\section{Quando vim da minha terra}

não vim, perdi-me no espaço,

na ilusão de ter saído.

Ai de mim, nunca saí.

Lá estou eu, enterrado

por baixo de falas mansas,

por baixo de negras sombras,

por baixo de lavras de ouro,

por baixo de gerações,

por baixo, eu sei, de mim mesmo,

este vivente enganado,

enganoso. ${ }^{2}$ (ANDRADE, 2002)

Como fala o poema, o sítio ao qual se volta também já não é o mesmo, o sujeito se transforma e a percepção que ele passa a ter de um antigo sítio com o qual ele se identificava também se transforma. Como na citação de Ianni:

Na medida em que viaja, o viajante se desenraíza, solta, liberta. Pode lançar-se pelos caminhos e pela imaginação, atravessar fronteiras e dissolver barreiras, inventar diferenças e imaginar similaridades. A sua imaginação voa longe, defronta-se com o desconhecido, que pode ser exótico, surpreendente, maravilhoso, ou insólito, absurdo, terrificante. Tanto se perde como se encontra, ao mesmo tempo que se reafirma e modifica. No curso da viagem há sempre alguma transfiguração, de tal modo que aquele que parte não é nunca o mesmo que regressa. (IANNI, 1996)

A cada viagem, perde-se um pouco da antiga identidade que significava uma origem e até uma ideia do que seria o espaço do destino. Dessa forma, a identidade primeira é dissolvida, e, a partir do encontro que a viagem, a migração possibilita, outras identidades culturais são absorvidas, criando um sujeito transformado, assim como fica transformado também o olhar sobre o antigo sítio.

2 Poema de Carlos Drummond de Andrade, reunido em Farewell, 8.ed. 
A terra, o sítio do qual se sai pode ser lido como alegoria do sujeito que se é, das memórias que se tem, das experiências que teve até agora.

A viagem no sentido em que tratamos aqui, não é compreendida por uma mera mudança de lugar. Nesse sentido:

A viagem aparece quando as condições econômicas e sociais permitem ao indivíduo romper com o seu meio. Ela nasce com a riqueza, a segurança das estradas, a curiosidade e o tédio: nas classes superiores dos povos mais civilizados.(PIMENTEL, 2001)

Com essa citação compreendemos as características econômicas e sociais que possibilitaram o aparecimento do sentido do termo "viagem" como é explorado, nesse trabalho, tem o sentido de busca, de motivação e não de consequência, fatalidade, orientadas por fatores que não são externos ao sujeito.

Assim a viagem pode ser entendida, nesse novo sentido agregado ao termo, como possibilidade de autonomia, como expressão de individualidade, sendo que a sua realização voluntariosa está presente já desde as viagens medievais, como aponta Leed:

Conforme sugere Leed, o elemento definidor das viagens dos cavaleiros medievais era já ostensivamente voluntário e sem nenhum propósito utilitário; as viagens dos cavaleiros, que são o padrão e o modelo para o significado das viagens modernas, são essencialmente auto-referenciadas, celebradas para revelar o caráter essencial do cavaleiro como 'livre', outrora a essência da nobreza, mas desde o século XVII considerado um atributo da natureza humana. Se jornada heróica antigamente, a viagem é hoje uma opção. Produto da livre escolha, oportunidade de demonstração de uma identidade, de busca da liberdade, da autoexibição ou do auto-conhecimento, a viagem, nas circunstâncias modernas, significa autonomia e forma de acesso a um novo mundo material e objetivo. Voluntarismo, liberdade e prazer são as características essenciais da moderna concepção de viagem. (PIMENTEL, 2001)

"Auto-referência", "liberdade", "voluntarismo", são termos usados por Leed para situar o sentido que viagem passou a ter a partir das expedições medievais, sentido esse que serviu de base para o significado das viagens modernas.

Esses três termos podem ser discutidos no contexto de sua inserção histórica, Leed em seu ensaio "La mente del viaggiatore" aponta que a viagem, 
como a estamos explorando, está ligada ao conceito de ciência, de objetividade que visava explorar e aprender o mundo, que tomou força com o advento do Renascimento.

$\mathrm{Na}$ primeira parte desse livro, o autor descreve as estruturas da viagem como: 1."partire"; 2."transitare"; 3."arrivare" e por último, "l'erotismo dell'arrivo".

$\mathrm{Na}$ segunda parte, intitulada "a viagem filosófica", separa em três momentos: 1.tradição antiga e medieval; 2.a viagem renascentista; 3.a viagem científica.

Como faz em seu ensaio, Leed é um dos autores que entende a viagem como uma sequência de eventos estruturados, em que cada uma das partes conserva características próprias. Depois de intitular as partes, coloca-as como comuns à vários tipos de viagem, identificadas por ele como a viagem da tradição antiga, em um segundo momento a viagem renascentista e por último a viagem científica.

Por último, na terceira parte o autor discute "viagem e identidade", também a partir de três sessões: 1.a viagem e a transformação do indivíduo; 2.a sociedade viajante; 3.viagem e história.

Nesse momento, o autor aproxima os conceitos de viagem e identidade, lado a lado, e os lê a partir dessas três chaves, a do indivíduo, a da sociedade e a da história.

Podemos pensar a prática da viagem também sob a perspectiva de Judith Adler $^{3}$, que considera a experiência da viagem em seus variados estilos de viajar, abarcando itinerários, instrumentos de registro, durações, motivações próprias de cada contexto histórico. Para ela, o ato de deslocar-se sobre um território configura uma "arte de viajar", como um processo próprio do corpo do viajante, num processo perceptivo que é histórico-social, mas também é particular, subjetivo.

Existem "estilos" de viajar, os quais se modificam em relação à sociedade e ao tempo em que se constituem. Sem perder essa dimensão sócio-histórica do deslocamento, a noção de estilo remete àquilo que há de particular no ser, trata-se de uma maneira de estar em situação. (ANDRIOLO, 2011, p.115)

Através do pensamento fenomenológico de Merleau-Ponty é possível compreender a natureza do conhecimento que é produzido e absorvido em viagem, aprendizado de natureza sensível e aberta, em que a percepção é o 3 Conceito desenvolvido por Judith Adler em Origins of sightseeing. Adler é pesquisadora da Brandeis University. 
instrumento principal. "A percepção de um mundo cultural é dada pelas coisas que carregam a existência anônima de outros humanos."(ANDRIOLO, 2011, p.124)

A identidade de origem do viajante é importante, na medida em que: "a civilização da qual eu participo existe para mim com evidência nos utensílios que ela fornece." (MERLEAU-PONTY, 1999, p.465)

A viagem tem como essência o encontro com o estrangeiro, com o desconforto, que move o sujeito no sentido da busca pela compreensão, que só é possível mediada pela percepção.

Nesse sentido, a compreensão da atividade do olhar, ligada a percepção se faz importante. A via de análise usada pela abordagem da pesquisa se dá no campo da fenomenologia, no entendimento de Merleau-Ponty, na qual o corpo é protagonista, o corpo, que carrega consigo a potência do conhecimento pelos sentidos, a percepção.

Viajar torna-se um exercício de ver, movimento de investigação e compreensão. 0 estrangeiro, o viajante, o voyeur constituem uma imagerie, na qual o sujeito se dá a conhecer, viajando. Nessa "mínima odisséia" entretanto, o mundo do viajante não se estreita, antes abre-se; não se bloqueia, mas faz experimentar a vertigem das alterações temporais. (OLIVEIRA, 1995)

Sérgio Cardoso, em seu texto: "O olhar viajante" explica o conceito de "mundo cultural", que é definido pelas origens, pela identidade do viajante, que implica na forma em que o desconhecido é apreendido no percurso da viagem. 0 aprendizado da viagem penetra então pelos vãos do próprio mundo do viajante.

Se o viajante fura o horizonte da proximidade e transpõe os limites de seu mundo para fixar a atenção mais além - no que não se deixa ver mas apenas adivinhar ou entrever —, é sempre pelos vãos do próprio mundo que ele penetra, na medida em que surgem brechas na sua evidência, abrindo passagens na paisagem ou contornando desníveis e vazios. (CARDOSO, 1988, p.358)

Outro conceito importante para pensar a natureza do aprendizado em viagem é o de estranhamento, esse sentimento acontece na etapa da viagem caracterizada pelo encontro. Encontro esse que pode ser um confronto, entre a identidade, entre o mundo-cultural de origem do viajante e o mundo estranho, estrangeiro, desconhecido do território destino.

$\mathrm{Na}$ viagem, instaura-se um paradoxo na percepção porque o observador não reconhece os objetos inteiramente como seus, ou de sua civilização, o estranhamento provém de outro tempo 
e também de outras pessoas. Pode-se, como quer o filósofo, reconhecer uma civilização estranha nas ruínas ou nos restos de instrumentos vistos sobre a paisagem, porque por meio deles se percebe um ato humano, um outro homem ou mulher. (ANDRIOLO, 2011, p.124)

Essas discussões nos levam a pensar a viagem enquanto possibilidade de aprendizado, aproximando sua prática da disciplina, ao mesmo tempo em que conserva um elemento importante de imprevisibilidade inerente a sua dinâmica.

O interesse dessa análise é demonstrar exemplos de como as viagens foram amplamente utilizadas como ferramenta formação de estudantes, pesquisadores, artistas pela via da disciplina que essa prática constituiu.

Podemos entender disciplina como um conjunto de regras ligadas à instrução de pessoas em vários níveis, o conceito de disciplina engloba observância, princípio, organização, aprendizado, e é por essa via que aproximamos as estruturas recorrentes da viagem do conceito de disciplina.

A disciplina pode ser pensada como um jogo delimitado, como descrito por Foucault em seu texto: "A ordem do discurso", mas há mais mesmo nesse sistema, o componente da imprevisibilidade, já que os conjuntos disciplinares não contêm todas as verdades sobre um campo de conhecimento. Assim, essa reflexão pode ser feita sobre as viagens, consideradas um campo de conhecimento, que é disciplinar, sistemático, mas onde sempre há a possibilidade de se formular novas proposições.

Será necessário também reconhecer naquilo a que se chama as "disciplinas" — não as ciências - um outro princípio de limitação. Princípio esse também relativo e móvel. Princípio que permite construir, mas com base num jogo delimitado. A organização das disciplinas opõe-se tanto ao princípio do comentário quanto ao do autor. Ao do autor, uma vez que uma disciplina se define por um domínio de objectos, um conjunto de métodos, um corpo de proposições consideradas verdadeiras, um jogo de regras e de definições, de técnicas e de instrumentos : tudo isto constitui uma espécie de sistema anónimo à disposição de quem quer ou pode servir-se dele, sem que o seu sentido ou a sua validade estejam ligados ao seu inventor. (FOUCAULT, 1971)

Ao entender a viagem como um sistema disciplinar, compreende-se que dentro dele, como explicou Foucualt, há mais que regras e estruturas delimitadas, mas há possibilidade de se formular enunciados, a partir de uma 
base.

Mas o princípio da disciplina opõe-se também ao do comentário : numa disciplina, diferentemente do comentário, não está suposto à partida que é um sentido o que deve ser redescoberto, nem está suposto que é uma identidade que deve ser repetida ; está suposto antes aquilo que é necessário para a construção de novos enunciados. Para que haja disciplina, é preciso, por conseguinte, que haja a possibilidade de formular, e de formular indefinidamente, novas proposições. (FOUCAULT, 1971)

Mas há mais ; e há mais, sem dúvida, para que haja menos : uma disciplina não é a soma de tudo aquilo que pode ser dito de verdadeiro a propósito de qualquer coisa ; nem mesmo é o conjunto de tudo aquilo que, a propósito de um mesmo dado, pode, pelo princípio de coerência ou sistematização, ser aceite. A medicina não é constituída pela totalidade do que se pode dizer de verdadeiro sobre a doença ; a botânica não pode ser definida pela soma de todas as verdades que dizem respeito às plantas. Há duas razões para isso : em primeiro lugar, a botânica ou a medicina, como qualquer outra disciplina, são feitas tanto de erros quanto de verdades, erros que não são resíduos ou corpos estranhos, mas que têm funções positivas, uma eficácia histórica, um papel muitas vezes indistinto do das verdades. (FOUCAULT, 1971)

Essa capacidade de formular enunciados diversos dentro de uma disciplina pode ser associado a prática da viagem de inventar itinerários, por exemplo, formas de percorrer a viagem distintas, em épocas.

No interior dos seus limites, cada disciplina reconhece proposições verdadeiras e falsas ; mas repele para o outro lado das suas margens toda uma teratologia do saber. 0 exterior de uma ciência está mais e menos povoado do que julgamos : certamente que há a experiência imediata, os temas imaginários que trazem e reconduzem incessantemente crenças sem memória ; mas talvez não haja erros em sentido estrito, porque o erro não pode surgir e ser avaliado senão no interior de uma prática definida ; em contrapartida, há monstros que circulam e cuja forma muda com a história do saber. (FOUCAULT, 1971)

Uma disciplina tem o rigor de considerar dentro do campo disciplinar teorias, proposições que passem por um mesmo procedimento, um método, um sistema, um conjunto de estruturas, mas o objeto sobre o qual se fala, é sempre novo, pode ser sempre inventado. 
Numa palavra, uma proposição tem de passar por complexas e pesadas exigências para poder pertencer ao conjunto de uma disciplina; antes de se poder dizê-la verdadeira ou falsa, ela deve estar, como diria Canguilhem, "no verdadeiro". (FOUCAULT, 1971)

Essa aproximação conta uma história das viagens como parte da história da formação de sujeitos, formação essa que é lida como instrução, aprendizado, que se dá por meio das estruturas recorrentes em viagem.

Compreende-se a associação das estruturas da viagem ao conceito de disciplina a partir de um reconhecimento dos itinerários, entendendo esse tópico como o projeto da viagem, suas motivações, desde os itinerários clássicos até as transformações de mentalidade, de contextos históricos e culturais que ampliaram os endereços das viagens, o interesse romântico pelo exótico, pelo pitoresco, as interpretações modernas acerca dos destinos fora do ocidente ou mesmo por regiões com tradições populares dentro de suas próprias fronteiras nacionais.

Se pela descrição do conceito de itinerários e suas decorrências o associamos à dinâmica da disciplina, o percurso das viagem engloba imprevistos, surpresas, erros, e esses são igualmente importantes para que essa experiência de deslocamento gere aprendizado, transformação no sujeito que viaja.

Ao considerar a experiência da viagem como uma experiência de aprendizado, o elemento da imprevisibilidade também deve ser considerado no estudo da viagem enquanto possibilidade de formação, esse é um componente criativo desse processo.

Ao entender a lógica dos procedimentos e estruturas próprias da viagem de formação, adquirem-se meios para analisar as transformações que a disciplina vem sofrendo, assim como entender algumas motivações comuns, que perpassam a história de uma época ou de outra.

A viagem como formação, opera pelas ferramentas, estruturas, que são possíveis dentro do campo disciplinar, e dentro desse mesmo sistema, na possibilidade do imprevisível.

\section{_"Grand tours"}

Os "grand tours" foram as tradicionais viagens percorridas por jovens de classe média-alta para os destinos icônicos da Europa, iniciando na Inglaterra, esses jovens partiam rumo à França, Itália. Depois dos aristocratas ingleses, 
viajantes vindos de muitas partes do mundo realizaram a viagem, que pode ser identificada como uma prática que buscava tomar contato, na qual os viajantes eram expostos ao legado cultural tanto da Antiguidade Clássica quanto do Renascimento. A prática teve início por volta de 1600 e continuou inclusive se intensificando após as facilidades de mobilidade que surgiram como o tráfego ferroviário em uma escala maior, até os anos de 1840.

Antes de essa prática chegar a viajantes de outros países, o fenômeno do "grand tour" foi essencialmente inglês, como justifica Valéria Salgueiro, essa nação contava, naquele momento, com as condições econômicas propícias para o florescimento dessa prática.

O fenômeno do Grand Tour foi, contudo, acima de tudo inglês, e isto se explica pelas circunstâncias vividas por aquela nação à época: a Inglaterra havia triunfado na Índia e na América do Norte, e era a nação que estava liderando o mundo no comércio e nos métodos industriais e agrícolas de produção. Grupos nacionais, direta ou indiretamente se beneficiavam da geração de riqueza no próprio país e por todo o mundo sob seu controle, o que fazia aumentar, mais do que em qualquer momento anterior, o dinheiro para gastar com o prazer. (SALGUEIRO, 2002)

Posteriormente, com o alargamento da escala dos meios de transporte, partir em "grand tour" chegou à muitos países, inclusive ao Brasil, onde os filhos dos mais ricos buscavam pela mesma formação dos europeus.

Verificou-se, então, um aumento do interesse nesse tipo de viagem:

Mas, aos poucos, essa clientela foi se ampliando, de modo que, ao final do século 18, o Grand Tour estava já firmemente estabelecido para os filhos da classe média urbana melhor situada, formada por burgueses prósperos e emergentes do setor de serviços que a indústria indiretamente engendrava. (SALGUEIRO, 2002)

Valéria Salgueiro, em seu texto: "Grand Tour: uma contribuição à historia do viajar por prazer e por amor à cultura.", cita alguns viajantes que fizeram do modelo e do formato do "grand tour" sua prática de formação como três notáveis "grand tourists": o novelista britânico Thobias Smollet, o poeta alemão Johann W. von Goethe e o especialista inglês em antigüidades Richard Payne Knight.

Nesse momento surge um novo viajante, com características que descrevem um tipo de turista, um tipo que vem se diferenciar de outros viajantes, como os viajantes das navegações, dos nômades, dos conquistadores, dos missionários religiosos. 
Um novo tipo de viajante surge no século 18 em conexão com as transformações econômicas e culturais na Europa do Iluminismo e da Revolução Industrial. Trata-se aqui não do viajante de expedições de guerras e conquistas, não do missionário ou do peregrino, e nem do estudioso ou cientista natural, ou do diplomata em missão oficial, mas sim do grand tourist, conforme era chamado o viajante amante da cultura dos antigos e de seus monumentos, com um gosto exacerbado por ruínas que beirava a obsessão e uma inclinação inusitada para contemplar paisagens com seu olhar armado no enquadramento de amplas vistas panorâmicas, compostas segundo um idioma permeado por valores estéticos sublimes. Um viajante dispondo acima de tudo de recursos e tempo nas primeiras viagens registradas pela historiografia da prática social de viajar por puro prazer e por amor à cultura. (SALGUEIRO, 2002)

Esse era o típico "grand tourist", um viajante que se identificava com alguns padrões, econômicos, culturais, e mesmo de tempo. Além dessa característica, esse turista tinha uma curiosidade em relação ao passado, e uma vontade de aprender com ele, com suas ruínas.

O modo como esses primeiros turistas planejaram e viveram suas viagens gerou um padrão que viria a ser seguido por outros nobres, aspirantes a viajantes, artistas, escritores que queriam passar pelo mesmo processo de formação, por considera-lo adequado, enobrecedor até.

Esse padrão veio a partir dos destinos escolhidos para se visitar, o tempo que se demandava em cada localização, a forma de viajar, os guias para se ler antes de partir, a presença de um mestre, e até a imitação do modo de fazer os relatos, os registros gráficos da viagem, das paisagens.

As viagens nesse modelo de "grand tour" tinham sempre longas durações, podendo durar de meses até anos, outra característica dessa prática é a presença de um mestre, ou tutor, que acompanhava o estudante, pintor, arquiteto em formação, esse tutor já tinha um conhecimento prévio sobre o local visitado.

O fato de essas viagens terem sempre longas durações promoveu, nos viajantes, uma exposição prolongada dos hábitos culturais dos países visitados, um estranhamento e uma identidade, o tempo do estranhamento, de perceber as diferenças de onde se vinha no confronto com o estrangeiro, e da mesma forma, a percepção de identidades, ou nesse caso, a necessidade, o desejo de se formar a partir da lição da qual a cultura clássica e renascentista falava, 
os edifícios, as paisagens. De certa forma, esses viajantes estudantes previam, tinham um anseio por uma transformação de viagem nesse sentido.

As rotas de viagem apresentavam problemas específicos, as distâncias percorridas eram longas, por exemplo:

Se considerarmos as dificuldades envolvidas na viagem devido às precárias condições de superação da distância entre os lugares, chegar até Roma no século 18 era uma façanha absolutamente corajosa. Para os que partiam da Inglaterra, o cruzamento do Canal da Mancha constituía parte realmente crítica da viagem. Ventos, ondas altas e cais precários tornavam o embarque e o desembarque uma aventura aterrorizante, acompanhada por náuseas, vômitos, sustos e até ferimentos na troca de embarcações maiores por barcos menores, necessários em vista de ancoradouros inadequados para as embarcações de maior porte. Não havia ainda o navio a vapor no século 18 , sendo a travessia do Canal da Mancha feita ainda por embarcações à vela - uma aventura verdadeiramente apavorante para muitos que pela primeira vez em suas vidas estavam vendo o mar e, simultaneamente, tendo de enfrentá-lo. (SALGUEIRO, 2002)

Dessa forma, para todo viajante que se aventurava por um "grand tour", as condições de transporte, estradas, climáticas, era um desafio a ser superado entre as distâncias de origem e destino das viagens.

Nos percursos, havia algumas possibilidades de rotas, das quais as mais usadas:

Até chegar a Roma, essencialmente o destino final do itinerário do "grand tour":

Como destino privilegiado na Idade Clássica, a Itália foi contemplada em muitos registros e impressões de viajantes. (...) As cidades mais visitadas eram Veneza, Florença, Roma e Nápoles. (ANDRIOLO, 2011, p.17)

Considerando a Europa, uma diversidade de destinos era possível, mas todos eles selecionados para os "tours" conservavam uma ambiência em comum, que era buscada pelos viajantes, a do contato in loco com ícones da história antiga do continente, impressa nos edifícios ou ruínas desses.

Meios de transporte típicos de cada região, por exemplo, barcos, gôndolas. E algumas condições bastante difíceis, longos trajetos, transporte por animais em vários tipos de carruagens, percursos acidentados.

A força do vapor aplicada aos meios de transporte iniciou-se apenas em torno de 1780, com a construção dos primeiros barcos 
experimentais na França, nos Estados Unidos e na Escócia, sendo que até o advento desse tipo de força motriz e emprego do ferro no casco, as embarcações eram em madeira, sendo o choque contra rochedos fatal para sua integridade. (SALGUEIRO, 2002)

Como nos descreve Andrioloㄴ, na etapa de preparação para essas viagens, era comum a leitura de guias, publicações acerca das cidades em que se ia visitar antes da partida, alguns dos títulos mais importantes foram, "Maravilhas da cidade de Roma", que já circulava desde a Idade Média, com muitas reedições, que iam sendo completadas com informações que seriam úteis aos viajantes, outro era o guia de Veneza, escrito Francesco Sansovino em 1558, ainda sobre Veneza outra publicação era o "Guia para estrangeiros”, de Vicenzo Coronelli.

"História da arte na Antigüidade" (1764), de Joachin Winckelmann também foi um título muito lido como preparação para os viajantes que direcionavam seus itinerários a Roma.

Exemplo também desses guias e tratados que serviam como elementos preparatórios e eram lidos nas etapas anteriores à viagem propriamente dita, temos o tratado do arquiteto italiano Andrea Palladio (1508-1580 ${ }^{5}$ que expondo seus próprios projetos em desenho, permitia aos futuros viajantes, a referencia anterior ao confronto com o edificado.. 0 alemão Goethe foi um dos notáveis viajantes que fez uso dessa referência. Essa era uma forma de antecipar o conhecimento da viagem, familiarizando-se com os edifícios, os monumentos que iria ter contato.

Valéria Salgado também demonstra como os próprios relatos de viagem de quem já retornou de um "grand tour" foram se transformando em guias para orientar novas viagens:

Relatos de viagem e coleções de vistas de lugares constituíam as formas usuais de guias impressos para o Grand Tour, e era com essas formas embrionárias de guias que o viajante se munia para se informar e aproveitar o máximo da viagem. Em meados do século 18 existiam já diversos guias impressos tendo como preocupação orientar o viajante na visita a locais célebres e antigüidades de Roma. Algumas leituras constituíam parte da preparação para a viagem, entre as quais tratados e obras célebres de autores antigos e renascentistas influentes nas artes e na arquitetura. (SALGUEIRO, 2002)

4 ANDRIOLO, Arley. Metamorfose do olhar na viagem de Goethe à Itália. Art Cultura, Uberlândia, v.13, n 23, jul-dez 2011, pp.117.

5 "I Quattro Libri dell'architettura" de A. Palladio, arquiteto e tratadista italiano no século XVI. 
Mas não só as leituras de referência como guias, tratados e até mesmo os relatos de outros viajantes foram usadas nesse momento anterior ao da partida do novo turista; uma rede de conhecimentos de apoio, contatos, cartas de apresentação e recomendação faziam parte da bagagem a ser preparada:

Além das leituras, uma rede de conhecimentos, apoiada em comerciantes, banqueiros, diplomatas, artistas e estudiosos, facilitava a viagem do grand tourist. Através dessas redes estruturadas em posições e relações pessoais, e acionadas através de cartas de apresentação, cartas de recomendação, salvoscondutos e bilhetes de amigos e conhecidos, facilidades eram conseguidas como reservas em hospedarias, além de contatos com tipos locais, para servirem como guias, ou com connoisseurs, para que estes abrissem suas coleções particulares de antigüidades à inspeção do viajante. (SALGUEIRO, 2002)

A experiência dos "grand tours" corresponde ao início histórico do turismo como o conhecemos contemporâneamente, e nessa experiência começamos também a identificar que o acontecimento da viagem se consubstancia como uma prática educativa e processo de instrução.

Dos relatos de viagens, é possível extrair informações importantes sobre a época em que essas viagens aconteceram e as condições em que essas viagens se deram:

Com observação de seus relatos procuramos olhar para as principais motivações das viagens de Grand Tour, destacando aspectos relevantes da nada fácil empreitada de viajar na Europa continental do século 18, quando se tinha de vencer grandes distâncias por áreas acidentadas no lombo de mulas, numa época que ainda desconhecia a navegação marítima a vapor e o trem de ferro. Entre os aspectos abordados no trabalho, destacamse o gosto pela arte e arquitetura dos antigos, o culto à ruína e a valores estéticos sublimes na contemplação da paisagem que acompanhavam o Grand Tour - ou Grand Voyage, ou Grosse Reise , a partir dos quais podemos distinguir a emergência de uma visualidade dessa experiência de viagem dita "clássica", distinta daquela engendrada pelo olhar romântico do século 19 e da que vem se configurando pelo olhar contemporâneo, cheio de tecnologias. (SALGUEIRO, 2002)

Essas informações nos dão condições de discutir sobre o pensamento corrente na época, como se dava a experiência de aprendizado, quais eram as crenças nessa prática, entre outras nuances que caracterizavam um olhar 
típico dos viajantes de "grand tour".

A partir dessa consideração, Andriolo sustenta que os relatos e o conhecimento da experiência da viagem por um viajante, depende da compreensão do corpo em situação histórica. A compreensão do corpo passa pelo conhecimento fenomenológico da questão, pela percepção, que vai formulando visões de mundo.

Frente ao problema da experiência da viagem, o processo de significação do espaço, do outro e do eu, depende da compreensão do corpo em situação histórica. (ANDRIOLO, 2011, p.115)

0 que se extrai da experiência dos viajantes acumulada em seus relatos, é parte social, ambiental, histórica, inundada de uma percepção individual. É como se dentro da disciplina "viagem", fossem formuladas e possíveis muitas formas de aprender, experienciar e comunicar a viagem através dos seus relatos.

Essa é a percepção já apontada por Goethe em seus registros, ele nos diz de como a viagem opera na sua forma de conhecer o mundo, nesse caso, a viagem proporcionando um conhecimento sobre si mesmo. Em setembro de 1786 ele anota: "Não estou fazendo esta viagem maravilhosa com o propósito de me iludir, mas sim de me conhecer melhor a partir dos objetos que vejo." (GOETHE, 1999, p.115)

Andriolo discute os registros da viagem de Goethe como uma exploração da linguagem, como se a viagem representasse o emergir de uma nova visão de mundo por parte do viajante; a exploração da linguagem consistia na fusão entre ver, olhar, pesquisar, escrever e desenhar, num esforço de representar o todo da experiência da viagem.

A multiplicidade das linguagens utilizadas na representação se relaciona com a natureza da experiência da viagem, que é intensa, cheia de estímulos, novidades. Sobre a viagem a Roma, Goethe registrou:

[...]durante uma viagem, aprende-se o que se pode pelo caminho; cada dia nos traz algo de novo, e apressamo-nos em refletir e opinar a respeito. Aqui, porém, está-se numa escola muito grande, na qual cada dia tem tanto a ensinar que sequer nos é permitido ousar dizer algo acerca do que aprendemos no seu decorrer. $\mathrm{Na}$ verdade, faríamos bem em, mesmo passando anos aqui, observar um silêncio pitagórico. (GOETHE, 1999, p.155)

A partir da interpretação da viagem de Goethe, Andriolo discute de que maneira o campo perceptivo da viagem é amplo e abrange uma decisão que é estética, e conclui: 
Compreende-se porque ver não é olhar; pois olhar é viajar. A visão da paisagem suscita o senso poético, asseverou Goethe. A experiência descrita na narrativa de sua viagem coloca em relação quatro elementos constituintes da experiência da viagem: o espaço, o outro, o eu, o tempo. Se por um lado, o campo perceptivo é preenchido pelos usos sociais, econômicos e políticos dos objetos, por outro, está aberto à experiência que se poderia então designar estética. Se, ver não é olhar e olhar é viajar, o olhar viajante prolonga-se no campo perceptivo como experiência estética porque realiza o objeto estético em outro nível de significação. (ANDRIOLO, 2011, p.127)

Na discussão de Andriolo, a partir da viagem de Goethe e a utilização extensa da linguagem, sobre o que os relatos produzidos pelos viajantes de "grand tours" nos deixaram, é possível apontar para uma caracterização do olhar típicos desses viajantes, da filosofia corrente na época:

0 viajante de "grand tour" é aquele que viaja com muitas instruções, planeja seu itinerário a partir delas, observa a partir delas e a representa também a partir de modelos. Construímos um perfil desse viajante a partir das descrições e da representação visual que era feita dos monumentos, por exemplo, o tipo do desenho que era corrente, as referências e guias que foram utilizados.

No culto ao antigo característico do século 18 a viagem desempenhou um papel muito importante no reconhecimento, assim como na descrição e representação visual de monumentos. Pode-se dizer que foi com os Grand Tours que se iniciaram os estudos sistemáticos da ainda embrionária ciência da arqueologia e as primeiras teorizações modernas sobre conservação/ preservação de monumentos históricos, questão que tem atraído tantos debates desde Ruskin e Violet-le-Duc. Sob o olhar de viajantes que viam no estudo dos antigos o sentido maior de sua viagem, monumentos puderam ser localizados, identificados e estudados, para serem por fim tornados conhecidos do público em obras ilustradas e pioneiras de arqueologia e de história da arte e da arquitetura. (SALGUEIRO, 2002)

Alguns eventos importantes começam a ser compreendidos, como por exemplo, a dimensão embrionária dos estudos de patrimônio, preservação, estudos arqueológicos que aparecem em muitos dos registros deixados por esses viajantes. Os desenhos ainda tiveram utilidade na identificação de alguns monumentos, edificações, e amplamente usados como fonte de estudos, 
pesquisas, por historiadores e outros até hoje.

0 culto ao antigo que acompanhou o Grand Tour à Itália também não se esgotava na viagem, tendo desdobramentos posteriores à chegada dos viajantes a seus países, especialmente na Inglaterra, onde eles eram em maior número e mais ativos. Um desses desdobramentos foi a fundação de sociedades reunindo pessoas com interesse em antigüidades. A Society of Dilettanti, fundada em 1734 por um grupo de gentlemen que havia viajado em um tour à Itália, tinha como preocupação central promover a investigação e a publicação dos resquícios das grandes civilizações do passado. Além de conceder bolsas para viagem de estudos e pesquisas sobre antigüidades na Itália, a Society of Dilettanti publicava obras sobre o assunto como, por exemplo, a Antiquities of Athens (1762), de James Stuart e Nicholas Revett. (SALGUEIRO, 2002)

Os diários e desenhos produzidos tinham esse potencial de se constituir em uma publicação, de ser parte de uma compilação que viesse a auxiliar nos futuros estudos, pesquisas arqueológicas, históricas; assim como para outros viajantes.

O objetivo do Grand Tour de ampliar o conhecimento sobre a história e a arte dos antigos, um hábito aristocrático e altamente em moda, pressupunha a elaboração de um diário de viagem, e, se possível, a ilustração dos monumentos observados. A escrita do diário e a ilustração faziam parte de um ritual metodológico que ia se impondo, cujo ponto alto era a sua publicação, ao retorno do viajante, o que ampliava o conhecimento e despertava o interesse dos leitores para novos projetos de viagem e novos conhecimentos. A publicação conferia também bastante prestígio ao autor, que procurava referir-se a passagens históricas e a textos da literatura clássica para estabelecer relações com o que era visto no ato da viagem, pois isso denotava um saber em moda e compartilhado com o público leitor. (SALGUEIRO, 2002)

Como o estudo do passado, desde a verificação das ruínas alimentava a imaginação dos viajantes, um pouco como vai acontecer nas viagens modernas, principalmente no campo da arquitetura:

Ruínas são sinais visíveis do passado, de um tempo que se foi, deixando lições para o presente e o futuro. Para o grand tourist, a Itália era, nesse sentido, extremamente estimulante: as ruínas de seus monumentos antigos instruíam e ao mesmo tempo alimentavam a imaginação do viajante, fornecendo-lhe "matéria" 
para a descrição e o estudo, bem como para alimentar a fantasia.

(SALGUEIRO, 2002)

Os registros eram profundamente marcados pelo emprego da pintura, como um ritual metodológico, de representação, a paisagem era uma forma de representar que continha muitos detalhes, informações, referências sobre a atmosfera observada em viagem.

O temário dessa produção artística relacionada ao Grand Tour era formado predominantemente por paisagens panorâmicas ou fragmentos (recortes) de paisagens com algum acidente físico de especial interesse (vulcão, baía, lago, vale, litoral, etc.), vistas de cidades (vedute) de apelo histórico, monumentos arquitetônicos antigos, além de detalhes de ornamentação e de elementos arquitetônicos de construções do passado, ricos em trabalho humano que a sociedade moderna perceberia de maneira cada vez mais nostálgica.

Tudo isso ia contribuindo para estruturar uma linguagem artística relacionada à prática do Grand Tour. Essa linguagem envolvia um temário específico e vocabulário característico, além de um mix de regras de sintaxe visual derivadas de princípios cultivados nas academias de ensino artístico, valores advindos dos hábitos empíricos do registro in loco, modas e afetações da época. É claro que a tradição paisagística da arte européia fornecia uma base sobre a qual as paisagens iam sendo elaboradas durante as viagens, mas, por outro lado, uma arte de paisagem destinada a atender ao gosto dos grand tourists e de seu círculo ia conferindo traços mais específicos à linguagem artística, cheia de particularidades. (SALGUEIRO, 2002)

\section{_ideias de viagens}

Uma vez delineado o papel de disciplina nas viagens de formação, e sua permanência, agora vamos procurar demonstrar como esse aspecto apareceu em viagens ao longo da história, e quais foram esses momentos característicos.

Se a viagem de formação teve seu início nos "grand tours", nas outras manifestações dessa prática, muito permaneceu enquanto hábitos, métodos, estruturas que foram inaugurados com essas "primeiras viagens" de formação.

Mas, considerando a permanência de certas estruturas, podemos falar dos movimentos dessas estruturas das viagens de formação. Como a base desses movimentos está ancorada nas transições históricas, dos comportamentos, 
das culturas, a prática da viagem enquanto estrutura que se identifica, foi se transformando na mesma medida.

Falamos em ideias de viagens para caracterizar momentos históricos peculiares, as ideias de viagens são sempre produto de tradições culturais mais amplas, por exemplo, ainda na ideia do "grand tour", havia um apelo cultural, histórico, social e econômico que proporcionaram a exploração da viagem enquanto prática formativa.

A viagem no formato que se deu nos "grand tours", se ocorresse em outro contexto econômico, os resultados não teriam sido os mesmos, o formato, a duração, os meios de transporte, o foco.

Percebe-se então a existência de aspectos mutáveis dentro da estrutura da viagem de formação, a partir de alterações contextuais mais amplas como a economia, o momento histórico e político. Os aspectos que vão se alterando por essas condições externas são os formatos, as durações por exemplo.

Os formatos se alteraram na medida em que as viagens foram programadas a partir de novas ideias, viagens em equipes, por exemplo, diferente do que acontecia no "grand tour" estrito. Os objetivos de aprendizado em uma viagem foram sendo ampliados, nas viagens marítimas exploratórias, por exemplo, nas investidas em viagens de pesquisa, de teor naturalista, científico.

Quanto à duração das viagens também se nota algumas diferenças, na medida em que algumas começaram a acontecer em um tempo mais estreito, ainda ligado às mudanças nos objetivos, nas novas ideias de viagem.

O passar do tempo trouxe inovações tecnológicas que acarretaram novos formatos de viagem, a partir dos novos meios de transporte, de correspondência, que conferiram às jornadas certa eficiência, alterando também as formas de percorrer o lugar, afetando a percepção que se tem do espaço, da velocidade, chegando até nas linguagens empregadas na representação desse aprendizado.

\section{_a ideia de aventura}

No modelo dos "grand tour" e até das grandes navegações, por exemplo, a ideia de aventura que se tinha da viagem era recorrente; a ideia de aventura é relacionada ao medo do desconhecido, do arriscar-se.

Nesses dois exemplos, "grand tours" e grandes navegações, o arriscarse tem conotações distintas, no entanto; no primeiro, é um lançar-se intelectualmente, como uma busca cultural, de novos repertórios, tradições. No segundo, o objetivo é de caráter exploratório, no sentido econômico. 
$\mathrm{Na}$ etimologia da palavra, "aventura" tem sua origem no latim: "ad venture", que significa "coisas a vir", "coisas que acontecerão", denota certa imprevisibilidade, conceito já tratado aqui como componente estrutural da viagem.

0 momento anterior à aventura situa-se entre o "medo" e a "coragem".

[...] viajar era ainda sinônimo da decisão pela aventura, uma vez que deixar-se estar em um navio por período de 20 a 30 dias era para muitos correr risco demasiado, por mais segurança que esse meio de transporte pudesse prometer. E a aventura nesse caso não dizia respeito apenas à idéia de correr risco, mas, mais do que isso, antes do advento dos grandes e confortáveis transatlânticos, ela se relacionava a uma idéia de renúncia aos confortos do cotidiano, como, por exemplo, o banho de água doce, que nem sempre era disponível. Assim, viajar era, para muitos, um ato de coragem. Implicava o imprevisto, por mais que a viagem tivesse sido planejada. Implicava o risco, por mais seguros que fossem os navios. No início, a imprevisibilidade, componente da aventura, era tida como ameaça, aproximando a viagem do sentimento de "medo". (PIMENTEL, 2001, p.87)

A aventura é sempre uma busca, se ainda pensarmos no verbo do qual deriva o termo "aventura", "advenire", que significa: adevento, "o que vai acontecer", caso inesperado, singular, extraordinário, resultado incerto, arriscado. "alcançar"; uma busca não totalmente controlada, uma busca imprevisível, pode se dizer então. 0 objetivo dessa busca, voltando aos sentimentos de "medo" e "coragem", quando se realiza, o segundo se sobressai ao primeiro.

Na medida em que viaja, o viajante se desenraíza, solta, liberta.

Pode lançar-se pelos caminhos e pela imaginação, atravessar fronteiras e dissolver barreiras, inventar diferenças e imaginar similaridades. A sua imaginação voa longe, defronta-se com o desconhecido, que pode ser exótico, surpreendente, maravilhoso, ou insólito, absurdo, terrificante. (IANNI, 1996, p.19)

Esses adjetivos: "surpreendente", "insólito", “absurdo", "terrificante”, ilustram a face da aventura que dialoga com o "medo", e esse é sempre em relação ao desconhecido, que é de alguma maneira, imprevisível, por isso surpreendente. 0 interessante é notar como o medo se transfigura na decisão de partir em viagem, em cumpri-la, o desconhecido passa a ser incorporado, apreendido, dando lugar à um sentimento agora de liberdade.

Esse sentimento acontece no mesmo momento de dissolução da "ameaça": 
"O desenraizamento ou a libertação, se são sentidos como positivos por muitos dos que têm gosto pelas viagens, são, em outros casos, vistos como ameaça." (PIMENTEL, 2001, p.83)

Dessa forma, outro conceito pode ser relacionado com a ideia de aventura no estudo das viagens, o de "liberdade":

Se as viagens modernas muito se diferenciam das antigas, tanto pelas motivações como pelas condições em que são realizadas, é de se notar que elas guardam ainda a idéia de purgação. Quanto mais se aproxima da idéia de aventura, mais a viagem indica a possibilidade da liberdade. Em certo sentido, os perigos e as fadigas de uma viagem ainda são tidos como um teste do heroísmo do viajante. E se a viagem é intensa, plena de aventuras e novidades, para o viajante ela será um ganho moral e psicológico. (PIMENTEL, 2001, p.83)

O grau de aventura conferido á uma viagem é proporcional ao grau de liberdade que essa possibilita. A aventura da viagem fala sobre a intensidade dos desafios do percurso, assim como nas palavras de Pimentel, isso é revertido em ganho moral e psicológico para o viajante.

\section{_viagem e ciência}

Novamente como foi feito com o termo "aventura", "ciência" vem do latim "scientia", que significa conhecimento, de "scire", que significa saber, distinguir e separar coisas.

No momento selecionado para observar o florescimento de algumas viagens de formação, o do Renascimento, a ciência deve ser lida como um tema cultural.

A ciência foi contextualizada então enquanto objetivo cultural do Renascimento.

Foi nesse contexto em que floresceram as viagens naturalistas, essas devem ser lidas a partir de uma tradição cultural própria do movimento artístico intelectual que foi o Renascimento.

As tradições culturais que foram representativas do Renascimento, dos séculos XIV e XVI surgiram a partir da ruptura com as tradições medievais, incentivado por um fenômeno de urbanização crescente, da expansão comercial e marítima. Foi sendo firmada uma nova ordem econômica, social e política, com efeitos na cultura de forma ampla. 


\section{mecenato}

O Renascimento enquanto movimento intelectual e cultural amplo teve essa dimensão de resgate dos valores e tradições de antiguidade clássica, representada pela Grécia antiga, focando seu desenvolvimento na expressão da racionalidade, e de um ideal ao mesmo tempo humanista e naturalista. Uso da razão individual e busca pelo conhecimento empírico, analítico, diferentemente da escolástica medieval.

O Renascimento difundiu como ideal cultural o homem investigador, justificando seu embasamento na natureza racional do homem. Foi nesse contexto de valorização da liberdade e autonomia humana, que ocorreu o desenvolvimento da cultura e do olhar que se constituiria como "moderno". 0 período do Renascimento inaugurou um marco dessa visão de mundo, que viria a influenciar muitas esferas da vida individual e social do homem moderno, depois ainda se desenvolvendo e aludido em um movimento posterior, o Iluminismo, no século XVIII.

Em termos de produção cultural, no que toca ao tema das viagens de formação, a viagem enquanto campo disciplinar proporcionava um método de conhecimento próprio das tradições culturais do movimento renascentista.

As viagens que aconteceram no âmbito da modernidade encaravam a experiência de aprendizado por ela proporcionada como um jogo de análise, discernimento e síntese acerca dos objetos e espaços visitados, a partir de uma matriz racional, objetiva, própria do Renascimento:

Rejeitando as linguagens do passado, os mentores da modernidade procuram novos fundamentos para a arte da pósrevolução industrial, num sentido que vai para além do seu mais evidente mimetismo. Embora o regresso às origens do mundo greco-romano não deixe de representar certo paralelismo com o mesmo movimento de renovação do período renascentista, a síntese operada através dessa experiência de viagem vai resolver a esterilidade de um processo criativo que se inicia com o mote da máquina e da produção em série. Será o tema e consequências das viagens de Lewerentz, Asplund, Le Corbusier, Alvar Aalto, Mies Van der Rohe, Bruno Taut, Louis Kahn etc. (GONÇALVES, 2012, p.199) 


\section{_viajantes típicos, viajantes tipo}

A partir de alguns viajantes é possível caracterizar momentos da história das viagens de formação como ela vem sendo contada nesse capítulo.

Para além dos tipos de viagem que podemos delinear com características, contextos mais ou menos comuns, existiram viajantes que mais do que se inserirem nesses tipos de viagem, borram as fronteiras entre um e outro, carregando os registros e suas práticas de sua personalidade, enxergando ou mesmo inserindo dentro de uma estrutura rígida como a clássica do "grand tour" uma oportunidade de ultrapassá-la, inventando um novo jeito de viajar, que depois vai servir como modelo pra outros viajantes em formação.

\section{_Le Corbusier, arquiteto moderno em trânsito}

Le Corbusier (1887-1965) foi um dos arquitetos modernos cujas viagens mais claramente participaram da construção de uma teoria e prática de arquitetura fortemente personalizada. Compreender as suas viagens é, assim, também um meio de compreender a sua obra. (GONÇALVES, 2012, p.200).

Dos viajantes típicos, existem expoentes de cada área e de cada modelo de viagem, entendendo-se aqui, modelos de viagem, como todos os padrões de práticas, itinerários, que compõem um "grand tour". Le Corbusier é um exemplo, daqueles que transpôs a definição em um ou outro modelo. Situase inicialmente, no lançamento da viagem, em algo parecido com a ideia de "grand tour", com um itinerário absolutamente determinado, mas imprime, ao mesmo tempo, sua forma de ler as paisagens, os edifícios, as cidades, nesse modelo de viagem do qual parte, abrindo ai caminhos para outros arquitetos, que posteriormente, cumprirão trajetórias parecidas.

No itinerário de viagem de Le Corbusier, é possível perceber, tanto uma transição de destinos, como a forma de ele encarar a experiência de viagem, a partir de seus registros, como cartas, desenhos, que vai do clássico ao medieval, do oriente, ao popular, da mesma forma que acontece como o modo de investigação, de desenhos de detalhes ornamentos, para uma apreensão do entorno, da paisagem da cidade.

0 trânsito que se observa com o jovem Jeanneret em viagem tem correspondência com o que acontece no interior do movimento moderno.

O movimento moderno na arquitetura tem, em seu início, busca negar a arquitetura do passado e sua de ornamentação e estilo. Postura que leva a 
atuação e defesa, por parte de Le Corbusier, de uma arquitetura internacional. Postura expressa claramente em vários de seus textos, como aqueles que compõe o livro "Por uma arquitetura" ${ }^{6}$, livro-manifesto, no qual são discutidos conceitos desde funcionalidade na arquitetura até o que seria esse "novo homem" a partir de uma nova estética.

Nas trajetórias das viagens, de forma quase alegórica, é visível uma transição, nas viagens para a Itália e para o Orinte, na forma de olhar para a arquitetura do passado. Quando, na primeira viagem ${ }^{7}$, Le Corbusier olha para um edifício da Roma Antiga, sua atenção se concentra não nos ornamentos, mas na sua estrutura formal, funcional, tipológica, do qual ele extrai a organização, de forma analítica.

Essa organização que Le Corbusier identifica nas obras que observa está contida, em potencial, em suas anotações de viagem, nos croquis, e é com essa potencialidade que ele dialoga, e de certa forma, responde, arquitetonicamente em novos arranjos ao longo de sua trajetória profissional.

Nesses termos, é possível olhar de forma distinta para os dois momentos dessa relação interpretativa dos edifícios, em sua primeira e segunda ${ }^{8}$ viagem.

\section{_primeira viagem}

Em 1907, com então apenas 20 anos, a primeira viagem do jovem Jeanneret teve como destino as cidades italianas, por um período de aproximadamente três meses ${ }^{9}$. Nessa primeira viagem, Le Corbusier faz o redesenho da clássica viagem à Itália, mas imprime um modo próprio na interpretação do passado que ele encontra em viagem.

Le Corbusier, por sua vez, retrata bem a experiência de um arquiteto viajante. Podemos compreender a formação de Le Corbusier, e em seu sentido mais amplo, sua trajetória profissional através de suas viagens.

Entendendo, no contexto desse trabalho, que a viagem tem o papel de

6 Este foi o primeiro trabalho teórico sobre arquitetura escrito por Le Corbusier em 1923.A obra é um conjunto de ensaios publicados na revista Esprit Nouveau, fundada em 1919.

7 As primeiras viagens são correspondentes ao ano de 1910, viagens endereçadas às cidades italianas, à Viena, Alemanha, e aos Bálcãs.

8 A segunda viagem de Le Corbusier corresponde aos anos de 1910 e 1911, quando parte para o Oriente.

9 O jovem Jeanneret viaja de setembro à novembro de 1907, período em que percorre as cidades de Milão, Florença, Siena, Bolonha, Pádua e Veneza. 
disciplina dentro da formação do arquiteto, era já uma ideia existente que um arquiteto se formava através dos edifícios e cidades que observava, desenhava e aprendia com ele.

Uma primeira apreensão sobre os registros deixados dessa primeira viagem, sendo a maioria dos documentos existentes, desenhos e fotografias, o estudo desse conjunto leva a interpretação de um mapeamento dos clássicos, produzindo um reconhecimento cultural.

O itinerário dessa primeira viagem foi reconstituído a partir da sistematização das correspondências trocadas por Le Corbusier e seu parceiro de viagem, o escultor Leon Perrin, por Giuliano Gresleri ${ }^{10}$. A própria reconstituição da história da viagem é feita pelo acesso de seus registros, e da interpretação deles, das cartas, juntamente com os desenhos.

O planejamento cuidadoso do itinerário se deu juntamente com seu mestre e incentivador na escola de Artes de La-Chaux-de-Fonds. A definição do roteiro foi feita baseada na viagem, percorrida, três anos antes pelo seu mestre, pela Itália, com atenção à região da Toscana. Há muitas similaridades entre a viagem de L'Eplattenier e o itinerário percorrido por Jeanneret.

O Itinerário em si se realizou na seguinte ordem: Partindo De La Chaux de Fonds em $1^{\circ}$ de setembro para Bern, Luzem, Gottardo, Lugano, quando então chega a Milão entre os dia 4 e 5 de setembro. Depois de Milão, vai a Paiva, Genova, Carrara, Pisa e Florença, cidade em que passa mais tempo em relação às outras localidades visitadas, chegando a permanecer na cidade, cerca de um mês. Depois do tempo em que permaneceu em Florença, parte em direção a Veneza passando por: Faenza, Ravena, Ferrara, Bolonha, Mantova, Peschiera, Gargnanao, Riva, Desenzano, Verona, Padova e Veneza, cidade esta que também tem uma permanência mais longa, de 14 dias.

Dessa viagem de 1907, Le Corbusier colecionou, entre os "carnets", e cartas, cerca de 70 desenhos e 25 correspondências (LANCHA, 2006), nas quais ele se comunicava com familiares, e conta, de maneira subjetiva, as experiências, sensações que tinha longe de casa, contando desde as surpresas até as reclamações.

De Florença, em 14 de setembro de 1907, Jeanneret endereça uma carta aos seus pais:

10 Guiliano Gresleri é um arquiteto italiano, professor de história e arquitetura da Universidade de Bolonha, autor de livros como "Carnets du Voyage d'Orient" (Electa, Milão, 1987), Le Corbusier, a “linguagem das pedras” ( Marsilio, Veneza, 1988). 


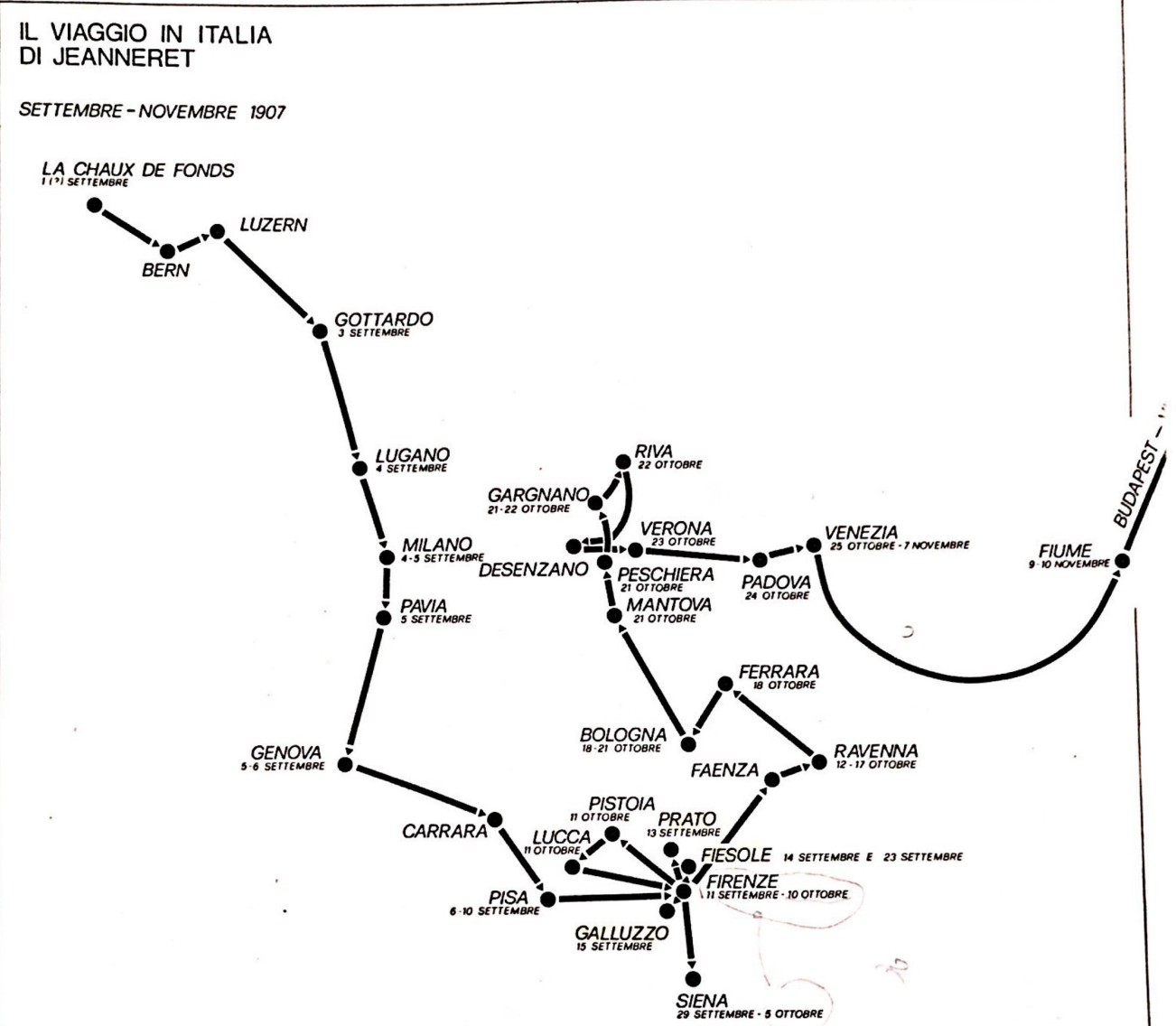

Figura 1: Mapa da viagem à Itália. FONTE: GRESLERI, 1987.

Estive ontem na cartuxa de Ema, espero não ter já lhes contado e ali encontrei a solução para a casa operária tipo único. A única coisa que será difícil encontrar é esta paisagem. Que sortudos esses mônacos! Sábado pela manhã, a Fiesole, que sortudos esses monges!, a minha admiração foi a mesma na cartuxa de Pavia e pude convencer-me que, todavia renunciando ao mundo, eles sabem ao menos procurar para si uma vida deliciosa, e sou persuadido a crer que, ao fim das contas, eles é que são felizes e sobretudo são ainda eles que tem em vista o Paraiso. (LE CORBUSIER, 1907)

Do fragmento dessa carta, Jeanneret descreve as sensações e observações que teve na visita da cartuxa de Ema, o comentário que ele escreve diz sobre o envolvimento com a atmosfera do local, com a observação da vida de quem habita aqueles edifícios, na busca de entender, tipologicamente, na arquitetura, 
o que provoca aquele ambiente em que ele se insere e reconhece como agradável.

"Trabalho muito, mas não consigo fazer o mínimo croqui, que se possa chamar assim. A minha mão é rígida e tensa, sempre cansada, e me agarro ao lápis como a uma âncora de salvação. Paciência, borro tantos papeis, e levarei recordações. Perrin, ele faz desenhos muito bonitos, bem feitos e com arte. Ele se especializa em escultura e um pouco em afrescos, enquanto eu sou obrigado a interessar me de tudo, uma vez que a arquitetura abraça absolutamente tudo, colocando em tudo a sua marca." (LE COSBUSIER, 1907)

Nessa outra carta $^{11}$, carregada de muitos significados, Jeanneret começa num misto entre lamentação e justificativa da própria lamentação, por entender a abrangência da arquitetura, quando compara seus croquis, errantes, insistentes, com os desenhos de Perrin, como ele diz, "bem feitos e com arte". Há, no seu discurso, uma explicação do que se trata o fazer da pesquisa de arquitetura, do olhar amplo que se faz necessário, e da determinação de desenhar e compreender, ao mesmo tempo, elementos desse todo. 0 lugar da arquitetura seria então, na compressão de Jeanneret, o da compreensão do todo, que é o que a disciplina arquitetura abarca, "absolutamente tudo".

É esse entendimento que guia a viagem italiana de Le Corbusier, ao visitar cada cidade, captar esse todo e observar, anotar os elementos.

Nessa viagem, Le Corbusier, a modo de um viajante de "grand tour", faz uso das experiências percorridas por outros viajantes, desenhistas, como Ruskin $^{12}$, seus mestres, e até viagens de estudos anteriores de seu colega Leon Perrin. Como vimos anteriormente, essa prática de consultar guias, registros de viagem de outros viajantes, desenhistas era uma prática comum dos viajantes, na etapa de preparação da viagem, muitos itinerários foram definidos com apoio nessas influências.

Le Corbusier retira da experiência de viagem de John Ruskin, o modo de desenhar, como um recurso em que era possível fazer associações, para pensar o espaço. Ruskin, na posição de professor, instrutor de seus alunos de desenho preferia uma investigação empírica pautada na individualidade do olhar de cada aluno ao método regular.

Mas a influência de Ruskin não deve ser atribuída só ao itinerário

11 Carta de Jeanneret endereçada aos pais em 8 de outubro de 1907, durante sua estadia em Florença.

12 John Ruskin foi um escritor, ensaísta, viajante, desenhista e crítico de arte britânico. 
e à seleção das obras. Jeanneret observou também seus desenhos e a aproximação entre eles é muito evidente. A escolha do enquadramento do edifício na página, o enfoque figurativo dado à sua representação servem de estímulo inicial também à produção de Jeanneret. Ruskin se preocupa com as fachadas, com a paisagem, elemento prioritário de sua investigação, reveladas através de detalhes onde o contraste mais intenso entre figura e fundo é sempre explorado. (LANCHA, 2006, p.56)

Ruskin apoia sua produção no pensamento pitoresco, no qual as partes, em unidade são associadas para dar sentido ao todo.

[...] a única coisa que pedia a esse olhar é que fosse composto por associações de assuntos justapostos, por memórias e simultaneidade de tempos, esperando com isso o aflorar da lógica natural para a consciência do observador. (AMARAL, 2013)

Dessa forma, seu ensino foi baseado em uma teoria da percepção, como elemento estruturador, dando visibilidade a todos os temas que foram associados no âmbito do pensamento.

A obra, o passado a ser investigado, passa a se configurar como meio de trabalho, e o olhar que busca associações, uma postura profissional das viagens de Le Corbusier, enquanto formação do arquiteto.

Transformando esse seu confronto direto com a obra em prerrogativa de trabalho que supera o momento de formação para permanecer como estratégia ao longo de sua atuação profissional. (LANCHA, 2006, p.54)

0 arquiteto viajante busca entender a estrutura que organiza um edifício, para além de camadas mais superficiais, como o estilo, a ornamentação, pelo desenho investigativo, associativo que registrou nas viagens.

O principal resultado dessa recolha documental será a definição de um método de trabalho paradigmático que se centrará num contínuo reuso e regeneração das formas. A história, e nesse sentido o conhecimento adquirido no contato com as obras do passado, transformam-se numa ferramenta que permite, ao indagar como e porque se projetou, saber projetar. (GONÇALVES, 2012, p.203)

Talvez por que o desenho que representa a arquitetura deva ter características diversas do desenho que observa a escultura ou mesmo a pintura e nesse momento Jeanneret já parece já ter intuído essa diferença. Seus desenhos de espaços internos são muito mais analíticos e desenvolvidos com traços rápidos, 
enquanto que toda as cores e a riqueza de ornamentos das fachadas dos edifícios parece induzir Jeanneret, a um desenho de grande elaboração e fadiga. (LANCHA, 2006, p.64)

\section{_segunda viagem}

A segunda viagem, com duração de sete meses, ainda foi dotada de uma intenção inicial parecida com a primeira, no modelo de uma bolsa concedida pela Escola de Artes de La Chaux-de-Fonds, só que destinada ao estudo dos novos movimentos das artes aplicadas, começa em abril de 1910, três anos depois da viagem às cidades italianas.

A novidade que essa viagem trás é que, mesmo com um roteiro prédefinido, o tempo de permanência nos locais visitados, e os contatos que o

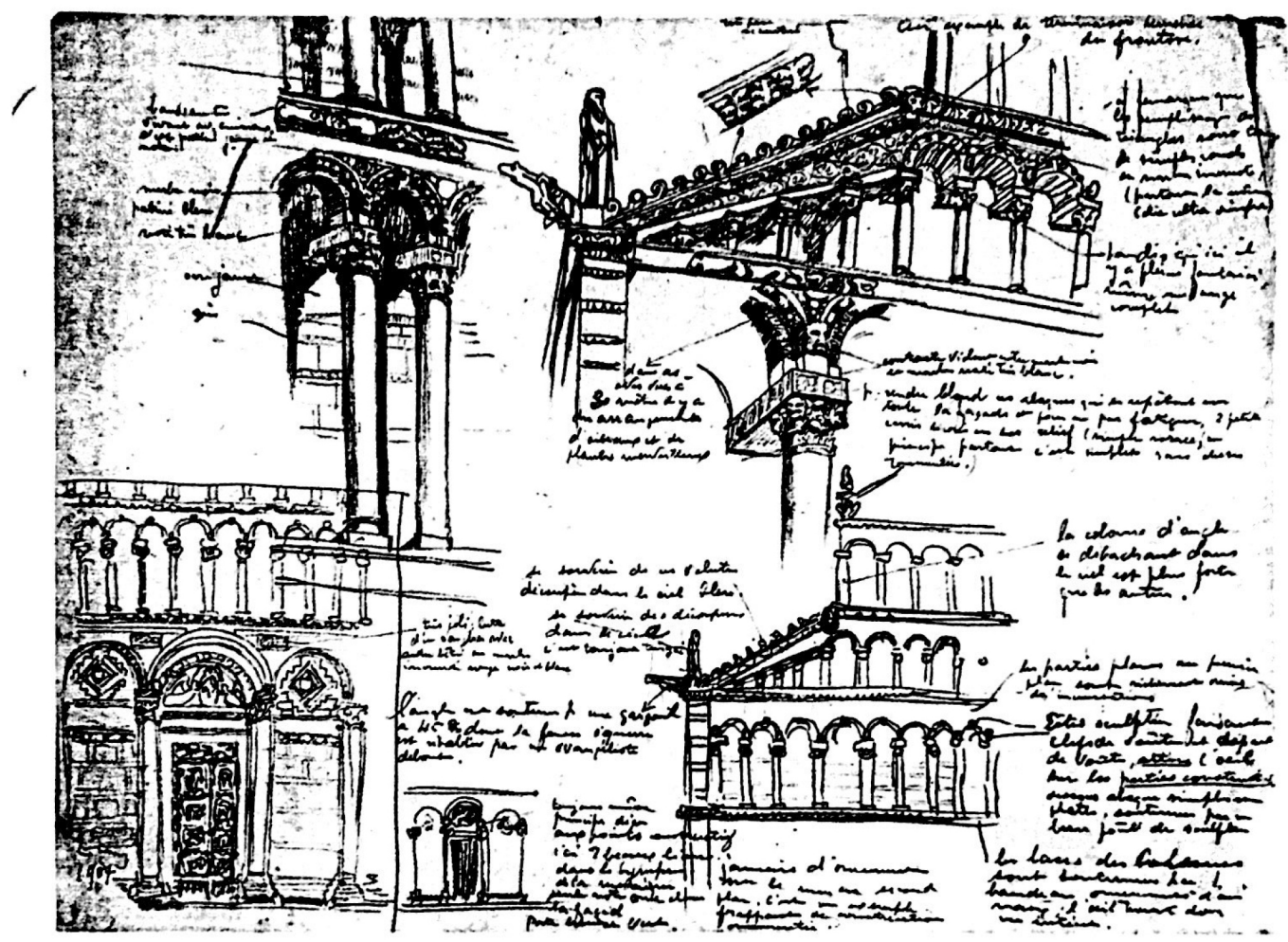

Figura 2: LE CORBUSIER, 1907. Pisa, duomo. FONTE: Catálogo da mostra org. por Giuliano Gresleri, Venezia: Marsilio, 1987. 
viajante faz com outras culturas e personagens trazem para esse exemplo, o componente da imprevisibilidade da viagem, da transformação do itinerário e do olhar, dentro da mesma viagem.

Se o itinerário original se concentrava em Berlim, na Alemanha, o viajante busca, dentro dessa estrutura inicial próxima a um "Grand Tour", territórios menos industrializados, menos ocidentais. Nessa altura, Le Corbusier viu na arquitetura moderna alemã o que chamou de banalidade, e começou a buscar e se interessar pela temática do exótico, e acreditava que esses questionamentos se intensificariam se ele buscasse esses territórios no Oriente.

Quanto à escolha dos itinerários nessa segunda viagem de Le Corbusier estudada, ele deixa de lado obras icônicas, fazendo outro tipo de seleção, se demorando mais em algumas cidades, praças e edifícios.

Nesses lugares visitados, se intensificou, em relação à primeira viagem, o reconhecimento e exploração das tipologias arquitetônicas através dos desenhos. Esse reconhecimento aparece em forma de anotações em seus desenhos de plantas e esquemas.

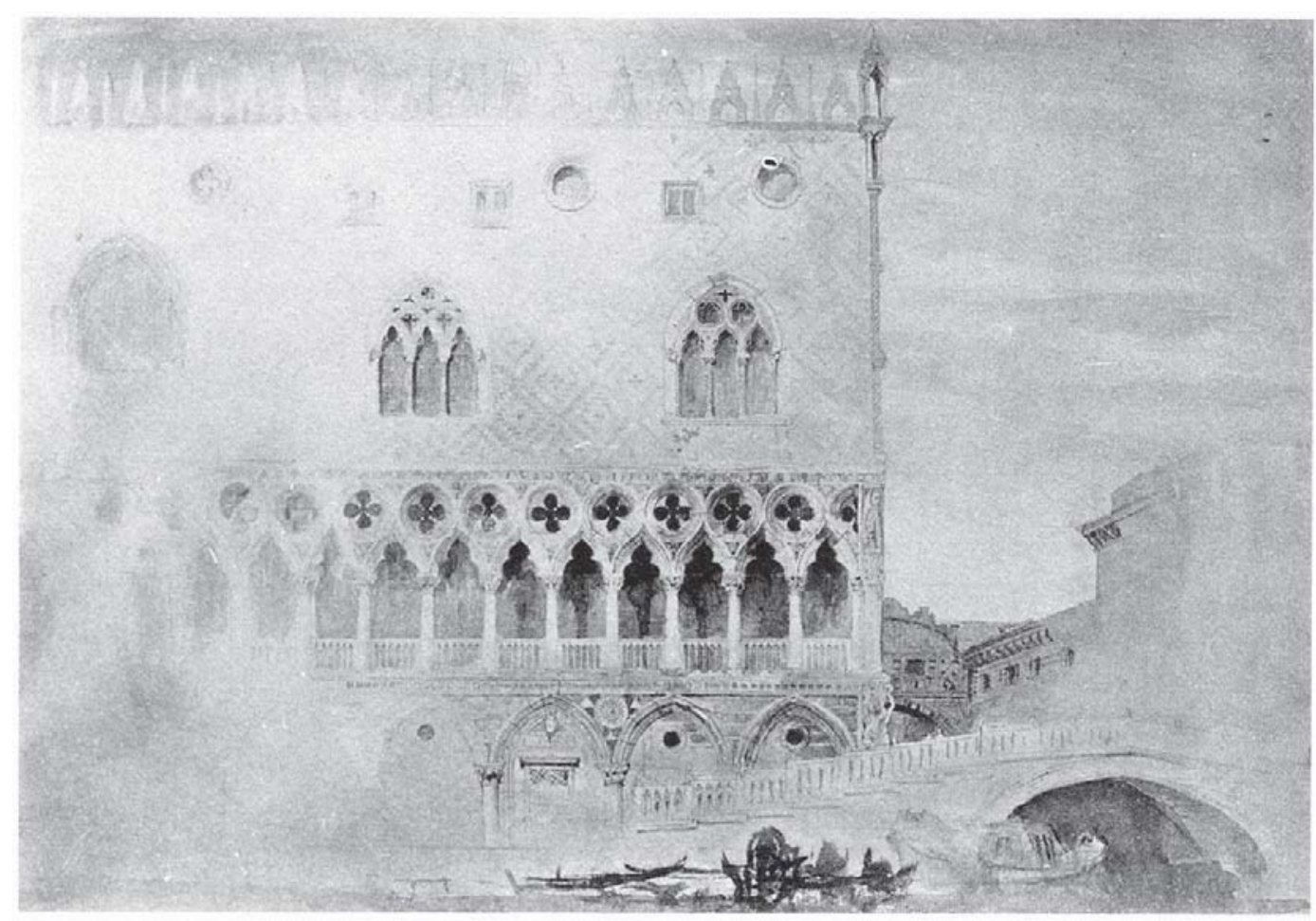

Figura 3: Desenho Palácio Ducal.

1845. FONTE: Ruskin, John. Viaggi in

Italia. Org. por Brilli, Attilio. Passigli

Editori, Florença, 1985. 


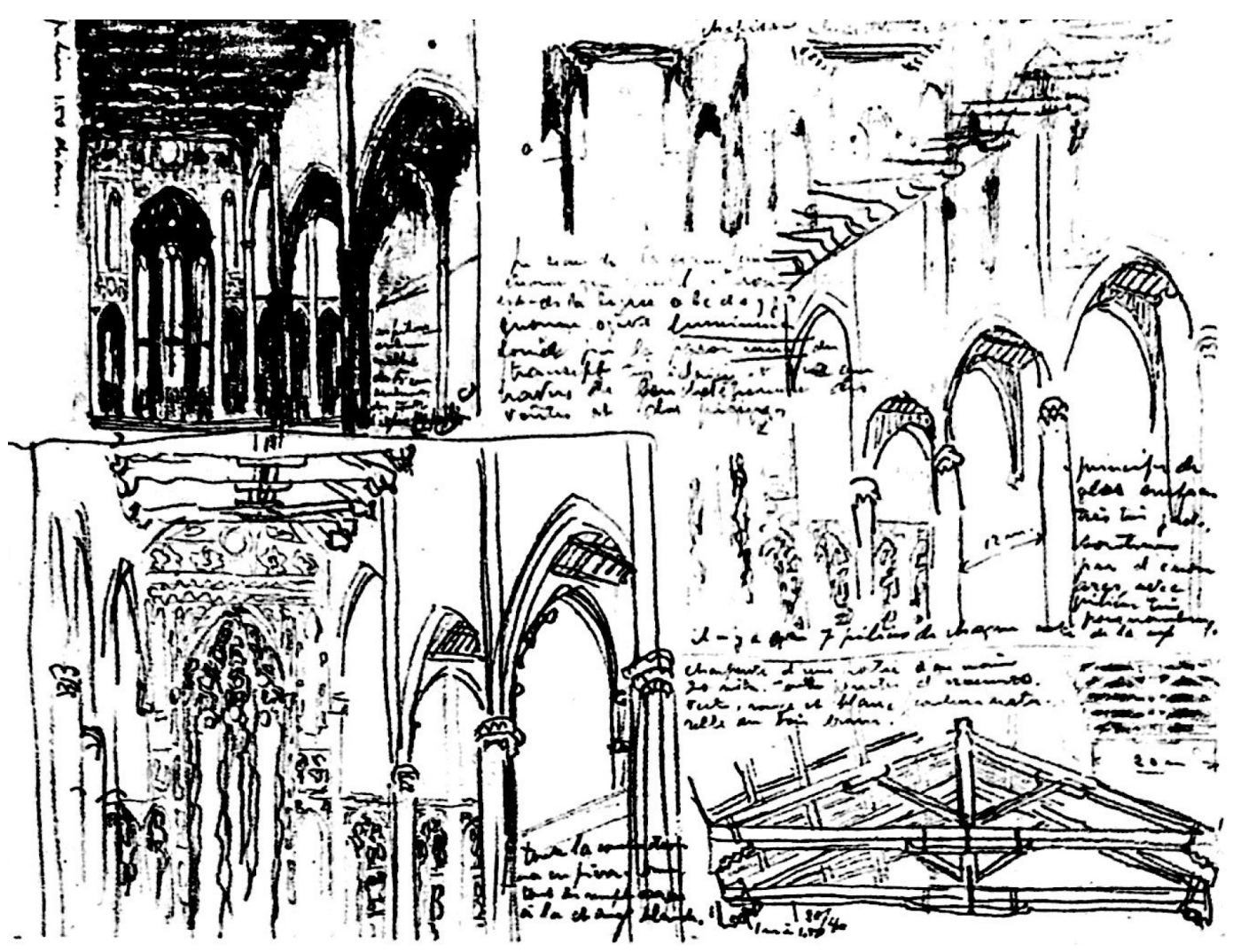

Figura 4: LE CORBUSIER, 1907.Florença, Santa Croce. Estudo interno. FONTE: Catálogo da mostra org. por Giuliano Gresleri, Venezia: Marsilio, 1987

Nesse segundo momento, já não é mais o edifício isolado nem seus detalhes e ornamentos que chama a atenção de seu olhar; ele parece estar atento ao conjunto arquitetônico como um todo e com a relação entre as construções, igualmente interessado em apreender o espaço em sua totalidade. Essa preocupação é evidente na própria fatura do desenho, nitidamente composto de poucos traços sumários, executado de maneira mais rápida e aproximando-se de um esboço ou de um registro de uma idéia a qual irá recorrer posteriormente. (SODRÉ, 2010, p.43)

Os desenhos dessa fase são densos em informações, e foram produzidos com uma metodologia investigativa, de busca e descoberta. Em termos de referências de outros viajantes, pode ser associado à experiência da viagem de Goethe, de transformação e de busca, de uma curiosidade científica e cultural, como observou GONÇALVES (2012, p.200).

Nessa fase, a postura de Le Corbusier viajante era próxima ao peregrino, como tipo de viajante. 0 peregrino tem uma postura peculiar, conversa mais afinado com a possibilidade do imprevisível em viagem, é mais aberto à novos itinerários, é mais permeável. 


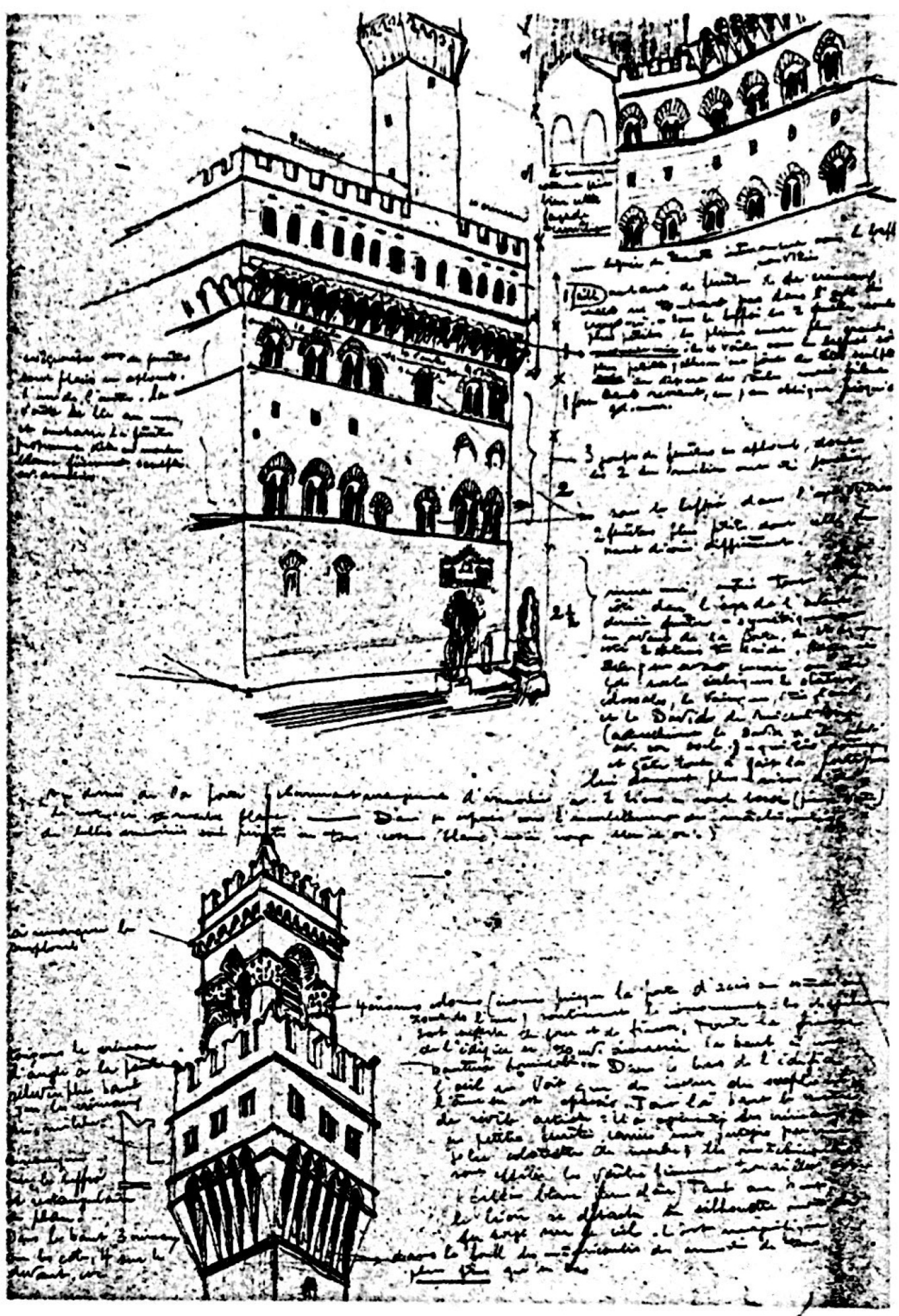

Figura 05: LE CORBUSIER,

1907. Florença, Palazzo Vecchio. FONTE:Catálogo da mostra org. por Giuliano Gresleri, Venezia: Marsilio, 


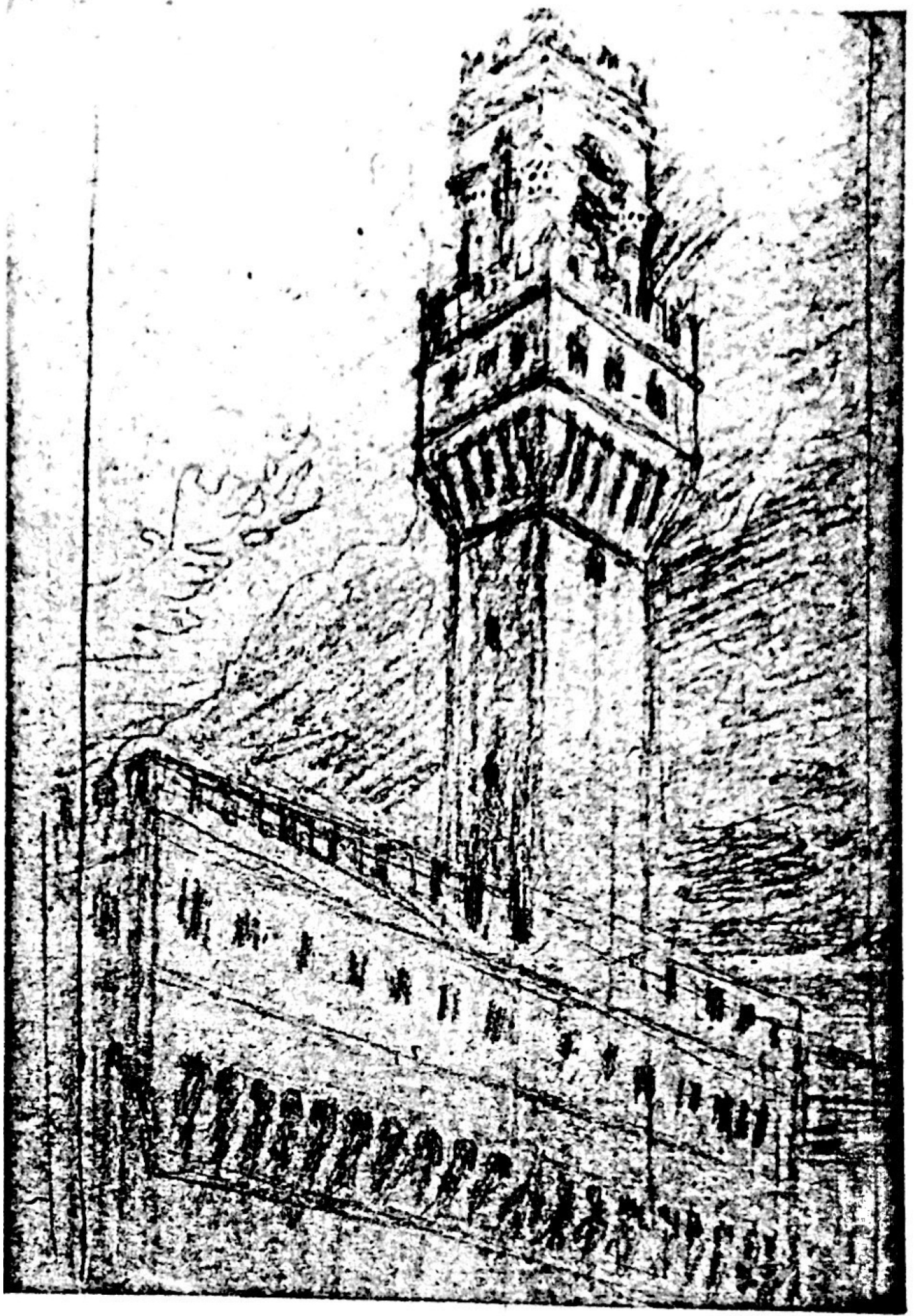

Figura 6: LE CORBUSIER, 1907. Palazzo Vechio. FONTE: Catálogo da mostra org. por Giuliano Gresleri, Venezia: Marsilio, 1987 


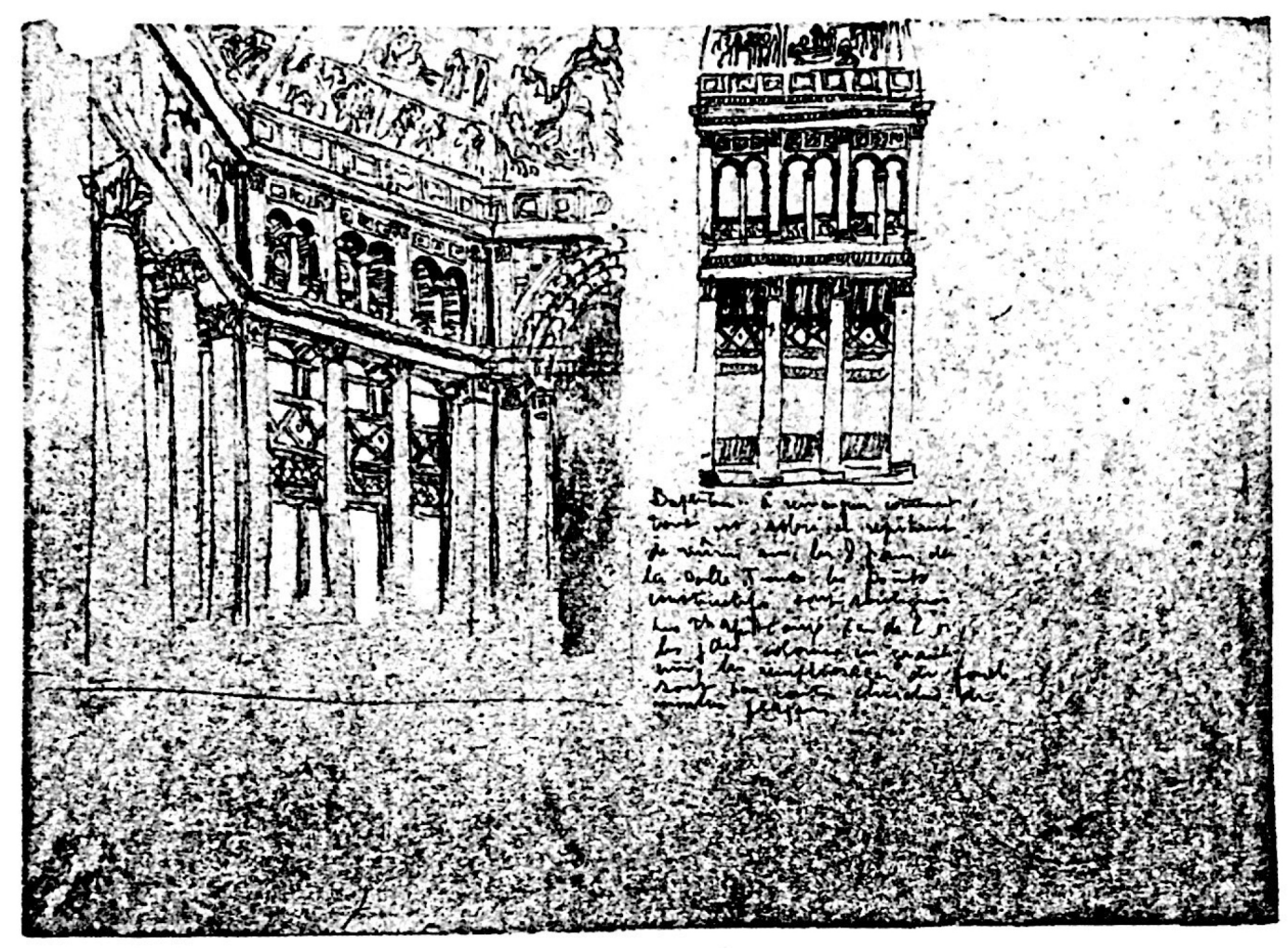

Figura 7: LE CORBUSIER, 1907.Florença, Battistero. FONTE: Catálogo da mostra org. por

Giuliano Gresleri, Venezia: Marsilio, 1987

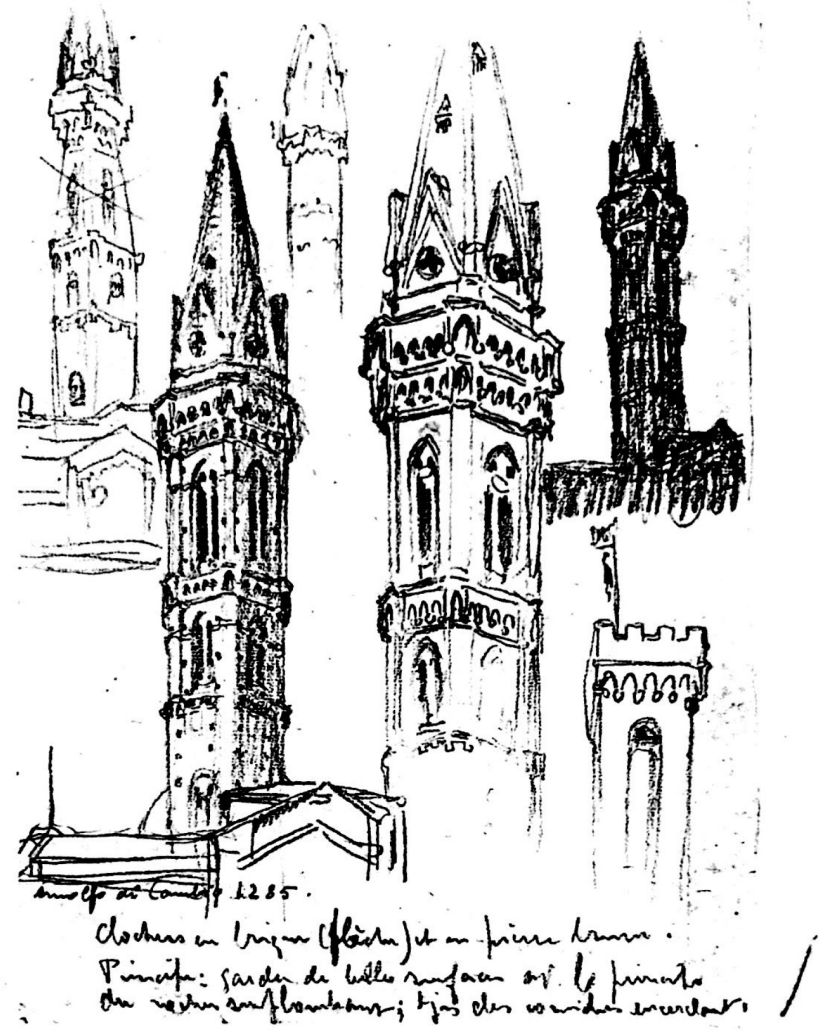

Figura 8: LE CORBUSIER, 1907. Florença, estudo do campanário de Badia e da torre de Bargello. FONTE: Catálogo da mostra org. por Giuliano Gresleri, Venezia: Marsilio, 1987 

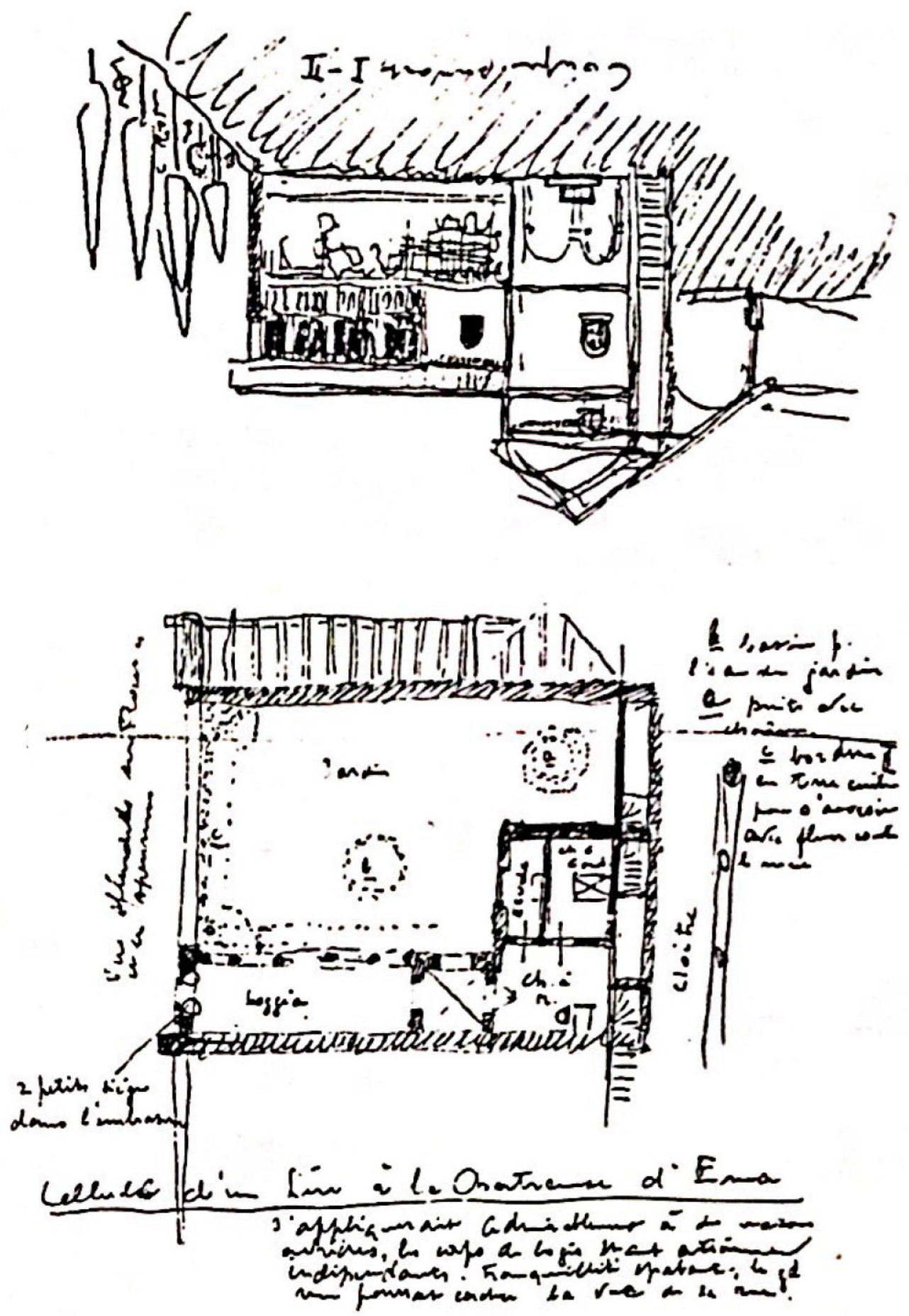

Figura 9: LE CORBUSIER. 1907. Florença, estudo da Cartuxa de Ema, 15 de setembro de 1907. FONTE: GRESLERI, 1987. 


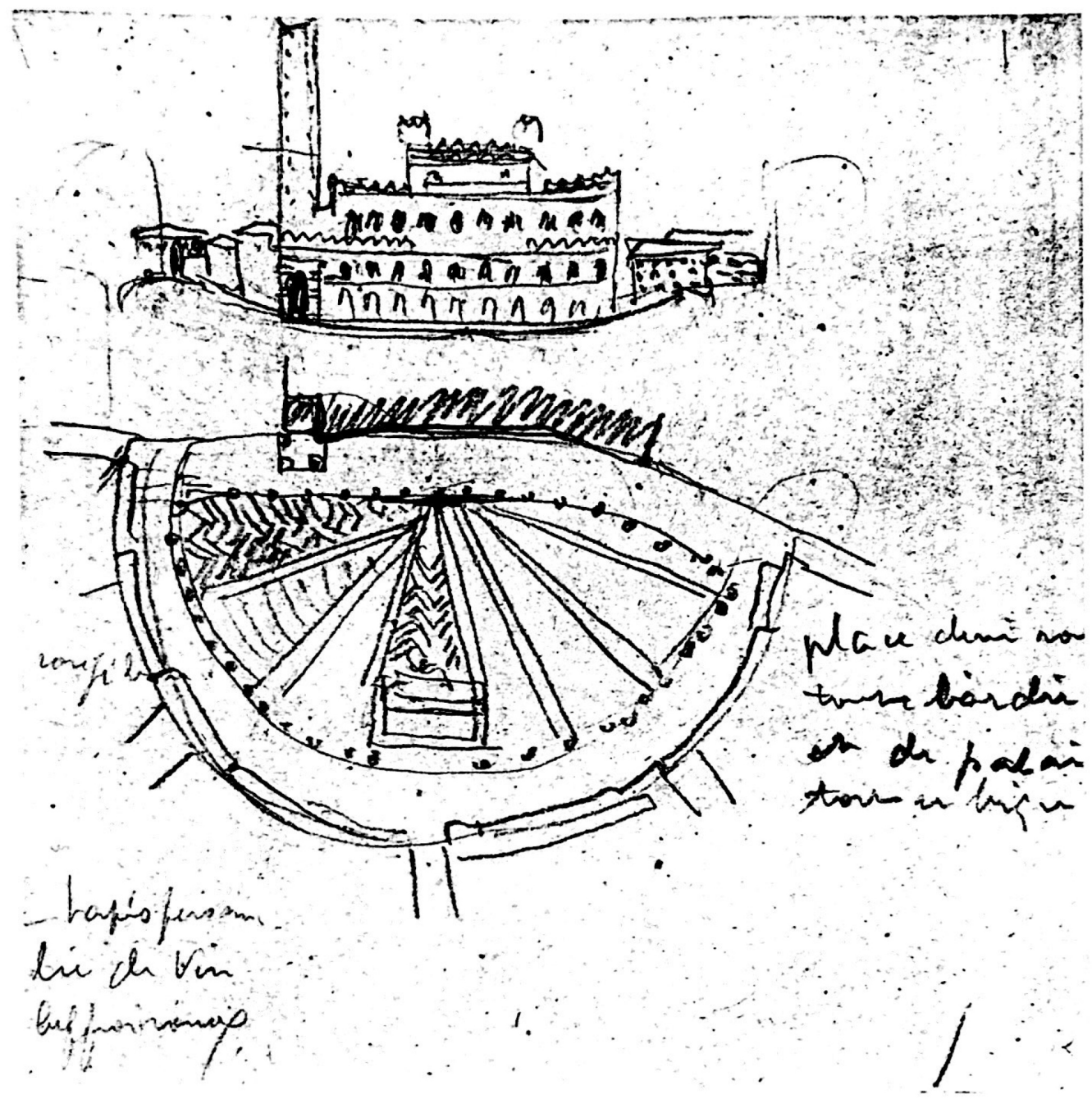

Figura 10: LE CORBUSIER, 1907.

Siena, estudo da Piazza del Campo. 29

de setembro e 5 de outubro de 1907.

FONTE: GRESLERI, 1987. 


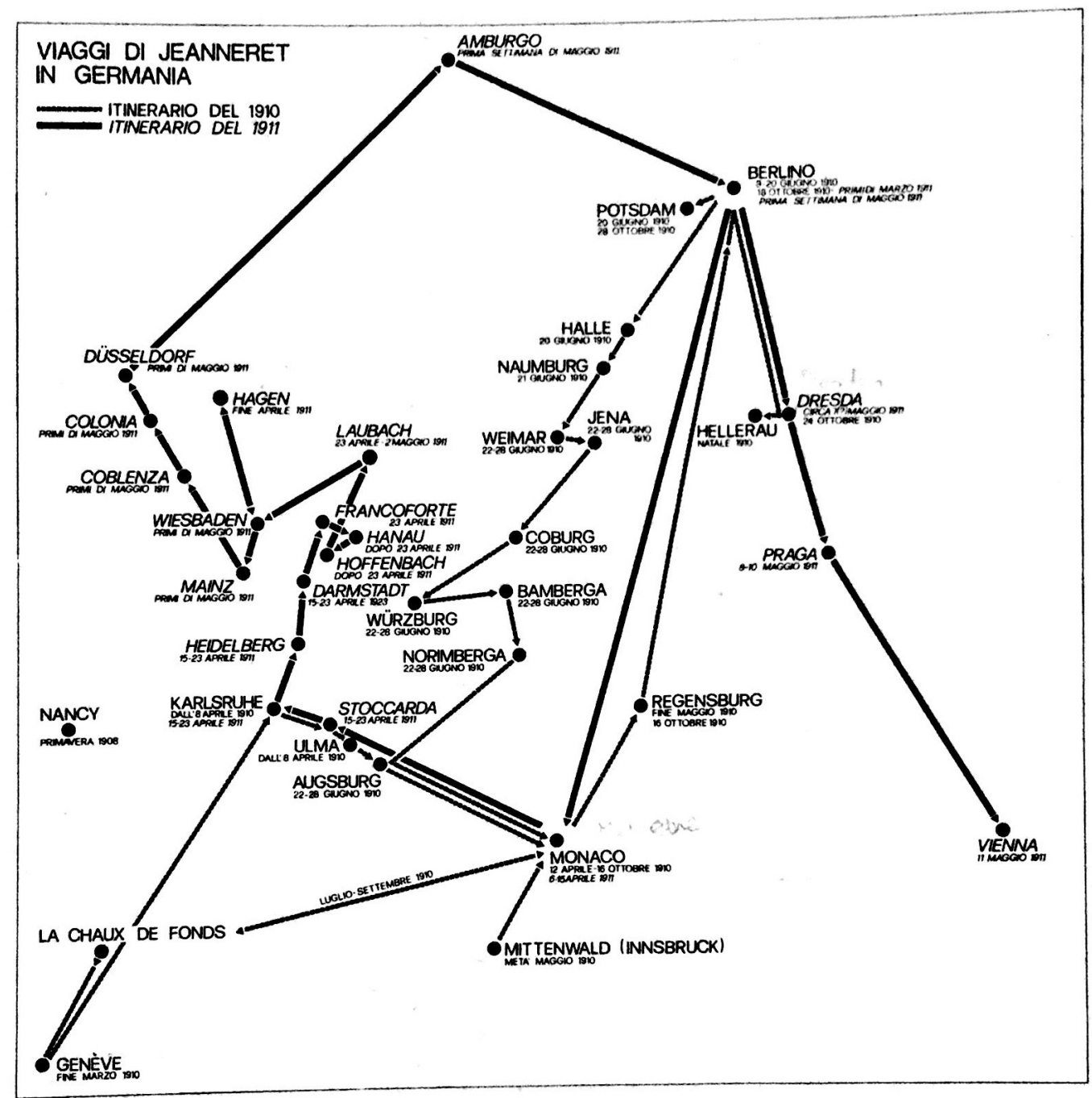

Figura 11: Mapa da viagem ao oriente. FONTE: GRESLERI, 1987

Podemos entender os desenhos contidos nos "carnets" como um desvio disciplinar em relação à proposta inicial da viagem, à expectativa do "grand tour", os desenhos são mais densos, captam do viajante uma urgência em representar o impacto que esses novos territórios tiveram sobre o viajante.

O componente do "impacto" é uma característica bastante forte dos edifícios e paisagens dessa segunda viagem:

Se o impacto das mesquitas e da cidade de Istambul é enorme e ocupa uma parte central da narrativa da viagem, será, contudo, nas ruínas de Atenas, Pompeia e Roma que descobrirá a verdadeira natureza do problema da arquitetura. Lugares de formas e espaços em que a unidade e uniformidade do material, 
bem como a confirmação de uma geometria simples que regula o fato arquitetônico. (GONÇALVES, 2012, p.204)

O impacto, contudo, não se dá pela quantidade e complexidade dos ornamentos, mas é maior, inclusive, quando Le Corbusier compreende a força da arquitetura, em termos de organização, quando a encontra na uniformidade do material, quando a informação essencial é evidente.

Essas constatações que Corbusier começa a chegar nas viagens terá um denso desenvolvimento ao longo de sua trajetória profissional, de muita importância, e são nas viagens que esse processo se inicia.

[...] o reflexo de uma mais apurada proposta plástica que congrega uma síntese operativa e abstrata para os tempos modernos vai surgir apenas no decorrer dos anos 20; primeiro no âmbito do Purismo e depois na arquitetura. Nem por isso, em distintos momentos e obras que atravessam a sua vida profissional, se deixa de encontrar referências mais ou menos sutis aos ambientes, símbolos ou tectônicas que terá descoberto naquelas primeiras viagens, numa reação em cadeia que explica o nexo entre os desafios que se coloca e as propostas de solução que encontra. (GONÇALVES, 2012, p.204)

Com o desenrolar dessa segunda viagem, observa-se, no desenho, a predominância de um traço mais livre, mais expressivo, que se concentra no essencial, afastando-se de um desenho de observação propriamente dito. Nos registros, é possível observar uma transformação, onde o viajante acaba:

[...] afastando-se cada vez mais dos guias de viagens, adquirindo um matiz próprio, de relativa ambição literária, aproximando-se do relato pessoal, de testemunho cheio de opiniões e inquietações. A mesma variação pode ser encontrada nos registros gráficos, que aos poucos vão deixando de ser meros desenhos de observação para se tornarem desenhos investigativos, próximos a esboço, revelando uma capacidade de apreender aquilo que vê com poucos e precisos traços, em apanhar as anotações essenciais. (SODRÉ, 2010, p.51)

O formato do registro nos mostra como essa transformação foi processada, evidente nos cadernos. Essa nova relação com o mundo, iniciada já na primeira viagem de Le Corbusier à Itália, vai permanecer e se intensificar, desde os registros da viagem ao Oriente.

Voltando ao objeto principal de pesquisa de Le Corbusier durante suas 


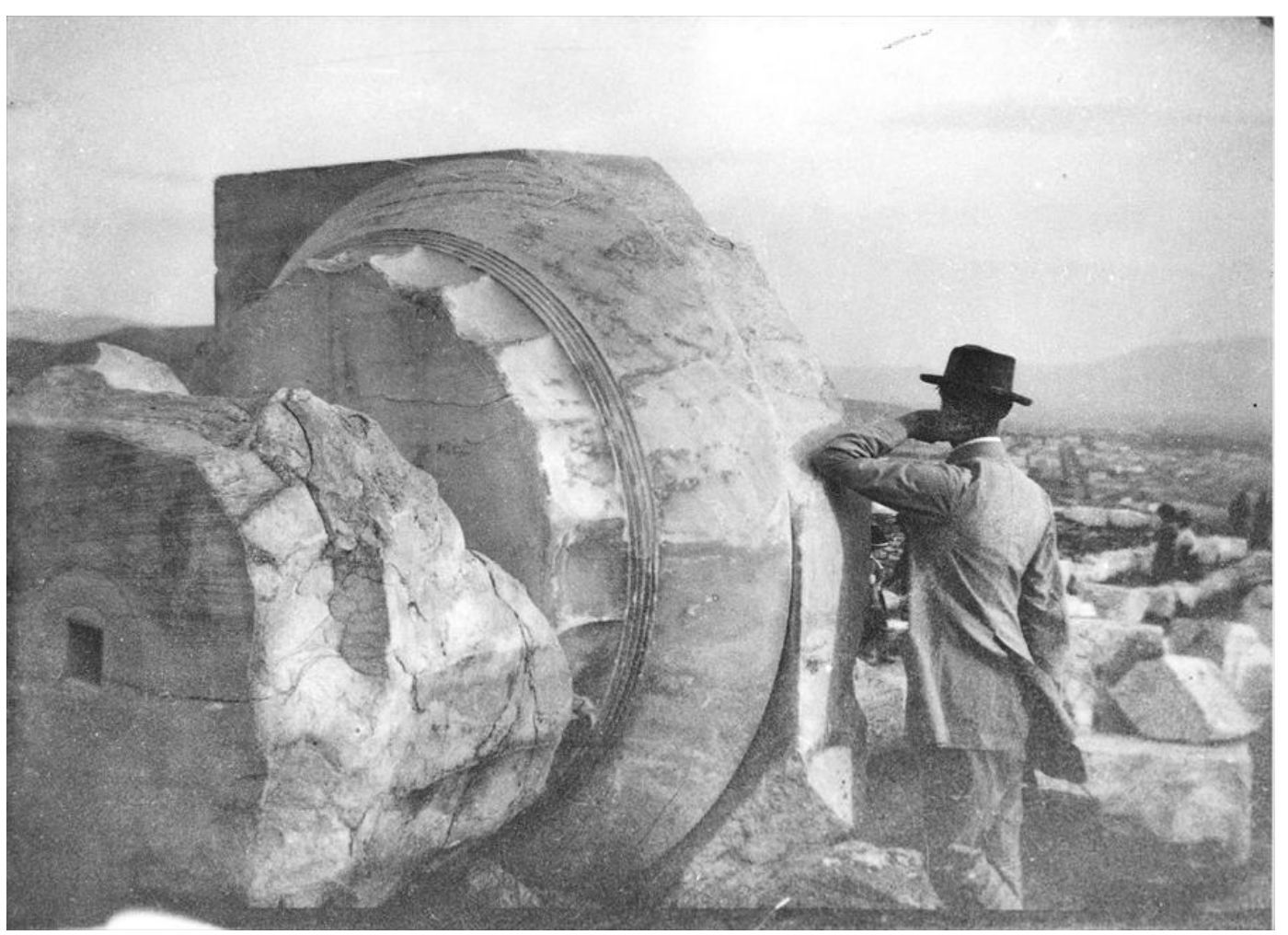

Figura 12: Foto de Le Corbusier em viagem ao Oriente. FONTE: Fundação Le Corbusier

viagens, o lugar da arquitetura, que começa a ser enfrentado, como questão na primeira viagem e é citada como uma preocupação em suas correspondências, Le Corbusier passa a entender a arquitetura como parte de algo maior, do "Universo" e a pensar a "Harmonia" contida nele, como medida de uma ordem que está na natureza. A arquitetura, segundo esse pensamento, seria uma manifestação dessa ordem.

Harmonia em acordo perfeito com a natureza e o universo [...] nos conduz a supor uma unidade de gestão no universo, admitir uma vontade única na origem [...] esse espírito de arquitetura que é uma exteriorização manifesta das leis da natureza. (LE CORBUSIER, 2007)

Le Corbusier entendia que na arquitetura e na arte, os recursos abstratos traduzem as leis da natureza, os recursos são a geometria, a axialidade, a horizontalidade:

Uma geometria elementar disciplina as massas: o quadrado, o cubo, a esfera. Em planta, é um complexo retangular cujo eixo é único. A irradiação dos eixos de todas as mesquitas, em terras muçulmanas, em direção à pedra negra da Caaba é um grandioso símbolo da unidade da fé [...] 0 santuário branco eleva seus 
domos sobre grandes cubos de alvenaria, em sua cidade de pedra. Acredito que a horizontalidade do sempre mesmo horizonte e, sobretudo em pleno meio-dia, a uniformidade imponente dos materiais percebidos instalam em cada um a medida mais humanamente perceptível do absoluto[...] o espírito de arquitetura que é uma exteriorização manifesta das leis da natureza. (LE CORBUSIER, 2007)

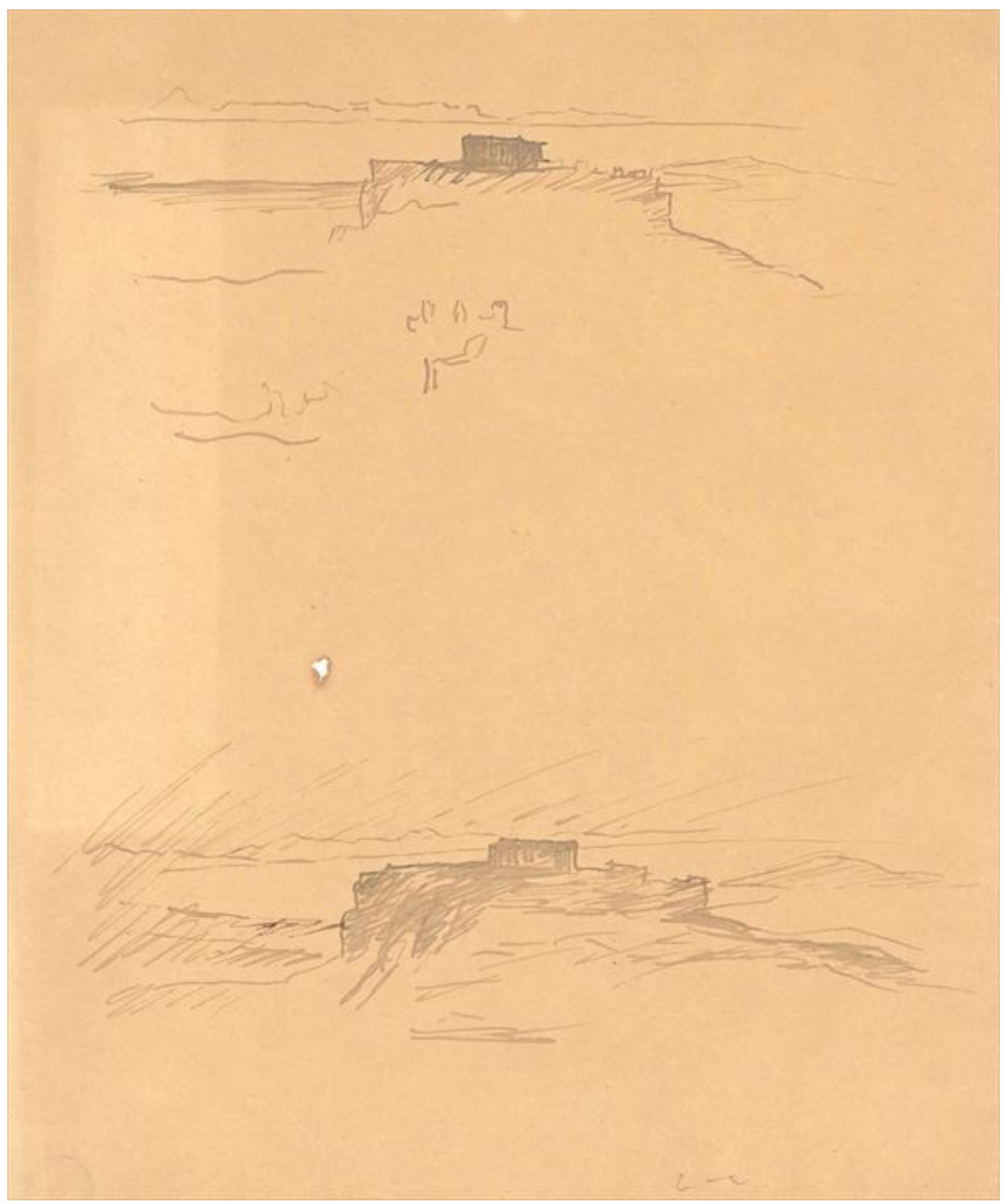

Figura 13: LE CORBUSIER, 1910-1911.

croqui viagem ao oriente. FONTE:

Fundação Le Corbusier. 
A obra que lhe chama a atenção, por conter a evidência do essencial, pela uniformidade dos materiais, é o Parthenon. O Parthenon representa, segundo Le Corbusier, o ponto culminante, sintético, em que o despertou para a visão da arquitetura como manifestação das leis da natureza.

A atitude do viajante ao construir o registro se sua viagem pode nos informar, para além dos eventos da mesma, e é justamente nesse ponto que reside o interesse no material produzido ao longo das viagens.

Viagens e viajantes, especialmente do tipo que tratamos nessa pesquisa, deixam registros, fragmentos que contém informações sobre os espaços visitados, sobre uma época, mas são, para além de seu caráter informacional, objetos de representação, que podem ser lidos em sua fatura, como narrativas da biografia de quem os produziu.

Importa-nos sobretudo refletir sobre a atitude do viajante, do início ao fim da sua viagem. Como partimos principalmente dos relatos de viagens, a própria construção da sua narrativa é não apenas um momento importante da nossa reflexão, mas um de seus objetos centrais. (OLIVEIRA, 1995)

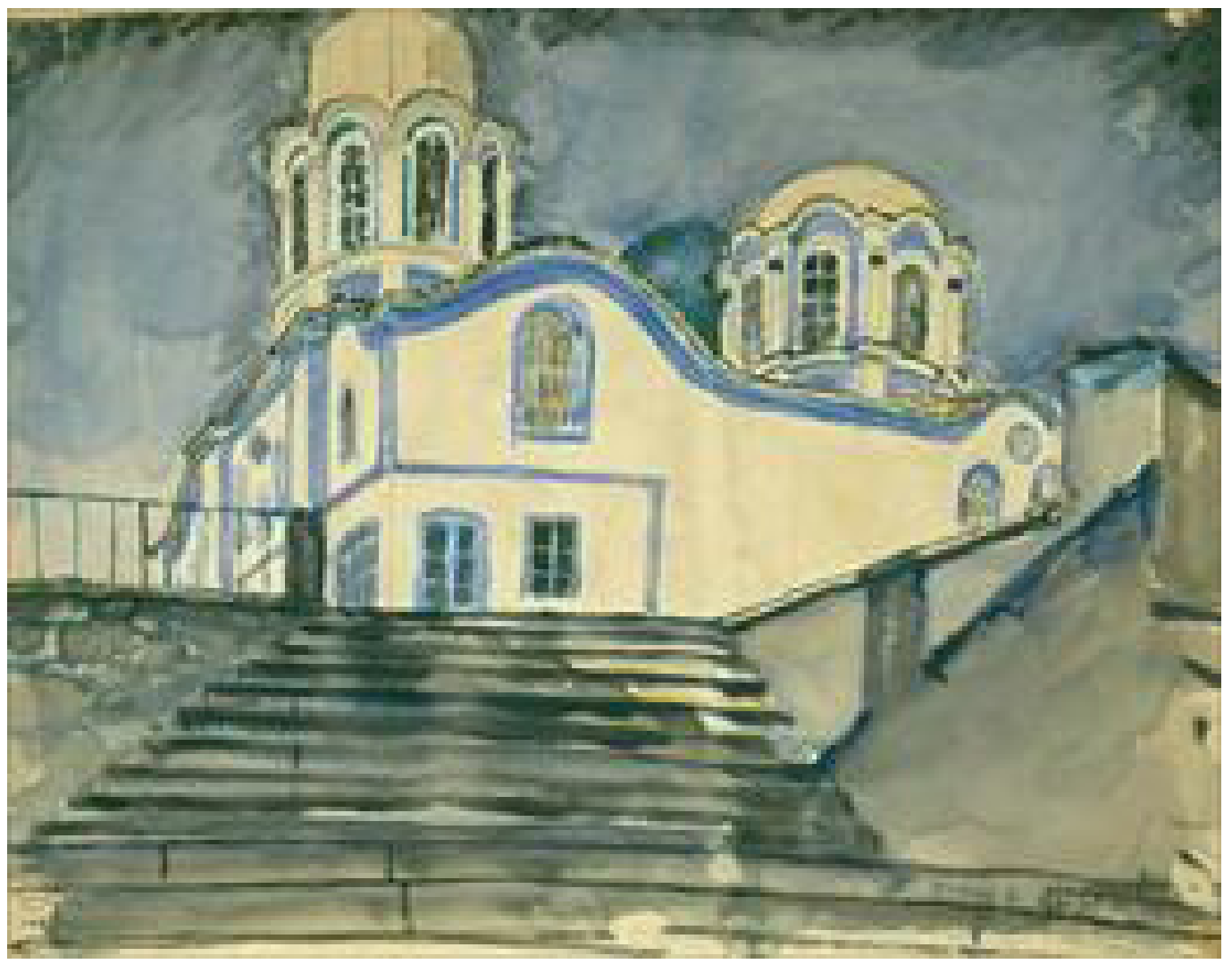

Figura 14: LE CORBUSIER, 1910-1911. aquarela viagem ao oriente. FONTE: Fundação Le Corbusier. 


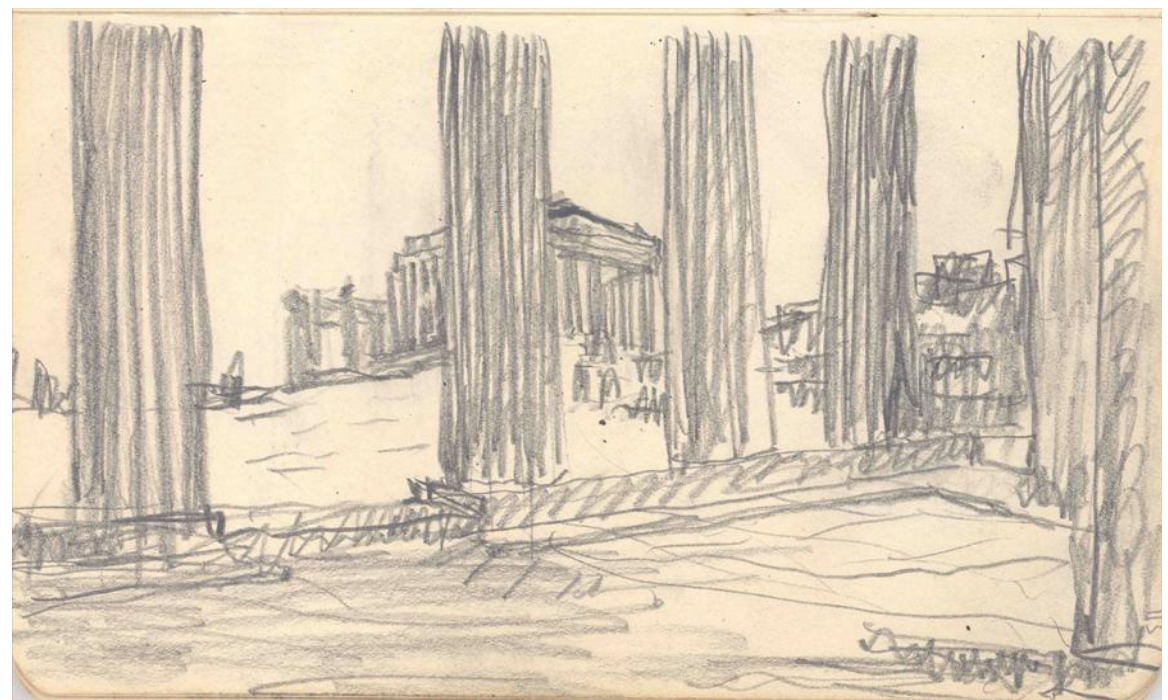

Figura 15: LE CORBUSIER, 1910-1911. croqui

viagem ao oriente. FONTE: Fundação Le

Corbusier.

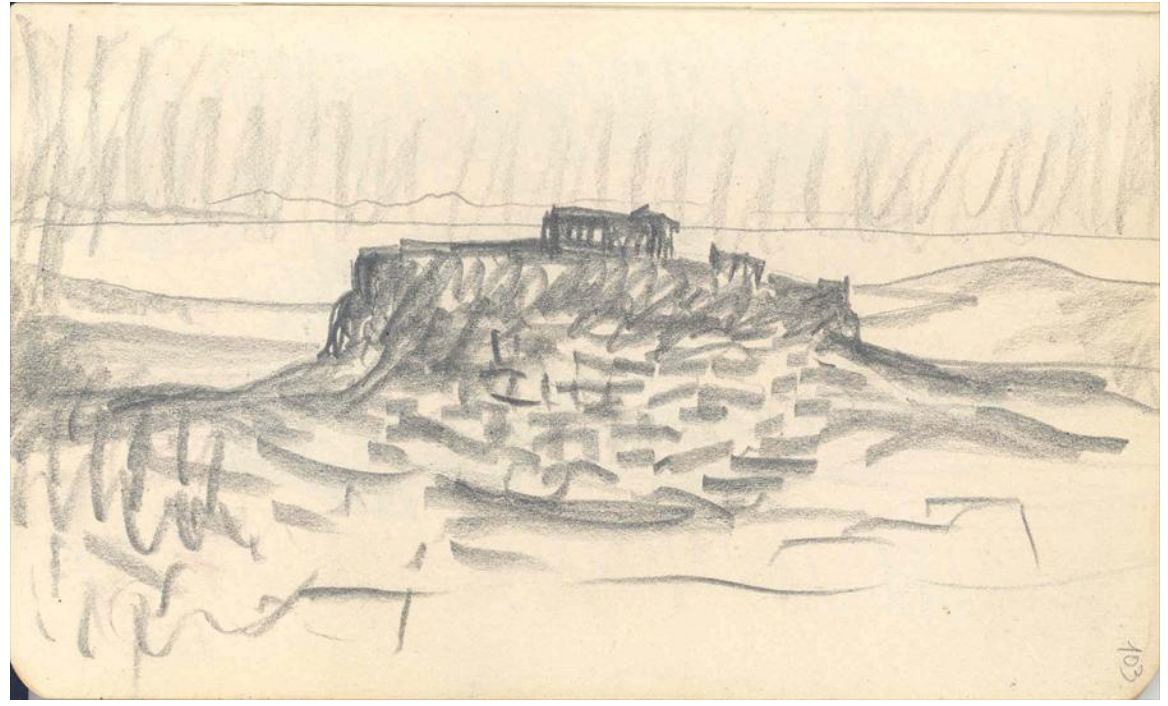

Figura 16: LE CORBUSIER, 1910-1911. croqui viagem ao oriente. FONTE: Fundação Le Corbusier.

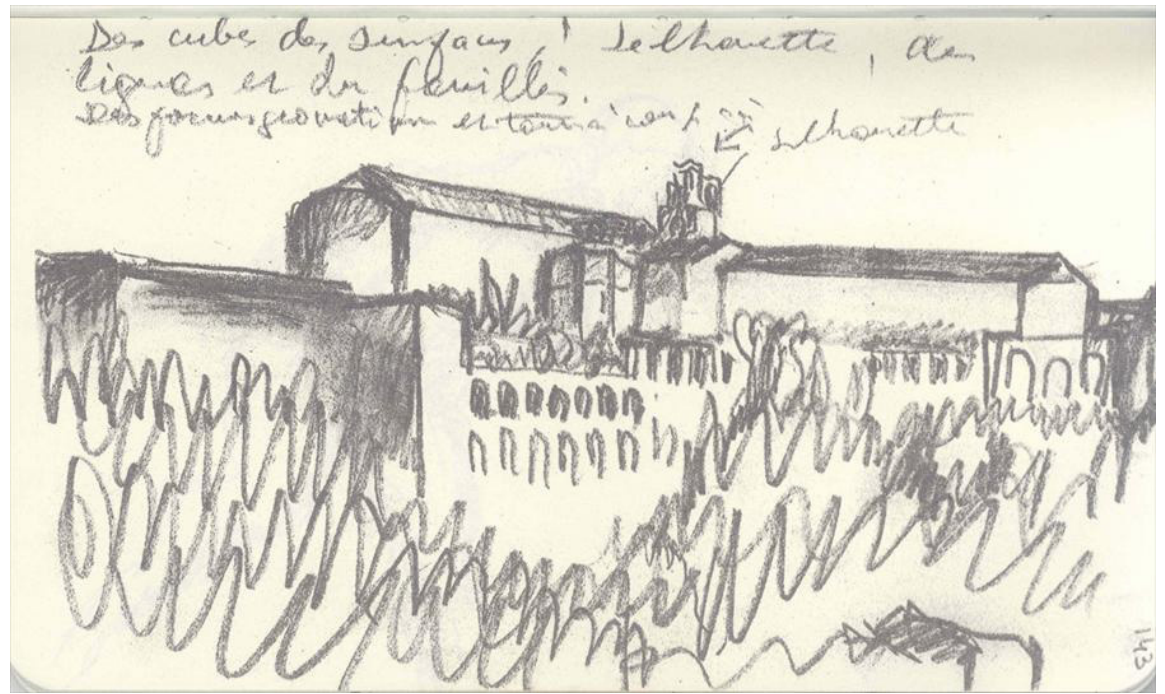

Figura 17: LE CORBUSIER. 1910-1911.croqui

viagem ao oriente. FONTE: Fundação Le Corbusier. 
As viagens de Le Corbusier começaram com uma estrutura muito próxima da programação clássica dos "grand tours", mas considerando o tempo e o amadurecimento do viajante arquiteto, o modo de apreender o espaço foi se transformando, e o novo modo de anotar o que era visto sugere a ansiedade vivida pelo viajante, em captar a essência dos edifícios, a ansiedade em projetar a partir de alguns indícios contidos nas obras. Nesse sentido, a natureza do desenho de Le Corbusier se torna, então, um desenho investigativo.

Sobre o comportamento insistente de Le Corbusier em anotar as impressões e pensamentos em desenhos em seus "carnets", no período compreendido entre 1914 e 1964, KRUSTRUP"13 conclui: "o método que Jeanneret desenvolve em sua viagem ao oriente se transforma no instrumento de toda uma vida".

Essa reflexão é o que orienta a abordagem dessa pesquisa, nos casos que serão apresentados a seguir, nas viagens brasileiras, e mais especificamente, na biografia de quatros personagens.

13 KRUSTRUP conclui, em seu texto: "Tutto è questione di perseveranza, lavoro e di coraggi", referente ao método que Le Corbusier desenvolve nos registros de sua viagem ao Oriente. 
CAPÍTULO DOIS VIAGENS BRĀSILEIRAS 




\section{_olhares sobre o Brasil}

O que se encontra no começo histórico das coisas não é a identidade ainda preservada da origem - é a discórdia entre as coisas, é o disparate. (FOUCAULT, 2014, p.18)

A aparente obsessão pela "pesquisa de origem", como definiu Flora Süsssekind (1990), em seu ensaio - “O Brasil não é longe daqui - O narrador, a viagem", parece se expandir por todos os campos da cultura, não ficando restrito ao literário. Podemos perceber, percorrendo a história das viagens de exploração, e de formação pelo Brasil, desde seus primeiros indícios, que o anseio por caracterizar uma brasilidade pode ser interpretado à luz da observação de Foucault. 0 que estaria por trás da questão da identidade, da criação de marcos, é a ambiguidade que está no cerne da questão da pesquisa de origem no modernismo brasileiro, pesquisa que foi de forma ou outra, realizada ao longo de todas as viagens brasileiras.

0 movimento moderno no Brasil tem questões e particularidades próprias, como debatido por grande parte da crítica de arquitetura. No âmbito da conformação de nosso tema, existe uma questão peculiar em relação à direção que as investidas de modernização e renovação das artes seguiu, se comparada a outros países e em especial à Europa, em que as vanguardas artísticas e a arquitetura se pretendiam ser universal. A ambiguidade, aqui consiste, então, no reforço, ou na busca de uma potencial matriz nacional inicial, que permeou o desenvolvimento desse movimento no Brasil.

Uma sequência de transformações na prática da viagem vem sendo observada desde a passagem das primeiras incursões de aspecto catalogador, colonizador, estrangeiro para as experiências de estudantes brasileiros na matriz clássica, acadêmica. Começa-se a anunciar algumas mudanças de foco, de observador, de itinerários e porque não de invenção de origens, segundo interesses específicos de cada época.

É no contexto do modernismo que essas mudanças ficam mais evidentes, e as viagens e os viajantes parecem ter, antes de partir, uma proposta clara, sobre aquilo que buscam, o desejo é encontrar no passado cultural do país, respostas para as questões da identidade nacional nas artes, na música, na arquitetura. 


\section{_primeiros viajantes}

É sabido que, antes mesmo das viagens dos modernistas, tema central desse trabalho, houve no Brasil uma grande quantidade de viagens, com diferentes objetivos, com outro caráter que não aquele vinculado à pesquisa modernista em torno do caráter nacional que começamos a observar a partir da década de 1920 .

Essas primeiras viagens datam do século XVIII e XIX. Os primeiros viajantes dos quais falamos tratam-se todos de estrangeiros, que se colocaram como intérpretes do Brasil, um país novo, em formação.

Esse olhar estrangeiro debruçado sobre o Brasil produziu diversas narrativas. BELUZZO (1996) atenta para a importância das narrativas de viagem como fonte para a História. As narrativas dos viajantes trazem novos pontos de vista, podendo completar eventuais lacunas na historiografia.

É a partir dessa possibilidade, e atentando para o período histórico e contexto cultural que:

0 interesse contemporâneo no reexame da contribuição dos viajantes que passaram pelo Brasil é um reconhecimento de que eles escreveram páginas fundamentais de uma história que nos diz respeito. 0 legado iconográfico e a literatura de viagem dos cronistas europeus trazem sempre a possibilidade de novas aproximações com a história do Brasil. (BELUZZO, 1996, p.10)

Olhando para a História do Brasil, as viagens foram realizadas por estrangeiros, viajantes de outras nacionalidades que, nesse momento, olharam pra o país de uma perspectiva de documentação, de contar o que havia no território considerado até então "novo", no âmbito europeu ocidental.

Nessas primeiras viagens, o ponto de vista do viajante enquanto estrangeiro e portanto pertencente a outras culturas e dotado de bagagens próprias à elas, são importantes para interpretar o tipo de narrativa que cada um deles construiu e quais eram as motivações por detrás de cada uma delas.

As obras configuradas pelos viajantes engendram uma história de pontos de vista, de distâncias entre modos de observação, de triangulações do olhar. Mais do que a vida e a paisagem americana, exigem que se focalize a espessa camada da representação. (BELUZZO, 1996, p.10)

A camada da representação fala mais de versões do que de fatos. A questão de como uma cultura observa e caracteriza a outra, e como ela mesma se denota aparece nas escolhas representativas que ela faz ao narrar ou relatar uma viagem. 
Quanto às finalidades das viagens que selecionamos para essa primeira exploração e as suas peculiaridades, a condição do Brasil enquanto colônia portuguesa explica parte do caráter dos relatos e principalmente a condução controlada do processo de sua divulgação.

Enquanto Amerigo Vespucci conta haver atingido um mundo novo, Cristóbal Colón pensa ter chegado a um paraíso bíblico. Já a carta de Caminha, primeira resenha da Terra de Vera Cruz, não tem a chance de agir sobre a imaginação européia do século do descobrimento. 0 texto do cronista que acompanha Cabral só será publicado em 1817. A visão ocultada é condizente com o sigilo português e contrasta com a visibilidade dada à América por outros conquistadores. (BELUZZO, 1996, p.10)

Trata-se de uma questão de prática e estratégia que acontece nos primeiros relatos, por vezes nota-se que existem distorção entre aquilo que é observado e o que é descrito, e em outras, algumas informações e detalhes são ocultados.

As primeiras imagens produzidas pelos relatos de viajantes estrangeiros sobre o Brasil eram difundidas em forma de folhetim, que circulavam pela Europa, o desconhecido preenchia o imaginário dos europeus por meio das ilustrações. Outra forma é também a transcrição dos textos das viagens por meio das ilustrações. Essas imagens eram carregadas de um sentido quase sempre religioso, mítico.

A partir do entendimento pelos europeus da noção de antiguidade e "novo mundo", o que é rebatido na narração do Brasil é semelhante ao que ocorre com o restante da América, dentro da lógica dos descobrimentos.

A forma como as imagens que representavam, narravam o "novo mundo" na Europa portuguesa, foi contaminada a todo momento pelas crenças e tradições religiosas e culturais portuguesas, da ética cristã.

Os sinais da religião mostram-se o elo que congrega o habitante das terras distantes nos valores da cultura européia. Se o recurso utilizado parecia aos portugueses procedimento dignificante, era a mais completa negação da cultura indígena, prenúncio do domínio pela catequese dos selvagens e de sua introdução em valores do cristianismo. A acolhida e a assimilação do novo personagem internacional, nos termos de uma relação de identidade pela qual o índio é considerado igual, têm contraditoriamente o efeito de descaracterizá-lo. (BELUZZO, 1996, p.11)

As representações possuíam alto teor simbólico, faziam uso das técnicas pictóricas conhecidas na Europa e dos códigos que podiam ser decifráveis, 
determinando que "[...] a representação possa se dissolver para exibir todo seu teor ficcional." (BELUZZO, 1996, p.13).

A projeção dos desejos das coisas observadas no novo mundo, segundo BELUZZO (1996), aconteceram por duas vias, que o autor descreve:

Com a descoberta do novo continente - novo, para europeus -, eles vêem-se obrigados a repensar a própria cultura e rever as bases sobre as quais erguiam sua visão de mundo. De uma maneira geral, as primeiras imagens das terras brasileiras correspondem a dois impulsos. De um lado, a projeção sobre o desconhecido, os símbolos e mitos, os contos maravilhosos e as fábulas. De outro, a observação direta e o cálculo, que proporcionam descrições geográficas na forma cartográfica, de cartas náuticas a roteiros de conquista, pelos quais se definem domínios e limites entre terra e mar, e nas quais a representação é um meio de orientar a ação. De um lado, a construção simbólica mais vaga. De outro, a precisão do desenho que defende o navegador da geografia fantástica. Contudo, forma poética e ação política sempre estão combinadas nesse amálgama, que é a imagem. (BELUZZO, 1996, p.15)

Uma diferença importante do modo como o Brasil e os brasileiros foram representados nas primeiras viagens e como ela própria vai ser transformada mais tarde na visão dos viajantes modernos é o protagonismo e o foco narrativo, que nas primeiras expedições, era muito dominado pela visão estrangeira:

$\mathrm{Na}$ iconografia e na crônica de autores viajantes nem sempre chegamos a protagonistas. Somos vistos, sem nos termos feito visíveis. Fomos pensados. Ainda assim, essas visões alimentam lembranças do passado e povoam o nosso inconsciente. (BELUZZO, 1996, p.15)

Outra característica que define o tom dessas denominadas primeiras viagens é o predomino da vertente naturalista nas observações, objetivador, científico:

Nas descrições do país encontrado tardiamente pelos europeus, não faltam ícones da "natureza" e é grande a freqüência com que os viajantes observadores da quarta parte do mundo, ainda desconhecido, mencionam as "coisas da natureza" e se sentem atraídos pelos animais e vegetação estranha e exótica. (BELUZZO, 1996, p.16) 


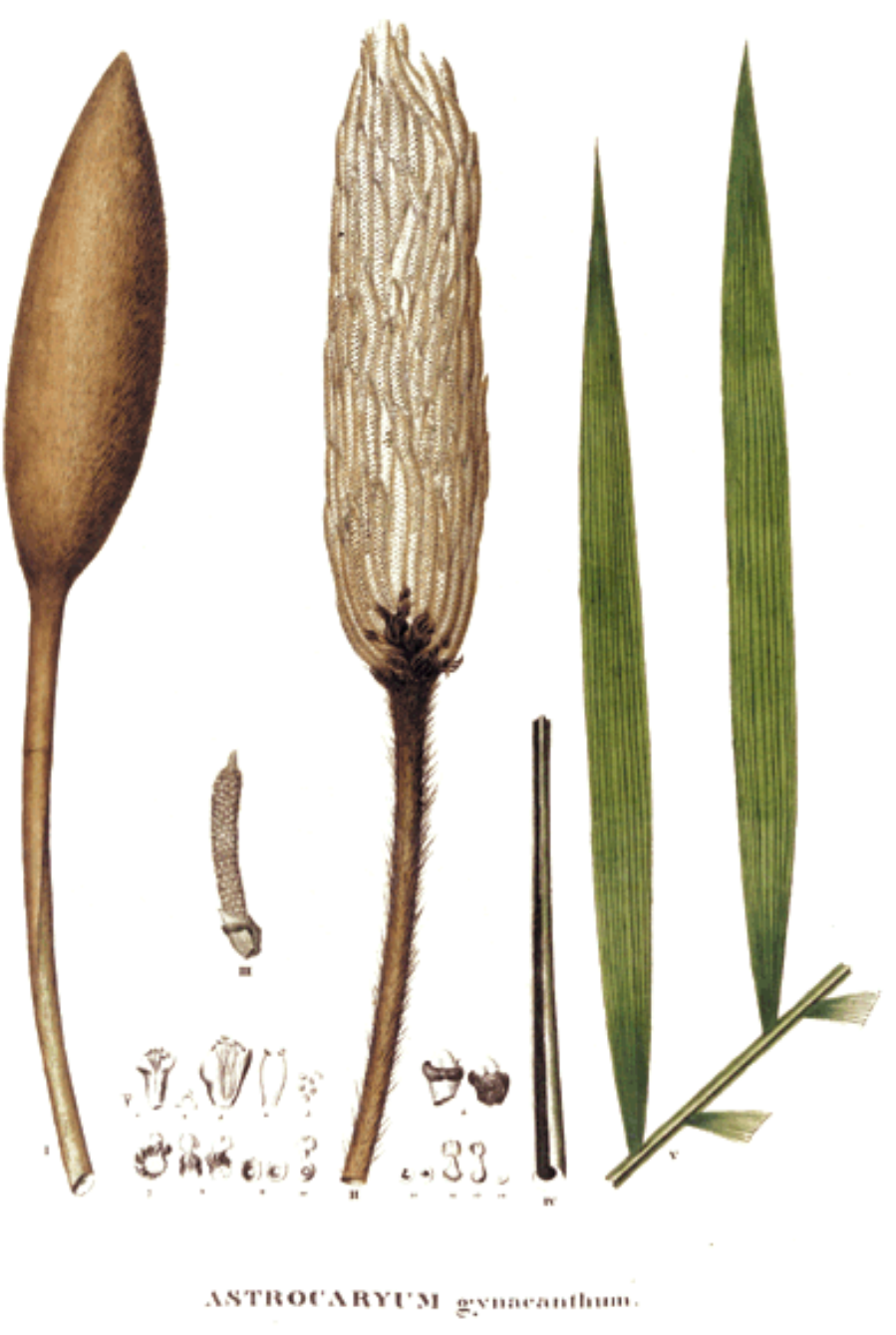

Figura 18: MARTIUS. Detalhes morfológicos das espécies botânicas. FONTE: KURY.

Esse predomínio da visão naturalista sobre o território visitado ainda vinha carregado, em algumas representações, de idealizações acerca do que era a vida na floresta, do mito do "bom selvagem ${ }^{14 " . ~}$

No século XIX, as idealizações paradisíacas, visões da floresta frequentada pelo homem "natural", são novamente revividas por artistas românticos, em reedições dos mitos de origem. No curso de quatro séculos, a visão territorial e a paisagem impõem-se como representações privilegiadas. (BELUZZO, 1996, p.16)

14 O mito do bom selvagem corresponde ao conceito desenvolvido na obra do filósofo franco-suíço Jean-Jacques Rousseau, no qual o homem seria puro, inocente quando isolado na natureza. 
Essas representações privilegiadas da natureza das quais se fala, quando eram divulgadas no continente europeu, acabavam por disseminar e construir um imaginário romântico da América, por exemplo.

É nesse contexto dos séculos XVII e XVIII que o tema do natural ganha preponderância e fama com o projeto enciclopédico, a prática da ciência se concentrava em agrupar os seres, dividir em ordens científicas, de acordo com regras universais.

Essa abordagem prática da ciência a partir das viagens gerou uma discussão acerca das práticas científicas, dos hiatos entre viajantes naturalistas que percorriam longos deslocamentos versus os cientistas que trabalhavam longe do objeto de estudo, onde os primeiros reivindicavam pra si a autenticidade da experiência "in loco" e sua contribuição para a ciência.

Havia, simultaneamente, outra abordagem mais sensível da paisagem, que também aparece como uma preocupação dos viajantes daquele momento quando das viagens em território brasileiro.

Finalmente, o tema indissociável da experiência do viajante do século XIX é a paisagem. Com a vinda da corte portuguesa para o Brasil, especialmente após a independência, chegam ao país artistas profissionais, diletantes com domínio do desenho. Ancoram no Rio de Janeiro passageiros de viagens turísticas pelo mundo. Possuem uma visão educada na estética do pitoresco e buscam desfrutar paisagens características. Mais do que a descrição naturalista, predominam entre eles a abordagem romântica do passeio pelos arredores e pelos jardins, a visão do homem "original" na floresta virgem ou a forte sensação da grandiosidade do universo. (BELUZZO, 1996, p.17)

A discussão sobre o que é paisagem começa a aparecer nos debates que pretendiam tipificar uma paisagem brasileira. Segundo Kury (2001), o exemplo mais conhecido do viajante para quem a experiência da viagem foi insubstituível foi Alexander von Humboldt. Na citação, o viajante:

Defende que impressões estéticas experimentadas pelo viajante em cada região fazem parte da própria atividade científica e não podem ser substituídas por descrições ou amostras destacadas dos lugares onde foram coletadas. (KURY, 2001, p.865)

Outros viajantes naturalistas que percorreram o Brasil nessa mesma época, Martius e Auguste de Saint-Hilaire foram influenciados pelas recomendações humboldtianas, e optando pela viagem como prática de conhecimento:

[...] queriam "ver com os próprios olhos". Porém, cabia a eles transformar sensações, experiências e seres vivos em novas 
espécies de animais e plantas que se encaixassem na ordem natural das famílias, em herbários, animais empalhados, bichinhos imersos em álcool, descrições detalhadas escritas de modo inteligível em cadernos de viagens etc. (KURY, 2001, p.865)

A partir de algumas contribuições e casos que tiveram bastante repercussão na Europa, como dos viajantes descritos anteriormente, "A viagem é em geral considerada pela história natural como uma das etapas necessárias para a transformação da natureza em ciência."(KURY, 2001, p.865)

0 modelo de Humboldt atestou não somente a validade científica e inovadora da viagem, em âmbito naturalista, mas começa a valorizar o elemento sensível que a experiência do território provoca nos viajantes e em seus relatos.

A obra de Humboldt sobre o Novo Mundo e sua aura de grande sábio são referência constante para seus contemporâneos que vieram ao Brasil. A arte expressão privilegiada para dar conta das sensações visuais experimentadas pelos viajantes acompanha sempre que possível os relatos e descrições feitos por naturalistas. (KURY, 2001, p.865)

Um exemplo de viajante que fez o itinerário intelectual pela via humboldtiana foi o botânico Carl Philipp von Martius, um dos mais importantes que visitou o Brasil, Martius, "Além de produzir classificações precisas, numerosos herbários e trabalhos em antropologia e história, esse naturalista descreveu com sensibilidade diversas fisionomias vegetais presentes no Brasil." (KURY, 2001, p.865)

Martius publica seus relatos volumosamente, adotando o formato de prancha e completados por textos. Algumas das publicações são: "Flora Brasiliensis", de 1840 e "Icones Selectae Plantarum Cryptogamicarum", datado entre 1828 e 1834 .

O primeiro volume de sua Flora Brasiliensis, de 1840, contém mais de cinqüenta pranchas que buscam retratar a variedade da vegetação, do relevo e da fauna do Brasil. Uma das imagens do Icones Selectae Plantarum Cryptogamicarum (1828-34) retrata um conjunto vegetal em que, não fosse à legenda a distinguir indivíduos em meio a uma floresta, um olhar inadvertido jamais localizaria as espécies representadas. (KURY, 2001, p.865)

É mais difícil retratar o caráter das jovens florestas brasileiras com palavras do que com imagens; e desse modo parece-nos já ter satisfeito ao benévolo leitor com a arte do pintor. Contudo aquele que deseje saber mais sobre a natureza destas florestas, percorra 
a narração de nossa viagem e o nosso discurso acadêmico sobre a fisionomia das plantas no Brasil.(MARTIUS, 1823, p.73)

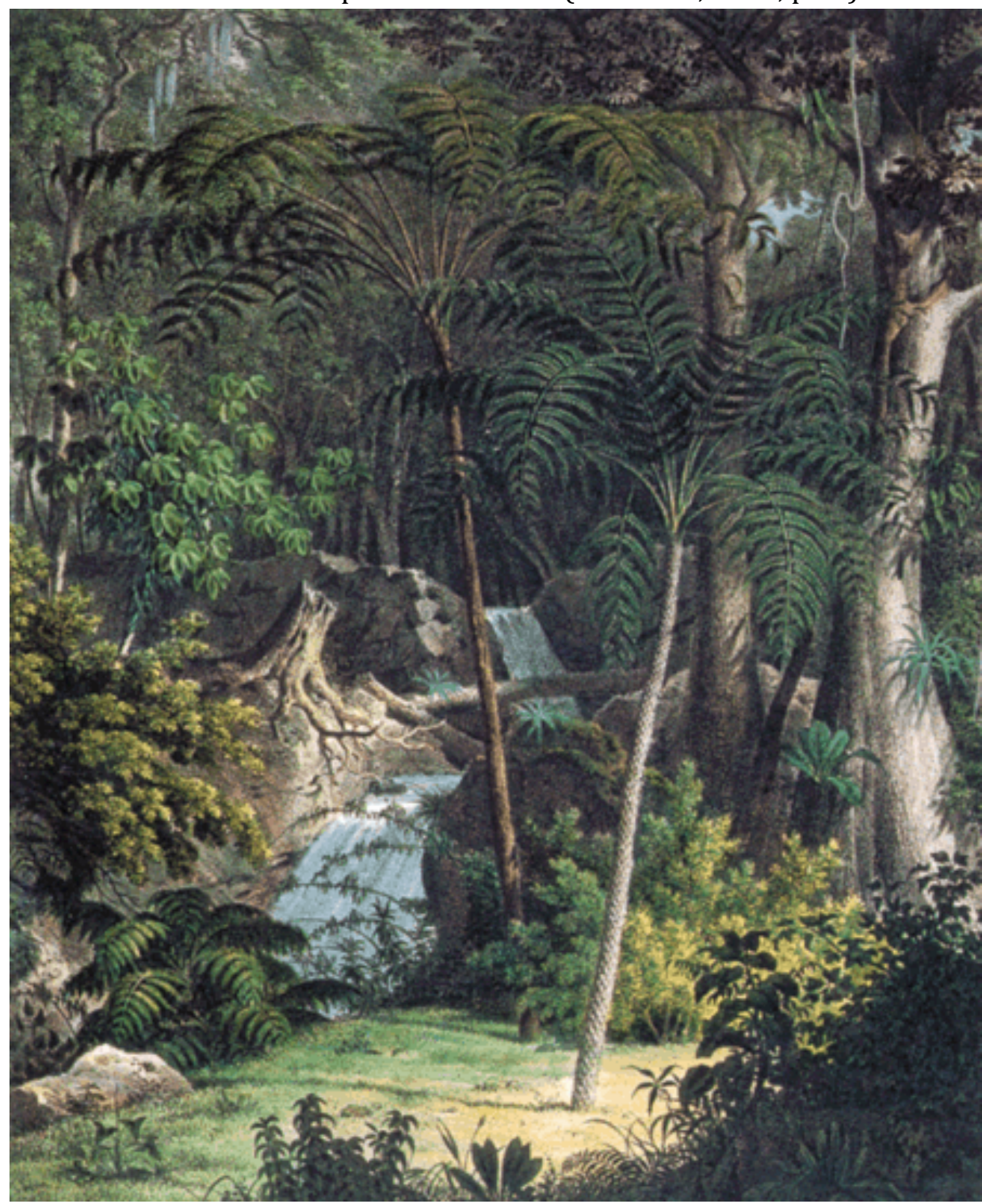

Figura 19: MARTIUS. 1828.Alsophila armata e didymochaena sinuosa na paisagem. FONTE:KURY,

A fala do botânico acerca da sua escolha representativa, com a intenção de divulgar com mais clareza a flora brasileira articula o sentido no conjunto imagem e texto.

Os momentos retratados são especiais, únicos e típicos ao mesmo tempo. Únicos, porque foram vividos e observados pelo próprio viajante ao longo de suas andanças. Típicos, porque os fenômenos descritos ocorrem ali sempre sob as mesmas circunstâncias. A fisionomia de um lugar depende da quantidade, da variedade e da sociabilidade das plantas e dos animais, assim como do tipo de 
relação que os habitantes locais estabeleceram com a natureza ao longo do tempo. É como se cada fisionomia contivesse uma parte da alma do Brasil. (KURY, 2001, P.870)

A ideia de paisagem estava muito atrelada ao conceito de fisionomia, para a identificação das fisionomias existentes por todo o país, os viajantes faziam uso de referências interdisciplinares, na geografia, na literatura, na pintura.

$\mathrm{O}$ discurso acadêmico ao qual ele fez referência-A fisionomia do reino vegetal, de 1824 - descreve as diversas fisionomias que compõem o país. 0 Brasil é definido como um todo geográfico, delimitado pelo mar e por dois grandes rios: o da Prata e o Amazonas. A unidade subjacente a essa região é dada pelas florestas, que dominam grande parte do território. A umidade, a altitude, a proximidade do equador, entre outros fatores, alteram a vegetação e, conseqüentemente, a fisionomia dos lugares. (KURY, 2001, P.867)

A pintura como meio expressivo de representação foi amplamente empregada, por ser sintética e por carregar uma ideia:

A pintura deve também ser portadora de uma 'idéia'. É através desse componente que a representação da Natureza ganha a aureola de um gênero digno das Belas Artes. Com isto, a sua proposta adquire um grande alcance. (DIENER E COSTA, 2008, p.81)

As viagens começam a adquirir também um importante papel para além da descrição de lugares, para o desenvolvimento de disciplinas e de meios de representação:

Para Humboldt, o melhor e mais acabado modelo que pode almejar o pintor de paisagens se encontra no mundo tropical. É ali onde o artista tem de praticar seus estudos acadêmicos. Pois, já com base nos conhecimentos adquiridos nas viagens, é que poderá chegar a uma compenetração profunda com a natureza e, com isso, ultrapassar o simples registro da sua experiência visual, materializada nos croquis e esboços, para ascender a uma formulação na qual, certamente, convergem esses trabalhos preparatórios, contudo já com o fim de compor uma vista que defina o caráter da paisagem. Essa é a idéia que se aglutina a uma obra concluída. Ela resume uma impressão global e oferece uma representação coerente da fisionomia da natureza. A arte deve, além disso, cumprir uma função didática, com o valor de um estímulo para o estudo do mundo natural. Deste modo, a melhor caracterização de uma região será aquela versão que represente 
a paisagem em suas possibilidades ótimas, ou seja, aquela que partindo de esboços realizados em viagem, o artista crie no seu retorno. (DIENER E COSTA, 2008, p.81)

0 modo coma a pintura final era pensada tinha relação com a teoria de representação do corpo humano no Renascimento, na qual a aglutinação de estudos e modelos para criar o produto final, mais próximo de um ideal, que tivesse esse poder de comunicação do que particularidades observadas de fato. Dessa forma, deveria se memorizar as recorrências para depois reproduzi-las espontaneamente. Essa é a representação fisionômica da natureza, segundo formulação de Humboldt. Havia, ainda nesse modelo, a alegação de que a vivacidade do desenho, possível no enfrentamento com a natureza local, valorizava a experiência visual e corpórea da viagem.

Rugendas, em sua experiência como ilustrador da expedição Langsdorff na viagem para o Brasil no contexto das primeiras expedições ilustra essa relação:

Um terceiro caso que sensibilizaria especialmente ao viajante alemão neste assunto, foi o de Johann Moritz Rugendas, o mais prolífero dos artistas que Humboldt protegeu. Rugendas havia passado quase quatro anos no Brasil (de 1822 a 1825), como ilustrador da expedição capitaneada por Georg Heinrich von Langsdorff. (DIENER E COSTA, 2008, p.85)

0 modelo humboldtiano pode ser entendido na medida em que os viajantes:

Deslocando-se solitários ou em expedições naturalistas, estes artistas costumavam apreender os diferentes lugares com suas paisagens naturais e urbanas, tipos humanos, ritos de vida, enfim tudo que coubesse nas pequenas folhas de suas cadernetas de bolso, os carnet de Voyage, ou nas suas pastas de desenhos. Era ali que, a lápis, a aquarela e mesmo a óleo, o viajante registrava em primeira mão as impressões que os lugares lhes causavam. Entretanto, a obra propriamente tal só seria elaborada depois, em outro momento, geralmente no retorno. (DIENER E COSTA, 2008, p.78)

A experiência do corpo, em sua totalidade, em viagem se dá pela enorme quantidade de fenômenos que são percebidos, e a representação almeja dar conta de informar sobre essas sensações, sobre essa variedade, nesse sentido: A iconografia e os relatos de viagem buscam, assim, descrever de modo exaustivo e profundo os diversos elementos que compõem cada lugar. Esse aspecto do trabalho científico dos naturalistas do 
século XIX pode parecer, aos leitores do século XX, meramente 'pitoresco' ou 'romântico', no sentido pejorativo que a palavra adquiriu. No século XXI, para rejeitar os possíveis anacronismos interpretativos, é preciso compreender que, para os naturalistas do século XIX, a ciência devia buscar descrever a totalidade de elementos que atuavam em um fenômeno local. É como se cada parte contivesse o todo. Uma fisionomia particular seguiria a mesma lógica de relações harmônicas e de simpatias que, supunha-se, regiam a vida cósmica. (KURY, 2001, p.870)

Os meios perceptivos pelos quais os viajantes passam a experimentar a viagem são compreendidos na totalidade e multiplicidade das sensações, de forma fenomenológica.

Para grande parte dos naturalistas do século XIX, a multiplicidade de sensações que envolvem o naturalista em sua viagem poderia e deveria ser descrita pela ciência. Daí o uso de representações pictóricas e a preocupação com os recursos literários das narrativas de viagem. Assim, o cientista que se fez viajante escolheu não apenas ver com os próprios olhos, mas ouvir e sentir com o próprio corpo os fenômenos lá onde acontecem. Talvez resida aí uma das hesitações da ciência romântica, já que, se por um lado o viajante romântico produzia ciência in loco, por outro, acabou se especializando no registro preciso de sensações e fenômenos, em consonância com os métodos científicos estabelecidos na época. (KURY, 2001, p.870)

O estilo pitoresco nas representações também foi apontado como escolha representativa dos artistas-viajantes do momento naturalista.

Nas expedições do Século das Luzes os lápis e pincéis eram manejados por ilustradores, documentadores. Cabia a estes a função de levar ao papel as imagens que botânicos, geógrafos, zoólogos e demais cientistas das expedições lhes indicassem. À obra do documentador não se atribuía um valor por si mesma; era uma complementação, mas essencial, à grande catalogação que os circunavegadores realizavam. Será no início do Oitocentos que este personagem vai se metamorfosear em artista. Mesmo que ainda o encontremos no interior de empresas científicas, mais e mais vão surgindo figuras que solitárias, ou ocasionalmente, em pares, viajam pelo prazer de ver e registrar, a partir de suas próprias motivações. Embora ainda não se soubesse, ali estavam os artistas-viajantes. (DIENER E COSTA, 2008, p.76)

Em relação à problemática da divulgação e do uso das informações que 
os relatos carregavam, e que foram se transformando ao longo das épocas:

Se os relatos de viajantes já vinham ganhando espaço entre os naturalistas e o próprio Estado já em finais do século XVIII por trazerem informações importantes ao desenvolvimento das ciências - e assim, ajudando a desenvolver e a incrementar as finanças do Estado -, nos oitocentos eles ganham ainda mais destaque, uma vez que também servem a uma outra classe de intelectuais, que se fortalecia e que a cada dia ganhava mais espaço junto aos dirigentes do Governo: os historiadores. (BARBATO, 2012, p.05)

Essa discussão faz sentido no contexto do século XIX, no qual a história se firmava como ciência, e prescindia de um conhecimento que era adquirido através de documentos e de seu exame crítico.

No Brasil, a relação entre os materiais produzidos pelos viajantes foram estudados e apropriados de forma política e estratégica, fortemente amparada por meio de instituições, como é o caso do:

[...] Instituto Histórico e Geográfico Brasileiro era o principal representante desse pensamento. Ele fora criado para servir de exemplo para instituições congêneres nas diversas províncias brasileiras4, o que segundo Manoel Guimarães ressalta o caráter iluminista da associação5, já que foi inspirado no modelo adotado na França do século XVIII, no qual as academias científicas e literárias provinciais articulavam-se na teia mais ampla do processo de centralização conduzido pelo Estado, com sede em Paris. (BARBATO, 2012, p.07)

Encontra um desenvolvimento, então, essa vertente diferente das questões que eram caras aos artistas-viajantes. As narrativas de viagem são entendidas em seu potencial estratégico por parte do Estado e organizações ligadas à ele.

[...] as publicações do IHGB valorizam os relatos dos viajantes, e encontra neles pontos importantes para seu projeto: construir uma identidade nacional para o Brasil, ainda carente de laços de união no século XIX e transformá-lo em país civilizado - aos moldes da civilização europeia da época. (BARBATO, 2012, p.09)

Nesse momento, acontece no Brasil, uma preocupação, embrionária, sobre o controle e o uso das informações que continham nos relatos que os viajantes haviam produzido até então. 
As viagens caracterizadas como "viagens acadêmicas" foram assim denominadas por estarem associadas à ideia de uma disciplina, de uma prática, também associada com a prática histórica das viagens clássicas, dos "grand tours" e "prix de rome" e teve desenvolvimento no Brasil no século XIX.

0 "clássico" visitado em viagens do qual se fala é o sentido icônico das obras, do classicismo, que fora recuperado pelos movimentos Renascentista e Iluminista nas artes e na arquitetura, de matriz greco-romana, representando um ideal, ícone que é obrigatório conhecer. Essas viagens partiram de dentro das escolas de formação de artistas e arquitetos, ligadas à matriz francesa.

A semelhança desse tipo de viagem que surgira no Brasil com os clássicos "grand tours" pode ser observada de duas maneiras, uma que é quanto ao formato da viagem, viabilizada a partir de premiações e patrocínios, nas quais os estudantes enviados para essas viagens tinham o objetivo e até a obrigatoriedade de trazer em seus registros, resultados, observações e desenhos. Outro aspecto que as aproxima se refere ao conceito, o que o papel da viagem representava. Nos dois modelos, o "grand tour" europeu e as viagens acadêmicas brasileiras eram endereçados aos mesmos tipos de destinos, cidades, edifícios, paisagens ícones.

Este foi o primeiro momento em que no Brasil, a viagem ganhou uma aura de disciplina, diferentemente do caráter colonizador, que as viagens naturalistas desenharam por aqui nos séculos XVII e XVIII. No contexto brasileiro:

[...] o aparecimento das viagens de estudos, tidas como etapa complementar na formação de artistas e arquitetos, está ligado ao modelo de ensino praticado na Academia de Belas Artes no Rio de Janeiro, instituição muito tributária à matriz francesa, sobretudo no século XIX. Se o sistema francês de formação de artistas determinou a orientação de muitas das academias do mundo ocidental, ele também permitiu a criação de um espaço privilegiado para que os alunos estrangeiros pudessem aperfeiçoar seu aprendizado, fosse tecnicamente, de acordo com os preceitos de sua prática acadêmica, fosse pelo contato direto com seu acervo e obras da tradição clássica. (SODRÉ, 2010, p.53)

Nesse formato acadêmico de viagens, o viajante aprendiz cumpria com uma série de exigências quanto às contribuições que sua viagem deveria trazer para a instituição que providenciara o financiamento, por exemplo. Em linhas gerais funcionava da seguinte maneira:

Uma vez premiado, o aluno seguia para uma temporada de 
estudos na Europa, subvencionado pelo Estado durante toda sua estadia, que geralmente era de três anos. 0 futuro pensionista, em contrapartida, deveria enviar desenhos obrigatórios para avaliação dos professores brasileiros, quase uma prestação de contas com a Academia brasileira das atividades desenvolvidas no exterior. (SODRÉ, 2010, p.53)

Essas viagens tinham algumas especificidades, entre elas o perfil do viajante. A formação era voltada ao desenvolvimento de habilidades artísticas, entre pintores, escultores e alguns arquitetos. Era a viagem clássica ganhando espaço nas escolas brasileiras. Um exemplo de estudante de arquitetura a realizar a viagem foi Antônio Batista da Rocha, que em 1846 vai estudar na L'Académie de France à Rome. Entendia-se que o contato com o clássico iria desenvolver habilidades dos estudantes em formação.

Novamente, se pensarmos na dinâmica pedagógica dessas escolas, o que a escola direcionava como preceito clássico refletia o discurso do pensamento artístico e arquitetônico da época, e nesse sentido, observamos um desprendimento da metodologia clássica a partir da década de 1920 nas escolas, impulsionado pelo contexto cultural do país, pelos movimentos artísticos ascendentes que começavam a ganhar voz dentro das instituições através de professores, patrocinadores.

Nas primeiras décadas do século $\mathrm{XX}$, o ensino de arquitetura no Brasil ainda se mantinha preso aos preceitos clássicos. Inclusive no interior das escolas politécnicas. Na Escola Politécnica de São Paulo, criada em 1894, o curso de engenheiros arquitetos funcionando efetivamente a partir do ano letivo de 1896/97, era inicialmente organizado em três anos de formação após o primeiro ano do curso geral.

Uma mudança nesse horizonte acadêmico francês de referência foi provavelmente introduzida a partir dos anos 20, através de professores como Victor Dubugras (1868-1933) e Alexandre Albuquerque (1880-1940). Professor da Politécnica desde a sua fundação, Dubugras, que desde o século XIX notabilizara-se por suas incursões medievalistas e Art-Nouveau, foi um dos primeiros arquitetos a aderir ao revival colonial, projetando importantes edifícios públicos e privados conforme a moda nacionalista. Albuquerque, por outro lado, foi de fato o responsável pela incorporação definitiva da tendência no âmbito do ensino. (SODRÉ, 2010, p.56)

Em termos de mudanças pedagógicas, dentro das escolas, a partir da 
experiência do professor Alexandre Albuquerque, que faz uma revisão na disciplina "História da Arquitetura. Estética. Estilos", propondo e destacando a importância de se estudar o interior do Brasil, onde as cidades mineiras passaram a fazer parte dos itinerários de viagem do período:

Com Alexandre Albuquerque, aliás, é possível encontrarmos uma mudança de atitude pedagógica em relação às viagens que até então os estudantes realizavam durante seus anos formativos. Formado engenheiro-arquiteto em 1905 e contemplado com prêmio de viagem à Europa no ano seguinte, como professor da escola a partir de 1917, parece ter redefinido a orientação dos estudos sobre arquitetura brasileira entre os estudantes. Ao assumir as cadeiras de "História da Arquitetura. Estética. Estilos" para os segundo e terceiro anos do curso ainda em 1919, passou organizar e acompanhar seus alunos em viagens para cidades como Itanhaém, Ouro Preto, Tiradentes e Congonhas do Campo com o intuito de aperfeiçoar o contato com a arquitetura colonial através de desenhos e levantamentos realizados in loco dos edifícios mais interessantes. Apesar destas "excursões técnicas" não terem suas datas mencionadas, Maria Lucia Bressan Pinheiro acredita que tenham sido realizadas entre os anos de $1921 \mathrm{e}$ 1925, levando-se em conta os anos de formatura de alguns de seus participantes. Tal iniciativa, inclusive, se antecipou em alguns anos às viagens patrocinadas por José Mariano Filho aos jovens arquitetos cariocas para as cidades históricas mineiras. (SODRÉ, 2010, p.57)

É nesse momento de revisão pedagógica que as viagens endereçadas ao território brasileiro, cidades como Ouro Preto, Tiradentes, Congonhas, se transformam nos destinos primordiais da arquitetura colonial, entendida então como a tradição brasileira que deveria ser estudada, investigada, catalogada.

Esse interesse na arquitetura produzida em Minas Gerais no período colonial vem acompanhado de questionamentos de ordem política e cultural que o país vinha enfrentando do começo do século XX.

É como se a partir dessa reforma pedagógica e de perspectiva dentro das escolas, os roteiros de viagem tivessem elegido um novo clássico, alinhados com a narrativa do movimento neocolonial que começara a surgir.

[...] a inversão deliberada do roteiro tradicional da viagem ao exterior tendo em vista um objetivo duplo: renovar a arquitetura brasileira e iniciar o processo de documentação sistemática do patrimônio histórico nacional. (SODRÉ, 2010, p.61) 
Os viajantes passaram a percorrer então novos roteiros, houve, naquele momento, dentro do modelo de viagem que elegia um "clássico" a se visitar, uma inversão, da Europa ao interior do Brasil.

A inversão deste referencial anterior permitiu que outros destinos passassem a ser privilegiados pelos viajantes, muitas vezes dentro de suas próprias fronteiras territoriais, locais ou nacionais. 0 que, no caso especifico do Brasil, os conduziria a edificações e cidades do período colonial. Assim, por mais que as passagens de Nestor de Figueiredo, Nereu Sampaio ou Lucio Costa pelas cidades históricas mineiras, a partir de 1924, todas patrocinadas por José Mariano Filho através da Sociedade Brasileira de Belas Artes, fossem para pesquisar os elementos da nossa arquitetura do passado, a viagem ainda era concebida a partir do registro anterior. Mantinha, desse modo, seu caráter eminentemente didático, voltado para a complementação de uma formação em grande parte tributária da história dos estilos presente nos manuais, tratados, inventários etc., ainda que no caso, o resultado visado não se restringisse à formação individual, mas se alargasse à constituição de um acervo visual alternativo, passível de ser incorporado ao ensino e à prática, uma vez que ausente do repertório acadêmico. 0 que nos interessa assinalar no momento são as significativas alterações pelas quais a representação e a interpretação do Brasil passaram com a ascensão de uma perspectiva modernista da cultura, a partir da década de 1920. Com efeito, as viagens neocoloniais são contemporâneas ao aparecimento de um outro olhar e novas práticas de viagem, nas quais o esforço de desvendamento do país e pesquisa dos elementos nacionais ultrapassava os referenciais tradicionais do meio e da raça em um processo de atualização estética e intelectual da alta cultura. (SODRÉ, 2010, p.69)

Esse período se caracteriza pelas viagens percorridas pelos estudantes ${ }^{15}$ da Escola de Belas Artes durante a década de 20 a Minas Gerais, num anseio de resgate da arquitetura neocolonial brasileira, na lógica dos movimentos tradicionalistas, patrocinados por José Mariano Filho.

Recuperando um pouco do que foi o movimento neocolonial brasileiro, se faz necessário compreender seu principal precursor, Ricardo Severo, engenheiro português que veio atuar no Brasil.

Portugal, no mesmo período, também experimentava uma ânsia

15 Os viajantes eram estudantes de arquitetura Nestor de Figueredo, Nereu de Sampaio e Lucio Costa partem em viagem. 
de busca de identidade, de elementos culturais e tradicionais para afirmação de sua nacionalidade. 0 arquiteto português Raul Lino, conhecido como expoente do movimento da casa portuguesa, era um dos representantes desse universo cultural partilhado por Severo. (MASCARO, 2011)

Com esses paralelos, os dois movimentos apresentaram similaridades, ao se originarem do mesmo ambiente cultural. Ambiente que provocou a preocupação com a tradição, com a arquitetura colonial portuguesa, e, no caso de Severo, esse pensamento se desenvolveu no sentido da busca dessas identidades no Brasil.

0 movimento neocolonial brasileiro foi um movimento em prol da criação de um estilo arquitetônico propriamente brasileiro, que já apontava indícios dentro da Escola Nacional de Belas Artes, aparecendo já desde 1910 e se tornando mais forte a partir de 1920. 0 que veio a ser chamado de estilo, antes foi um movimento artístico de renovação da arquitetura e do ensino, com teóricos, debates, polêmicas, e se formou tanto de influências iluministas, no que diz respeito à dimensão de república que o movimento possuía e também de uma matriz romântica, no interesse pelas tradições, pelo passado colonial do país.

O neocolonial na arquitetura pretendia fornecer bases formais e técnicas da tradição colonial brasileira para a construção de uma arquitetura nova com identidade, condizente com as peculiaridades do país no que diz respeito à luz, clima, tradições e ambiências, em oposição ao ecletismo, corrente que era predominante até então.

Analisando o período pelo contato com o tema das viagens, as incursões que ocorreram no neocolonial iniciam uma discussão que vai se intensificar com o movimento moderno brasileiro, apesar do enfrentamento que o segundo faz com o primeiro, no que tange às mudanças observadas nas práticas das viagens, o movimento neocolonial abre caminhos para procedimentos que serão adotados pelos viajantes modernos.

A questão, para os movimentos eclético, neocolonial e moderno sempre foi a forma da modernidade no Brasil. Parte das respostas que cada movimento apresentou apareceram do enfrentamento que cada um deles travou com as tradições do país. 0 enfrentamento das tradições era um fato recorrente nas viagens dos estudantes, arquitetos, intelectuais em formação que iam pensar cada um dos movimentos, em momentos temporalmente distintos, se revisitaram o mesmo espaço e se fizeram as mesmas questões.

A interpretação dos signos do passado foi o que diferenciou os 
movimentos, mas no campo das viagens, podemos ver continuidades entre as práticas, que se intensificaram e se alinharam com novos conceitos, como o das vanguardas artísticas, a busca pelo popular. Essas interpretações divergentes aconteciam em função da sensibilidade do viajante e do alinhamento com um ou outro projeto estético para o país.

Essa posição assumida pelas escolas, por professores e arquitetos provocou uma diversidade de interpretações era expressa pelos atores dos movimentos eceletista, neocolonial e moderno publicamente, em textos jornalísticos e em discursos acalorados, e o debate provocado por esses embates era uma prática recorrente no Brasil do início dos anos de 1920. Como é o caso das visões de Mário de Andrade e Ricardo Severo:

Se ambos, Mário e Severo, assumiam um compromisso com a independência estética do país, identificando naquela arquitetura pretérita ecos da originalidade que perseguiam, não é possível afirmar que compartilhassem de um mesmo projeto nacional e estético. Mário não compactua do nacionalismo patriótico de Severo, nem de seu atávico lusitanismo, distanciando-se do engenheiro na maneira com que voltava e lia a velha arquitetura colonial e nossa tradição. (SILVA, 2014, p.39)

Esse movimento de interesse pela arquitetura colonial tinha como questão mais abrangente que é o retorno às tradições, nesse contexto, houve um embate entre quem via esse retorno como uma defesa da arquitetura do passado enquanto estilo e quem estava alinhado ao movimento moderno, que via nesse mesmo retorno, uma recuperação dos valores essenciais daquela arte desprovida da ideia de cópia ou idealização.

Porém tal retomada se apresentava entre os modernistas como ruptura. Nota o crítico que, pela pena de autores como Mário de Andrade, entre outros, ocorria a libertação de uma "série de recalques históricos, sociais eétnicos", pois havia, em nossa cultura, "uma ambiguidade fundamental: a de sermos um povo latino, de herança cultural europeia, mas etnicamente mestiço, situado no trópico, influenciado por culturas primitivas, ameríndias e africanas. Esta ambiguidade [dava] sempre às afirmações particularistas um tom de constrangimento que geralmente se resolvia pela idealização". o modernismo rompe com isso, e "as nossas deficiências, supostas ou reais, são reinterpretadas como superioridades. [...] 0 primitivismo é agora fonte de beleza e não mais empecilho à elaboração da cultura. Isso na literatura, na pintura, na música, nas ciências do homem" (CANDIDO, 2000, p. 
119-120) e, poderíamos acrescentar, recuperando as diferenças entre Severo e Mário de Andrade, também na arquitetura. (SILVA, 2014, p.39)

O debate acerca da formação da arquitetura moderna brasileira no início dos anos de 1920, entre os atores do neocolonial e do modernismo fala da complexidade e ambiguidade que a retomada das tradições provocava e seus desdobramentos:

As coincidências e divergências entre os discursos destes engenheiros, arquitetos, artistas, escritores e intelectuais, reforça a complexidade e a ambigüidade do debate acerca do moderno e do nacional no Brasil em curso na primeiras décadas do século XX. Em sua trajetória, Severo parece justamente sintetizar e exibir lados e versões conflitantes naquele momento, aproximando a partir das noções de tradição, nação e modernização artística, movimentos que a princípio estariam em lados radicalmente opostos como o ecletismo, o neocolonial e o moderno, ou agentes tão distantes como os intelectuais do Instituto Histórico e Geográfico - que acolhem com entusiasmo suas idéias- e os modernistas paulistanos - que num primeiro momento o aclamam, para depois o criticarem. Se é possível perceber, por um lado, o quanto o moderno e o modernismo naquele momento reivindicam o novo e uma nova forma de falar sobre o Brasil beneficiando-se surpreendentemente de idéias e sugestões caras ao século XIX - como as de tradição e evolução, apenas para citar duas bastante influentes no período - por outro, fica clara a importância de se pensar a produção da época a partir de um solo de disputas em torno dessas e outras noções, no qual o campo de batalha é a arena social. (SILVA, 2014, p.97)

Em algumas experiências de viagens realizadas no país motivadas pelo momento de buscar as tradições que o neocolonial incitava, alguns viajantes desenvolveram esse itinerário de outra forma, aplicando nele outra interpretação do passado, dando prosseguimento à pesquisa iniciada nas viagens acadêmicas e neocoloniais a partir dos conceitos da modernidade, principalmente na arquitetura.

\section{_no Brasil moderno}

O cenário que motivou as viagens modernas é o de uma inquietação intelectual aliada aos lucros advindos da economia do café, e das transformações 
urbanas provocadas pela atividade industrial que crescia, particularmente no estado de São Paulo. Paralelamente o mundo vivia o pós-guerra e assistia o surgimento das vanguardas artísticas, como o Cubismo, Futurismo, Expressionismo, e essas correntes começavam a ser difundidas no Brasil, seja através de artistas que vinham ao país ou da prática de estudantes brasileiros que iam estudar na Europa. É desse cenário que eclode a Semana de Arte Moderna de São Paulo, em 1922 e começam a ascender alguns artistas que se tornarão expoentes dessa corrente artística no país.

Foram transformações de monta, estimulando intelectuais e artistas brasileiros, sobretudo nos modernistas, novas formas de representar a sociedade brasileira, além de gerar uma busca pela identidade nacional, expressa na brasilidade. Figuras proeminentes da nossa intelectualidade e cultura se debruçam, então, sobre uma temática mais nacional. (...). Genericamente, intelectuais e artistas modernistas pretendiam, nesses anos iniciais do movimento, olhar o Brasil a partir de suas características interiores, e não mais pelo viés proveniente do exterior[...] (SANTOS, 2012, p.45)

O conjunto de viagens, adotado como objeto para a investigação das relações e consequências para com o moderno no Brasil corresponde às viagens que se iniciam em 1919, na visita de Mário de Andrade às cidades do barroco mineiro. Essa viagem é aquela que impulsiona a idealização de uma caravana modernista, composta por personagens emblemáticos do cenário artístico nacional, além de uma figura, espécie de padrinho estrangeiro, que é Blaise Cendars, representando tanto a ligação com as vanguardas europeias quanto o anseio por transpô-las.

Caravana esta que começa no Carnaval no Rio de Janeiro e depois chega a Minas Gerais, na Semana Santa do ano de 1924. Nesse mesmo ano, o então jovem estudante de arquitetura, Lúcio Costa, realiza a mesma viagem, mas com objetivos inicialmente distintos, de caráter de documentação patrimonial.

Esse período então ficou caracterizado pelo conjunto de viagens realizadas a partir da formação de um grupo que debate o modernismo artístico no país. Os registros deixados e as experiências provocadas por essas viagens nos agentes desse movimento foram responsáveis por trazer para o debate os conflitos e as ambiguidades de um Brasil pouco explorado, ou inexplorado sob a perspectiva moderna.

A perspectiva moderna era a de promover uma renovação nas artes e na arquitetura no país, no influxo dos movimentos correspondentes em 
outros lugares do mundo, como as vanguardas artísticas. Quando teóricos, artistas do movimento moderno em construção no Brasil visitam o passado colonial, a relação é a de renovar o sentido da tradição ali presente. Tradição essa entendida, e eleita como a arquitetura colonial e a produção do barroco mineiro.

ComoapontaGONÇALVES(2012),osentido eoprogramadaviagem tiveram nesse momento diferentes consequências para a produção arquitetônica, essas novas formas de olhar o passado, a tradição, proporcionaram a evolução de um percurso que fundou uma metodologia de projeto única e verdadeiramente moderna.

Essa apropriação da história foi possível porque a modernidade a liberou da estrita manifestação estilística, abrindo caminho para uma leitura de teor gráfico, formal, estrutural. Dessa maneira, o arquiteto moderno lê a arquitetura do passado a partir de outras chaves de interpretação que não só a classificação temática, estilística, passando a classifica-la em elementos, tipologias, por exemplo. Essa sequência analítica questiona como e porque o edifício foi projetado, e assim, por um processo que é reflexivo, se aprende a projetar, aprendendo o objeto.

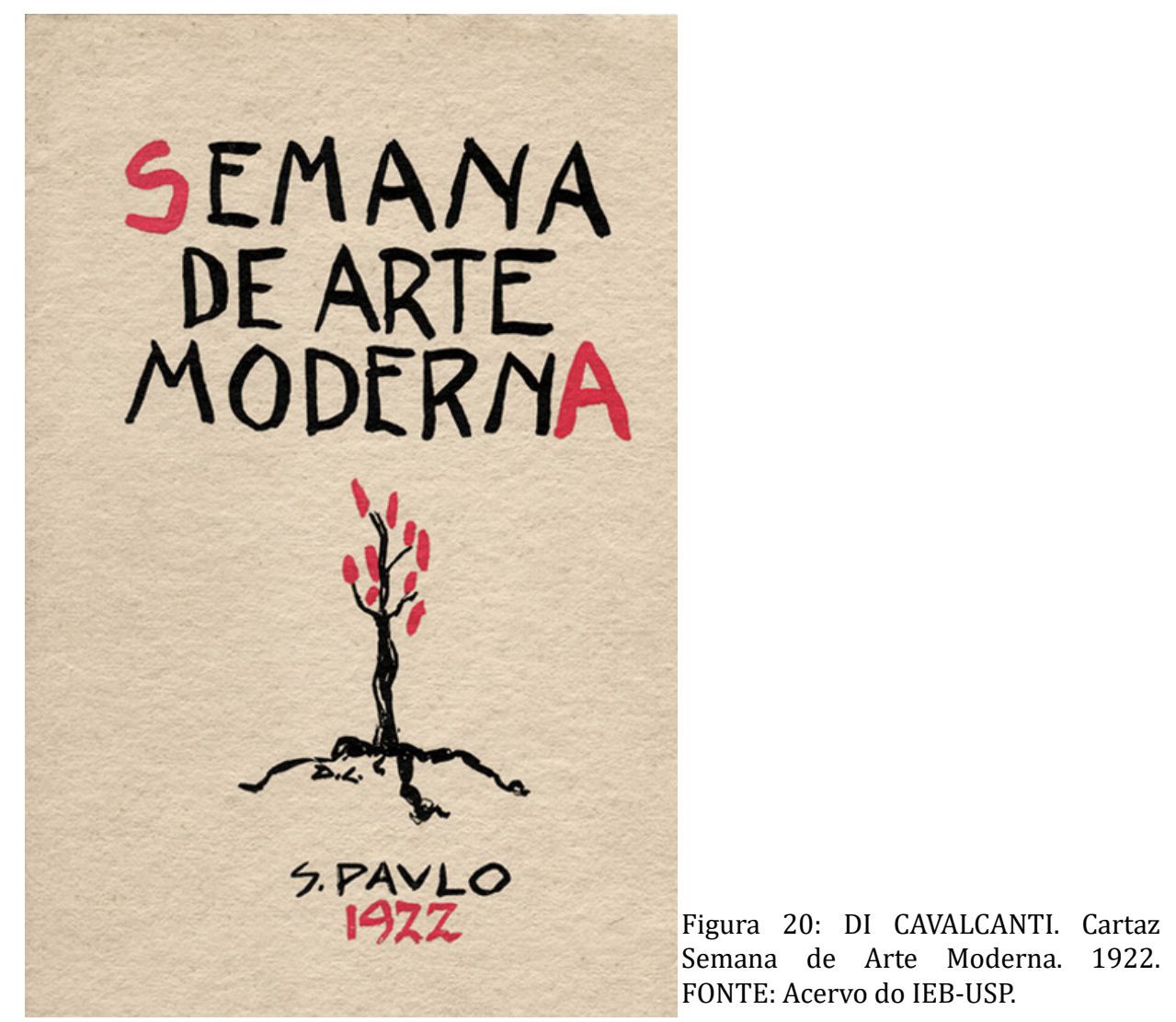


Ao mesmo tempo em que o modernismo brasileiro foi ancorado nas ideias de vanguarda europeias, o objetivo do movimento era o de romper com os padrões culturais e estéticos do século XIX, o de buscar construir o imaginário de um novo país.

Sinteticamente, pode-se dizer que o modernismo, embora reflexo de movimentos que ocorriam no mundo desde fins do século XIX, só se consolida de fato no Brasil com a Semana de Arte Moderna de 22. E que também carrega uma contradição interna pois, oriundo de ideias estrangeiras (atitude tão criticada pelos modernistas), ao mesmo tempo se propõe um olhar para dentro do próprio país. 0 modernismo europeu, sobretudo com suas correntes futuristas, cubistas, dadaístas e outras, já existia na cena cultural e artística daquele continente e serviu de inspiração aqui, apesar das críticas dos modernistas brasileiros aos excessos de estrangeirismos presentes no Brasil. (SANTOS, 2012, p.55)

A maneira como muitos desses agitadores culturais e artistas encontraram de construir esse ideário foi através da investigação, do confronto direto com regiões pouco estudadas do país, pouco exploradas artisticamente no âmbito do moderno, em busca de um passado eleito para formar as bases de uma arte moderna brasileira, num processo de "olhar pra dentro do próprio país".

São Paulo foi o palco a Semana de Arte Moderna em 1922 e a capital onde viviam grande parte de seus promotores, toda a atualização pela qual o movimento passava acontecia de uma forma ou outra por ai, mas foi preciso explorar o Brasil para fora da metrópole. Uma forma de buscar o que viria a ser as bases do modernismo artístico brasileiro foi a aproximação com essas regiões pouco exploradas do país:

A aproximação com realidades diversas daquelas encontradas na cidade de São Paulo, a possibilidade do contato com o outro, o próprio questionamento de suas esferas de pertencimento, enfim, tais deslocamentos apresentam um caráter fortemente etnográfico, restabelecendo novas fronteiras entre as esferas. (SODRÉ, 2010, p.71)

Enquanto viajavam, os pesquisadores buscavam experenciar a cidade que visitavam em toda a sua potencialidade cultural, era de grande importância captar as diversas manifestações populares que as cidades ofereciam, em uma chave etnográfica.

Pouco antes dessa viagem a Minas Gerais (1924), o mesmo grupo modernista passa o Carnaval no Rio de Janeiro, observando festas e manifestações populares brasileiras. Essas visitas tinham como 
motivação o encontro com um primitivismo que deveria pautar a tendência modernista. Para tanto, escolheram datas tradicionais Quaresma e Semana Santa - que, eventualmente, possibilitariam observações acuradas nas cidades históricas mineiras. 0 primitivismo se fez presente no modernismo brasileiro como uma influência das vanguardas europeias e seus muitos artistas e intelectuais próximos dessa conceituação: Gauguin, Pablo Picasso, Paul Klee, Joan Miró, André Breton, Blaise Cendrars, entre outros. (SANTOS, 2012, p.53)

O ano de 1924 se constituiu como um marco para o desenvolvimento da visão modernista no Brasil, para a definição das vozes que vão defender uma nova visão sobre as tradições, sobre o localismo e a universalidade nas artes e na arquitetura. 0 cenário de 1924 é de agitação cultural, de debates acalorados.

Em abril de 1924, ocorre a "viagem de redescoberta do Brasil" pelos modernistas, uma viagem toda peculiar, onde cada personagem do grupo tem uma relação própria de anseio, de inspiração para com a pesquisa que ia ser desenvolvida, para com o projeto estético do país e subjetividades.

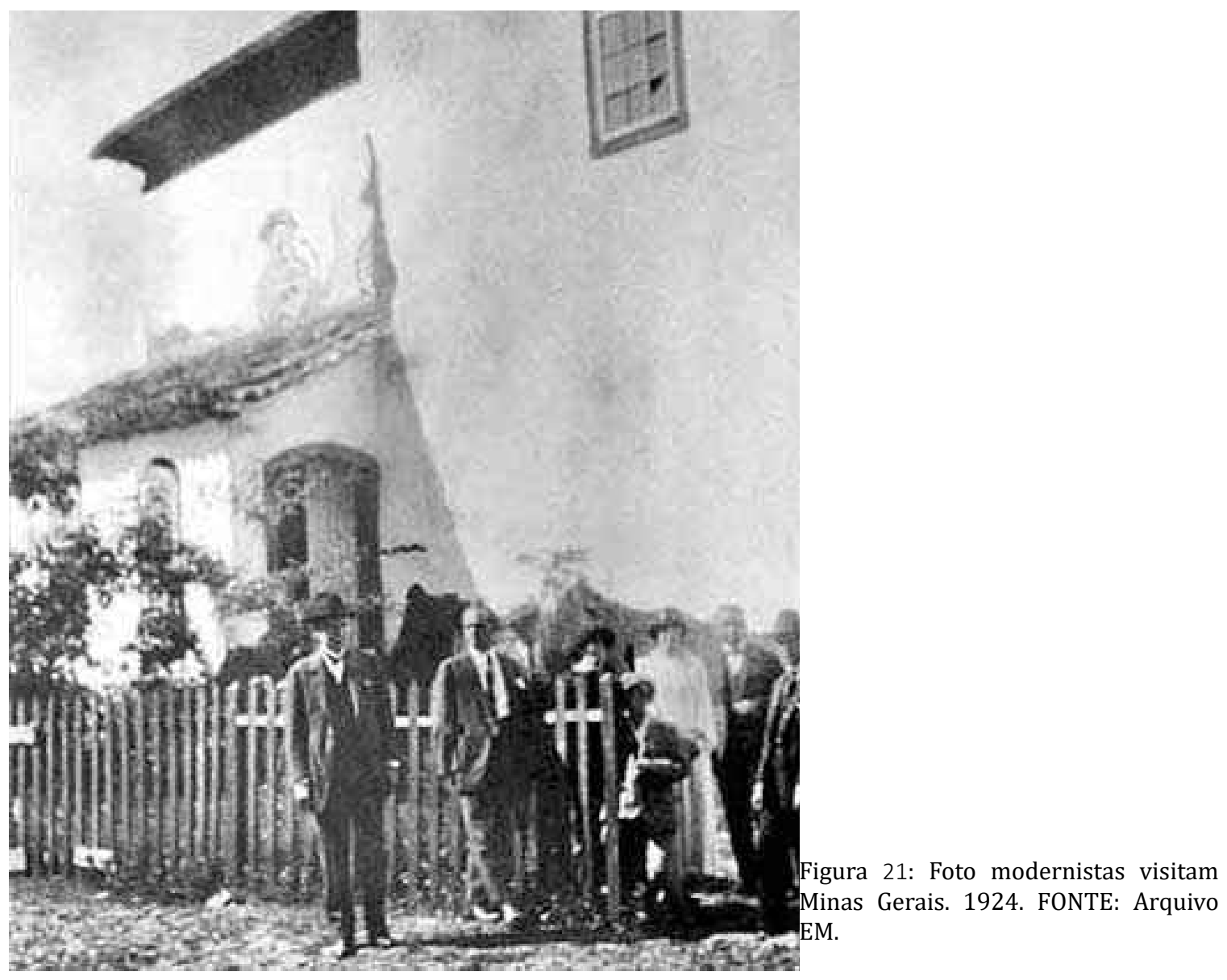


O grupo que compôs a viagem foi: Oswald de Andrade, seu filho Nonê, Tarsila do Amaral, Mário de Andrade, o jornalista René Thiollier, Olívia Guedes Penteado, Goffredo Telles e o poeta franco-suíço Blaise Cendrars.

As cidades que compuseram o itinerário dessa viagem foram as cidades históricas do ciclo do ouro, Mariana, Congonhas, Ouro Preto, São João del Rei, Sabará e também Belo Horizonte. Essas cidades eram recheadas de construções, obras da arquitetura colonial.

Procurava um contato mais próximo com o povo, dentro da perspectiva estética do primitivismo proposta pelas vanguardas europeias. A viagem ocorre entre 16 e 29 de abril de 1924, período que inclui a Semana Santa. E foi suficiente por criar respeito e admiração, do grupo modernista, pelo barroco mineiro e, sobretudo, para as obras de Aleijadinho. (SANTOS, 2012, p.54)

Entre algumas descobertas que a viagem de 1924 às cidades históricas mineiras provocou uma delas chama a atenção e nos fornece pistas para pensar sua motivação, ou que se buscava encontrar naquele passado:

Segundo Jardim de Moraes (1978), a viagem foi importante para a constatação de que, se naquele período não havia artes plásticas, o Brasil já contara com ela, no período colonial, através de Aleijadinho. Aliás, alguns autores apontariam que, no campo artístico, tínhamos uma literatura pungente, mas não artes plásticas. Moraes (1978) escreve: "O conhecimento ou descobrimento das artes plásticas do período colonial, como do Aleijadinho, por exemplo, é resultante do surto de redescoberta do país empreendido pela geração modernista.". (SANTOS, 2012, p.39)

Esse chamado "surto" de descobertas revelou tanto aspectos desconhecidos acerca do passado colonial do país, como interpretou esses signos em sua potencialidade de uma arte futura, não da maneira como o movimento neocolonial vinha fazendo, mas inaugurando um método de pesquisa moderno.

Esse momento no Brasil possibilitou uma reconciliação histórica com o passado, superando a interpretação estilística e buscando elos entre a incipiente produção modernista nas artes e na arquitetura e uma matriz tradicional, popular, nacional que identificaram em um passado.

Com essa viagem, foi aberto um caminho, um diálogo possível entre as noções de tradição e modernidade das quais falamos anteriormente, na experiência do movimento moderno brasileiro, que leu os signos do passado e 
de certa forma se apropriou deles enquanto questão.

A reflexão modernista, vinda deste contacto que se pretendeu direto com uma parcela do povo brasileiro, pôde focalizar os processos de criação popular percebendo-os mais livres e mais condizentes com nossas condições e, em alguns pontos, até mesmo apresentando coincidência com propostas de determinadas vanguardas européias. A "viagem da descoberta do Brasil" provoca um amadurecimento no projeto nacionalista de nossos modernistas, fazendo com que a ênfase, que de início recaía com mais força sobre o dado estético, possa ir, progressivamente, abrangendo e sulcando o projeto ideológico. (LOPEZ, 2002, p.16)

SANTOS (2012) identifica, nos impactos dessa aventura de 1924, para todos os personagens envolvidos "momentos de inspiração e de discussão estética". A "viagem de redescoberta do Brasil" acontece em um momento em que o movimento moderno artístico também estava em formação no país, dessa maneira, as viagens tanto ajudaram a firmar conceitos e práticas que passariam a ser próprias do movimento, no caráter nacional que ele assume no Brasil, como alguns conceitos primordiais da interpretação modernista que os integrantes haviam aprendido com as vanguardas influenciaram o formato da viagem.

A viagem se insere então num estágio de amadurecimento do projeto moderno, onde prática de pesquisa, experimentação artística aconteciam simultaneamente à sedimentação dos conceitos do movimento.

Aos poucos, as bagagens trazidas das viagens iam formando um quadro de referências para o desenvolvimento do imaginário artístico moderno e nacional a partir de um redirecionamento do olhar, como explica Lira:

Mas foi talvez por sintetizar um choque nas relações entre ofertas europeias e fontes nacionais que a viagem de 1924 às cidades históricas de Minas tornou-se tão importante no imaginário do modernismo, como emblema de uma guinada dialética fundamental - porque travejada pelo influxo das vanguardas internacionais - no enfoque do tradicional e do popular pelo movimento.(...).Esse redirecionamento do olhar para as coisas populares parecia acrescentar novos ingredientes às querelas artísticas do período, começando a funcionar como um dos polos fundamentais de desnivelamento/ nivelamento estético-cultural entre as convenções. Para tal, a viagem pelo Brasil cumpriu papel fundamental. Não somente porque alterava os itinerários de formação transoceânicos consagrados junto à intelectualidade 
brasileira, mas porque embaralhava as noções do que era o interno e o externo, o tradicional e o contemporâneo, o exótico e o nativo, e não menos as relações entre origem e destino, sujeito e objeto da viagem ao fazer desviar o estatuto do viajante de suas figurações civilizatórias habituais: o naturalista, o folclorista, o etnólogo, o aventureiro e mesmo o turista. (LIRA, 2015, p.367)

Nesse momento, viajar foi fundante para sugerir os rumos do movimento moderno no Brasil:

O divórcio da realidade brasileira, em que a maior parte dos nossos escritores sempre viveu, fazia com que a paisagem da Minas barroca surgisse aos olhos dos modernistas como qualquer coisa de novo e original, dentro, portanto, do quadro de novidade e originalidade que eles procuravam. E não falaram, desde a primeira hora, numa volta às raízes da nacionalidade, na procura do filão que conduzisse a uma arte genuinamente brasileira? Pois lá nas ruínas mineiras haviam de encontrar, certamente, as sugestões dessa arte. (BROCA, 1997, p.58)

Só se compreende a especificidade da iniciação à qual corresponde o ano de 1924 se associarmos a essa as trajetórias de seus personagens viajantes. Escolhemos para esse estudo quatro deles, emblemáticos, por ser cada um representativo de um campo disciplinar e artístico, um estudante de arquitetura, um homem da literatura, uma pintora e um poeta estrangeiro. Desse quadro, é importante ressaltar que o primeiro deles, faz a viagem a Minas Gerais no ano de 1924, mas para a cidade de Diamantina, não na mesma viagem da caravana modernista da qual participam os outros três.

\section{_o caráter de iniciação da viagem a Minas Gerais}

Os personagens dessa viagem são Blaise Cendrars, Mario de Andrade, Tarsila do Amaral e Lucio Costa. Cada um deles pode ser apresentado por um conjunto de palavras, funções que desempenharam, oficialmente e também intimamente, quando à vontade no grupo de amigos, principalmente os três primeiros personagens: Blaise, Mário de Tarsila, por compartilharem essa viagem juntos.

O nosso primeiro personagem, Blaise Cendrars, poeta e agitador, poeta das palavras lidas com uma forte presença gráfica, do modernismo parisiense à nova pátria que assumira nos trópicos, daqui em diante b.c.

Mário de Andrade, segundo personagem, o homem plural, escritor, 
cronista, poeta, crítico, estudioso da música, da cultura, o narrador. Mário teve um papel importante na articulação do grupo, aglutinador, m.a.

Tarsila do Amaral, personagem terceira, desenhista, pintora das brasilidades, inventora, viajante. Tarsila foi das personagens, a que mais leu Minas em seus elementos de composição, t.a.

Lucio Costa, estudante, arquiteto, entre a arte e arquitetura tradicional colonial e barroca e o moderno, um moderno brasileiro, e português, lc.

A coleta dos muitos eventos das trajetórias de viagens, subjetivas e profissionais desses quatro personagens apresentados, deu origem a um quadro da biografia de cada um deles, com a marcação dos dados relativos ao período de formação, de atuação profissional e da produção intelectual e artística em escala temporal.

Nesse quadro, percebemos um núcleo denso de informações concentrado nos anos 1920, esse polvilhado de imagens se referem aos registros deixados por esses personagens viajantes, como índices de uma história.

Cada registro indicado no quadro trás consigo uma possibilidade de leitura, mas para essa leitura, foi necessário compreender o contexto de 1920.

A justaposição dos registros nos obriga a olhar para o conjunto, em um primeiro momento, a fim de perceber sua unidade, que é temporal, mas que também é fundada com base em um questionamento comum, que é o da pesquisa do Brasil através do resgate da cultura do período barroco.

Para esses viajantes, Minas tinha algo de novo, mas também de necessário, na construção do sentido de modernidade, seja na arte, na literatura, na arquitetura. A importância dessa viagem se deu no caráter de iniciação que ela teve na trajetória desses viajantes. Para Sodré (2010), além de marcar o início de uma série de pesquisas futuras:

Esta viagem representou uma guinada importante para o modernismo brasileiro no enfoque nacionalista anterior, porque travejada pelo influxo das vanguardas contemporâneas. Nela, um novo olhar para a arquitetura colonial se afirmava, não mais tributário da matriz lusitana erudita como em Ricardo Severo, nem de sua suposta herança mourisca ou adaptação ao meio climático e contribuição brasílica, como para José Mariano e os adeptos do neocolonial. Doravante o legado artístico colonial passava a ser visto não como um estilo acabado, mas como produção híbrida, ou antes, popular, e a arquitetura barroca reinterpretada como universo aberto à intervenção de cristãos e pagãos, artistas e artesãos, europeus, ameríndios e africanos. (SODRÉ, 2010, p.71) 
Essa guinada aconteceu principalmente no sentido de alterar, inserir novos conceitos e práticas de preservação e patrimônio, que se deu também porque alguns dos personagens em questão atuavam em órgãos do governo, como o Departamento de Cultura de São Paulo, o SPHAN, de 1937.

A substância da viagem foi o barroco mineiro, das construções, da arte religiosa, e com um apelo significativo para obra de Aleijadinho, que era a representação do popular, do autêntico. A figura do Aleijadinho despertou esse interesse por ser a manifestação da autonomia e da singularidade da arte brasileira em meio à cultura colonial, pela interpretação dos modernistas.

A interpretação dessa noção de autonomia e singularidade como a essência da arte brasileira, como uma origem com a qual o movimento moderno deria dialogar, se fez por meio de correlações e ambiguidades, às vezes dentro da obra de um mesmo intérprete quando colocados em confronto.

O espaço e o tempo foram os mesmos para os quatro personagens, mas as referências, enquanto bagagem que cada um trazia individualmente e aspectos de suas formações, que tiveram influência na forma em que a viagem os afetou.

Nesse sentido, a viagem não teve um fim se si, mas evidenciou, em cada um, a necessidade de continuar a busca, externamente, em viagens seguintes, ou internamente, no embate com a produção de cada um. Caracterizando-se como o despertar que incitou a continuidade da pesquisa.

0 barroco no Brasil se desenvolveu de uma forma que podemos caracterizar como intensamente "brasileiro", no sentido regional. 0 estilo chega ao Brasil no século XVIII, cerca de 100 anos depois da Europa, e recebe influências portuguesas, francesas, italianas, espanholas e dos próprios filhos de portugueses nascidos no Brasil, com tudo isso, o barroco se desenvolveu de forma peculiar por aqui, na expressão da religiosidade popular, na contenção, na elegância, no emprego de materiais locais na decoração, como a pedra sabão. É nesse sentido que podemos dizer que o barroco mineiro se afirmou por um processo de aclimatação, aclimatação aqui não somente em seu significado físico, do clima, mas no entendimento de acomodação cultural, de ter sido permeado pelas influências e pela habilidade popular de seus artesões.

0 movimento modernista compartilhava de afinidades e motivações estéticas com vanguardas européias tais como o cubismo e o futurismo. No entanto, antenados e estudando o que se passava na Europa em termos de inovações estéticas, os modernistas se utilizavam dessas noções vanguardistas para criar seu próprio vernáculo. Assim, a partir do diálogo com as novas linguagens estéticas que surgiam no além mar, os modernistas 
propuseram a recriação e revalorização de uma estética nacional e de uma tradição artística própria. A "vanguarda modernista brasileira" primaria, então, por uma busca no passado de motivos que seriam reinventados no presente, que tomariam as formas da inovação, por assim dizer, e não pautava-se em uma ruptura radical com esse mesmo legado pretérito. As novas linguagens e soluções advindas com o cubismo, por exemplo, serviam aos modernistas brasileiros como um meio de se reinventar uma tradição artística nacional. (NATAL, 2007, p.205)

A partir da experiência e da prática da viagem dos modernistas no Brasil, tiveram muitas outras viagens e mais outros viajantes, que percorreram o país em busca de territórios desconhecidos, a fim de confrontar o espaço, a cultura em questionamentos individuais e coletivos.

0 conceito que se tem previamente ao planejar a viagem é embaralhado no decorrer da viagem, é posto em confronto. E é desse embaralhamento que se tira o aprendizado do que era imprevisível no roteiro, dá à viagem uma dimensão reflexiva mais forte do que a da certeza do que se quer encontrar quando se parte.

É interessante notar como esses diferentes personagens-viajantes, recortados propositalmente de áreas de atuação diversas percorreram o Brasil com as mesmas indagações. De certa forma, se faz sempre a mesma viagem, como as jornadas posteriores a 1924 empreendidas por esses viajantes, que foram feitas a partir da leitura e da reelaboração constante dos registros, seja em projetos de arquitetura, projetos junto à esfera pública, edições de livros, pinturas, entre outros. 0 percurso, daí em diante, é reflexivo, inventivo. 
107

Figura 22: VILLA, 2018. Diagrama de organização dos desenhos na prancha. FONTE: Acervo da autora. 


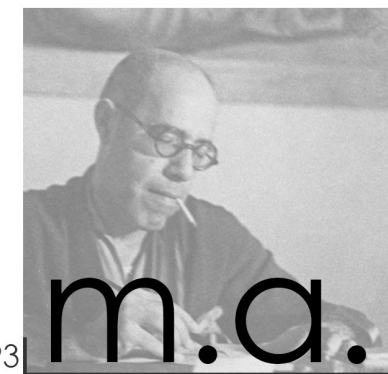

1909|1910|
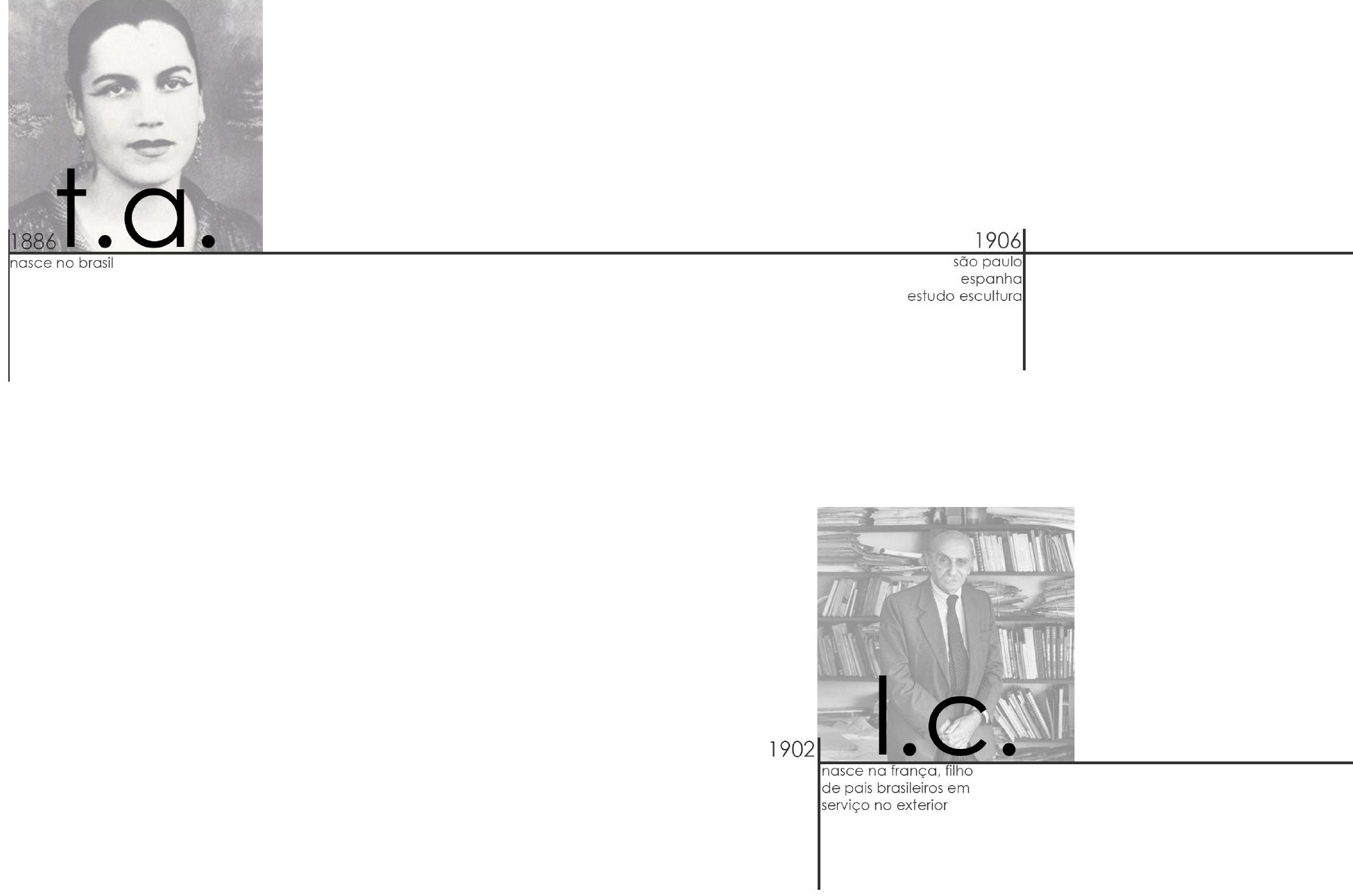


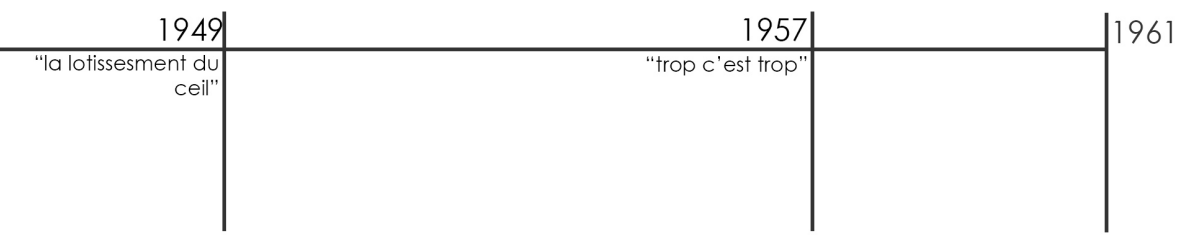

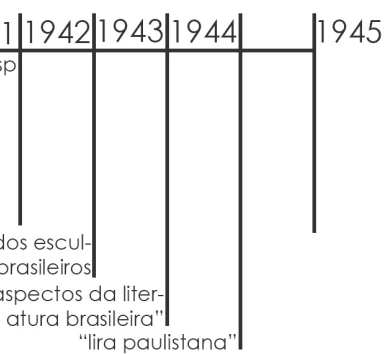

1948 1951|1952

viagem a portuga

"introdução a um
relatório"

projeta parque

guinle, no rio de ja-

neiro "muita construção,
alguma arquitetura e

um milagre"
un

um milag

tugal

1957

19601961

concurso de brasília

inauguração de

brasilia
braco de 
CAPÍTULO TRÊS_DAS LEITURAS DOS REGISTROS 


A questão desse capítulo foi identificar nos registros, ou nos conjuntos de registros apresentados no quadro em linha do tempo, aqueles que possam ser lidos e analisados através de sua forma de elaboração.

Os formatos dos registros coletados pra essa pesquisa foram divididos entre: relatos textuais e relatos visuais. Os relatos textuais aparecem em formato de prosa e poesia, dentro de um campo maior que é a da literatura de viagem. Como relatos visuais entendemos ou circunscrevemos nesse trabalho os croquis realizados durante as viagens, os desenhos de rascunho, de levantamento, que em alguns casos, serviram posteriormente para a elaboração de obras pintadas ou mesmo de arquitetura.

Essas viagens brasileiras que analisamos, podem ser pensadas como geradoras de uma coleção de relatos, e o essencial desses relatos, do momento de sua produção, desse tempo "en route" é a potência que neles existe. Potência na observação mais rápida, instantânea e urgente preservada em um traço ou uma anotação. A ideia em potencial é mais evidente no momento dos relatos, principalmente na forma de rascunho, é a ideia bruta, que vai sendo trabalhada e de certa forma sendo contaminada por outras exigências, adequação aos formatos mais rígidos da produção final. Nesse sentido, consideramos esses croquis e anotações como produções que merecem atenção, podem revelar o essencial de uma ideia e também expandir para outras observações e comentários.

Entendemos o desenho ou a escrita rápida como um recurso presente no próprio processo de pensamento, de elaboração e aceitação de uma ideia. Nos relatos de viagem fica mais fácil identificar esse pensamento, por estar temporalmente mais próximo da primeira impressão em relação a um lugar, uma obra, uma cidade, ou até mesmo um país.

Dessa forma inferimos que, pode nos registros existir uma potência mais latente do que na obra final resultante desse processo de observação, de aprendizado que uma viagem proporciona, porque a obra mais madura dialoga também com outros mecanismos, os da sua fatura, meio, que dissolvem em parte a urgência presente no rápido registro, e a espontaneidade da primeira impressão. Sem duvida a obra realizada com base nos desenhos preliminares é repleta de características outras, também importantes, mas que lhes conferem outros valores estéticos.

Aqui, a análise se dá na busca por identificar nos registros rápidos, simplificados, superficiais que se faz na viagem, o pensamento em potencial, os elementos com os quais os aqui chamados personagens-viajantes compuseram 
tanto suas obras como suas trajetórias profissionais e intelectuais.

No caso da análise textual, a tentativa se dá na identificação dos termos de uso recorrente pelos autores, nas obras selecionadas a partir de uma coleção de registros disponíveis na linha do tempo dos personagens, apresentada no capítulo dois.

Para os relatos visuais, em um primeiro momento, buscaremos entender o que a justaposição das imagens desses "relatos visuais" nos fornece em uma aproximação geral, novamente como estão dispostas na linha do tempo, mas também em outro tipo de aproximação, permitindo ler graficamente esses índices para além de uma escala somente temporal. Será pertinente ainda a definição de critérios para ler cada imagem e relacioná-la com outras, formando conjuntos de técnicas que as aproximam.

Os critérios levaram em conta o tipo de desenho, mais realista ou abstrato, compositivo, por exemplo, traços rápidos e traços precisos; o tempo de elaboração e o ritmo de viagem impresso na fatura do registro.

Essas informações puderam ser extraídas da quantidade de detalhes que a imagem captou, e essa característica técnica nos revelou características importantes de como foram essas viagens e quais as preocupações dos viajantes acerca dos impulsos visuais aos quais foram submetidos.

\section{_relatos textuais}

Dentro desse tipo de registro, encontramos dois de nossos personagensviajantes, Blaise Cendrars e Mario de Andrade.

Blaise Cendrars produziu, ao longo de sua estadia no Brasil, que consistiu em três viagens, desde 1924, um diário de viagem em poesia, intitulado "Feuilles de Route", que pode ser traduzido do francês como: roteiro de viagem. Obra que foi produzida em várias versões de edições, e que descreve fragmentos dessas três viagens, desde a partida do poeta da França, contendo o tempo de estadia e percurso pelo Brasil até o seu retorno. Em prosa, Cendrars deixa a obra "Prose du Transsibérien".

Mário de Andrade, por sua vez, brasileiro, realizou em 1919, uma primeira viagem a Minas Gerais, isolado do restante do grupo, e escreveu crônicas, posteriormente publicadas em "Arte religiosa no Brasil". Depois dessa primeira impressão, e motivado por ela, Mário participou da incursão ao interior de Minas Gerais com o grupo modernista em 1924, viagem que amplia as questões abordadas na primeira viagem. 
_b.c.

Blaise Cendrars foi um personagem importante para a realização da caravana modernista nos moldes em que esta ocorreu em 1924. 0 poeta, que fez nesse mesmo ano a primeira de sete visitas ao Brasil, foi uma espécie de mentor intelectual do grupo, por representar a visão estrangeira e estar em contato direto com as influências europeias. Blaise vem ao Brasil subvencionado pelo mecenas Paulo Prado ${ }^{16}$, e aqui permanece por nove meses, participando não só da viagem a Minas, mas de outros eventos e conferências.

Uma das motivações da viagem por parte dos brasileiros do grupo era apresentar o Brasil ao francês, que via no país uma possibilidade criativa que já não pensava ser possível no velho mundo. 0 desejo de conhecer o Brasil vem dos confrontos intelectuais do artista consigo mesmo, que ele começou a travar no seu fazer como poeta moderno, europeu, em que se via um tanto quanto desiludido com os rumos da arte na Europa, das vanguardas artísticas, da ausência de identificação. Diante desse cenário, o desejo por viajar por uma terra nova o fascinava.

0 relacionamento com o grupo modernista paulista reforça a ligação de filiação e referência que, na época, a intelectualidade brasileira conservava com a tradição europeia, relação que era também de compartilhamento, encantamento, de ambos os lados.

Novamente, a presença do olhar estrangeiro a Minas Gerais ajudou a despertar nos outros companheiros o interesse pelo que ele considerava autêntico e popular na arte barroca mineira.

Para alguns autores estudados, como vimos, essa busca pela brasilidade, talvez uma das características mais marcantes do modernismo brasileiro, foi acentuada a partir de 1924, provavelmente por influência do contato com Blaise Cendrars e pela "viagem da descoberta do Brasil”. (SANTOS, 2012, p.55)

16 Paulo Prado, escritor e um dos principais mecenas e incentivador do movimento modernista no Brasil. 


\section{- da estrutura de feuilles de route}

A obra de Blaise Cendrars Feuilles de Route, é escrita em 130 poemas, que contam a impressão do poeta viajante sobre o tempo que este viajou por terras brasileiras, sendo dividido em três partes: I. Formose, essa parte contém 73 poemas de impressão sobre o percurso desde a França, a bordo do navio Formose, de Le Havre à São Paulo; II. São Paulo, parte que contém 6 poemas sobre a cidade brasileira; III., parte não intitulada, que contém 51 poemas de temas diversos, narrando a experiência brasileira do poeta.

Feuilles de Route não compõe exatamente um caderno de poemas sobre o Brasil, em sentido estrito. É antes um caderno sobre a viagem de Cendrars ao Brasil. Não há nestes poemas, por exemplo, considerações mais detidas sobre os brasileiros e seus modos de vida, sobre política, história e cultura brasileiras - questões que são desenvolvidas pelo autor em ensaios e reportagens - e as descrições das paisagens e principalmente da natureza, tema que é largamente desenvolvido, parecem ter maior relevância. As cidades brasileiras, por sua vez, são vistas a partir de uma perspectiva distante, ou a partir da perspectiva de um eu-lírico que se encontra em um barco, en route[...] (ALEM, 2011, p.93)

Podemos considerar a obra um relato de viagem, por vários tópicos usados em sua estrutura de construção. A mais marcante característica é a correspondência entre o percurso físico da viagem e a organização dos poemas no livro, com uma ordem cronológica dos eventos. Sobre esse ponto, vale ressaltar que existiram dois formatos de escrita no livro: A primeira corresponde ao que vamos denominar de relato "in loco", que são os poemas escritos no instante da viagem, simultâneos a ela; o segundo formato, por sua vez, "poemas de memória", são aqueles que foram elaborados em um momento posterior à viagem.

As diferenças essenciais entre esses dois formatos são, a impressão do ritmo da viagem nos poemas "in loco", o caráter de anotação, instantâneo, em relação aos poemas do segundo tipo, que foram escritos relacionandose a viagem, mas, em alusão às experiências vividas, utilizando o recurso da lembrança, muitas vezes impreciso.

É perceptível na unidade da obra uma trajetória linear. Mesmo que, nem todos os poemas tenham sido feitos instantaneamente no momento da viagem e em sequência. A sequência e a ordem da colocação que os poemas obedecem 
na publicação, essas se referem ao percurso real vivido pelo personagemviajante, onde o caderno que acompanhou o viajante é que determina o roteiro.

O caderno, em seu conjunto de anotações, revela uma aparente analogia entre o ritmo da viagem, entre o tempo condicionado pelo transporte e permanência em cada localidade e o ritmo, e o tom da escrita.

Essa relação se estabelece na medida em que lemos os poemas escritos quando Cendrars estava à bordo do navio, por exemplo, nesse ponto de vista, as paisagens descritas nos poemas são longínquas, indefinidas, e muitas vezes são usados como referência de localização as constelações, guiando a orientação que se tem observando o ceú.

“35 57' Latitude Nord 15o 16' longitude ouest":

(...)

Mais tout monte d'un degrée de tonalité

Le soir j'en avais la preuve par quatre

Le ciel était maintenant pur

Le soleil couchant como une roue

La pleine lune comme une autre roue

Et les étoiles plus grandes plus grandes (CENDRARS, 1990) ${ }^{17}$

O poema "Iles" fala dessa indefinição das formas que o poeta vê nos morros e imagina:

\section{Iles \\ Iles}

Iles ou l'on ne prendra jamais terre

Iles où l'on ne descendra jamais

Iles couvertes de végétations

Iles tapies comme des jaguars

Iles muettes

Iles immobiles

Iles inoubliables et sans nom

Je lance mes chaussures par-dessus bord car je voudrais bien aller jusqu'à vous (CENDRARS, 1990) ${ }^{18}$

\footnotetext{
17 Poema escrito em 1924. (...) Mas tudo tem um grau a mais de tonalidade / À noite tirei a prova dos quatro / O céu estava agora limpo / O sol poente como uma roda / A lua cheia como uma outra roda / E as estrelas maiores maiores (...)// Tradução: Teresa Thiérot. 18 Poema escrito em 1924. "(Ilhas): Ilhas/Ilhas/Ilhas onde nunca pisaremos em terra/ Ilhas onde nunca desceremos/Ilhas cobertas de vegetação/Ilhas acachapadas como onças/ Ilhas mudas/Ilhas imóveis/Ilhas inesquecíveis e sem nome/Jogo meus sapatos por cima do bordo porque gostaria muito de ir até vocês." Tradução: Teresa Thiérot.
} 


\section{_o percurso}

No poema "Debout", o primeiro da parte "II. São Paulo", o escritor descreve um observador, um personagem da cidade, que é afetado pelos estímulos visuais e sonoros que a cidade provoca no sujeito, e a tentativa de absorver esse novo mundo é a mesma que Cendrars faz em seus relatos de viagem.

Os poemas são construídos a partir da perspectiva do escritor na viagem, dos meios e modos de viajar. Como os meios de locomoção mudam ao longo da viagem, os pontos de vista a partir dos quais se escreve também.

"São Paulo" é o poema que finaliza o índice de "I. Formose", escrito em fevereiro de 1924, o qual marca a chegada ao Brasil, no momento em que o viajante chega ao topo da serra e visualiza a capital paulista:

Enfin voici des usines une banlieue un gentil petit

Tramway

Des conduites électriques

Une rue populeuse avec des gens qui vont faire leurs

emplettes du soir

Un gazomètre

Enfin on entre en gare

Saint-Paul

Je crois être en gsre de Nice

Ou débarquer à Charring-Cross à Londres

Je trouve tous mes amis

Bonjour

C'est moi. ${ }^{19}$

Nos poemas, Cendrars costuma empregar um recurso linguístico, a metalinguagem, ou "meta poesia", em que Cendrars se apresenta como personagem de sua própria observação do que descreve, ele se vê tão integrado à paisagem, como se fizesse parte dela, e se insere na cena.

Blaise se retrata em seus poemas, em dois momentos principais, nesse último poema de I.Forsmose, quando se apresenta à cidade e aos que viriam a ser seus companheiros de viagem no Brasil, e num segundo momento, num

19 Poema escrito em 1924. Enfim eis usinas um subúrbio um gentil bondinho / Fios elétricos/Um rua populosa com gente que vai fazer as suas compras da tarde/Um gasômetro/Enfim se chega na estação/São Paulo/Penso estar na estação de Nice/Ou desembarcar em Charring-Cross em Londres/Encontro todos meus amigos/Bom dia/Sou eu. Tradução Patrícia Galvão. 
tom de identificação, de pertencimento, no último poema agora da parte II. São Paulo, quando se despede da cidade, a qual depois ele retorna, intitulado "Départ".

\section{_ a escrita}

Na leitura de alguns desses poemas, podemos identificar os recursos poéticos utilizados nessa espécie de diário de viagem, esse é um exemplo de relato textual que usou a escrita para se aproximar da criação da impressão de imagens fotográficas no leitor.

0 autor faz uso, ao longo desse caderno, de uma escrita rápida, urgente por captar o essencial das paisagens brasileiras com as quais ele tem seu primeiro encontro em 1924.

Em termos de recursos linguísticos, Cendrars usa o presente do indicativo, a supressão de pontuação, sequências de frases para imprimir no texto sua ideia sobre estar em viagem, "em route".

Outras características da escrita é o tom de reportagem lírica que foi empregado pelo poeta ao descrever cenas cotidianas e da paisagem:

Um repórter de si mesmo, poderíamos dizer. Um sujeito em trânsito, que de suas viagens e novas experiências retira inspiração para a escrita. É um "aventureiro isolado", no sentido literal do viajante, e no sentido original de quem se empenha em se expressar de maneira única, pessoal. Dessa forma, desenvolve uma poética que tenta conciliar reportagem e poesia. (ALEM, 2011, p.26)

Quanto a métrica, os poemas não usam uma metrificação regular, o sentido da leitura se dá pela semântica e por recursos linguísticos que não a sequência padronizada dos versos.

A escrita, a fatura da poesia aproxima texto e fotografia, pela intenção, nos versos, de se criar descrições rápidas, nas quais o leitor forma uma imagem instantânea. Em termos linguísticos, essa relação é possível pelo uso do presente do indicativo, pela técnica da enumeração, versos em que o adjetivo vem de forma gradual, na repetição do substantivo em vários versos, compondo os poemas a partir de frases nominais.

Outro recurso usado nos poemas, além das frases curtas e objetivas em sua descrição, é o recurso da justaposição, efeito de dispor lado a lado criando um acúmulo de informações, que é relacionado ao que se faz no cinema, 
gerando a percepção de "flashs" descritivos.

Nessa publicação que estamos explorando, o autor retoma um procedimento já utilizado em outro trabalho seu, "kodak":

Esta técnica já havia sido empregada no livro de poemas Kodak (Documentaires), concebido, segundo datação do autor, "en voyage" entre 1887 (sua data de nascimento) e 1923 e publicado em 1924. (ALEM, 2011, p.27)

Em termos de unidade formal da obra, é o recurso de diálogo com a técnica fotográfica a torna passível de se ler em unidade. 0 tom do recorte, que se faz em fotografia, é presente nos poemas, como se selecionasse os limites da cena que se deseja descrever, criar a imagem.

Nas palavras de Cendrars (1991):

"Au lieu des photos (...), je tirais des images verbales instantanées grâce au don que j'ai d'exprimer et de ne pas tout dire à volonté, cartes postales mentales que j'adressais à mon tour à mes amis, les poètes de Paris." 20

A técnica utilizada pelo poeta ficou denominada como poesias "cartãopostal", pela qual Blaise poderia enviar impressões da viagem para seus amigos europeus, sem, no entanto relevar tudo, apenas deixa-los com vontade de percorrer essas terras.

Ou melhor, "lettres-océan", como ele define estes "cartões postais mentais". Os poemas de Feuilles de Route seriam, em última medida, nada mais do que cartões-postais utilizados como mensagens práticas para a comunicação entre Cendrars e estes amigos de Paris. (ALEM, 2011, p.28)

La lettre-océan n'est pas un nouveau genre poétique

C'est um message pratique à tarif régressif et bien meilleur marché qu'un radio

(...)

La lettre-océan n'a pas été inventée pour faire de la poesie

Mais quand on voyage quand on commerce quand on est à bord quand on envoie

des lettres-océan

20 "Em vez de fotos [...], eu tirava imagens verbais instantâneas graças ao dom que tenho de sintetizar e de não dizer tudo, cartões-postais mentais que enviava de minha parte para meus amigos de Paris."

CENDRARS, Blaise. " Publicité = poesie », in Aujourd'hui, 9a Parte. Oeuvres Complètes, Paris, Denoël,1991. p. 22. (tradução nossa) 
On fait de la poésie ${ }^{21}$

A técnica poética da associação de imagens se faz pertinente porque não há tempo para se produzir uma representação detalhada, sendo que seria necessário um tempo mais delongado. Assim, o ritmo da viagem fica impresso no ritmo da escrita, no registro textual.

Assim, Cendrars, como um repórter fotográfico, fixa suas impressões de viagem em pequenos poemas documentários, se atendo ao que julga ser digno de retratar no percurso. (ALEM, 2011, p.29)

Diferentemente da primeira parte da obra, os poemas da segunda e terceira e parte foram escritos a partir da memória do poeta viajante.

[...]Nesse caso a memória serviu para a construção dos poemas, mas não atuou enquanto concepção poética, porque os poemas foram escritos para apresentarem claramente a característica de impressões de viagem instantaneamente anotadas, e não de interpretações elaboradas segundo os critérios da memória. (ALEM, 2011, p.57)

\section{_versões e edições}

A obra em questão foi publicada em edições e momentos variados. A primeira edição corresponde à publicação de dezembro de 1924, ou seja, meses depois da primeira viagem de Cendrars ao Brasil, pela editora "Au Sans Paeril", e nessa primeira edição só conatava a parte "I. Forsmose". É também essa primeira publicação que foi ilustrada por Tarlisa do Amaral, com a presença de oito desenhos feitos especialmente para a edição.

A primeira edição da obra, [...] além de contar também com os desenhos originais feitos por Tarsila do Amaral especialmente para ilustração dos poemas, mas que não foram mantidos nas edições posteriores. (ALEM, 2011, p.21)

Atentar para o que há de específico em cada edição também aponta pra outros personagens que estavam envolvidos em sua elaboração, desde a viagem até colaborações pra edição do caderno, como é o caso dos desenhos de Tarsila.

21 Poema escrito em 1924. A carta-oceano não é um novo gênero poético / É uma mensagem prática de tarifa regressiva e bem mais barata do que um rádio/ (...) A cartaoceano não foi inventada para fazer poesia / Mas quando se viaja quando se negocia quando se está à bordo quando se mandam cartas-oceano/ Faz-se poesia // Tradução: Sérgio Wax. 
Algumas peculiaridades sobre a edição e seus momentos distintos, nos revelam informações importantes acerca do posicionamento do autor no período da edição, o que considerou relevante, ou qual parte foi escrita ou revista em um momento posterior. "Feuilles de Route" foi um projeto revisto muitas vezes, partes foram adicionadas, ilustrações foram retiradas.

Além dessas modificações, identifica-se no fazer literário de Blaise Cendrars, uma mudança de foco na escrita, com o interesse de se voltar à projetos em prosa, como romances interminados.

Assim, ele não consegue concluir o projeto inicial de Feuilles de Route, e nunca chegará a fazê-lo por completo. Isto porque, mesmo depois de seu retorno à França dessa primeira viagem ao Brasil, imediatamente se depara com a necessidade de terminar L'Or (seu primeiro romance publicado) e posteriormente abandona a feitura poética para se dedicar quase exclusivamente à escrita de textos em prosa. Segundo o próprio autor, a experiência em solo brasileiro o havia ensinado o ofício de prosador, ou melhor, romancista e, a partir de então, as experiências vividas no Brasil não deixariam de aparecer em suas obras romanescas, memorialísticas ou reportagens. Desta forma, apenas as duas partes: I. Formose e II. São Paulo serão desenvolvidas de acordo com o primeiro esquema. (ALEM, 2011, p.23)

0 que ficou de importante desse processo de projeto, escrita em viagem, escrita de memória e reedições, é o que a experiência brasileira provocou na sua forma e interesse em fazer literatura, usar o meio para fazer uma investigação íntima e da própria linguagem.

\section{_o tema do Brasil | ideia de viagem}

Já se sabe da relação que o poeta-viajante Blaise Cendrars construiu com o Brasil, mesmo antes de sua chegada no país, pelos textos evocativos, pela ideia que desenvolve do país e de modernidade, explorada constantemente em suas produções posteriores ao tempo da viagem, em poemas, prosas, diálogos, projeto de filme.

A escolha do país como segunda pátria por Cendrars certamente também se relaciona com a freqüência e duração das viagens ao Brasil. Eulálio estabelece, com certa exatidão, as datas e as condições das três viagens da seguinte maneira: a primeira se estendeu de 5 de fevereiro (chegada ao Rio; 6 de fevereiro chegada a Santos e São Paulo) a 19 de agosto de 1924, sendo que 
o percurso de vinda foi feito a bordo do navio Formose152 e o de volta a bordo do Gelria; a segunda viagem de 25 de janeiro a julho de 1926; e a terceira viagem de 5 de setembro de 1927 a 28 de janeiro de 1928. (ALEM, 2011, p.69)

Parte da intensidade dessa aproximação com o Brasil se deve aos diálogos que Blaise estabeleceu com os intelectuais brasileiros modernistas.

Os registros que Cendrars coletou de sua viagem ao Brasil foram usados como matéria, insumo de muitas de suas obras, experimentações artísiticas.

[...] a matéria brasileira foi largamente aproveitada pelo autor até o fim de sua vida, muito mais através de textos ficcionais e reportagens, em que os fatos reais são tratados, por um lado, de maneira fantasiosa, ao retomar as memórias e as ficcionalizar de maneira particular. (ALEM, 2011, p.24)

0 personagem viajante que criou em seus textos uma imagem lírica e fantástica do Brasil, transformou esse, em sua ideia como terra de utopia e fez das trajetórias a condição para uma expressão poética que lhe tornou própria.

O Brasil, a partir da vivência espacial e mitológica, passa a ser incorporado na obra de Blaise desde então, com veemente interesse. Observamos em sua produção duas criações, uma marcada pela imaginação com que produzia registros e analisava documentos, e outra posterior, em que o país era constantemente recriado em suas poesias.

Não desprezo absolutamente os documentos que são antes de tudo uma maravilhosa fonte de erros e de discussões. (...) a verdade se contradiz cem vezes por dia como boa tagarela que é. (...) por que não querem vocês que eu surja inteiro por trás de um documento, esportivo e alegre, e por que me recriminar várias distorções à verdade histórica? (...) E o que é a Verdade Histórica? E o que é um Documento? Uma interpretação sempre, tendenciosa ou artística. Um trampolim. Para mergulhar. Na realidade e na vida. No coração da matéria. (CENDRARS, 2008, p.266)

0 que interessava à Blaise no Brasil era um misto daquilo que tinha de exótico e das marcas de uma modernização rápida que o país sofria, principalmente em São Paulo, que ele lia como uma cidade nova, que se erguia muito rapidamente, sem observar suas tradições. As viagens que ele realizou iam de encontro com essa ambiguidade tão própria do processo modernizador brasileiro. Essas pluralidades se configuravam a partir do recurso da fantasia, da criação na obra do poeta e romancista.

Nesse mesmo ano, entretanto, partindo com os amigos paulistas à descoberta das cidades históricas de Minas Gerais, ele depararia 
na realidade com o Brasil que havia construído na fantasia ao mesmo tempo em que o revelava aos próprios brasileiros. Pode-se ter a viagem a Minas como o momento decisivo em que o Modernismo passa por sua mutação brazilianizante ou abrasileiradora, depois da fase internacionalista e vanguardista em que, como observava Cendrars sem indulgência, apenas macaquava o que se fazia em Paris. Por inesperado e quase inacreditável paradoxo, é Cendrars que força o Modernismo na sua guinada nacionalista. (MARTINS, 2001, p.496)

Depois de "Fouilles de Route", Cendrars se dedica mais a textos longos, mais explicativos, em prosa, como é o caso de "Prose du Transsibérien".

Os dois livros compartilham também, além da mesma concepção de viagem, o mesmo princípio de registro das impressões de viagem. Em certa medida, tanto em um como no outro, Cendrars faz uso da memória como recurso que serve para dar coerência às experiências vividas. (ALEM, 2011, p.57)

Além das obras textuais, Cendrars chegou a fazer um roteiro de um filme, que ficou na forma de projeto. 0 projeto do filme é mais um formato em que ele usou o que anotou das viagens brasileiras como matéria para pensar sua produção artística, em várias linguagens, como a cinematográfica, essa nova aventura em que Blaise se arriscou. A matéria brasileira era muito rica, como potencial, e segundo ele, merecia um desenvolvimento que desse conta de explorar todas essas nuances.

A ideia do filme era uma espécie de documentário sobre o Brasil, que, no entanto, não chegou a ser realizado, este projeto seria realizado em parceria com Oswald de Andrade.

Paulo Prado, amigo de Blaise foi seu correspondente durante o trânsito desse projeto e a quem ele primeiro apresentou a ideia, de um filme propaganda do Brasil, intitulado como "filme 100\% brasileiro", cheio de polêmicas acerca da sua produção.

Decide então fazer um filme para mostrar a floresta, os rios gigantes e o homem que aqui chega para construir-se uma nova pátria. Concebido como um grande filme de propaganda, contaria a história da formação do país, dos pioneiros da colonização aos modernos engenheiros que promoviam o progresso. (CALIL, 2008, p.16)

0 projeto do filme fica suspenso com a revolução que eclode em 05 de julho de 1925, na qual os ataques bombardeavam o Palácio do Governo e os bairros operários. Diante dessa situação política, Blaise, na condição de 
hóspede de Paulo Prado, se refugia em sua fazenda.

0 assunto só é retomado em diálogos com Paulo Prado, anos mais tarde, e projeto não tem andamento, por uma falta de entendimento entre Cendrars e as instituições que fariam o financiamento.

Em 1927, Blaise realiza mais uma viagem ao Brasil, na qual passa praticamente toda a temporada no Rio de Janeiro, e desse período, não há documentação em que o tema do filme volte á tona.

Do ponto de vista do cinema, o projeto é bastante esclarecedor, sobre tudo de um profissionalismo de que até hoje se duvida. Cineasta sem filme, Cendrars conseguiu a proeza, desde os anos 1920, de se fazer passar por um "homem do ramo", constata desconfiado Claude Leroy. Para ele, esse cinema é apenas "de papel". (CALIL, 2008, p.19)

Analisando tanto os relatos textuais quanto a busca por alternativas de representação produzidas por Blaise Cendrars, percebemos essa necessidade que o autor tinha de expressar as ideias, as impressões das experiências vividas por ele no tempo brasileiro, por considerar a matéria de forma hiperbólica, que merecia ser explorada de outras formas que não somente a linguagem escrita, em prosa ou poesia.

A ingenuidade e espontaneidade da primeira impressão ou pré-impressão que se tinha do país versus o interesse midiático e comercial reproduzido na ideia do país moderno do futuro iria produzir um cinema de propaganda política de conhecimento de Washington Luís, presidente do Estado de 19201924.

Entre os destaques do projeto está o planejamento da distribuição do filme, assim como a estratégia de sua exibição. De início localizada, para chamar a atenção do público, em seguida ampliando o circuito das salas, alude com certeza a experiências anteriores bem sucedidas. 0 jogo com a mídia, as ressonâncias comerciais obtidas com a exploração da trilha sonora em concertos e do roteiro romanceado em forma de livro, a previsão de duas versões do filme destinadas a platéias distintas - o conjunto das ações propostas é astucioso e premonitório. (CALIL, 2008, p.21)

Sabe-se que Cendrars visitou o Brasil novemente, em 1926, e depois durante os anos de 1927 e 1928, mas em relação ao impacto de sua primeira visita, em 1924:

O afastamento de Oswald de seus amigos, incluindo Paulo Prado

e Mário de Andrade, atacados na revista Antropofagia, atingiu Cendrars, que ficou do lado de Prado. A crise econômica de 1929, 
que afetou fortemente a economia exportadora brasileira e secou boa parte da fonte que alimentava os ímpetos artísticos dos paulistas, pôs um fim definitivo aos movimentados anos 1920, ao casamento de Tarsila e Oswald, e à relação de Cendrars com nossos modernistas. (BATISTA, 2011, p.155)

- m.a.

Mário de Andrade se forma bacharel em Ciências e Letras em 1909, e já em 1910 ingressa no curso de Filosofia da Faculdade de Filosofia e Letras de São Paulo. Nesse mesmo ano de 1910, inicia seus estudos no Conservatório Dramático e Musical de São Paulo, estudando piano, aonde chega a dar aulas.

Começa a dialogar com Anita Malfatti e Oswald de Andrade, que fundam em conjunto o movimento modernista brasileiro. Desde então foi travando relacionamentos com outros artistas e intelectuais. Participa da Semana de Arte Moderna, no Teatro Municipal de São Paulo, de 13 a 18 de fevereiro de 1922.

O percurso de formação de Mário de Andrade foi muito plural, percorrendo por entre diversos meios artísticos, como a música, a poesia, o folclore, os ritos culturais a apreciação pela pintura, pela arquitetura.

Marcelo Burgo Pimentel dos Santos (2012) olha para a atuação de Mário de Andrade como intérprete do Brasil a partir de três eixos, denominados por ele como: "homem literato", "homem público" e "homem pesquisador":

0 primeiro eixo, o "homem literato", aborda sua produção literária juntamente com o período das viagens, do início do modernismo:

[...]'homem literato', o reconhecido escritor de romances, poemas, contos e crônicas. Por essa perspectiva, foi personagem e nomechave do modernismo brasileiro, autor de obras consagradas na literatura brasileira: Macunaíma, o herói sem nenhum caráter; Pauliceia Desvairada; Amar, verbo intransitivo, entre outras. Macunaíma, aliás, foi produzido junto com outras obras importantes do final da década de 20, no momento mesmo em que ele está "redescobrindo" o Brasil através de suas viagens. (SANTOS, 2002, p.16)

Já o segundo eixo aborda o período em Mário atuou junto de instituições públicas, como dirigente e propositor de práticas patrimoniais, atenta-se ainda para o fato de que o primeiro momento, onde se dão as primeiras viagens, contribuiu para a forma como conduziu essas instituições: 
[...]'homem público' que assumiu a chefia do Departamento de Cultura, entre os anos 1935-38. Mário de Andrade foi o principal idealizador (ao lado de Paulo Duarte) e primeiro diretor daquele departamento, que 50 anos mais tarde inspiraria a criação do Ministério da Cultura (MinC) do Brasil. É nesse momento que Mário de Andrade, o homem 'público', coloca o Departamento de Cultura como um modelo de pesquisas sobre a cultura brasileira. (SANTOS, 2002, p.17)

Aqui, o "homem pesquisador", faceta que perpassa as outras duas, se dá a partir dos primeiros eixos de atuação, mas é sempre um eixo norteador de sua obra:

[...]'homem pesquisador', pela tentativa de interpretação do Brasil. Como já mencionado, essa vertente, que o faz pesquisar material e livros sobre o Brasil, subsidiam sua produção literária e também suas ações de 'homem público'. (SANTOS, 2012, p.17)

Todas essas facetas de sua atuação se relacionam umas com as outras, em contribuição, enriquecendo-as. Complementa Marcelo Burgos Pimentel dos Santos (2002):

Acreditamos que Mário de Andrade foi um sujeito político sob duas perspectivas: a primeira, como participante ativo de um debate público (com o projeto modernista), que propunha reformulações e intervenções artísticas e culturais, com claros interesses estéticos, mas também ideológicos(...). Também consideramos o autor como político no sentido da carreira institucional, como 'homem público' que institucionalizou o campo cultural na política brasileira. Propomos pensar a esfera do sujeito cultural atuando na política, pois Mário de Andrade sempre teve como preocupação, demonstrada em diversos momentos de sua obra, a função social do artista. Ou seja, o papel do artista no conjunto da sociedade. Assim, também como político observamos o pilar 'homem pesquisador', uma vez que sua atuação baseou-se em práticas metodológicas de cunho científico, que reverberaram na sua atuação institucional. (SANTOS, 2012, p.19)

Essa ampla atuação institucional que Mário de Andrade teve foi uma resposta às suas pesquisas, o que ele observou e coletou nas viagens, para além do emprego como insumo para o desenvolvimento de uma linguagem literária, Mário trouxe a reflexão das viagens para o âmbito institucional, como proposta estética, e como sugestão na forma de ver o patrimônio cultural do Brasil.

Desenvolve dois projetos que repercutem até hoje quando se pensa a institucionalização da cultura brasileira: a Missão de 
Pesquisas Folclóricas e a Sociedade de Etnologia e Folclore.

(SANTOS, 2012, p.19)

\section{_mario viajante}

Mário foi um personagem desses que com quem a viagem sempre esteve presente, a viagem de estudos. Podemos supor que nunca parou de viajar, no sentido em que ele sempre voltou aos fragmentos de suas viagens, reescrevendo-as, reformulando-as, retoricamente.

Mário de Andrade não foi apenas o grande escritor de literatura ou o homem ligado às artes, embora talvez essa seja sua face mais conhecida. Há outra dimensão fundamental para entender sua importância: ele também foi um intelectual, pensador que viajou e estudou para melhor compreender o Brasil e os brasileiros, fundamentalmente no campo cultural. (SANTOS, 2012, p.16)

O sentido e o programa das viagens em Mário de Andrade foram a busca pela origem, pelo que primitivo, primordial, os indícios primeiro da manifestação artística brasileira, em seu caráter autônomo, não mais subordinado, censurado de perto pela cultura portuguesa.

[...] a obra de Mário de Andrade também guarda uma preocupação com a pesquisa e, por isso, faz da literatura uma forma de entender o Brasil. (SANTOS, 2012, p.189)

A literatura reflete a pesquisa, e como meio, produz, inventa linguagem. A linguagem que ambiciona a singularidade, a síntese. Nesses termos, a pesquisa alimenta literatura em Mário de Andrade.

A literatura que Mário produziu não foi um registro do instante da viagem, a literatura "marioandradina" teve como desafio, proposto pelo próprio escritor ${ }^{22}$, a complexa tarefa de conjugar a orientação moderna com a realidade local, sem cair no risco do regionalismo.

Mário conjugou em seu modo de pesquisar, experiência "in loco" e atuação institucional, visualizando os dois polos como complementares, na medida em que sua produção é profundamente influenciada pela memória, pela reflexão do que foi vivido no tempo que passou nas viagens.

Para o modernista Mário de Andrade, empenhado em entender a realidade brasileira dentro de um quadro latino-americano e em traçar, na medida de suas possibilidades, as coordenadas de uma cultura nacional, tomando o folclore e a cultura popular 
como instrumentação para seu conhecimento do povo brasileiro, foi muito importante unir pesquisa de gabinete e vivência de vanguardista metropolitano ao encontro direto com o primitivo, o rústico e o arcaico, que, em seu enfoque dialeticamente dinâmico, puderam lhe valer como indícios de autenticidade cultural. (LOPEZ, 2015, p.15)

A primeira viagem com essa conotação de viagem de estudos foi realizada em 1918, enquanto congregado mariano, aos arredores de São Paulo, por Osasco, Pirassununga e Fazenda da Barra. Essa primeiro contato em campo instigou Mario e conhecer outras regiões do Brasil, para além das fronteiras do Estado de São Paulo.

Nas férias de junho de 1919, enquanto diretor do Conservatório Dramático e Musical de São Paulo, tendo como destino as cidades mineiras. 0 roteiro inicial que Mário havia programado consistia em visitar Mariana, e também a visita para o poeta Alphonsus de Guimaraens (1870-1921). Mário deixa São Paulo de trem, e desembarca primeiramente na capital Belo Horizonte, seguindo depois às cidades históricas, nas quais teve seu primeiro contato com manifestações artísticas do barroco mineiro.

Mário viaja sozinho, e em trânsito, já imagina a sua próxima pesquisa, que culminaria na viagem a Minas na semana santa de 1924.

Minas - como Mário afirmava - era considerado o Estado onde a brasilidade teria se desenvolvido de maneira mais espontânea e autêntica, uma vez que estava mais distantes dos centros litorâneos e sofria, por isso mesmo, menos influência da metrópole portuguesa. Nas Gerais residia esquecido o Brasil primitivo, o Brasil de Aleijadinho e do barroco mineiro, o país em suas primeiras manifestações identitárias e tradições históricas. (NATAL, 2007, p. 203).

Dessa primeira aproximação com o barroco mineiro, que aconteceu nessa viagem em 1919, Mário escreveu um conjunto de quatro crônicas intituladas: "A Arte religiosa no Brasil - Triunfo Eucarístico de 1733", "A Arte religiosa no Brasil - Arte Cristã", "A Arte religiosa no Rio" e "Arte religiosa no Brasil - Em Minas Gerais". Essas crônicas foram publicadas separadamente, em edições da "Revista do Brasil", e posteriormente reunidas no conjunto "A Arte religiosa no Brasil".

Esse é o registro em prosa recortado para essa leitura, mais precisamente a última crônica.

Em 1924, volta então a Minas Gerais. Passam por Juiz de Fora, Barbacena, 
São João del Rei, Tiradentes, Belo Horizonte, Ouro Preto, Mariana e Congonhas na "viagem de redescoberta do Brasil". Mário teve um papel peculiar dentro do grupo que percorre essa viagem, por já ter feito um roteiro semelhante cinco anos antes, e é conferido a ele um papel de instigador dessa viagem no meio intelectual e artístico que frequentava.

Os elementos da cultura popular com os quais Mário se deparava nas viagens influenciavam diretamente as produções literárias que o autor estava desenvolvendo, e não raras vezes, as viagens eram motivadas pelo trabalho que ele escrevia no momento, a conotação dos escritos literários de Mário exigiam essas pesquisas, e assim nosso personagem partia em viagem com essas questões em mente.

\section{_literatura e registro em "A Arte religiosa no Brasil"}

A crônica desenvolvida no conjunto "A Arte religiosa no Brasil" é uma descrição em 1a pessoa, que não narra sequencialmente o roteiro, das passagens por cada cidade, edifícios ou monumentos, mas narra a experiência que o viajante teve do conjunto, e para isso utiliza da memória, do que lhe causou mais impacto.

O que Mário realiza em suas viagens é uma pesquisa artística através da leitura de manifestações escultóricas, decorativos e de elementos intrínsecos à arquitetura, como composição, planta, volumetria, colunas, o tom do texto é de uma descrição densa, minuciosa, a qual revela um alto grau de familiaridade aos termos construtivos.

Figura 23: VILLA, 2018. Foto da capa de "Arte religiosa no Brasil", Experimento Giordano (1993). FONTE: Acervo da autora.

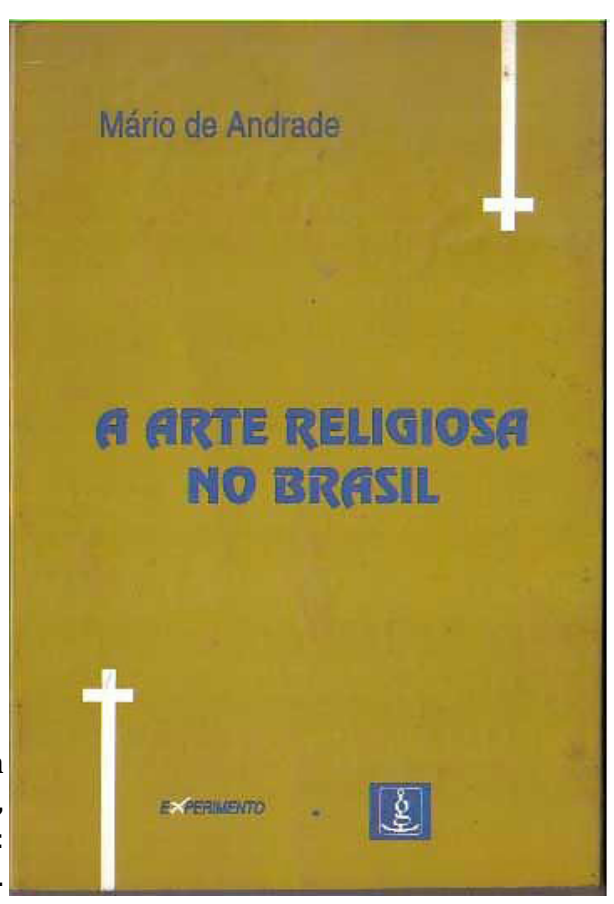


A primeira crônica Arte religiosa no Brasil - Triunfo Eucarístico de 1733" expõe as festividades religiosas que compõem os objetos primeiro de estudo de Mário na viagem, as construções civis religiosas. Nesse texto, dá importância ao conceito de patrimônio cultural em dois termos, a descrição da "pompa" e a "influência do sensível". Mário escreve num intuito de compreender os ritos, dá valor cultural à eles.

A segunda parte, "A Arte religiosa no Brasil - Arte Cristã" se desenvolve numa narrativa parecida com a primeira, como conclusão, explorando os conceitos, as origens de símbolos, como a "cruz" na cultura brasileira.

Nessas duas primeiras crônicas, Mário descreve o contexto histórico do desenvolvimento do Barroco no Brasil, e apresenta, três escultores, cada um representativo da produção de uma região, as regiões que ele elege são: a Bahia, o Rio de Janeiro e Minas Gerais, com uma predileção pela última.

Desenvolvida em rápida escala, a arquitetura religiosa ilhouse em três centros principais: Bahia (a que também se ajuntará Pernambuco), Rio de Janeiro e Minas. [...] Na Bahia, o Barroco atinge uma expressão menos sincera, a construção é mais erudita; no Rio de Janeiro a preocupação artística exterior diminui ao passo que a decoração interna atinge ao delírio, produzindo a obra-prima do entalhe que é a igreja de S. Francisco da Penitência; em Minas, vamos deparar a suprema glorificação da linha curva, o estilo mais característico, duma originalidade excelente. Três escultores dominam nesses três centros: Chagas, 0 Cabra, na Bahia; mestre Valentim, no Rio de Janeiro: Antonio Francisco Lisboa nas Minas Gerais. (ANDRADE, 1993, p. 50).

Das construções civis e religiosas visitadas em Minas durante o ano de 1919, Mário se atenta mais, na análise e descrição desse ensaio às manifestações religiosas, são nelas que ele encontra a expressão máxima da elegância e do desenvolvimento dos conceitos do Barroco "abrasileirado".

Mário faz um elogio, em muitas das passagens do texto ao tom "mais simples", "mais pobre", quase sóbrio do estilo em sua expressão brasileira, nas próprias edificações religiosas:

Todas essas igrejas, assim como os templos de maior porte, edificados mais tarde, obedecem a uma certa ordem de tipos arquitetônicos que, tendo-se vulgarizado por todo o Brasil, tomaram uma feição fortemente acentuada, donde muito bem se poderia originar um estilo nacional. 0 jesuítico, o plateresco, o rococó - que mais não são que um só estilo com mínimas variantes, provenientes dos países onde assim se denominou 
o estilo barroco, - aí domina, porém mais simples, mais pobre, menos pedantesco. (ANDRADE, 1993, p. 47).

Na terceira crônica, "A Arte religiosa no Rio", Mário fala especialmente das vielas que compõem com a Avenida Central, num elogio ao conjunto arquitetônico que se é possível identificar, da singeleza das edificações.

Em "Arte religiosa no Brasil - Em Minas Gerais", quarta e última crônica do conjunto, o autor começa descrevendo o desenvolvimento das regiões urbanas de Minas Gerais, descrevendo as cidades como "sobreviventes", depois de lhes retirada todo o ouro de suas terras. Nomeia "Vila Rica"23, "centro de fausto", Mariana, "centro de instrução" e São João del Rei, "centro de heroicidade". E define a dinâmica das cidades como "meio oscilante de inconstâncias em que se desenvolveu a mais característica arte religiosa do Brasil" (ANDRADE, 1993, p.78).

Continua, em uma defesa do que as cidades mineiras pareciam ter sido, para Mário, o ambiente profícuo para o desenvolvimento inovador, original do estilo Barroco. Segundo Mário, os "construtores portugueses mais aclimados", produziram um Barroco de "caráter bem mais determinado, muito mais nacional”, e afirma, “Em Minas, o estilo barroco estilizou-se” (ANDRADE, 1993, p.78).

Nesse fragmento, Mário parece justificar a escolha de sua viagem, defendendo os olhares possíveis que quis pousar sobre Minas Gerais:

[...]talvez a minha audácia de encontrar genuínas obras de arte nacional na colônia seja tida por vesânia ou tomada à guisa de exaltado patriotismo. Asseguro-vos que não agi assim. Vi, com olhos de ver, o que por aí havia de defeitos e qualidades. Num trabalho que não é positivamente crítico, eu não poderia esmiuçar nem estas e muito menos aquelas. Limitei-me a contar-vos que há por este grande Brasil lindas coisas, que à Igreja devemos, e que podem ser vistas, não só com olhos sentimentais de patriota, com olhos humildes de crente, mas com olhos enlevados de artista. Não censuro o brasileiro que quer ver Paris, desejaria apenas que ele visse a Bahia, o Rio das vielas estranguladas que ladeiam a Avenida Central e principalmente abrisse o Sésamo acolhedor e encantado de Minas. (ANDRADE, 1993, p.89)

Os olhos que o viajante escolheu foram os "olhos enlevados de artista", olhar encantado, em êxtase. E é a partir dessa sensibilidade que Mário compreende a presença e a obra do "escultor-arquiteto" Aleijadinho.

Aleijadinho foi descrito por Mário nas páginas dessa crônica final, como 
"gênio", discorre sobre a falta de instrução do artista, se queixando, mas ao mesmo tempo fala sobre o caráter impressionante, impactante e forte de sua produção, da impressão que suas obras lhe causaram.

Toda arte rudimentar deriva ou para a observação fiel da natureza, ou, em razão das suas poucas forças, para a idealização do que não se pode reproduzir; todo gênio inculto tende para o realismo ou para a estilização. 0 artista das cavernas pré-históricas foi assim. O Aleijadinho, em última análise também assim foi: apenas a sua potência criadora, se tantas vezes produziu obras dum realismo incorreto, pôs uma alma dentro de cada pedra que abastou. (ANDRADE, 1993, p.84)

Mário insiste na descrição da força com que foi afetado pela produção de Aleijadinho, principalmente pelos profetas no conjunto de Congonhas: "Congonhas do Campo é o maior museu de escultura do Brasil" (ANDRADE, 1993, p.86)

Mário via Aleijadinho como o legítimo representante da originalidade, do conceito de "aclimatado", e volta a falar dele em outros textos, como em 1928 no livro "O Aleijadinho e Álvares de Azevedo":

O Brasil deu nele o seu maior engenho artístico, eu creio [...]. Era, de todos, o único que se poderá dizer nacional, pela originalidade das suas soluções. Era já um produto da terra, e do homem vivendo nela, e era um inconsciente de outras existências melhores de além-mar: um aclimatado, na extensão psicológica do termo. (ANDRADE, 1984, p.41) ${ }^{24}$

Queixa-se, na conclusão das páginas de "Os nossos tempos", no final do volume de "A Arte religiosa no Brasil", da arquitetura das Igrejas "imitadoras", que ele via crescer em São Paulo e no Rio de Janeiro. No sentido inverso dessa tendência, ele entende as capelas e Igrejas de Minas, nas quais os elementos decorativos não residiam somente na decoração posterior, mas era notada nos planos e volumes da edificação.

Em um contraponto a essa queixa de Mário, os artistas, artesãos e construtores brasileiros:

Ao invés de simplesmente importar os modelos metropolitanos, através da cópia rude ou do plágio grosseiro, estes artistas procuraram inovar, transformar tais modelos, acrescentar espontaneamente concepções e soluções próprias, de modo a fabricar um estilo distinto, único. (NATAL, 2007, p. 193)

24 Ensaio escrito em 1928 e publicado no livro O Aleijadinho e Álvares de Azevedo. Rio de Janeiro: R. A. Editora, em 1935. 


\section{_"viagens etnográficas" a partir de 1927}

Depois da viagem junto do grupo modernista em 1924, Mário faz as denominadas por ele mesmo como "viagens etnográficas". Nessas viagens, de 1927 pelo Amazonas e nas de 1928-1929 para o Nordeste, Mário se dedica à produção de diários escritos e o do fotógrafo, o diário por conservar uma estrutura de fatura e de publicação fragmentária, que proporciona ainda hoje uma leitura aberta.

A primeira viagem ocorreu entre 7 de maio e 15 de agosto de 1927, e o escritor modernista viajou acompanhado por três mulheres, capitaneadas pela amiga D. Olívia Guedes Penteado - uma das mecenas do modernismo brasileiro. As outras duas eram Margarida Guedes Nogueira, sobrinha de D. Olívia e Dulce do Amaral Pinto, filha de Tarsila do Amaral. (SANTOS, 2015)

Um aspecto dos comportamentos de viagem observados em Mário de Andrade é o de nunca perder a interlocução com outros pesquisadores, intelectuais com quem dialogava e debatia na época, das viagens.

Desde o momento de preparação, durante e também posteriormente, ao período das viagens etnográficas, Mário de Andrade dialoga com interlocutores e conhecidos, com quem se corresponde e mantém contato. (SANTOS, 2015)

Para Mário, as viagens foram um método de pesquisa sempre presente em sua trajetória, e o contato que ele teve com um Brasil amplo e complexo nessas experiências impulsionaram o escritor à uma atuação política, em órgãos públicos cada vez mais abrangente também:

É que, desde as viagens, cada vez mais o escritor atuava como intelectual público, talvez o grande intelectual público do país à época, engajado na organização da cultura e na constituição de um dos pontos de vista mais originais, complexos e abertos do Brasil, graças ao trabalho permanente de pesquisa, interpretação, crítica e divulgação das artes, de atuação junto à imprensa, de formulação de políticas e instituições, de estabelecimento e preservação de um patrimônio cultural nacional. (LIRA, 2015, p. 336) 


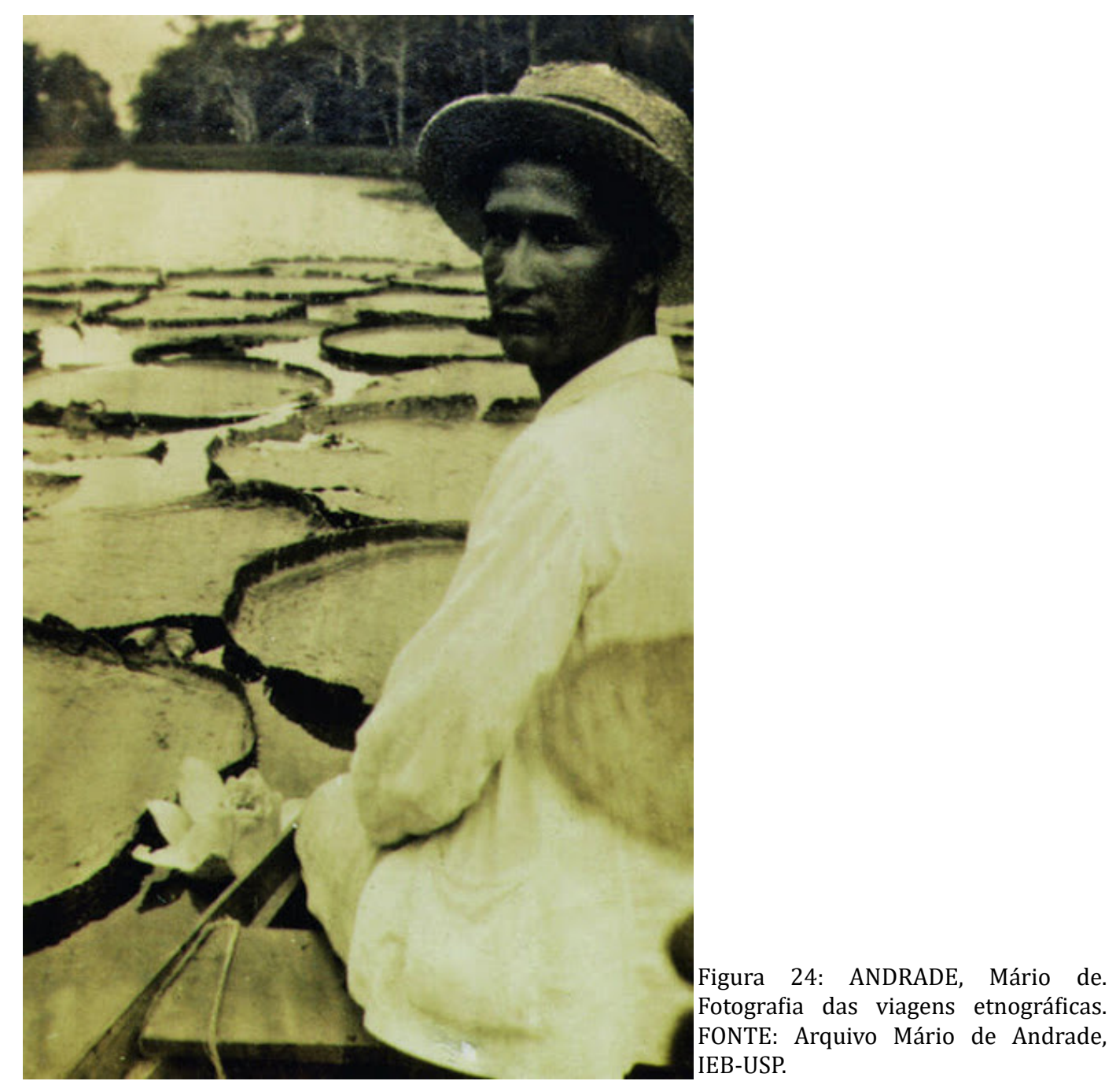

Para José Lira (2015), as viagens de Mário a partir de 1927 intensificaram “jogos de identificação e extravio, desterritorialização e enraizamento, elaborados em meio aos relatos da paisagem, do caráter e da cultura de algumas cidades brasileiras."

Mário de Andrade teve uma larga atuação como fomentador de transformações políticas e institucionais importantes no Brasil, como a Missão de Pesquisas Folclóricas e a Sociedade de Etnologia e Folclore, e os conceitos que vieram a influenciar Mário nesse seu leque de atuações começaram a ser desenvolvidos nos contatos do escritor-viajante em campo, no contato com as manifestações culturais brasileiras tradicionais.

Lira aponta para a hipótese de que o imaginário patrimonial brasileiro tenha se modelado, em grande medida na referência de viagem de Mário de Andrade, para além da viagem ser somente considerada uma decorrência de um processo já em exploração no campo da formação do ideário preseracionista.

Nesse sentido, a viagem de Mário ajudou formar e reformular os métodos 
e a trazer referências novas para a cultura patrimonial nacioal.

As viagens de Mário podem ser lidas inicialmente através de uma chave romântica, nacionalista, mas trouxe uma novidade, a inserção nos novos roteiros, um olhar para além das regiões metropolitanas, um olhar para os costumes e cultura de uma população mais plural do país. Essa postura de pesquisador, antropólogo, trouxe novas referêcias para uma já existente tradição científica e literária qe vinha se constituindo desde meados do século XIX. Essa escolha de postura teve o impacto de colaborar com a construção dessa tradição, de políticas de preservação no país, pela posição social e intelectual de Mário na sociedade.

Mário propõe como via de acesso à cultura brasileira pouco explorada o contato direto com as fontes primárias, o tempo "em campo", e, a partir desse método de viagem, registrou em seu diário os sentimentos que a imsersão lhe proporcionou. 0 tempo "em campo" fornece tanto os elementos físicos quanto os princípios de ordem mais abstratas, o juízo estético, político que o viajante elabora em viagem, conjunto denso com os quais o viajante construiu suas narrativas culturais nacionais.

A instância da viagem é aquela que compreende personalidades, desejos, inseguranças, riscos. 0 encontro que se presencia em viagem não é só objetividade, na questão da busca do nacional, a viagem proporciona um "reencontro do espaço, da cultura e do projeto nacionais no deslocamento, no desvio, na descoberta de seus vícios e nas possibilidades latentes." (LIRA, 2015, p.291) 


\section{_relatos visuais}

Dentro desse tipo de registro, encontramos dois de nossos personagensviajantes que produziram desenhos, croquis, levantamentos de viagem, Tarsila do Amaral e Lúcio Costa.

Tarsila colecionou, de sua viagem, três séries de desenhos, feitas em momentos diferentes da mesma viagem, são elas: a série de desenhos do carnaval, no Rio de Janeiro, parte inicial da viagem que depois chega a Minas Gerais, dando o volume ao conjunto de aproximadamente 120 desenhos da segunda, série de Minas, e a terceira série identificada corresponde aos 8 desenhos que ilustraram a primeira versão da publicação de Le Formose, poemas do viajante Blaise Cendrars.

De Lúcio Costa, para essa análise, recortamos os desenhos produzidos em sua viagem a Diamantina, realizada no ano de 1924, enquanto Lúcio ainda era estudante de arquitetura da Escola Nacional de Belas Artes (ENBA), no Rio de Janeiro. Os desenhos que Lúcio trouxe dessa viagem apresentam um tom de documentação, de levantamento do patrimônio histórico que começara a ser catalogado nessas experiências de viagem, tanto de Lúcio, quanto de outros estudantes e professores.

\section{_t.a.}

O percurso de formação artístico de Tarslia teve início com o trabalho com escultura ${ }^{25}$ em 1913, em 1917, iniciou os estudos de pintura e desenho com Pedro Alexandrino (1864-1942), e nesse mesmo ano constrói seu ateliê de artista, um dos primeiros de São Paulo.

É em 1920 que faz o que podemos classificar como sua primeira viagem de estudos, na Europa, fixa-se em Paris e passa a estudar na Académie Julian ${ }^{26}$. Nesse mesmo ano, quando vem ao Brasil, Tarsila começa a se relacionar com outros artistas modernistas, ligando-se ao Grupo dos Cinco, em São Paulo, do qual eram integrantes: Anita Malfatti, Menotti del Pichia, Oswald de Andrade e Mario de Andrade. Após essa experiência, sua pintura passa por uma rápida transformação, que coincide com a viagem a Veneza, Itália, a residência em

25 Em 1913, começa a trabalhar no ateliê de Wiliam Zadig (1884-1952), escultor sueco radicado em São Paulo.

26 Foi uma escola de pintura e escultura, fundada em Paris em 1867 pelo pintor Rodolphe Julian, que ficou famosa que a frequentaram nos anos 1920, como Marcel Duchamp, Édouard Vuillard e Henri Matisse. 
Paris e um breve retorno ao Brasil em junho de 1922.

Em 1923, viaja com seu marido Oswald de Andrade por Portugal e Espanha. Nesse mesmo ano também conhece Blaise Cendrars, poeta que se tornaria um grande amigo.

É nesse período, entre 1922 e 1923 que Tarsila realiza estudos com artistas cubistas, como Lhote, Gleizes e Léger ${ }^{27}$, com destaque principal para o pintor Léger, com quem Tarsila teve aulas na França, a convivência entre os dois foi marcante no seu percurso de formação, foi uma convivência de muita troca, se por um lado Tarsila aprendeu com ele as técnicas cubistas, o conceito de composição, e emprestou o método de criar a cena na tela por planos coloridos, a pintora brasileira deixou em Paris a temática que começara a identificar no Brasil, do primitivo, do exótico.

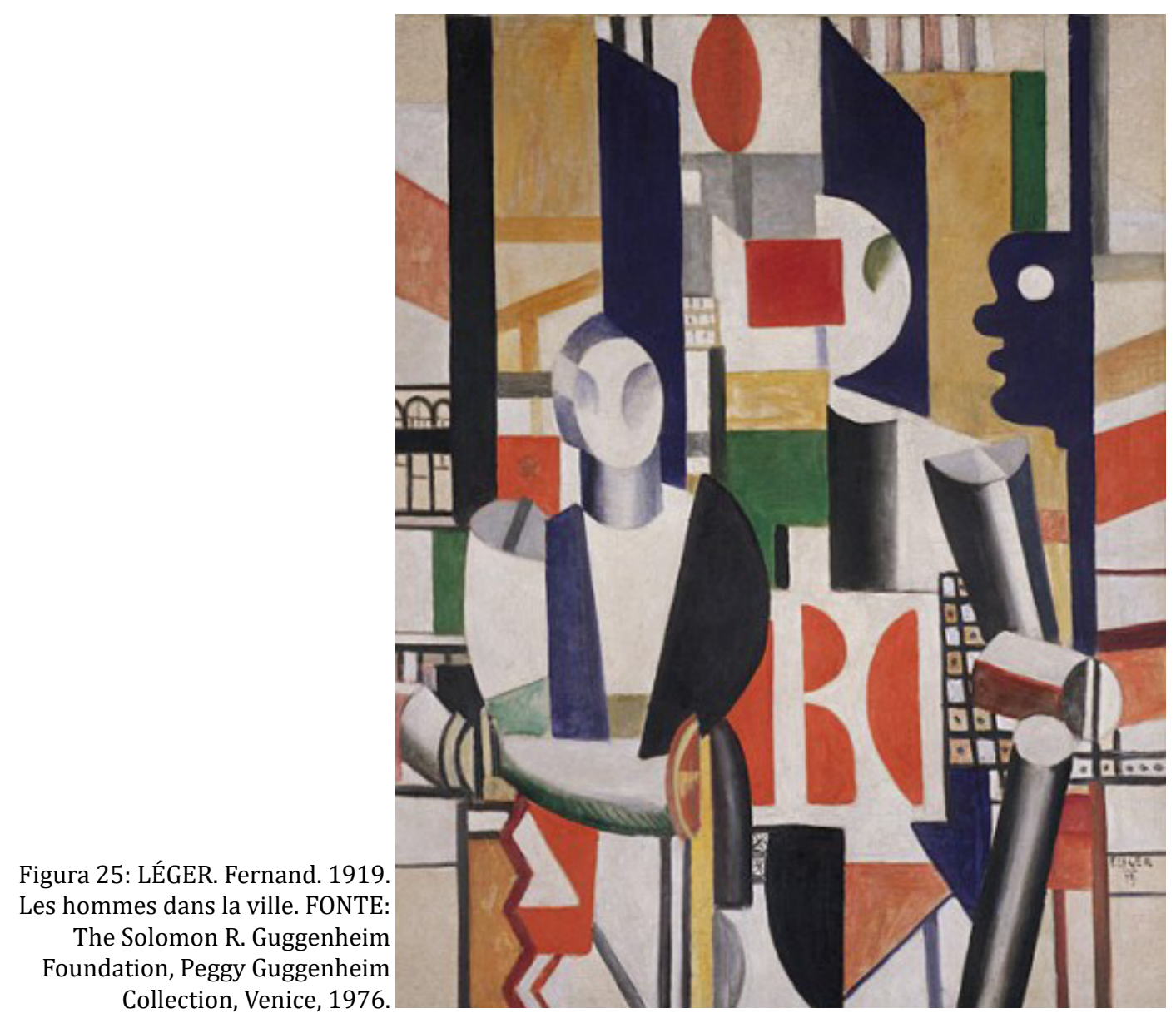

27 Fernand Léger (1881-1955), pintor e desenhista de influências cubistas, com quem Tarsila estuda e constrói uma amizade no seu tempo de permanência na França. 
As viagens tiveram um papel importante na formação de Tarsila, antes da viagem de 1924, o itinerário europeu por ela percorrido trouxe um desejo por revelar o Brasil ao mundo, na medida em que constituía uma rede de contatos entre artistas e intelectuais interessados em discutir as vanguardas, a incorporação do exótico na arte, e ela se via imersa nessa atmosfera.

Em 1924, ano em que Tarsila faz a viagem entre fevereiro, março e abril, entre o Rio de Janeiro e Minas Gerais, a pintora tem seus questionamentos acerca das referências que havia colecionado entre viagens e professores, colegas.

Impregnada pelo cubismo, teórica e praticamente, só enxergando Léger, Gleizes, Lhote, meus mestres em Paris; depois de diversas entrevistas sobre o movimento cubista, dadas a vários jornais brasileiros, senti, recém-chegada da Europa, um deslumbramento diante das decorações populares das casas de moradia de São João Del Rei, Tiradentes, Mariana, Congonhas do Campo, Sabará, Ouro Preto e outras pequenas cidades de Minas, cheias de poesia popular. Retorno à tradição, à simplicidade (TARSILA apud EULÁLIO, 2001, p.112).

Pintora emblemática do modernismo nas artes no Brasil, Tarsila integra o quadro dos personagens selecionados nesse estudo, pois desde o início de sua formação dialoga e mantém relações pessoais e intelectuais com os outros personagens, Mário de Andrade e Blaise Cendrars, que integraram a "caravana" de 1924.

Nessa medida, os personagens da viagem se encontravam já como um grupo coeso antes mesmo da excursão, os personagens eram colaboradores uns dos outros, em seus escritos, ideias, referências, diálogos.

Considerando o percurso formativo de Tarsila, entendemos a viagem se 1924 como uma oportunidade de aprofundamentos dos estudos, técnicas e olhares sobre o nacional na arte, tema que Tarsila já tinha entrado em contato, de maneira gradual, em outras situações até esta da viagem, que foi sim, relevante, mas não foi primeira vez que o tema se desvela à artista, inclusive ela faz o roteiro motivada por essas ideias iniciais e contatos que havia feito até então.

Tarsila encontrou em Minas a personificação em cenário dos questionamentos que vinha construindo desde as primeiras aventuras europeias. É a partir de 1924 que a temática principal de sua obra se concentra no país. Suas pinturas parecem querer provocar um sentimento, ou ainda um desconforto em relação ao conceito de pertencimento e reconhecimento no 
nacional.

Sua visão de modernidade foi moldada durante viagem a Minas Gerais, que significou uma oportunidade de formação para a pintora, de contato com o tema que perseguia em suas pinturas, no espaço e no tempo da trama de seus questionamentos na época, ao mesmo tempo em que aprendia a assimilar os modelos europeus vanguardistas, como apontou Batista (2011, p.139).
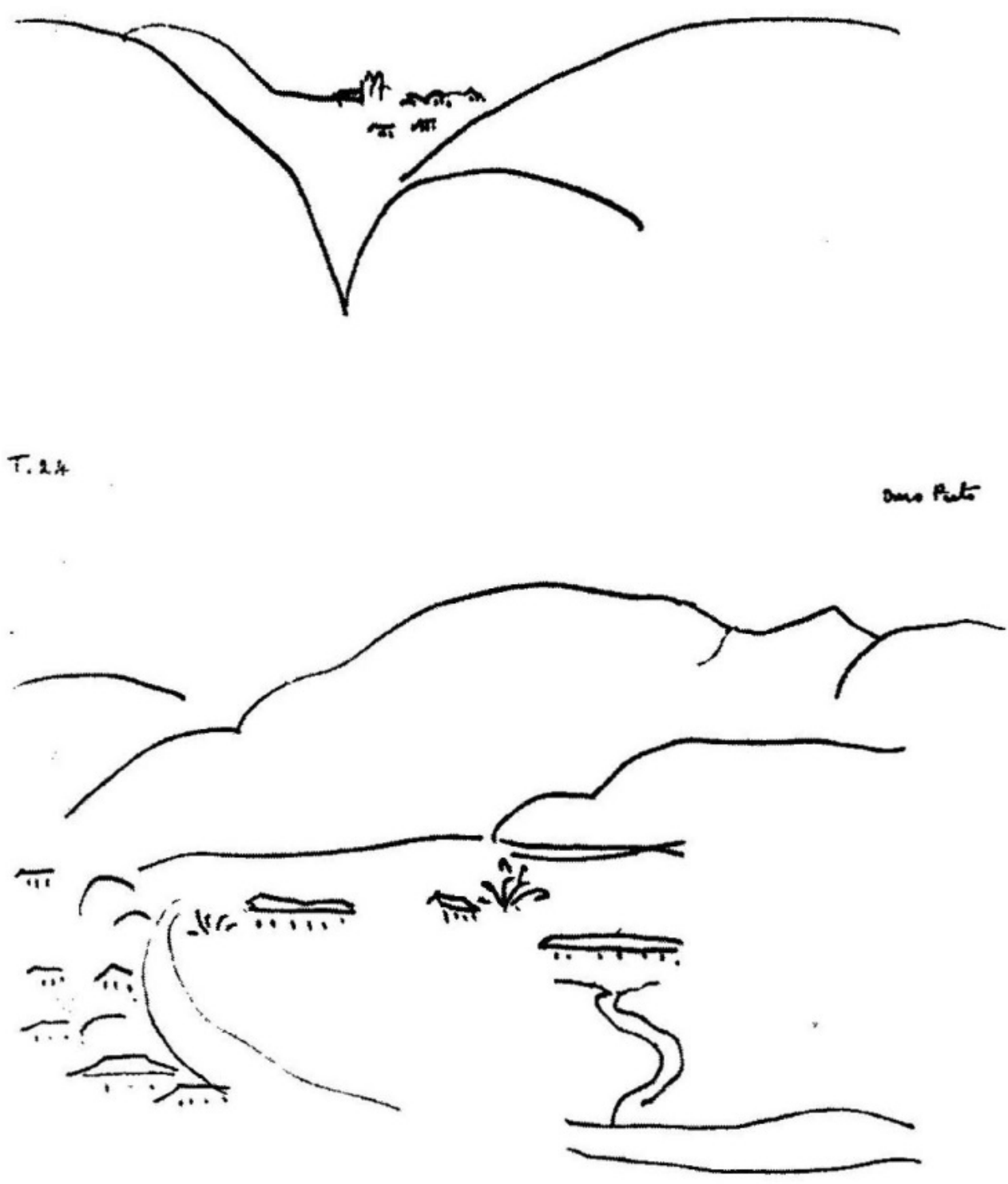

T. 2., 
Podemos falar em pesquisa artística do Brasil a partir da observação dos registros produzidos nas viagens, esboços, em um esforço de investigação da visualidade brasileira e a vontade de compreender a temática fornecida pela paisagem. Essa fase que ficou identificada na obra de Tarsila desde as viagens de 1924 é a Pau Brasil a partir de Minas, com a exploração de cores e temáticas.

Essa fase que ficou identificada na obra de Tarsila desde as viagens de 1924 é a Pau Brasil a partir de Minas. Cores e temáticas.

Fase Antropofágica de seu trabalho, por sua vez, é a que identificamos a partir de 1928. Da pintura de "Abaporu", que significa "homem que come carne", antropofágico. 0 quadro, junto do texto manifesto escrito por Oswald foram os elementos com os quais o casal funda o movimento Antropofágico, a alusão ao gesto de comer, no batismo do movimento, se referia ao que, alegoricamente se pretendia fazer com as referências culturais europeias, digeri-las, e nesse processo, transformá-las em algo diferente, como alquimia, dando à elas um sentido brasileiro.

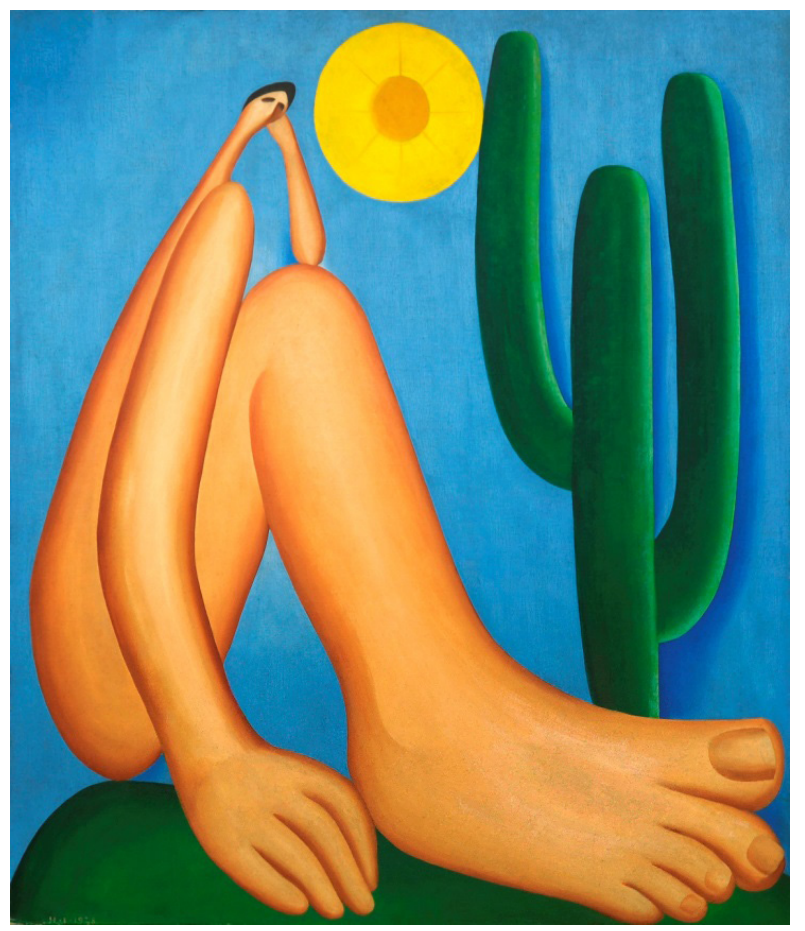

Figura 27: AMARAL, Tarsila do. 1928. O Abaporu. FONTE: Catálogo Raisonné Tarsila do Amaral.

Tarsila continuou sua investigação da temática brasileira, através da viagem e do fazer da pintura, inserindo mais fortemente um viés de crítica social, temática que fica mais evidente em sua obra a partir de 1930. 


\section{- o desenho como registro de viagem}

Os conjuntos de desenhos de Tarsila do Amaral, dentre todos os personagens viajantes analisados é o mais volumoso, cerca de 50 desenhos, disponíveis na base digital do Catálogo Raisonné da artista, e foram divididos para essa análise, em séries, de acordo com cada período da viagem. Essa é também uma classificação usada pela base de dados de onde foram coletados todos os arquivos da Tarsila para essa pesquisa. A mesma viagem brasileira de Tarsila do Amaral em 1924 pode ser pensada, em termos de registro, e de tempo, em duas séries, respectivamente, série do Carnaval e série de Minas.

A outra série de desenhos sob a qual se reporta essa análise são os oito desenhos que Tarsila faz para ilustrar "Feuilles de Route", de Blaise Cendrars. Esses desenhos foram realizados em Paris, em setembro de 1924.

Tarsila desenhava muito em suas viagens, usava o desenho como meio de apreender a paisagem e sua visualidade, desenho insistente, dos croquis coletados, observamos vários com o mesmo tema, como se a compreensão se desse pela repetição do traço.

A forma de registro das impressões que a viagem causou na artista é de ordem fenomenológica, na medida em que capta a visualidade do lugar, seu contexto, como imersão naquele momento.

\section{_ desenhos da série ilustrações, de "Feuilles de}

\section{Route"}

Figura 28: AMARAL, Tarsila do. 1924. Capa de "Feuilles de Route". FONTE: Catálogo Raisonné Tarsila do Amaral

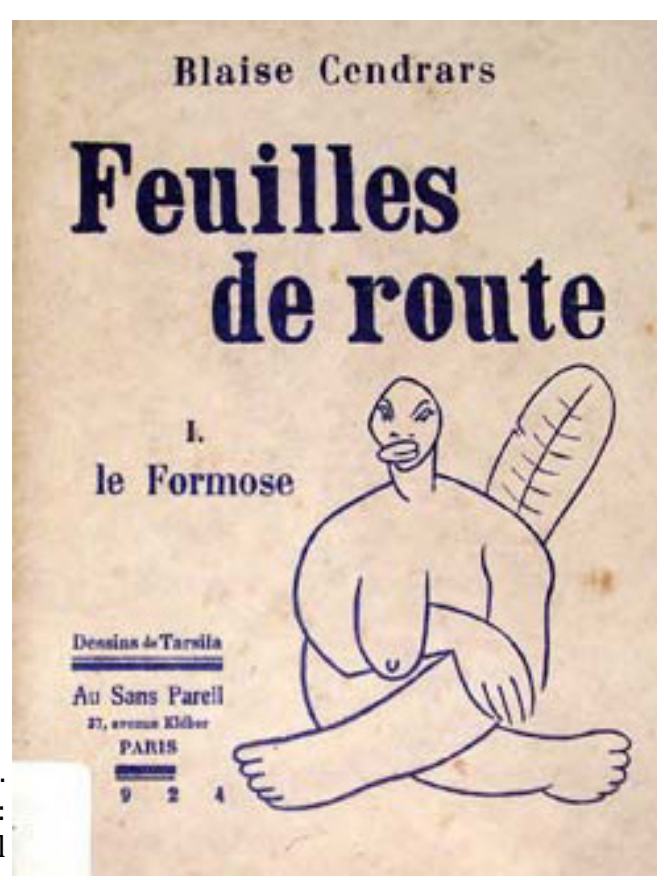


Os desenhos de "Feuilles de Route" são fruto da viagem de 1924 e da amizade, diálogo intelectual entre Tarsila do Amaral e Blaise Cendrars, aproximação que nasce de uma identificação e similaridade da experiência de cada um como estrangeiro na pátria do outro. Os desenhos foram realizados na França, em setembro do mesmo ano que ocorrera a viagem.

Esse desenho que consta na capa da publicação se refere à sua tela "A Negra", que já havia, no entanto sido pintada por Tarsila em 1923, durante suas aulas com Léger, em Paris.

Em termos da relação entre texto e desenho, os desenhos compõem o caderno como uma narrativa paralela à sequência de poemas, não tendo a pretensão de ilustrar literalmente o poema, que já tem, em Cendrars, uma visualidade própria, intrínseca à linguagem literária; os desenhos ilustram, então, um ideário, reforçam o sentido do que Cendrars criou.

Entende-se que os desenhos que ilustraram essa primeira edição do caderno de poemas de Cerndrars tiveream a intenção, enquanto escolha proposital, de apresentar Tarsila, seus croquis, como se um legitimasse o outro, dando coesão ao grupo, à proposta.

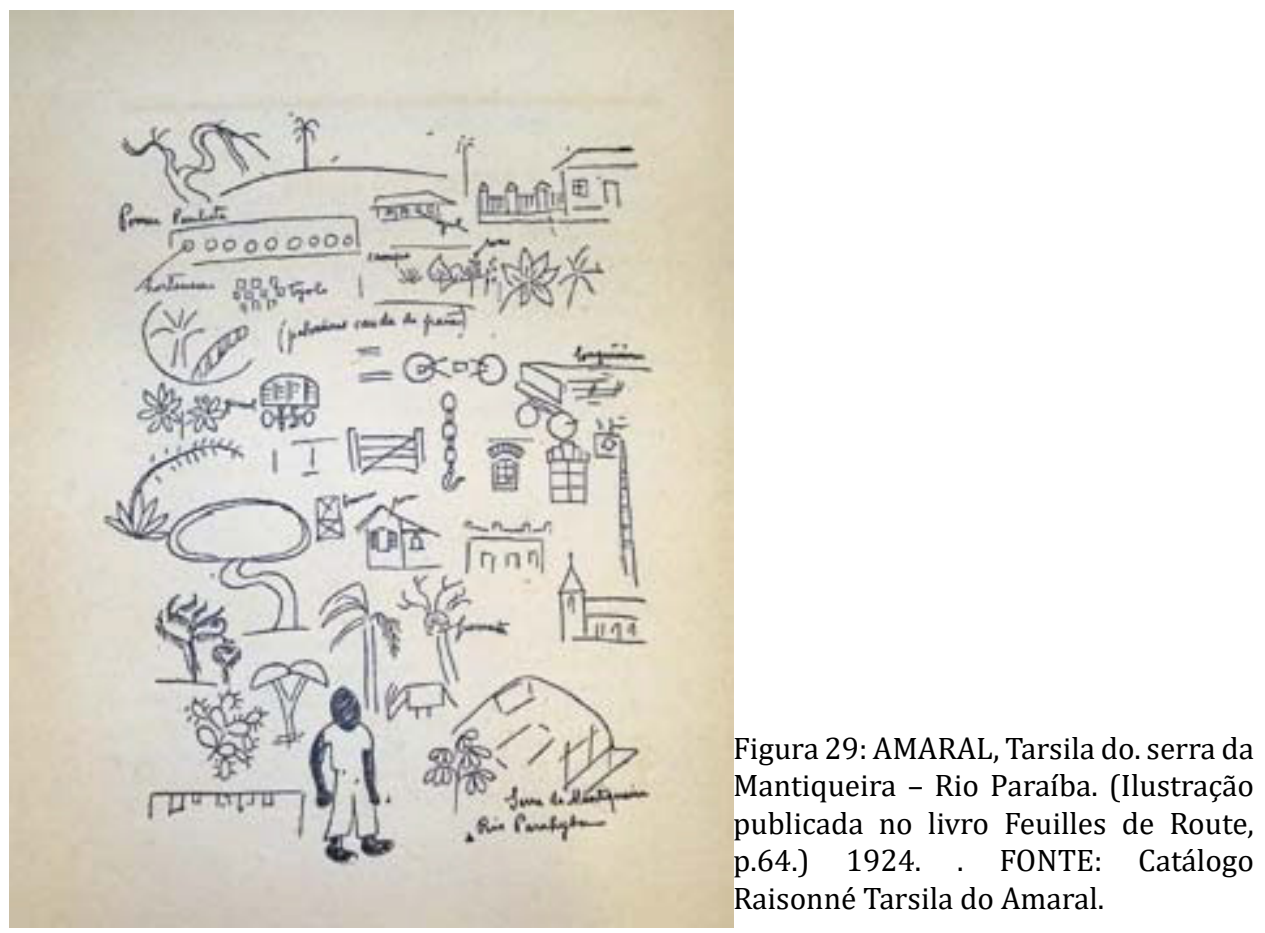

Nesse desenho, que podemos ler como um mapa de símbolos, onde estão presentes os elementos mais fortes graficamente e semanticamente. Nele podemos identificar elementos naturais, culturais, étnicos, tecnológicos.

Estão presentes a riqueza vegetal, com rosas, girassóis, cactos, árvores de vários tipos, palmeiras, coqueiros, chegando ao 
detalhe de apontar o parasita que vive em simbiose com a árvore. As palavras garantem aí o tipo de relação estabelecida, já que apenas a imagem não daria conta de esclarecê-la. Serve para orientar a interpretação dessa espécie de mapa. Uma única árvore representa um pomar, círculos são hortênsias, pontos num caule são rosas, uma forma arrendondada é a Serra da Mantiqueira. Essa indução se dá também no detalhe da indicação de cor para as construções: rosa, azul, branco. São instruções para a imaginação, já que o desenho é em preto e branco. Outras imagens fazem parte desse mapa brinquedo narrativo, em que o interlocutor é convidado a descobrir nuances de sentido e contar a própria história. (CARDOSO, 2006, p.90)

\section{_ desenhos da série Carnaval no Rio de Janeiro, em}

\section{4}

O Carnaval no Rio de Janeiro foi a primeira etapa da viagem de "redescoberta do Brasil" pelo grupo modernista, no referido ano de 1924. A festividade concentrava parte dos anseios dessa aventura, a de estar em imersão com eventos da cultura popular brasileira, além de apresentar a tradição que para o estrangeiro Cendrars, ainda era desconhecida.

Figura 30: AMARAL, Tarsila do. 1924.

Carnaval em Madureira (croqui) FONTE: Catálogo Raisonné Tarsila do

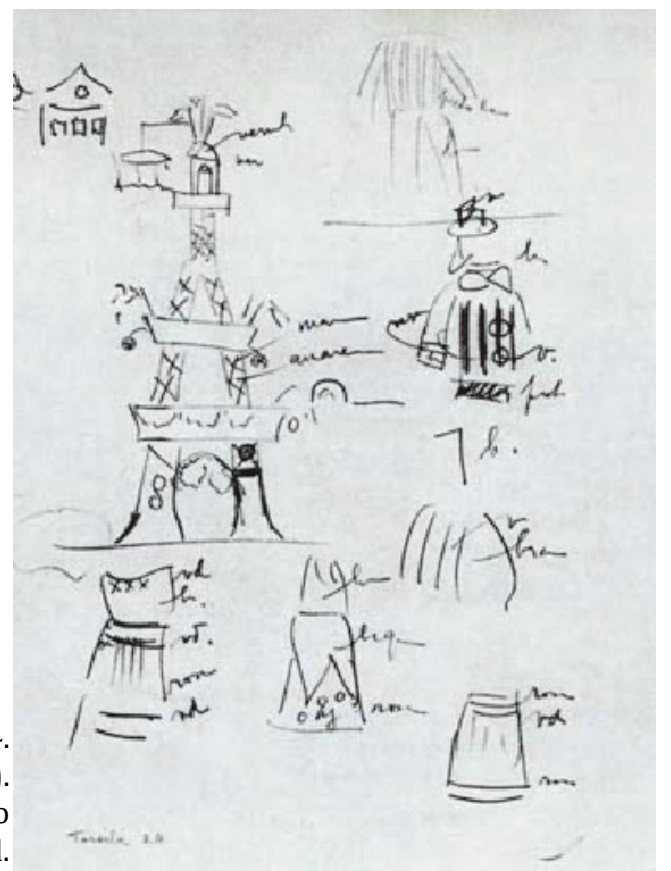


Na série de desenhos do Carnaval é que Tarsila faz alguns esboços que serão recuperados nas telas "Morro da Favela", pintada em 1924 e "Carnaval em Madureira", também da mesma data. Os estudos, ainda em formato de croqui já revelam muito da estrutura da tela.

0 croqui registrado em viagem que depois foi trabalhado na tela final de "Carnaval e m Madureira foi":

No momento de produção de croqui, a pintora elege como objeto principal uma torre alegórica apresentada por uma escola de samba, essa mesma torre é recuperada na versão final da tela. Aqui é interessante atentar para como os temas de quadros consagrados de Tarsila tiveram seu começo durante suas viagens, em registro de viagem. Isso demonstra como suas anotações de viagem já se pretendiam como possibilidade de projeto, como pesquisa, como investigação. Esses desenhos revelam uma característica de projeto, elaborados com uma finalidade imediata que irão adquirir uma condição de obra acabada posterior.

0 croqui do quadro tem um enfoque principal que é o elemento torre, e os secundários, que se apresentam como detalhamentos, anotações que serviriam para complementar o sentido, o contexto e curiosidades sobre o tema principal.

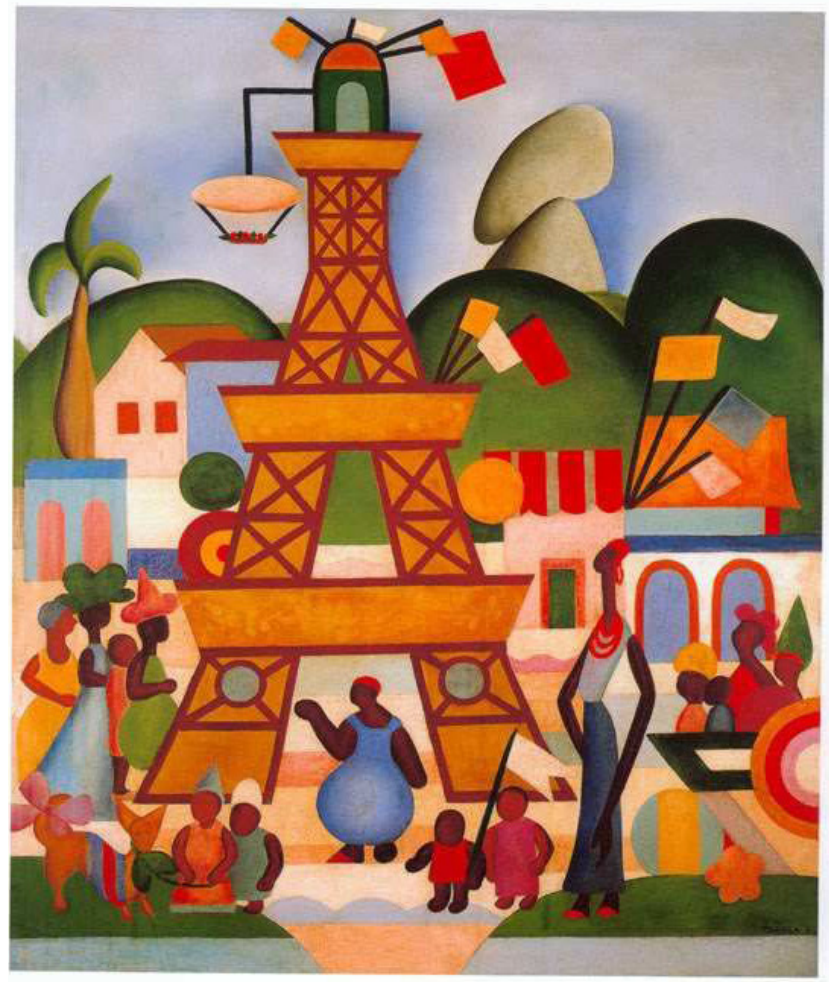

Figura 31: AMARAL, Tarsila do. 1924.

Carnaval em Madureira. FONTE: Catálogo Raisonné Tarsila do Amaral. 
Diferenças entre o croqui e a tela final são justificáveis, tanto pela técnica do uso da cor, quanto pela complementação da cena através de símbolos, elementos adicionados à composição, elementos aí que não estavam na cena observada, na realidade física que fora anotada "in loco", mas na imaginação da artista.

\section{_desenhos da série viagem a Minas Gerais, em 1924}

Essa série é a que concentra o maior número de desenhos de registro durante o período da viagem. São cerca de 120 desenhos, entre perspectivas urbanas, rurais, silhuetas, detalhes arquitetônicos e de decoração, dos quais, recortamos 31 deles para a leitura.

Os desenhos que foram elaborados durante o período mineiro da viagem de 1924 com o grupo modernista são predominantemente de cenas urbanas, mesclando elementos naturais de fundo, são muitos desenhos, e cada um desses, que selecionam uma cidade ou uma vista dela como ponto de partida, captam a fisionomia da cidade como um todo, e todos conservam essa preocupação, de dispor num mesmo campo visual as informações essências que identificam aquela cidade como tal.

Dessa série temos desenhos de Mariana, Congonhas, São João del Rei, Tiradentes, Ouro Preto, Sabará e Belo Horizonte. Pelos desenhos de cidade, conseguimos captar a unidade presente em todas essas formações urbanas, conseguimos identificar um período, um contexto, um padrão arquitetônico. 0 desenho de Tarsila é traçado de forma simples, sintética, na qual só o essencial é delineado, só o necessário para a compreensão dessa fisionomia.

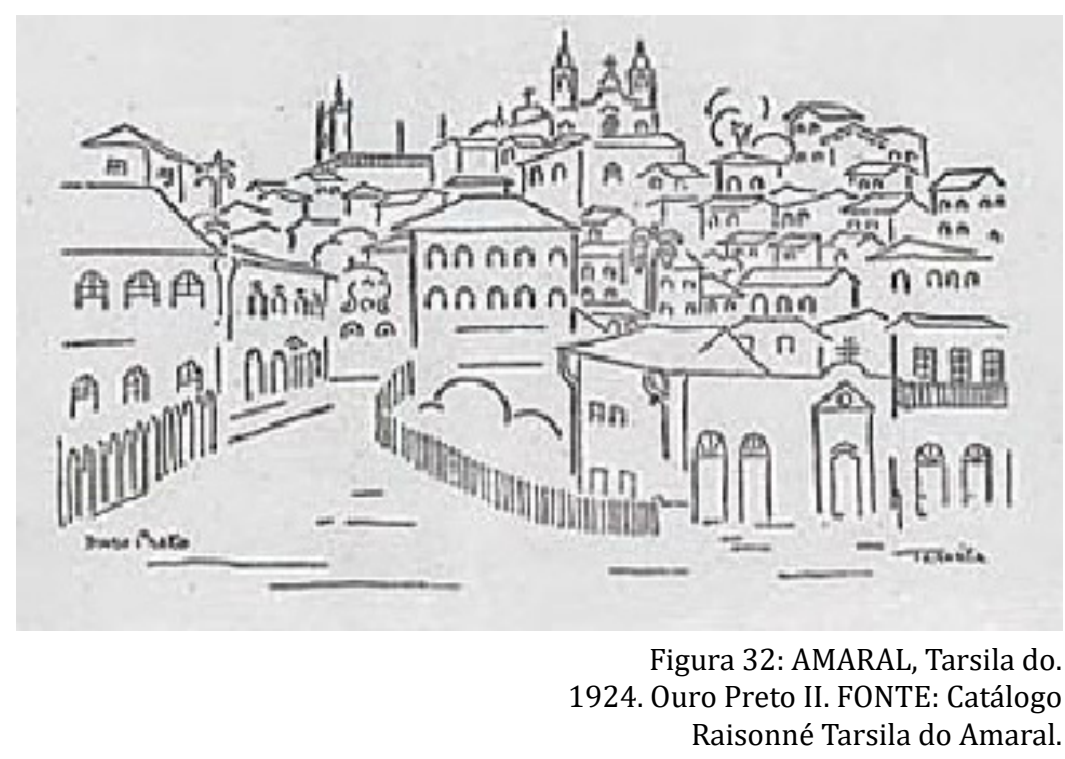


Essa série, por se concentrar em desenhos de perspectivas urbanas, acaba por representar muitos deles de maneira parecida, o traço sintético que se reporta por exemplo à ornamentação de uma igreja ou ao delineado dos morros, é muito parecido entre desenhos da mesma série.

\section{_ campo visual}

Foram escolhidos os desenhos em traço sobre papel, e observados, primeiramente, série a série e folha por folha, a disposição de desenhos, conjuntos de detalhes.

Quanto ao campo visual, foram identificados três padrões: o primeiro é definido por um quadro imaginário, em que o desenho se concentra, com algumas variações de alinhamento, no centro da folha. As folhas com esse padrão nos mostram desenhos de uma cena só, ou as vezes um grande detalhe. São as vezes cenas de importância notável, que mereceu uma folha inteira para a representação daquela paisagem, anotação ou ideia.

O segundo padrão é a disposição de dois desenhos ou conjunto de desenhos, cada um com uma importância, distinção, caracterizando uma linha divisória na folha.

Nesse padrão, por mais que os desenhos sejam distintos, há uma afinidade temática entre os desenhos na mesma folha, ainda que em dois campos.

0 terceiro padrão ficou caracterizado pela identificação de mais de dois conjuntos de desenhos na folha, cada um com sua importância, tamanho, tema. Nesse padrão, é comum é a presença de desenhos de mais destaque e outros secundários, por exemplo, blocos secundários de detalhamentos, de maneira que, no conjunto da folha, um desenho complementa o sentido do outro.

No sentido da viagem, essa disposição na folha é adequada à dinâmica da anotação em viagem, em que se observa uma cena, e o sentido desta, é completado a partir de anotações dos detalhes em desenho e até mesmo em anotações de texto.

Essa disposição nos exemplifica a questão do agrupamento de informações possíveis sobre o entendimento de uma cena, prática que é muito compatível ao formato de croqui.

Depois de ler todos os desenhos de cada conjunto a partir desses padrões de campo visual na folha, foram elaborados diagramas comparativos de cada série. 

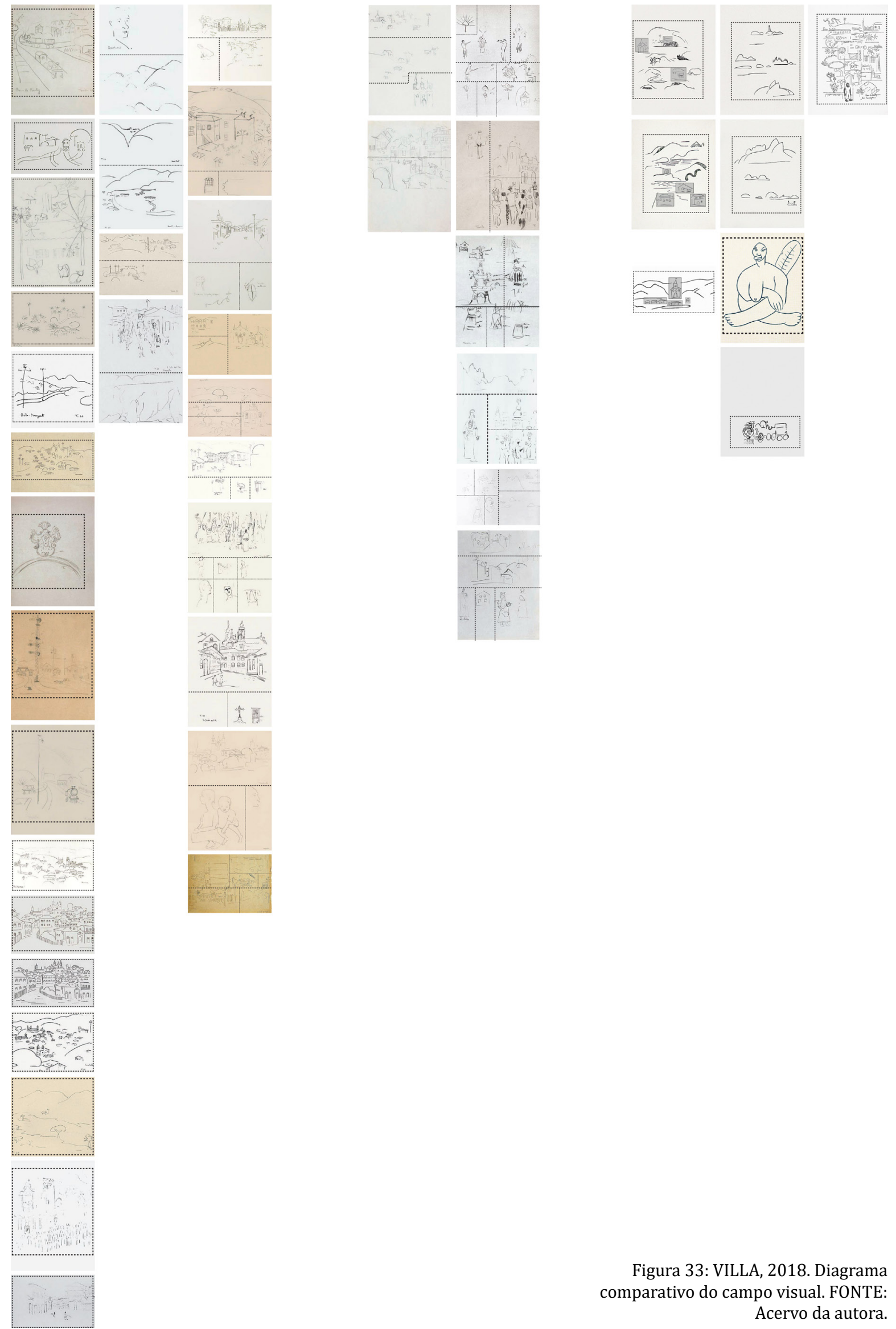

बif

Figura 33: VILLA, 2018. Diagrama comparativo do campo visual. FONTE: Acervo da autora. 


\section{temático}

O segundo critério empregado na leitura das imagens foi o temático, da mesma forma que no primeiro, os desenhos foram lidos a partir das séries.

Os temas foram classificados em desenhos de paisagem natural, cena urbana/arquitetônica e objetos/perfis/silhuetas.

Dentro dessa classificação, observamos que em algumas folhas, essa divisão é tênue, sendo possível identificar mais de um tema em uma mesma folha, em proporções variáveis, essas proporções se observam na disposição em diagrama.

Os temas recorrentes nos desenhos de duas das três séries de desenhos são as paisagens urbanas, elementos arquitetônicos, manifestações culturais populares, as duas séries com mais desenhos dessa temática são as duas produzidas em viagem: A série de desenhos do Carnaval no Rio de Janeiro e a série de desenhos de Minas. Esses são desenhos mais despretensiosos, não almejavam ilustrar Minas, mas captar as impressões sobre o lugar.

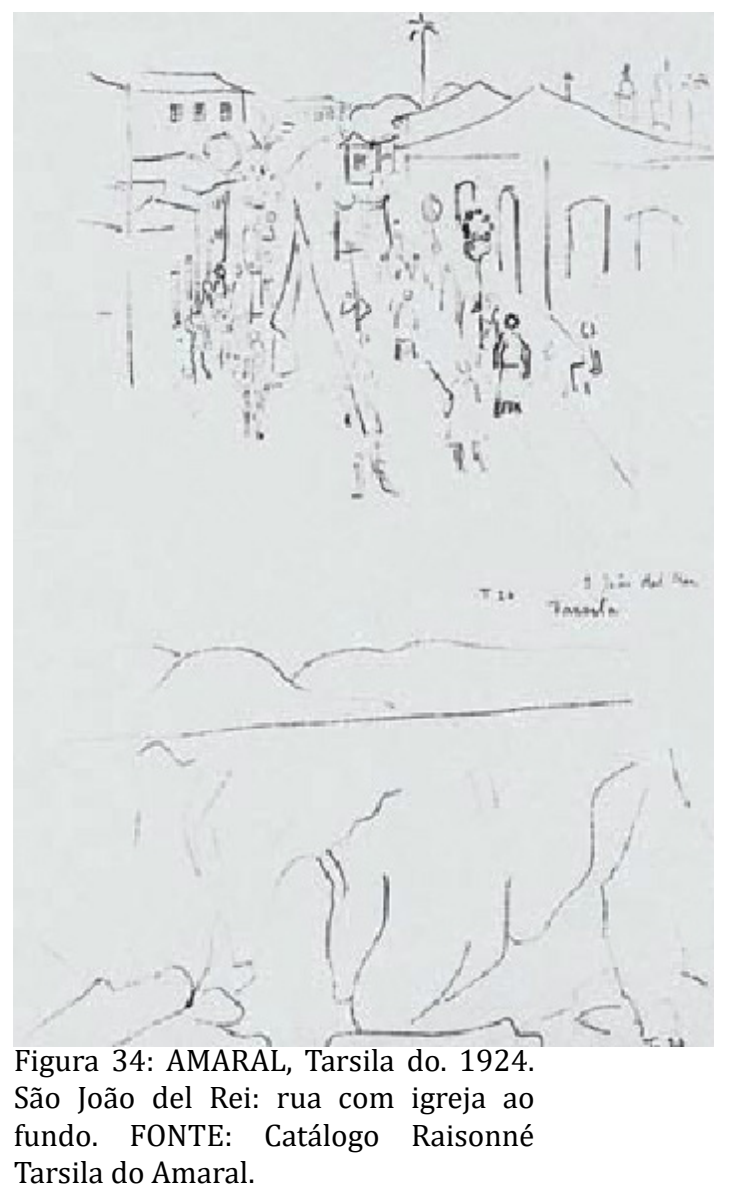


152
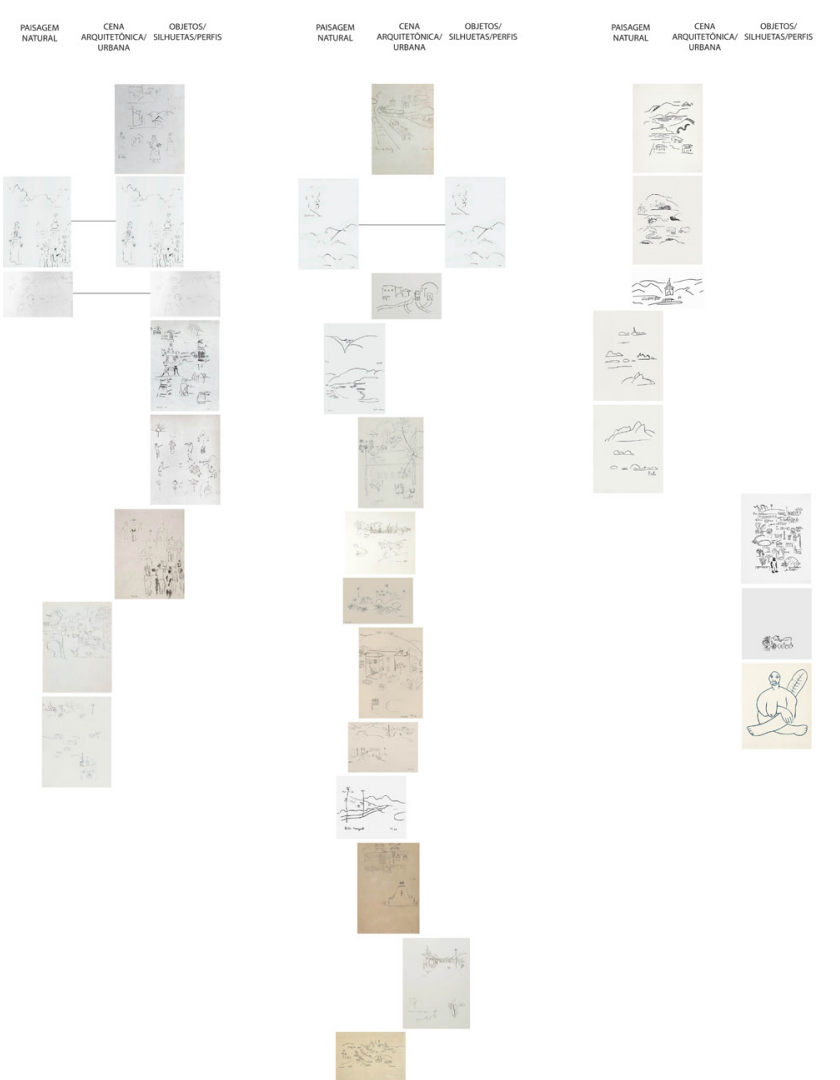

Figura 35: VILLA, 2018. Diagrama comparativo temático. FONTE: Acervo da autora 


\section{_ elementos de composição}

A partir da análise dos critérios um e dois, descritos no texto acima, percebemos mais do que recorrências temáticas, a presença de seis elementos básicos, com os quais Tarsila compôs seus desenhos mais sintéticos e expressivos.

Os elementos identificados são: 0 Poste, a Silhueta, o Morro, a Casa, a Igreja, a Ferrovia.

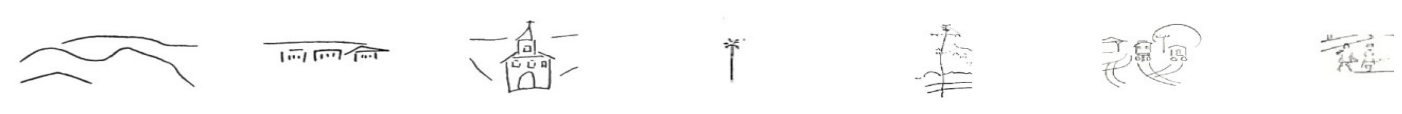

Figura 36: VILLA, 2018. Diagrama de elementos de composição com croquis de Tarsila do Amaral. FONTE: Acervo da autora.

A tela representativa por excelência desse conceito de composição de elementos é "E.F.C.B.", Estrada de Ferro Central do Brasil, tela pintada por Tarsila para participar da exposição-conferência sobre o modernismo de Blaise Cendrars no Brasil, que aconteceu em São Paulo em junho de 1924.

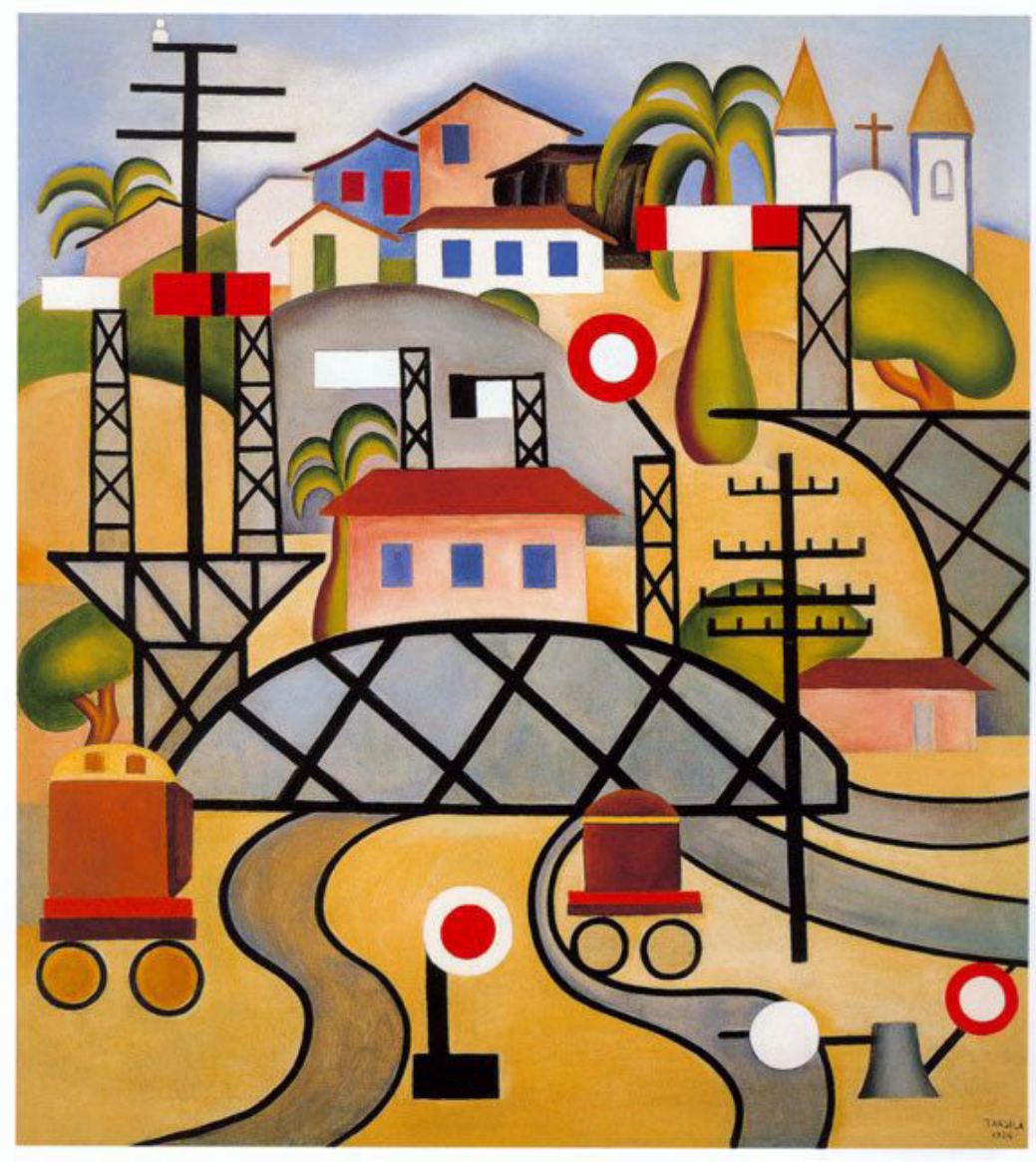

Figura 37: AMARAL, Tarsila do. 1924. E.F.B.C. FONTE: Catálogo Raisonné Tarsila do Amaral. 
Nessa tela, a pintora faz uso de muitos dos identificados elementos de composição, a fachada de casa em planos, os elementos naturais com coqueiro, vegetação cactácea, árvore de copas diversas, relevos arredondados, silhuetas de personagens, animais. Outra característica já presente nos croquis e que foi transportado para as tela é a noção de perspectiva alcançada pelo uso de planos mais próximos e mais distantes do observador.

"Morro de Favela" é não só a justaposição de elementos formais, mas é um conjunto de significado, é a manifestação da composição semântica, temática, de uma ideia.

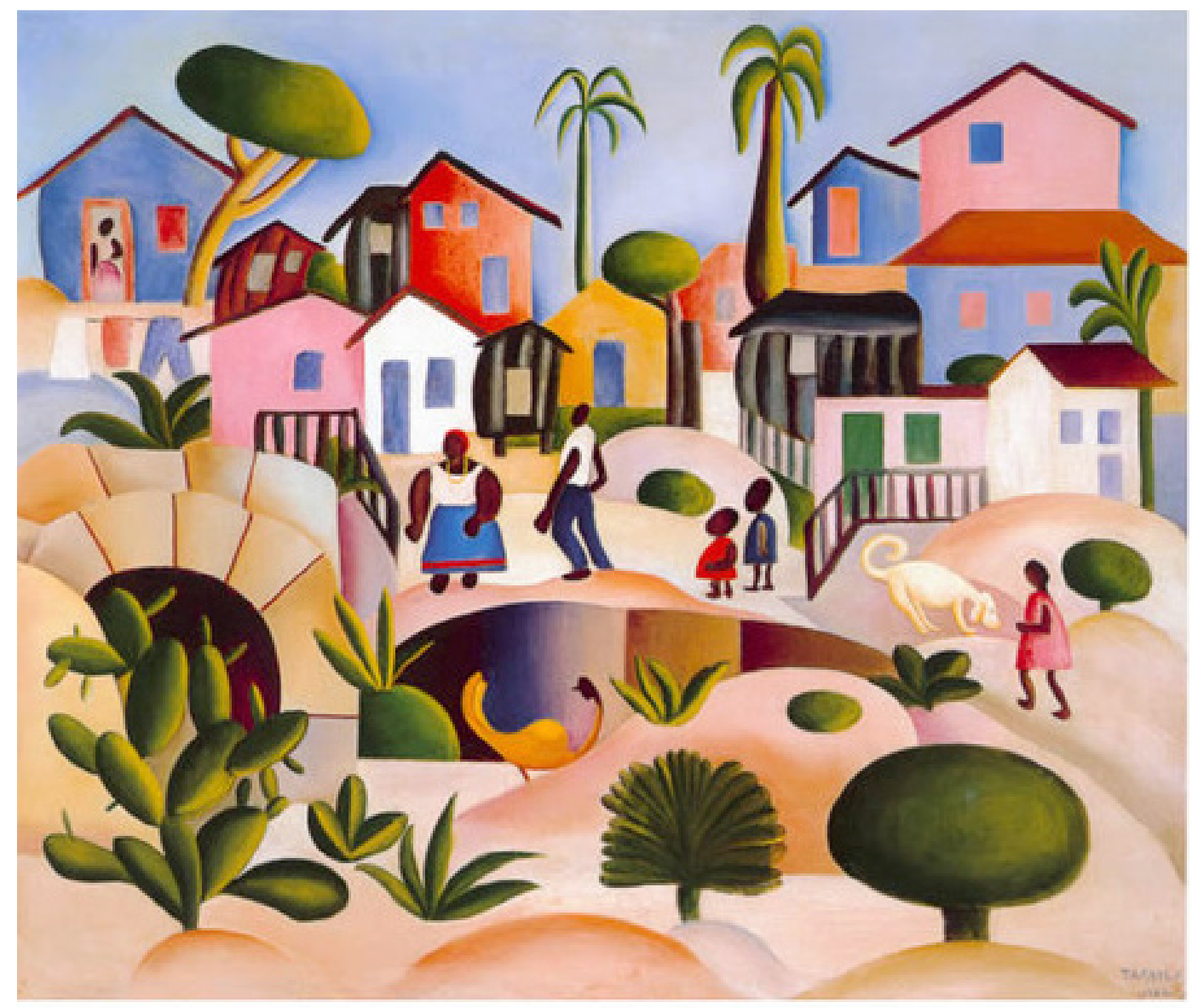

Figura 38: AMARAL, Tarsila do. 1924. Morro de Favela. FONTE: Catálogo Raisonné Tarsila do Amaral.

A partir da leitura dos desenhos das três séries apresentadas, foram identificados dois tipos de desenho em que os desenhos se encaixam: 0 primeiro se refere ao desenho de observação, que tem em muitos momentos de seu campo visual, anotações, é um desenho mais descritivo, fiel à alguma realidade observada pela artista viajante; o segundo tipo é o que denominamos desenho de composição, esses são desenhos expressivos, sintéticos, nos quais a perspectiva é compreendida em planos sucessivos de profundidade distintas. 

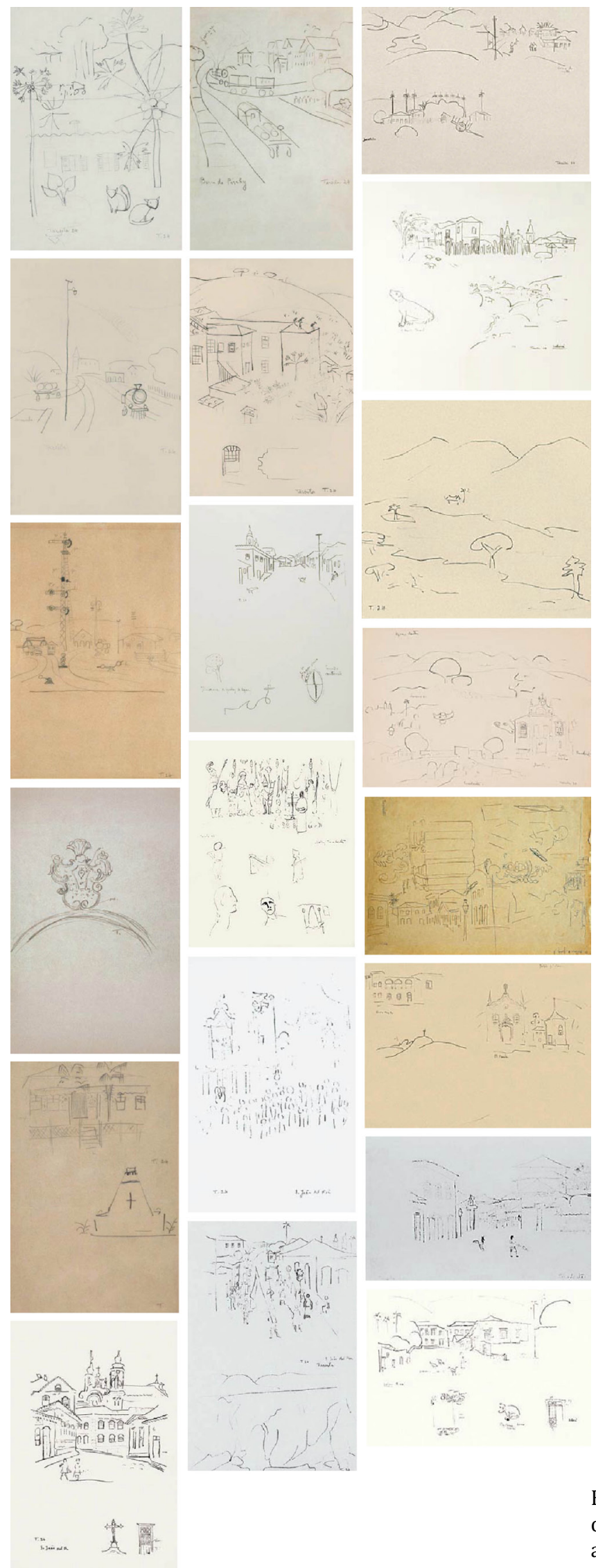

Figura 39: VILLA, 2018. Diagrama observação Minas. FONTE: Acervo da autora. 
Figura 40: VILLA, 2018. Diagrama composição Minas. FONTE: Acervo da autora.

Figura 41: VILLA, 2018. Diagrama observação Carnaval no Rio de Janeiro. FONTE: Acervo da autora.
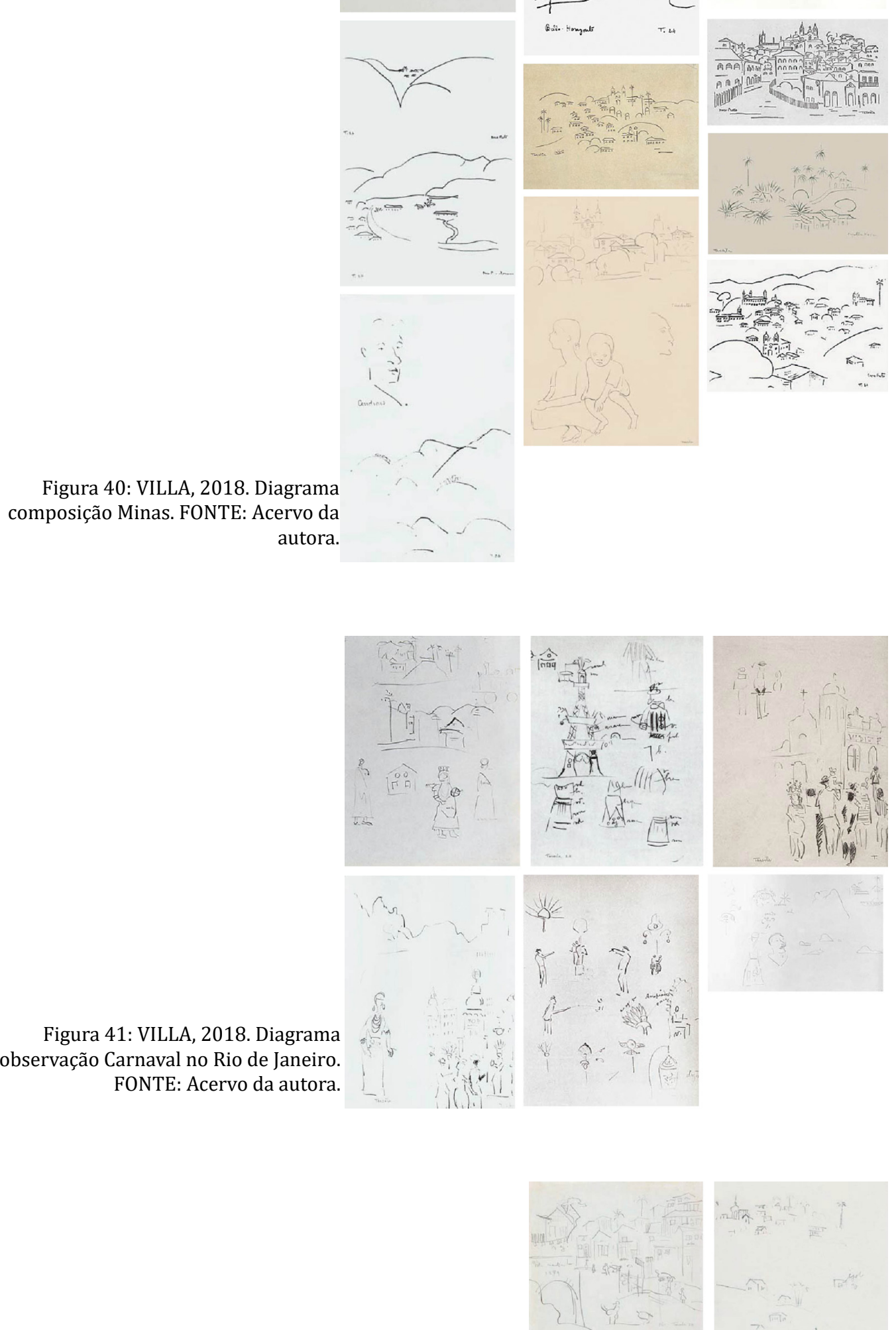

Figura 42: VILLA, 2018. Diagrama

composição Carnaval no Rio de Janeiro. FONTE: Acervo da autora.

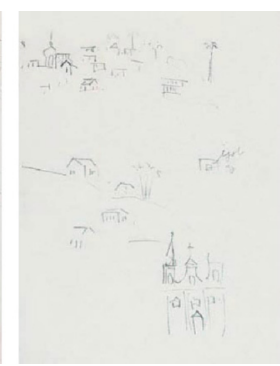


Figura 43: VILLA, 2018. Desenho observação Ilustrações. FONTE: Acervo da autora.
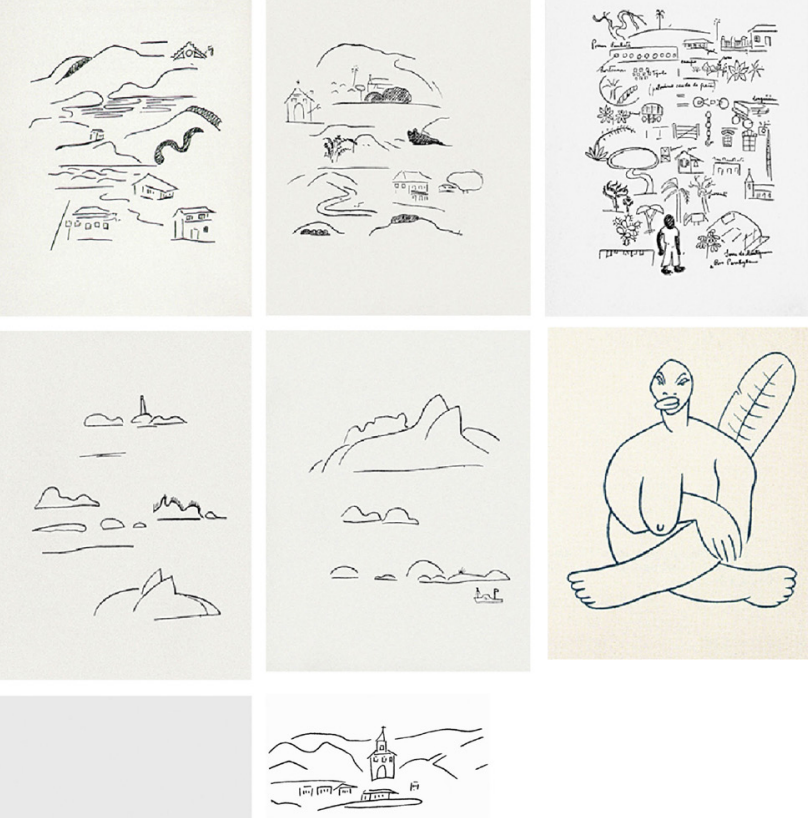

Figura 44: VILLA, 2018. Diagrama composição Ilustrações. FONTE: Acervo da autora.

Essa dimensão compositiva dos croquis de Tarsila do segundo tipo é interpretada dentro da chave cubista:

Reduzindo tudo a poucos e simples elementos básicos, estabelecendo novas e imprevistas relações de vizinhança na sintagmática do quadro, Tarsila codificava em chave cubista a nossa paisagem ambiental e humana, ao mesmo tempo que redescobria o Brasil nessa releitura que fazia, em modo seletivo e crítico (sem por isso deixar de ser amoroso e lírico), das estruturas essenciais de uma visualidade que a rodeava desde a infância fazendeira. (AMARAL, 1975)

Os desenhos do segundo tipo são a chave da criação artística de Tarsila, se de alguma forma ela aprende e começa a absorver a realidade com o desenho de observação, no segundo tipo, ela desenha uma ideia pré-concebida em sua mente, é o retrato de uma ideia que parede ter estado em gestação na viagem, 
e são esses os desenhos mais próximos à linguagem desenvolvida nas telas.

Ouro Preto II, croqui da série de Minas Gerais, contém quase todos os elementos compositivos, e é a expressão do tipo de desenho compositivo, de traços precisos, essenciais, com a profundidade definida em planos de desenhos sem o uso obrigatório de ponto de fuga.

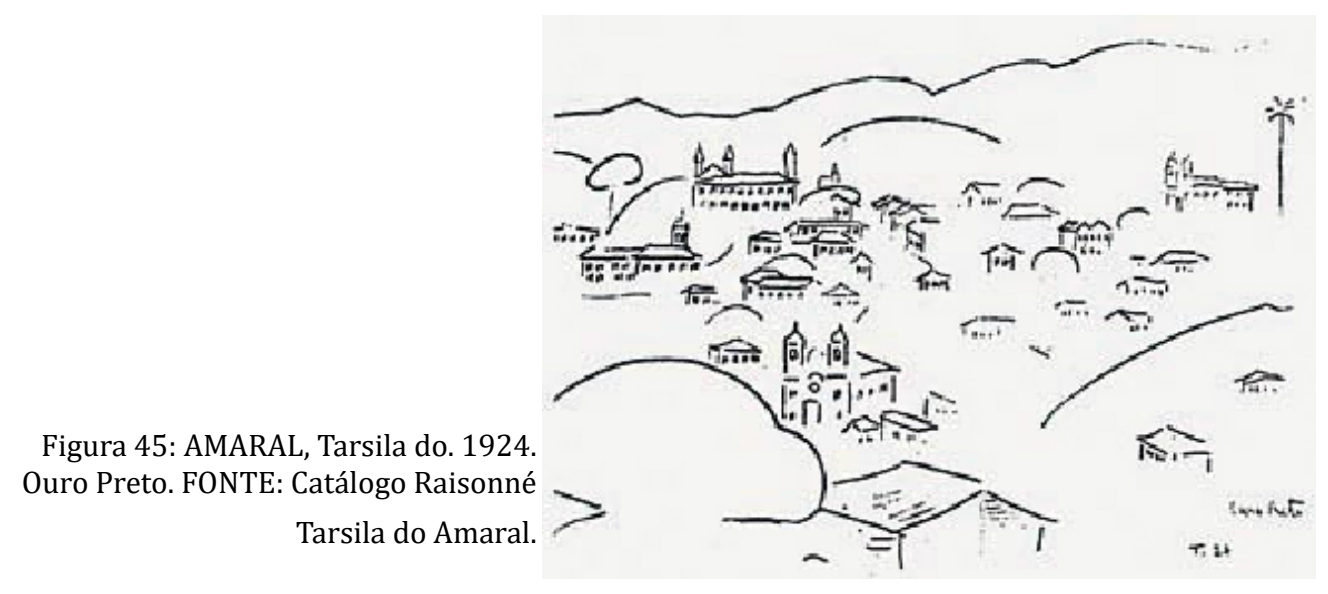

1.

Lucio, brasileiro, nascido na França durante o período no qual seu pai viajava em missão oficial do governo brasileiro, vem no mesmo de1910 para o Rio Janeiro, onde vive a maior parte da sua vida. No período entre 1910 e 1916, muda-se para a Europa com a família. Nesse tempo Lucio estuda na Suíça e Inglaterra, e voltando para o Rio de Janeiro, em 1917, já ingressa na Escola Nacional de Belas Artes.

O começo da sua carreira foi marcado pelo predomínio da arquitetura eclética da época, referencia que é também influencia de sua formação. Lucio foi um dos arquitetos com mais prestígio dentro do movimento neocolonial, marcando uma fase de sua produção arquitetônica e teórica.

Foi a partir de 1924, na famosa viagem à Diamantina que o arquitetoestudante tomou contato com a cidade do período colonial e a pureza e da simplicidade da arquitetura civil escondida no interior do país.

Um rompimento com o movimento neocolonial de que participou iria acontecer mais tarde, por volta de 1930, depois de pesquisas, viagens, confrontos e reflexões sobre a arquitetura tradicional de Minas e os preceitos do movimento moderno, como uma síntese.

0 fomento à nascente arquitetura moderna brasileira tem relação com a atuação profissional e de ensino, principalmente com o episódio de 1930, 
de reforma do ensino na ENBA, e com o projeto para o MESP (Ministério de Educação e Saúde) para o Rio de Janeiro, em 1936, com a colaboração do jovem Oscar Niemeyer e clara influência de Le Corbusier.

Outro momento importante da atuação profissional e política de Lucio Costa é o ingresso dele em 1937 no SPHAN (Serviço do Patrimônio Histórico e Artístico Nacional), onde permaneceu até 1972.

A trajetória intelectual de Lucio foi muito afetada pelas investigações que ele fez fisicamente, em seus deslocamentos pelas regiões pouco estudadas do Brasil no referido período e também suas próximas viagens, que acreditamos ter relação com essa iniciação que o arquiteto viveu ao percorrer Minas Gerais em 1924.

\section{_a viagem a Diamantina no percurso formativo de} Lucio Costa

Diferentemente dos outros quatro personagens-viajantes desse estudo, Lucio não viaja com o grupo de modernistas, estava, então, em um outro ponto de sua formação, bem mais jovem que os outros três em questão, em 1924, Lucio era um jovem estudante de 23 anos.

Estudando arquitetura na ENBA realiza nesse mesmo período, uma viagem de estudos financiada por José Mariano Filho ${ }^{28}$ através da Sociedade Brasileira de Belas Artes (SBBA), forte influência dentro do movimento neocolonial. Nessa viagem visitou brevemente Sabará, Ouro Preto e Mariana e se demorou mais tempo em Diamantina.

A procura por uma autenticidade brasileira na arquitetura teve início no desconforto que ele sentiu em relação aos rumos do movimento neocolonial e a afeição com a "pureza", "simplicidade" que reconheceu na arquitetura de Minas na ocasião dessa viagem em 1924, que não era o objetivo inicial da viagem, mas aconteceu no âmbito do imprevisto, do impacto das impressões que o viajante experenciou no local.

O objetivo inicial da viagem, organizada pela Escola de Belas Artes era o de levantar material sobre a arquitetura colonial em Minas Gerais, a fim de complementar as pesquisas de José Mariano Filho, em sua importância como

28 José Mariano Filho, médico e historiador de arte pernambucano, teve atuação influente na ENBA na defesa do movimento neocolonial no Rio de Janeiro na época da viagem de Lucio Costa a Minas Gerais (Diamantina) em 1924. 
o mentor do movimento neocolonial no Rio de Janeiro ${ }^{29}$. Ainda patrocinou, da mesma forma, a viagem de Nestor de Figueredo a Ouro Preto e de Nereu Sampaio a Congonhas do Campo, também estudantes.

É durante essa viagem que Lucio, em Diamantina produz as pranchas de desenhos que recortamos para essa leitura. Além dos desenhos nas pranchas selecionadas, Lucio também escreveu textos sobre a sua experiência de viagem, que foram posteriormente reunidos em seu livro autobiográfico "Registro de uma vivência".

Destacamos alguns desses textos, tais como: "Diamantina", escrito em 1924, logo após a viagem, "A alma dos nossos lares", escrito em março do mesmo ano de 1924 e "Considerações sobre nosso gosto", escrito três meses depois desse último. São todos textos que revelam, em frases carregadas de um forte sentimentalismo, e exprimem o impacto e o sentido de "epifania" que essa viagem de estudante teve em sua formação.

O sentido de "Epifania" é aqui entendido como uma súbita compreensão de algumas questões advindas do contato direto e revelador com a arquitetura e a construção de "outros tempos" durante sua viagem.

Essa citação de Lucio, de seu texto "Considerações sobre nosso gosto", fala sobre essa revelação, surpresa com a qual é acometido ao se deparar com a arquitetura colonial mineira:

Figura 46: COSTA, Lucio. fotografia de Lucio Costa e grupo em viagem em 1924. FONTE: Acervo: (Lucio Costa) Instituto Antônio Carlos Jobim.

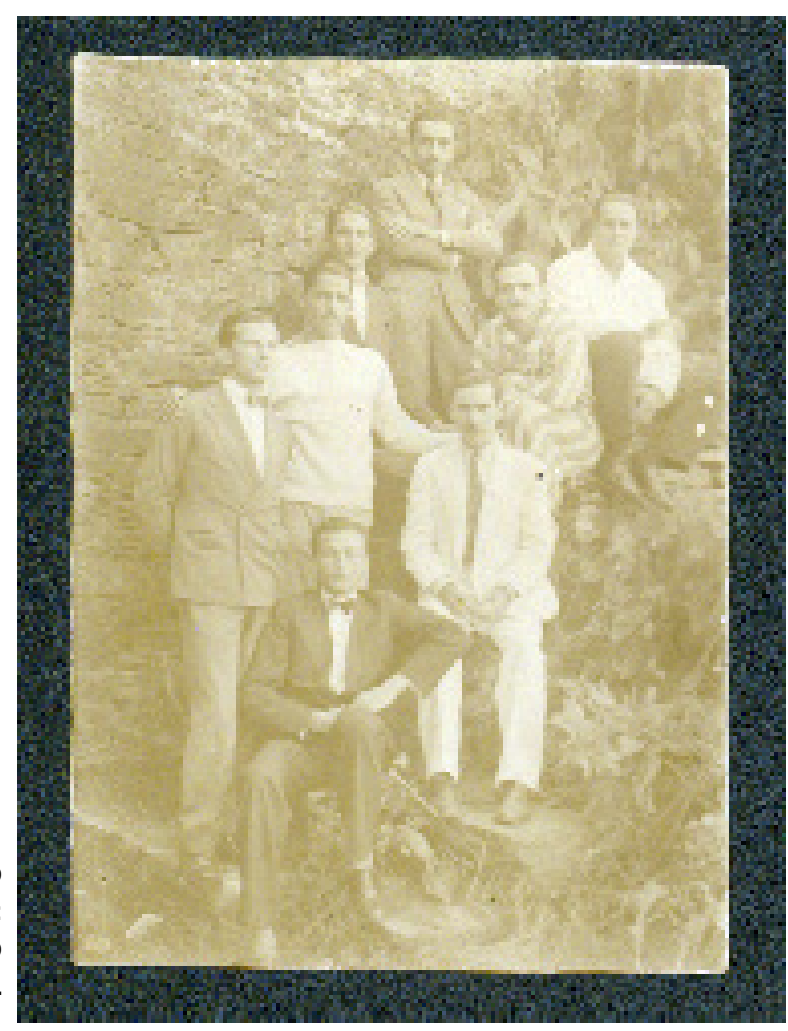


De minha viagem a Diamantina, [...], tentarei apenas dar as impressões gerais que tive e as idéias que elas me sugeriram, sem entrar em detalhes técnicos que somente aos arquitetos podem interessar. Confesso-lhe que foram muitas as surpresas. Encontrei um estímulo inteiramente diverso: desse colonial de estufa, colonial de laboratório, que nesses últimos anos surgiu e ao qual, infelizmente, já se está habituando o povo, a ponto de classificar o verdadeiro colonial de inovação. Aolado das construções barrocas, jesuíticas, arquitetura francamente religiosa, há a arquitetura civil de um aspecto muito característico e de particular interesse. [...] Apreciando as construções de outros tempos, dos tempos em que se construía sem a preocupação de chamar a atenção pela extravagância das formas e pelo alarde das cores, senti em toda a sua plenitude o disparate de certos edifícios, alguns muito belos, mas de um estilo que absolutamente não se adapta ao nosso clima. (COSTA, 1995)

Da surpresa e do conceito de "aclimatado", o caráter que o barroco mineiro brasileiro teve em relação às suas outras manifestações anteriores, muito "estilísticas", por exemplo. E é nessa caraterística que reside o interesse de Lucio Costa e outros intelectuais modernistas que visitam as cidades mineiras.

Há um destaque para essa narrativa do "impacto", os termos usados no texto para descrever essa sensação são: "surpresa", "revelação":

Lá chegando, cai em cheio no passado, no seu sentido mais despojado, mais puro; um passado que era novo em folha para mim. Foi uma revelação: casas, igrejas, pousada dos tropeiros [...] Depois a fachada da casa de Chica da Silva, a famosa amante do contratador, resguardada por extenso muxarabi, e, defronte, a capela do Carmo, construída para ela, cuja chave o sacristão Zacarias - com sua bonita mulher de pés no chão - me confiara para que ficasse à vontade, na solidão da igreja fechada, pintando uma aquarela do seu lindíssimo interior. (COSTA, 1995)

Os relatos foram escritos no intuito de descrever essa revelação, em primeira pessoa, em tom biográfico, narrador de uma experiência própria, das sensações.

Podemos pensar na hipótese de que a "conversão ao moderno" na arquitetura em Lucio Costa, que (segundo diversos historiadores) deu por volta de 1930, teve início efetivamente já a partir de 1924, logo após a viagem a qual nos referimos. 
Através de nossa observação dos poucos registros organizados sobre esse período, podemos encontrar um elo entre esses dois momentos, o da viagem em si, e aquele da adesão mais direta aos pressupostos da arquitetura moderna.

Mesmo não existindo, nesses textos, um elogio direto aos preceitos do moderno, a percepção desse elo se dá de forma sutil, correlacionando as características dos desenhos elaborados com o discurso desenvolvido pelo viajante em seus textos, na intenção de pesquisa dos elementos de arquitetura que ele fez, de forma cuidadosa, curiosa, aliada aos textos "autobiográficos", relatos do período logo após a viagem.

\section{_as pranchas e as aquarelas, o tom do registro}

Os registros selecionados para essa leitura foram seis pranchas e 2 desenhos, que Lucio trouxe de sua viagem a Diamantina, de 1924. As seis pranchas, são repletas de desenhos de levantamento, com rigoroso traço técnico, preciso, com informações métricas, anotadas através de cotas e escalas detalhadas. Selecionamos também outros dois desenhos, aí de teor ilustrativo, duas aquarelas bem acabadas, desenhos de apresentação.

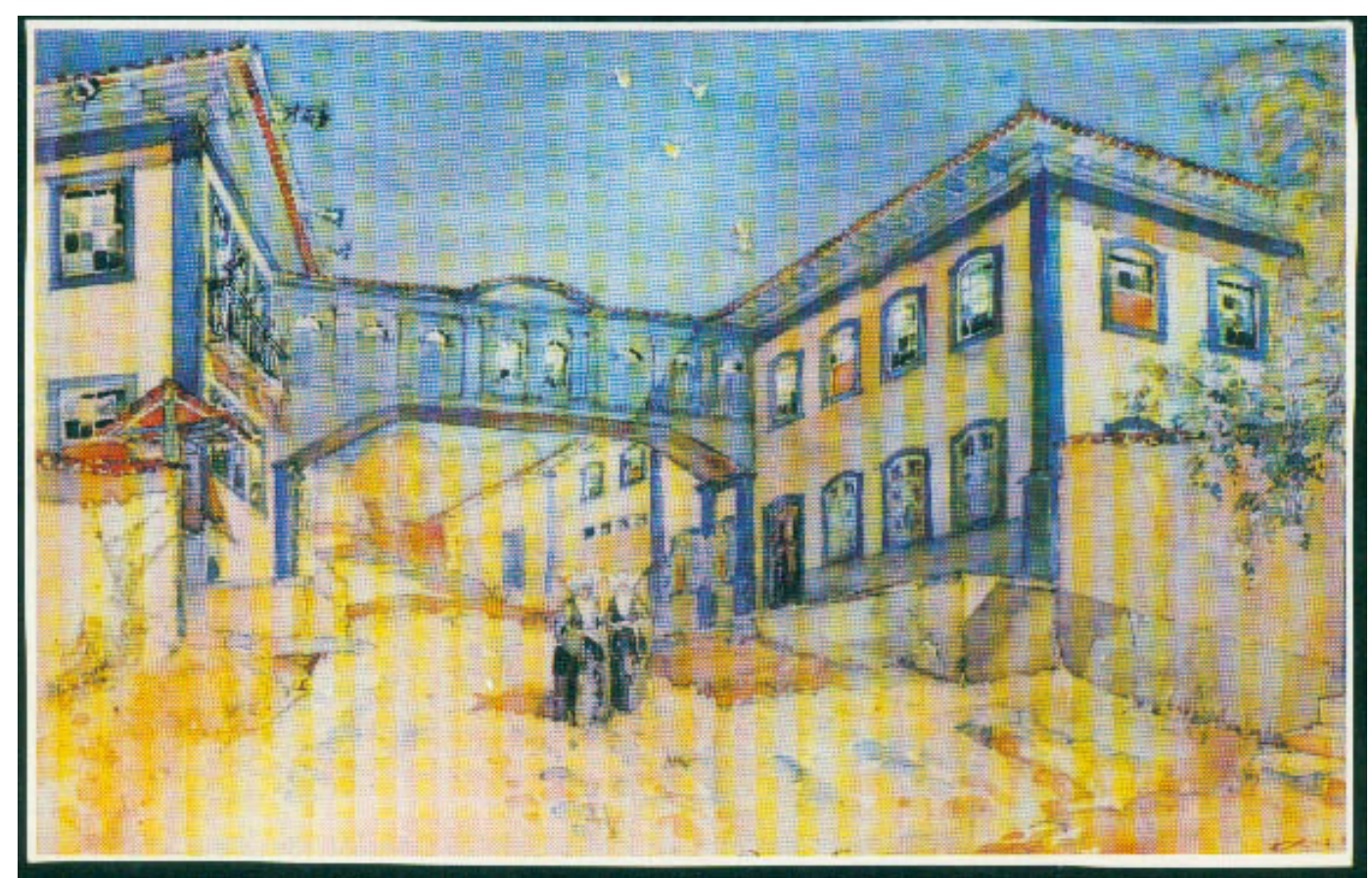

Figura 47: COSTA, Lucio. 1924 aquarela passadiço de Diamantina. FONTE: Acervo: (Lucio Costa) Instituto Antônio Carlos Jobim. 


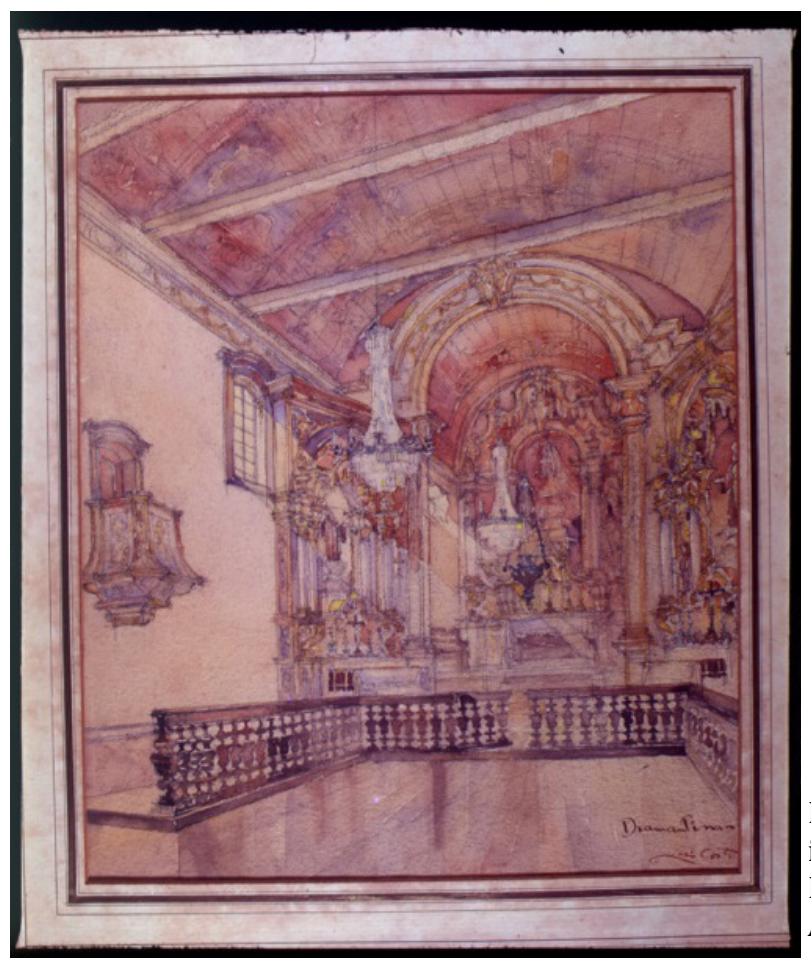

Figura 48: COSTA, Lucio. 1924. aquarela interna de Igreja em Diamantina. FONTE: Acervo: (Lucio Costa) Instituto Antônio Carlos Jobim.

Entendendo as duas aquarelas enquanto desenhos de apresentação, podemos interpretá-las dentro da chave da tradição das viagens de estudos, na matriz dos "grand tours", ou até mesmo no modelo de representação de Ruskin. Os desenhos se pretendiam belos, cheios de detalhes. Neles o objetivo era captar as minúcias dos detalhes dos elementos decorativos.

As seis pranchas também podem ser lidas a partir dessas referências, na medida em que o teor dos registros nelas contidos era o documental, daí os desenhos precisos, de qualidade técnica.

Todos os desenhos vêm acompanhados de anotações de títulos, descrevendo o local, o tipo de seção. Foram organizados em sua disposição na prancha em dois tipos: desenho principal em vista e seções, ou no segundo tipo, estudos de várias possibilidades, tipos, dispostos sem hierarquia na prancha.

$\mathrm{Na}$ leitura temática, todas as pranchas tratam do desenho de partes, elementos recortados do conjunto da arquitetura colonial brasileira produzida em Minas Gerais, mas, dentro desse mesmo recorte, identificamos dois grupos: o primeiro que são pranchas de predominância de elementos decorativos, e o segundo, em que há uma preocupação maior com o entendimento dos elementos construtivos da obra. 

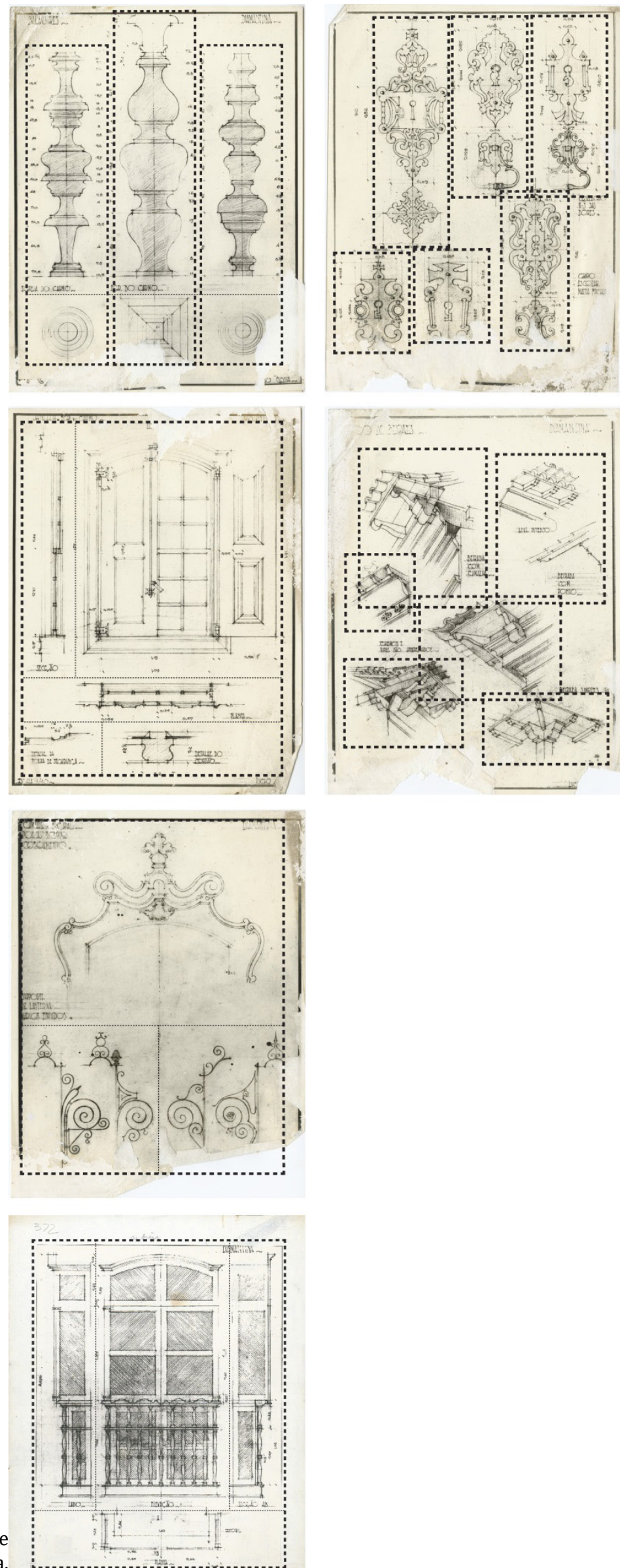

Figura 49: VILLA, 2018. Diagrama d organização dos desenhos na prancha. FONTE: Acervo da autora. 

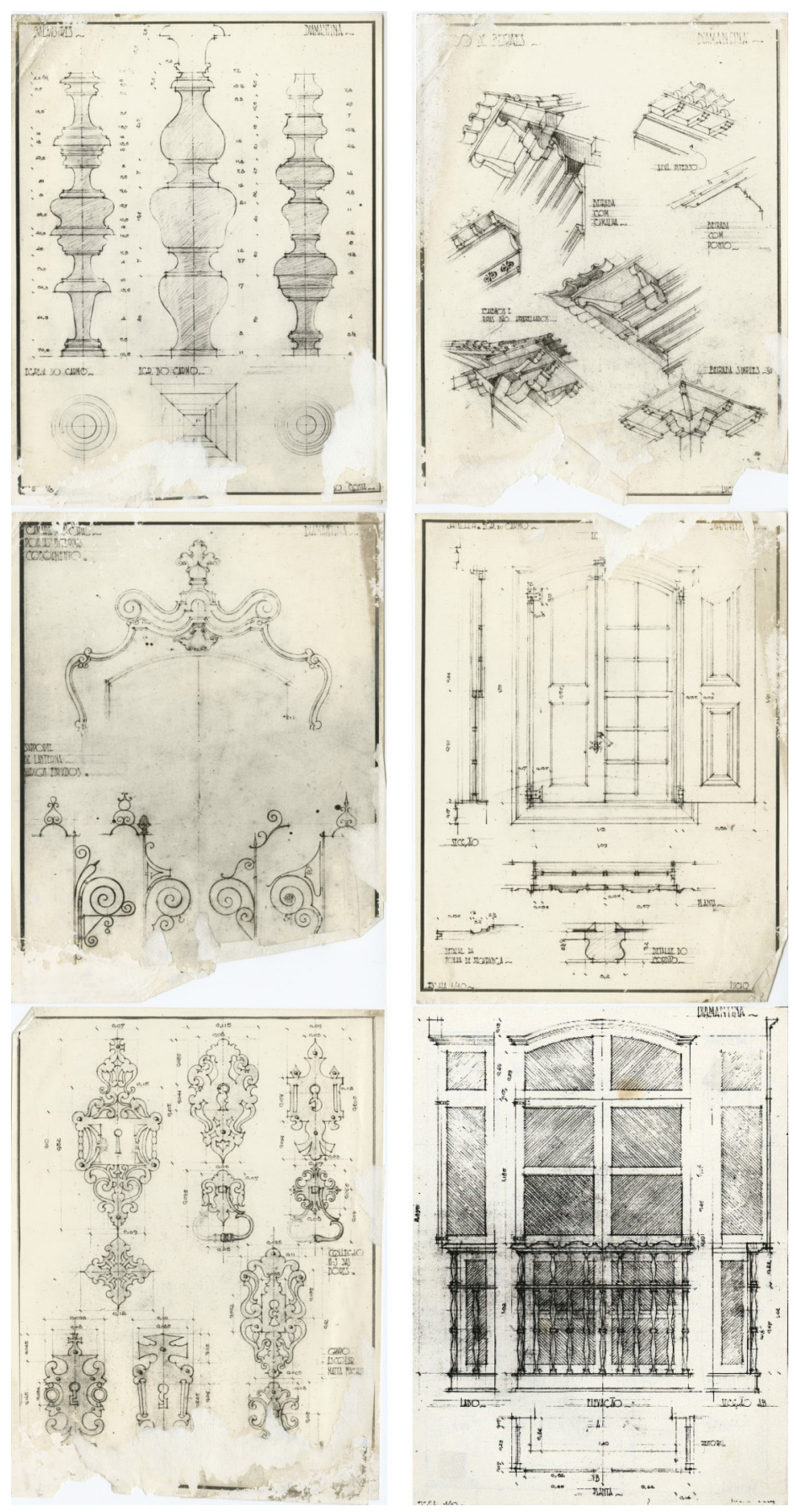

Figura 50: VILLA, 2018. Diagrama temático. FONTE: Acervo da autora. 
Nas pranchas do segundo grupo, são apresentados desenhos de estudos, possibilidades variadas de arranjo com os elementos construtivos "padrão" identificados no conjunto. Essa leitura da obra em elementos, feita pelo estudante-viajante, nos relembra a operação do viajante moderno, como em Le Corbusier, que extrai da obra que visita, a tipologia, e faz o processo de análise, que é justamente esse, o de separar a unidade em elementos para compreendêlos, e assim intuir novos arranjos, "novos projetos".

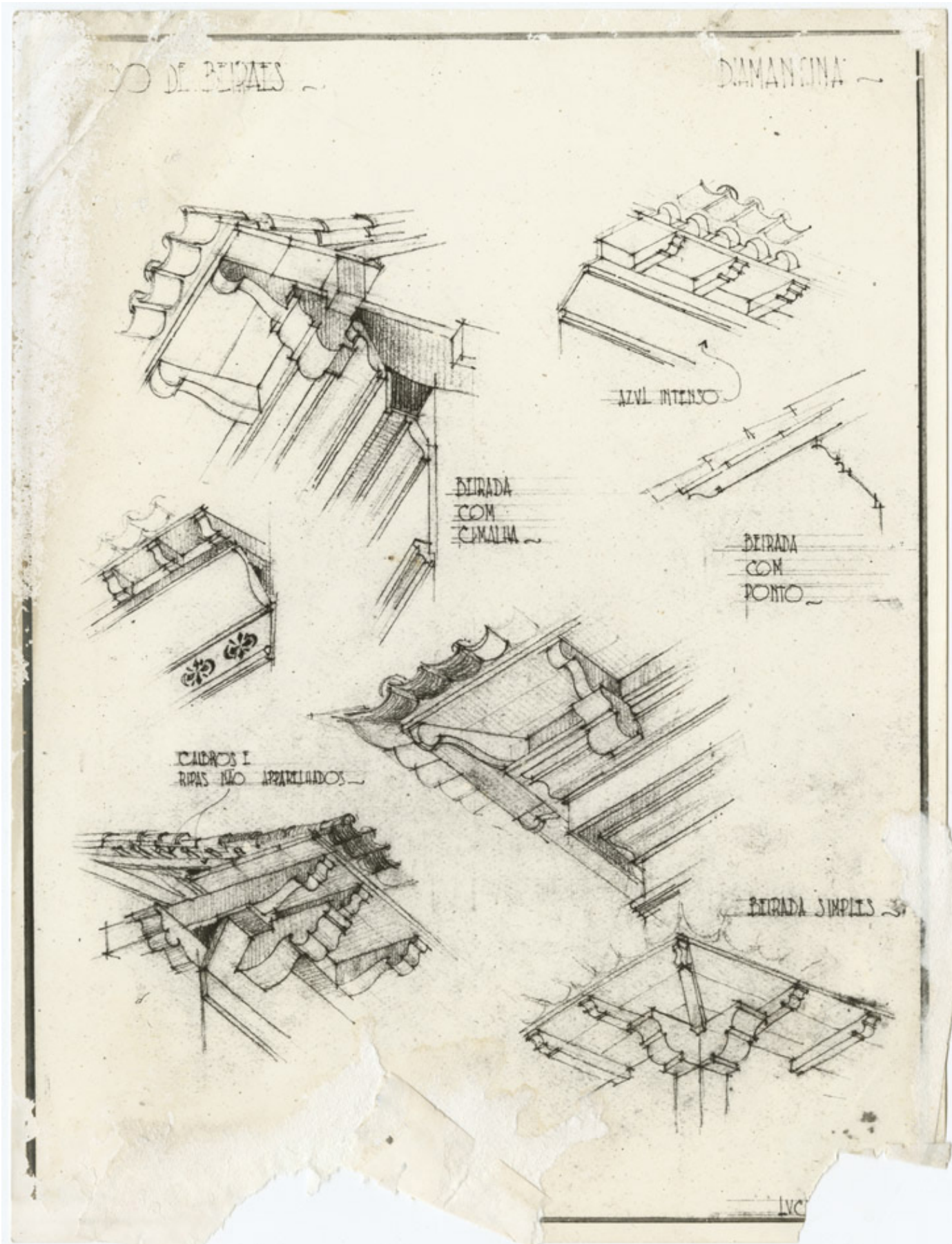

Figura 51: COSTA, Lucio. 1924. estudo de beirais, Diamantina. FONTE: Acervo: (Lucio Costa) Instituto Antônio Carlos Jobim. 


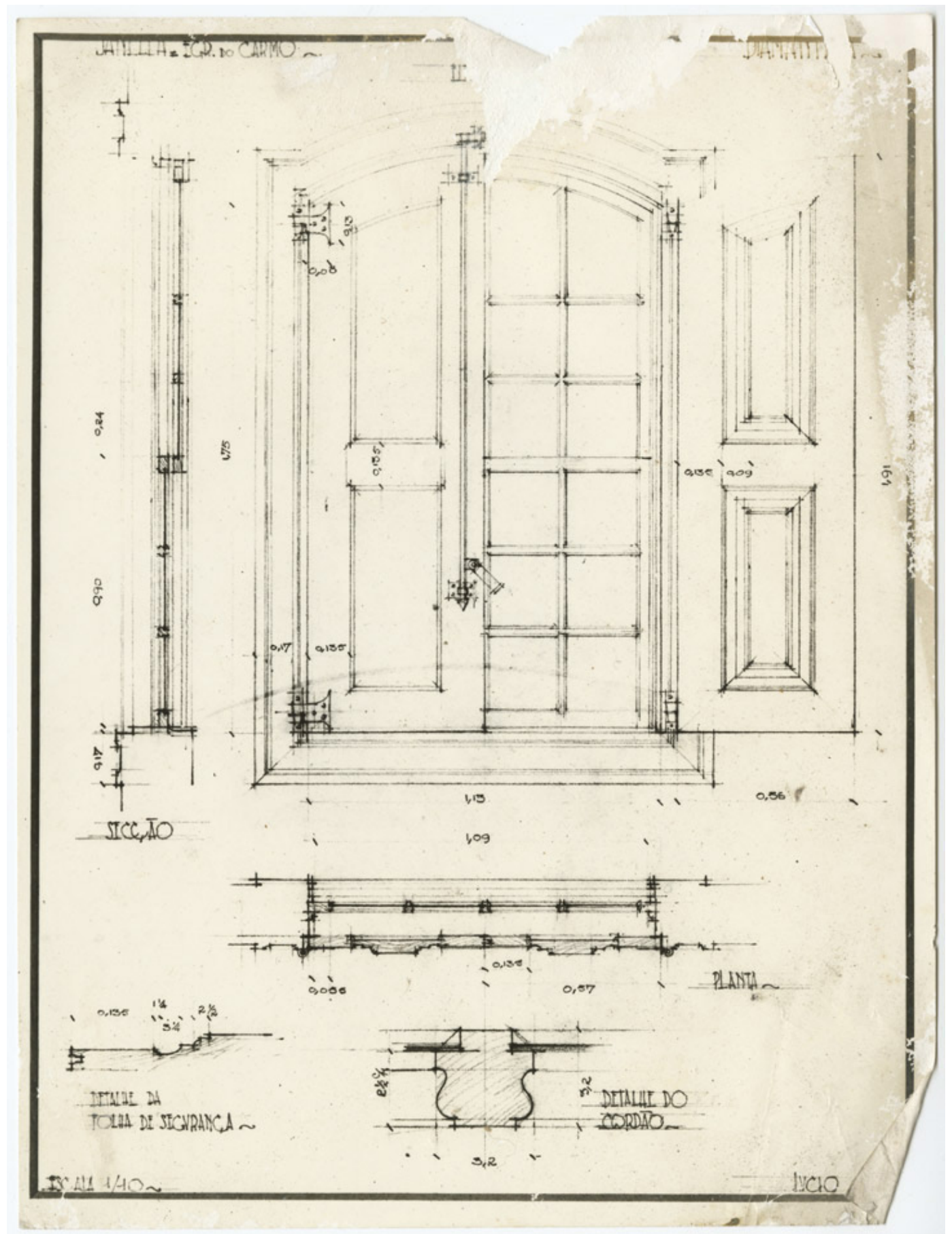

Figura 52: COSTA, Lucio. 1924. janela da Igreja N. S. do Carmo, planta e seções dos detalhes, Diamantina. FONTE: Acervo: (Lucio Costa) Instituto Antônio Carlos Jobim.

Podemos ler então, os desenhos dessa viagem de Lucio Costa lembrando da trajetória de formação de Le Corbusier, que realiza, assim como Lucio, enquanto jovem, em pleno processo de descoberta das tradições artísticas e arquitetônicas, se afirma no movimento moderno.

Lucio Costa viajante foi um viajante que deu ampla importância aos registros das viagens que ele percorreu. 0 registro, as anotações, como meio, como formato, conservam uma relação com a necessidade de conhecer o lugar 
e a possibilidade de um "retorno", de uma posterior reflexão, que é tão própria ao caderno de viagem.

As impressões registradas apontam a todo o momento para essa relação de pertencimento ao presente que ele tinha e de poder gerar um entendimento sobre esse, assim como proposições para um futuro.

\section{_outras viagens}

Ao considerar essa longa trajetória, podemos observar em Lucio Costa, em suas produções uma transição de posturas frente a uma mesma questão, a da correlação entre arquitetura moderna e vernacular, questão essa que começa a ser despertada na viagem que ele faz enquanto estudante em 1924.

Outra viagem, de preocupação similar, e mostrando a uma ampliação do interesse no patrimônio cultural vernacular brasileito foi a viagem para estudo e levantamento da arquitetura dos jesuítas no Povoado das Missões, no Rio Grande do Sul, em 1937.

Lucio percorre depois, Portugal, em duas viagens, uma em 1948 e outra em 1952. As viagens de Lucio sempre conservaram essa dupla relação, uma de caráter oficial, enquanto funcionário, diretor de órgãos públicos, estudante, e outra de caráter pessoal, que carrega seus questionamentos mais íntimos. Lucio faz essa viagem antes do Inquérito à Arquitetura Popular em Portugal. ${ }^{30}$

Lucio continua as investigações depois das sensíveis descobertas que faz em Diamantina. Empreende uma busca pelos paralelos entre a arquitetura colonial brasileira e a portuguesa, e assim planeja anos mais tarde, duas viagens a Portugal. Há uma aparente transição entre as viagens endereçadas a Minas Gerais e suas posteriores, a Portugal, transição que é visível também pelas diferenças dos desenhos e anotações produzidas, por exemplo, os desenhos produzidos nas viagens brasileiras são mais técnicos, com caráter de levantamento de patrimônio, de catalogação, diferente do material deixado pelas viagens portuguesas, onde os croquis aparecem com mais força e liberdade.

0 roteiro português ofereceu uma compreensão distinta da relação entre arte e arquitetura brasileira e portuguesa, e das próprias ideias de modernidade e tradição em relação ao resultado da primeira viagem, e também em relação às viagens brasileiras, todas foram realizadas com a mesma preocupação

30 investida de viagem de pesquisa que buscou mapear a arquitetura tradicional portuguesa, de forma sistemática, na década de 50. 
temática, porém esta última com um foco diferente, na autenticidade de cada produção.

Para Lucio a relação da arquitetura brasileira com a portuguesa não era um simples esquema de modelo e cópia, mas da confirmação da autenticidade de ambos. Não é novamente uma relação de dependência artística, e sim da existência de um vocabulário comum que foi desenvolvido nos diferentes países conservando cada qual uma autonomia. Era corrente, nessa época, ressaltar mais fortemente o aspecto das continuidades e não da autonomia, e para Lucio Costa, pensando dentro do movimento moderno, pareceu mais importante ressaltar as diferenças. Lucio Costa, aí sim definindo sua noção peculiar de modernidade, não vê oposição entre os conceitos de continuidade e autonomia, e sim uma convivência. Dessa forma, Lucio negava o apelo identitário promovido pelo movimento neocolonial, trazendo, para sua arquitetura, um novo jeito de ser moderno e tradicional ao mesmo tempo.

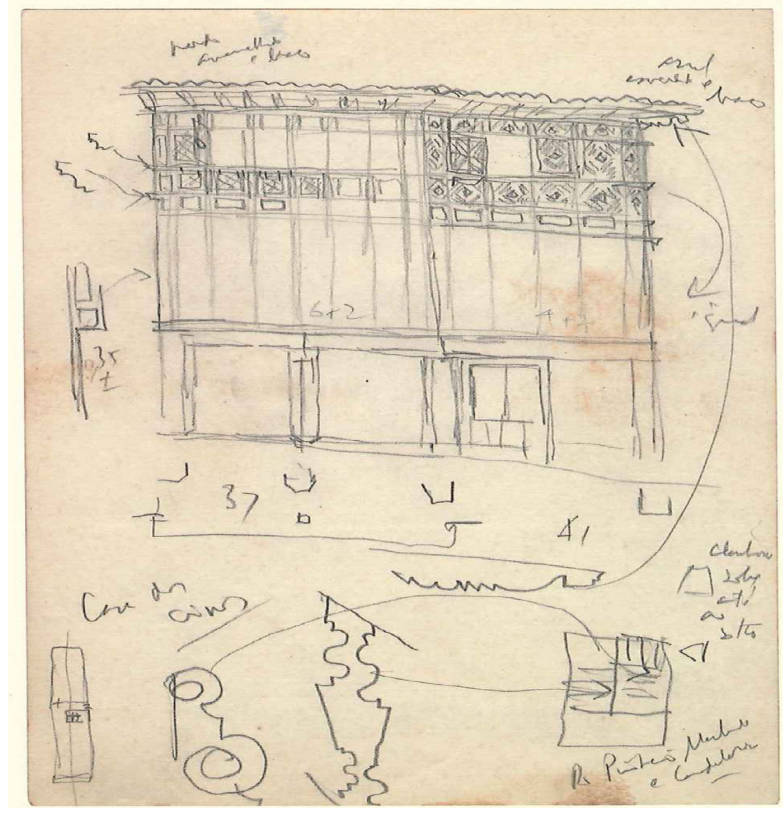

Observamos que as viagens em Lucio tiveram um papel transformador, de amadurecimento, de ter posto em suspensão seus próprios conceitos iniciais, ou seja, o contato com o lugar provocou reações do âmbito do inesperado.

Podemos ser acometidos por uma falsa ideia de que as viagens percorridas por Lucio Costa foram somente viagens de interesse em estudos patrimoniais, que o fixaria no passado, e no elogio a este. Mas, essas incursões do arquiteto no passado nos revelam mais, nos revelam as preocupação que ele tinha com o presente, e sobretudo com o futuro da arquitetura brasileira. "Se é absolutamente necessário regressar ao passado para perceber elos identitários, o registro não pode ser feito se se pretende lá ficar." (ARAUJO, 2012, p.264) 
CONSIDERAÇÕES FINAIS 


As viagens aqui apresentadas foram lidas na chave das viagens de formação, para todos os personagens a viagem representou uma experiência de revelação, em algum âmbito. Para Blaise, a viagem lhe desvela possibilidades temáticas, com as quais, até o momento das leituras de "Feuilles de route", começaram a ser exploradas. A matéria que o Brasil lhe forneceu seria amplamente explorada em muitas obras posteriores a 1924; para Tarsila, Minas possibilitou o encontro entre suas referências cubistas, "as cores que ela gostava desde a infância”, num elo entre vanguarda e tradição popular; para Mário, para quem a viagem começou antes, em 1919, o reencontro com o caráter popular, acomodado, e cheio de lirismo da arte e da arquitetura barrocas de Minas Gerais, influenciaram tanto a linguagem quando a postura cultural do intelectual; e finalmente, para Lucio Costa, a experiência de Minas naquela época foi o início de um desconforto, em relação ao movimento neocolonial em que se inseria, e que o arquiteto perseguiu, por muitos olhares atentos até se reconhecer moderno, em um diálogo com o legado das manifestações artísticas do passado.

Para as viagens enquanto momento de formação, perspectiva na qual se insere as experiências desses personagens-viajantes, o contato físico com o espaço, o objeto de estudo é importante para que seja possível uma plena experiência perceptiva, que aqui é fenomenológica, como assinala MerleauPonty. Fenômeno que é captado pelo viajante, confrontado e posteriormente registrado. Diferenciando então esses dois momentos, o último acontece pela mediação do primeiro, e só é possível produzi-lo, depois do entendimento do objeto, espaço que se olha.

Para que seja possível a leitura é necessário tornar heterogêneos os espaços através de uma operação da mente capaz de provocar um valor, um predicado, um juízo que atraia nossa atenção para fragmentos espaciais específicos e os imponha à nossa percepção, ou seja, que projete uma imagem pelo ambiente como um todo e atuem como um prolongamento, um índice dele. (FERRARA, 2007, p.23)

A viagem modena, uma atribuição direta do pensamento moderno se deu, na experiência desses viajantes na compreensão do espaço como heterogêneo, o qual não é rígido, não apresenta uma identidade asoluta.

0 modo peculiar com que esses personagens foram afetados pela viagem, pelos seus estímulos sensórios, e leram aquela realidade, se deu em um possível reconhecimento de unidade entre eles, pelo reconhecimento de elementos. 
Quando a leitura é feita com atenção ao reconhecimento de elementos, partes, dentro de uma unidade, e se compreende a natureza e o papel daquele elemento, ele não precisa mais fazer parte somente daquela realidade, daquele passado do qual fora extraído; como não o foi, o que se extraiu da arte barroca, enquanto conceito, enquanto linguagem, temática, foi empregado nas produções posteriores dos viajantes, foi revisitado.

Será difícil apontar noutra cultura tão importante, vasta e substanciosa soma de estudos como a que oferece a nossa "brasiliana", que ocupa um setor relevante de nossa história cultural, num plano em que se misturam e cooperam entre si a literatura, a filosofia, a história, a sociologia, a antropologia, a etnografia, a geografia, a linguística, a economia, etc., criando quase um gênero intelectual desconhecido de outros povos [...] é toda uma linhagem de pensamento e pesquisa acerca da terra e da gente brasileiras, para conhecer e revelar o país e o povo, a fim de dar aos brasileiros a consciência da sua civilização e cultura, e consolidar a sua fisionomia. (COUTINHO, 1988, p.237)

0 que o barroco faz pela primeira vez, que é resgatar uma experiência, um conceito artístico que já havia sido desenvolvido na Europa e acomodar na realidade e necessidades construtivas e artísticas brasileiras de um determinado período, é o que os modernistas brasileiros queriam conseguir fazer com os conceitos de arte e arquitetura moderna, usar desse conjunto de preceitos do modernismo internacional, das vanguardas artísticas misturado com uma "sensibilidade nacional".

Lembrando que a noção de barroco mineiro foi sendo elaborada na medidaa ao mesmo tempo em que a escolha e as investigações da viagem. Nesse sentido, essa denominação e a atribuição de sentido se deram posteriormente à sua manifestação em si, no Brasil do século XVIII.

A viagem de 1924 deu aos viajantes a possibilidade de entender procedimentos, de ler uma manifestação artística tradicional em seu conjunto e nas suas partes. Depois dessa experiência, todos os quatro personagensviajantes continuaram suas trajetórias, mantendo, por mais diversos os roteiros, uma afinidade com a pesquisa que se iniciou em Minas.

Outro modo pelo qual a viagem de 1924 teve reverberações foi através das retomadas desta pela evocação reflexiva, que refazia a mesma viagem, na revisão das anotações, na edição dos diários, nas obras pintadas e construídas. 
Essas trajetórias provocaram ressonâncias no decorrer do desenvolvimento do movimento moderno tanto no campo das artes quanto na arquitetura no Brasil, por colocarem um foco temático em questões que ainda não haviam sido discutidas no país. Os resultados, materiais coletados nessas viagens, foram cruciais para criar uma base de registros sobre a qual se tornou possível pensar, por exemplo, as práticas patrimoniais.

Os registros colecionados dessas viagens nos revela, como instância primeira, potência primária da impressão vivida "in loco", no primeiro contato, no estranhamento, na anotação que vacila. Talvez seja nesse material que encontremos as ambiguidades da ideia de um artista.

Tratamos, nesse trabalho, de quatro personagens-viajantes, que, por mais que tenham percorrido o mesmo roteiro, com questionamentos semelhantes acerca da tradição na arte brasileira, a impressão que cada um deles teve da viagem foi plural, porque se considera a bagagem cultural do viajante. Nesse sentido, os registros também foram plurais.

Mesmo sob essa ótica, podemos ler elos entre as impressões dos viajantes, manifestados, tantos nos registros, verbais e visuais, quanto na postura intelectual e profissional que assumiram desde a viagem. Todos os quatro personagens se construíram como "porta-vozes da modernidade cultural", ainda que ligados à tradição, tradição que visitam em Minas Gerais; cada um em seu campo disciplinar, artística, Blaise e Mário na literatura, na qual a temática e a linguagem inovadora são indissociáveis; Tarsila, nas artes visuais, quando pinta com uma originalidade vanguardista, uma questão tradicional, e Lucio, que elege "as manifestações culturais populares, coletivas, rurais e anônimas como base para a criação de uma cultura moderna" ${ }^{31}$ na arquitetura.

Quando de olha para o registro, como por exemplo, com o interesse dessa pesquisa, se olha também para a construção de uma tradição. Essas viagens de estudo abordadas no trabalho, dirigidas ao interior do Brasil que olhou para o tradicional das manifestações artísticas no país acabaram por gerar uma nova tradição disciplinar.

Tradição disciplinar que pode der compreendida como via de pesquisa e aprendizado em arquitetura, chegando às grades curriculares das escolas de arquitetura, como etapa fundamental da formação dos alunos.

31 Guilherme Wisnick em seu texto: "Plástica e anonimato: modernidade e tradição em Lucio Costa e Mário de Andrade”, 2007, p.169. 
REFERÊNCIAS BIBLIOGRÁFICAS 


ALEM, Branca Puntel Motta. As amizades Brasileiras de Blaise Cendrars: uma análise de Feuilles de Route. Dissertação de mestrado. UFMG. Belo Horizonte, 2011.

AMARAL, Cláudio Silveira. John Ruskin. Iluminista ou adepto da filosofia da Idade Média? Arquitextos, São Paulo, ano 13, n. 152.01, Vitruvius, jan. 2013 <http://www.vitruvius.com.br/revistas/read/arquitextos/13.152/4595>.

AMARAL, Aracy. Tarsila: sua obra e seu tempo. São Paulo: Perspectiva: EDUSP, 1975. (Estudos, 33).

Arquitectura Neocolonial: América Latina, Caribe, Estados Unidos. São Paulo: Memorial da America Latina/ Fondo de Cultura Econômica, 1994.

Artes Plásticas na Semana de 22. São Paulo: Perspectiva, 1970, pp.50-65; AMARAL, A. (org.), Arquitectura Neocolonial: América Latina, Caribe, Estados Unidos, São Paulo, Memorial da America Latina/ Fondo de Cultura Econômica, 1994, pp. 147-64, 249-58; BATISTA, M.R., Centenários Modernistas II: Antonio Garcia Moya (1891-1949), São Paulo, Instituto de Estudos Brasileiros, 1991.

ANDRADE, Mario de. 0 turista aprendiz. Brasília: IPHAN, 2015.

“O Aleijadinho (1928)” in Aspectos das Artes Plásticas no Brasil, Belo Horizonte, Itatiaia, 1984, pp.39-41.

“A arte religiosa no Brasil”. São Paulo: Experimento Giordano, 1995.

ANDRADE, Carlos Drummond de. Firewell. In Poesia Completa. Rio de Janeiro: Nova Aguilar, 2002.

ANDRIOLO, Arley. Metamorfoses do olhar na viagem de Goethe à Itália. ArtCultura, Uberlândia, v. 13, n. 23, p. 113-127, jul.-dez. 2011.

ARAUJO, Renata Malcher. Pósfacio. In PESSOA, José. COSTA, Maria Elisa. (org.). Bloquinhos de Portugal. A arquitetura brasileira no traço de Lúcio Costa. Rio de Janeiro: Funarte, 2012.

BARBATO, Luis Fernando Tosta. Relatos de Viajantes: de meras histórias de aventura ao saber voltado à instrução política. Anais do XXI Encontro Estadual de História ANPUH-SP. Campinas, setembro, 2012.

BATISTA, Eduardo Luís Araújo. Blaise Cendrars - o terceiro elemento do movimento Pau Brasil. Itinerários, Araraquara, n.33.p.139-156, jul./ dez.2011.

BELLUZZO, Ana Maria. O Brasil dos Viajantes. São Paulo: Fundação E. Odebrecht, 1994. 
BELUZZO, Ana Maria. A propósito d'o Brasil dos viajantes. Revista USP, São Paulo (30): 8-19, junho/agosto 1996. p.06-19.

BENATTI, Antonio Paulo. "História, Ciência, Escritura e Política" In RAGO, Margareth \& GIMENES, Renato Aloizio de Oliveira (orgs.). Narrar o Passado, Repensar a História. Campinas-SP: UNICAMP, Instituto de Filosofia e Ciências Humanas, 2000.

BROCA, Brito. Blaise Cendrars no Brasil, em 1924. A Manhã, Rio de Janeiro, 4 de maio 1952. Apud AMARAL, Aracy. Blaise Cendrars no Brasil e os modernistas. São Paulo, Martins, 1997. p. 58-59.

CANDIDO, Antonio \& CASTELLO, José Aderaldo. Presença da Literatura Brasileira - História e Antologia - Modernismo. Rio de Janeiro, Bertrand Brasil, 15a edição, 1996.

CALIL, Carlos Augusto. A POESIA DE OLHO NO CINEMA. Texto de apresentação Mostra de Filmes do Colóquio Internacional "Brasil: a Utopialândia de Blaise Cendrars". Agosto de 1997. http://cinusp.dobralab.com. br/mostra/1997/08/blaise cendrars no cinema acesso em 03/02/2018.

Cinema = "Digging" Cendroswald Cinema Productions. Revista IEB n47 setembro de 2008. pp.13-28.

CARDOSO, Ana Paula. Fotografias verbais e diálogos entre artes: Pau Brasil, Feuilles de Route e desenhos de Tarsila. Dissertação de mestrado. FFLCH-USP. São Paulo, 2006.

CARDOSO, Sérgio. 0 olhar viajante (do etnólogo). Em NOVAES, Adauto (org.). O olhar. São Paulo: companhia das letras, 1988, pp. 347-360.

CENDRARS, B. Etc..., etc...: (Um livro 100\% brasileiro). Tradução e seleção de Teresa Thiériot. São Paulo: Perspectiva, 1976.

0 filme 100\% brasileiro. São Paulo, 1o. de junho de 1924. Tradução e notas: Carlos Augusto Calil. revista ieb n47 setembro de 2008. pp.201-214.

Feuilles de Route/ Sud-Américaines (Poèmes), Folhas de Viagem/ Sul-Americanas(Poemas). Belém: Editora Universitária UFPA, 1991. Trad. Sérgio Wax. Edição bilíngüe.

Blaise Cendrars - Poemas - 0 Panamá ou As Aventuras dos meus Sete Tios / 19 Poemas Elásticos / A Guerra no Luxemburgo / Poemas Negros. Belém: Editora Universitária UFPA, 1993. Trad. Sérgio Wax. Edição Bilíngüe.

CORBUSIER, Le. Le Corbusier. Il Linguaggio delle pietre. (catálogo da mostra org. por Giuliano Gresleri), Venezia: Marsilio,1988.

Il viaggio in Toscana (1907). (catálogo da mostra org. por Giuliano 
Gresleri), Venezia: Marsilio, 1987.

A viagem ao oriente. São Paulo: Cosac \& Naify, 2007.

COSTA, Lucio. Registro de uma vivência. São Paulo: Empresa das Artes/ UNB, 1995.

“Considerações sobre nosso gosto e estilo”. A Noite, 18/6/1924. In: Registro de uma vivência. São Paulo: Empresa das Artes/UNB, 1995.

COUTINHO, Afrânio (1976). Introdução à Literatura no Brasil. Rio de Janeiro, Ed. Bertrand Brasil, 13ª edição, 1988.

DIENER, Pablo. COSTA, Maria de Fátima. A arte dos viajantes: de documentadores a artistas viajantes. Perspectivas de um novo gênero. Revista Porto Arte: 76 Porto Alegre, v. 15, no 25, novembro/2008. p. 75-100.

ENGEL, Pedro. "Produzindo um corpo sensível. Algumas idéias para (re)pensar a aprendizagem da percepção na formação do arquiteto". Arquitextos. São Paulo, 2009.106.04<http://www.vitruvius.com. $\mathrm{br} / \mathrm{revistas} / \mathrm{read} /$ arquitextos/09.106/67> . (acesso em: 22/09/2015).

EULALIO, Alexandre. A aventura brasileira de Blaise Cendrars: ensaio, cronologia, filme, depoimentos, antologia,desenhos, conferências, correspondência, traduções. CALIL, Carlos Augusto (org.). São Paulo: Edusp, 2001.

FERRARA, Lucrécia D’alessio. Leitura sem palavras. São Paulo: Ática, 2009.

FOUCUALT, Michel. A ordem do discurso. L'Ordre du discours, Leçon inaugurale ao Collège de France prononcée le 2 décembre 1970, Éditions Gallimard, Paris, 1971. Tradução de Edmundo Cordeiro. Eca-usp. Julho de 2002.

Nietzsche, a genealogia e a História. In Microfísica do poder. São Paulo: Paz E Terra, 2014. p.18. 28ํed.

GALVÃO, Patrícia. Nove poemas de Blaise Cendrars. A Tribuna, $2^{\underline{o}}$ Caderno, 09/09/1956.

GRESLERI, Giuliano (a cura de). Catalogo da mostra Viaggio in Oriente: gli inediti di C.E. Jeanneret. fotografo e scritore - (com uma nota de Italo Zannier sobre Le Corbusier fotógrafo). Venezia, Marsilio/Fondation Le Corbusier, 1984.

GOETHE, Wolfgan von. Viagem à Itália 1786-1788. Tradução: Sérgio Tellaroli. São Paulo: Companhia das Letras, 1999.

GONÇALVES, José Fernando de Castro. Motivação e consequência da viagem na arquitetura de Le Corbusier: viagem ao Oriente e América 
Latina. Cadernos PROARQ18. Rio de Janeiro: UFRJ, 2012. pp.196-214.

HUMBOLDT, Alexander von. 1998. 'Essai sur la géographie des plantes' (1807). Em P. Acot (org.).

IANNI, Otávio. A metáfora da viagem. In: Revista de Cultura Vozes, Petrópolis, ano 90, v.90, n.2, mar./abr. 1996.

JANCSÓ, István (org.). Brasil: formação do Estado e da Nação. São Paulo: Hucitec, Unijuí, Fapesp, 2003 (Estudos Históricos, 50).

KURY, Lorelai. "Viajantes-naturalistas no Brasil oitocentista: experiência, relato e imagem". História, Ciência, Saúde - Manguinhos. Vol. VIII (suplemento), 2001.

LAFETÁ, João Luiz. 1930: a crítica e o modernismo. São Paulo: Duas Cidades/Ed. 34, 2000.

LANCHA, Joubert J. 0 olho e a mão, o desenho na primeira viagem de Le Corbusier. Revista Risco, n.4-2, 2006, pp.51-66.

LEED, Eric J. La mente Del viaggiatore: dalYOdissea al turismo globale. Bologna: Il Mulino, 1992.

LIMA, Alceu Amoroso. Europa de hoje. Rio de Janeiro: Agir, 1951.

LIRA, José Tavares Correia de. O estranho patrimonial: Mário de Andrade e o (des)Brasil. In. ANDRADE, Mario de. 0 turista aprendiz. Brasília: Iphan, 2015. p.365-391.

Localismo Crítico e Cosmopolitismo Arquitetônico Mário de Andrade e a Informação Moderna de Arquitetura (1925-1929). II Seminário DO.CO.MO.MO. Brasil. A Permanência do Moderno Pavilhão da Bienal do Ibirapuera. 8-11 de dezembro de 1999.

LISBOA, Karen. A Nova Atlântida de Spix e Martius: natureza e civilização na viagem pelo Brasil (1817 - 1820). São Paulo: HUCITEC, 1997.

LOPEZ, Telê Ancona. Estabelecimento do texto, introdução e notas. In: ANDRADE, Mário de. 0 turista Aprendiz. Belo Horizonte: Itatiaia, 2002.

Viagens etnográficas de Mário de Andrade in Andrade, Mário. 0 turista aprendiz. São Paulo: Duas Cidades / Secretaria da Cultura, Ciência e Tecnologia, 1976.

MASCARO, Luciana Pelaes. BORTOLUCCI, Maria Ângela. LOURENÇO, Júlia Maria. Ricardo Severo, Raul Lino e os Movimentos Tradicionalistas. Revista Convergência Lusíada. Número 25 - jan/jun de 2011. Acesso em: 26/08/2016 http://www.realgabinete.com.br/revistaconvergencia/?p=187

MARTINS, Wilson. “Cendrars e o Brasil”. Hispania 4, E.U.A., vol.75, outubro de 1992. Recolhido em Pontos de Vista, vol.13. São Paulo: T.A. Queiroz, 
1997, p.112. In. EULALIO, Alexandre. A aventura brasileira de Blaise Cendrars: ensaio, cronologia, filme, depoimentos, antologia, desenhos, conferências, correspondência, traduções. CALIL, Carlos Augusto (org.). São Paulo: Edusp, 2001. p.490-502.

MARTIUS, Carl F. P. von. 1828-34. Icones Selectae Plantarum Cryptogamicarum. Munique, C. Wolf.

1823-53. Historia Naturalis Palmarum. Leipzig, T. 0. Weigel.

1943. 'A fisiononomia do reino vegetal no Brasil'. Arquivos do Museu Paraense, vol. III, pp. 239-71. (1824).

1996. A viagem de von Martius (Flora Brasiliensis, vol. I, 1840). Rio de Janeiro, Index.

MARTIUS, Carl F. P. von e Spix, Johann Baptist von 1981. Viagem pelo Brasil. Belo Horizonte/São Paulo, Itatiaia/Edusp, 3 vols. (1823-31).

MERLEAU-PONTY, Maurice. A fenomenologia da percepção. São Paulo: Martins fontes, 1999.

MICELI, Paulo. 0 ponto onde estamos: viagens e viajantes na história da expansão e da conquista. São Paulo: Página Aberta, 1994.

OLIVEIRA, Silvana M. Pessôa. De viagens e de viajantes: a viagem imaginária e o texto literário. Belo Horizonte: FALE/UFMG, 1995. (Tese, Doutorado) (Mimeo).

PEREIRA, Sonia Gomes. “O ensino de arquitetura e a trajetória dos alunos brasileiros na École dês Beaux-Arts em Paris no início do século XIX" in: 185 anos de Escola de Belas Artes. Rio de Janeiro: UFRJ, 2001/2002.

PESSOA, José, COSTA, Maria Elisa (org.). Bloquinhos de Portugal. A arquitetura brasileira no traço de Lucio Costa. Funarte. Rio de Janeiro, 2013.

PIMENTEL, Thaís Velloso Cougo. Viajar e narrar: toda viagem destinase a ultrapassar fronteiras. VARIA HISTORIA, Belo Horizonte, $\mathrm{n} \times$ 25, Jul/2001, pp.81-120.

RIBEIRO, Mônica C. Arqueologia modernista: viagens e reabilitação do primitivo em Mário e Oswald de Andrade. Campinas, Departamento de Antropologia do IFCH-UNICAMP, 2005, pp.41-2.

SALGUEIRO,Valeria. Grand Tour: uma contribuição à história do viajar por prazer e por amor à cultura. Revista Brasileira de História, São Paulo, v.22, n-44, 2002.

SANTOS, Marcelo Burgos Pimentel dos. Viagens de Mário de Andrade: a construção cultural do Brasil. Tese de doutorado PUC-SP. São Paulo, 2012.

SCHIAVINATTO, Iara Lis. "Imagens do Brasil: Entre a natureza e a 
História" In JANCSÓ, Istvan. Brasil: Formação do Estado e da Nação. São Paulo: HUCITEC; Ed. Unijuí; Fapesp, 2003.

SILVA, Joana Mello de Carvalho e. CASTRO, Ana Claudia Veiga de. Inventar o passado, construir o futuro: São Paulo entre nacionalismos e cosmopolitismos nas primeiras décadas do século 20. Revista Pós FAUUSP. V.21 nํ36. Dezembro de 2014. p.24-54.

Da arqueologia portuguesa à arquitetura brasileira. Revista do IEB. №43. Setembro de 2006.

SODRÉ, João Clark de Abreu. Arquitetura e viagens de formação pelo Brasil 1938-1962. Dissertação de mestrado FAU-USP, 2010.

SÜSSEKIND, Flora. 0 Brasil não é longe daqui. 0 narrador, a viagem. São Paulo: Companhia das Letras, 1990.

Literatura e vida literária. Polêmicas, diários \& retratos. Belo Horizonte: Editora UFMG, 2004.

UZEDA, Helena C. de. "O ensino de arquitetura da Academia de Belas Artes: 1826-1889", in: 185 anos de Escola de Belas Artes. Rio de Janeiro: UFRJ, 2001/2002, pp. 41-67.

WISNIK, Guilherme. Plástica e anonimato: modernidade e tradição em Lucio Costa e Mario de Andrade. Revista Novos Estudos, nํ79, 2007, p.169-193. 
_consulta aos acervos

Arquivo Mario de Andrade IEB

CD-ROM - Os diários do fotógrafo Programador Patrick Josef Levy Ômiccron P.G. Ltda.

Catálogo Raisonné Tarsila do Amaral 
ANEXOS 




\section{fonte das imagens do diagrama linha do tempo:}

1. AMARAL, Tarsila do. 1924. Capa de "Feuilles de Route". FONTE: Acervo IEB-USP.

2. AMARAL, Tarsila do. serra da Mantiqueira - Rio Paraíba. (Ilustração publicada no livro Feuilles de Route, p.64.) 1924. . FONTE: Catálogo Raisonné Tarsila do Amaral.

3. CENDRARS, Blaise. 1924. Boneco da capa de "Le Formose". FONTE: Fonds Blaise Cendrars, Archives Littéraires Suisses, Bibliiothèque Nationale, Berna.

4. ANDRADE, Mario de. Desenho da Igreja N. S. Do Carmo. 1924. FONTE: Arquivo Mario de Andrade IEB-USP.

5. VILLA, 2018. Foto da capa de “O Turista Aprendiz”, Edusp (1993). FONTE: Acervo da autora.

6. ANDRADE, Mário de. Fotografia da viagem etnográfica. 1927. FONTE: Arquivo Mario de Andrade IEB-USP.

7. DI CAVALCANTI, 1922. Projeto da capa para "Paulicéia desvairada". FONTE: Coleção Mário de Andrade - Coleção de Artes Visuais do Instituto de Estudos Brasileiros - USP.

8. AMARAL, Tarsila do. 1924. Croqui Carnaval no Rio de Janeiro. FONTE: Catálogo Raisonné Tarsila do Amaral.

9. AMARAL, Tarsila do. 1924. Esboços série viagem a Minas Gerais. FONTE: Catálogo Raissoné Tarsila do Amaral.

10. DI CAVALCANTI, 1928. Projeto para a capa de "Macunaíma". FONTE: Wikemedia Communs.

11. AMARAL, Tarsila do. 1924. Paisagem mineira. FONTE: revista eletrônica vitruvius.

12. AMARAL, Tarsila do. 1924. Ouro Preto. FONTE: Catálogo Raisonné Tarsila do Amaral.

13. AMARAL, Tarsila do. 1928. "O Abaporu”. FONTE: Catálogo Raisonné Tarsila do Amaral.

14. AMARAL, Tarsila do. 1924. E.F.B.C. FONTE: Catálogo Raisonné Tarsila do Amaral.

15. COSTA, Lucio. 1924. levantamento de muxarabi, Diamantina. FONTE: Acervo: (Lucio Costa) Instituto Antônio Carlos Jobim. 
16. COSTA, Lucio. 1924. aquarela passadiço de Diamantina. FONTE: Acervo: (Lucio Costa) Instituto Antônio Carlos Jobim.

17. COSTA, Lucio. 1924. estudo de beirais, Diamantina. FONTE: Acervo: (Lucio Costa) Instituto Antônio Carlos Jobim.

18. COSTA, Lucio. 1924. câmara principal; portas interna; coroamento; suporte de lanterna; vários estudos, Diamantina. FONTE: Acervo: (Lucio Costa) Instituto Antônio Carlos Jobim.

19. COSTA, Lucio. Croqui de Guimarães, Portugal. FONTE: Fotografia José Pessoa. 2013. P.124. PESSOA, José, COSTA, Maria Elisa (org.). Bloquinhos de Portugal. A arquitetura brasileira no traço de Lucio Costa. Funarte. Rio de Janeiro, 2013.

20. COSTA, Lucio. Bloquinhos de Portugal. FONTE: Fotografia Julieta Sobral. 2013. P.10. PESSOA, José, COSTA, Maria Elisa (org.). Bloquinhos de Portugal. A arquitetura brasileira no traço de Lucio Costa. Funarte. Rio de Janeiro, 2013.

21. VILLA, 2018. Foto da capa de "Arte religiosa no Brasil", Experimento Giordano (1993). FONTE: Acervo da autora. 


\section{_fontes das imagens usadas nos diagramas t.a.:}

\section{_série ilustrações:}

1. casario e montanha. Tarsila do Amaral, 1924. FONTE: Catálogo Raisonné Tarsila do Amaral (Ilustração publicada no livro Feuilles de Route, p.14.)

2. paisagem com estrada e igreja. Tarsila do Amaral, 1924. FONTE: Catálogo Raisonné Tarsila do Amaral (Ilustração publicada no livro Feuilles de Route, p.19.)

3. paisagem mineira. Tarsila do Amaral, 1924. FONTE: revista eletrônica vitruvius.

4. ilhas. Tarsila do Amaral, 1924. FONTE: Catálogo Raisonné Tarsila do Amaral (Ilustração publicada no livro Feuilles de Route, p.34.)

5. ilhas com barquinho. Tarsila do Amaral, 1924. FONTE: Catálogo Raisonné Tarsila do Amaral (Ilustração publicada no livro Feuilles de Route, p.56.)

6. serra da Mantiqueira - Rio Paraíba. Tarsila do Amaral, 1924. FONTE: Catálogo Raisonné Tarsila do Amaral (Ilustração publicada no livro Feuilles de Route, p.64.)

7. locomotiva. Tarsila do Amaral, 1924. FONTE: Catálogo Raisonné Tarsila do Amaral (Ilustração publicada no livro Feuilles de Route, p.70.)

8. capa. Tarsila do Amaral, 1924. FONTE: Catálogo Raisonné Tarsila do Amaral (Ilustração publicada no livro Feuilles de Route, original da capa).

_série Carnaval no Rio de Janeiro:

1. detalhes e gente na rua. Tarsila do Amaral, 1924. FONTE: Catálogo Raisonné Tarsila do Amaral

2. carro de corso. Tarsila do Amaral, 1924. FONTE: Catálogo Raisonné Tarsila do Amaral

3. pessoas caminhando, igreja e paisagem. Tarsila do Amaral, 1924. FONTE: Catálogo Raisonné Tarsila do Amaral

4. adereços, figura e paisagem. Tarsila do Amaral, 1924. FONTE: Catálogo Raisonné Tarsila do Amaral

5. Carnaval em Madureira. Tarsila do Amaral, 1924. FONTE: Catálogo Raisonné Tarsila do Amaral

6. Escola de samba: adereços. Tarsila do Amaral, 1924. FONTE: Catálogo Raisonné Tarsila do Amaral

7. pessoas caminhando e igreja ao fundo. Tarsila do Amaral, 1924. FONTE: Catálogo Raisonné Tarsila do Amaral

8. estudo de Morro de favela. Tarsila do Amaral, 1924. FONTE: Catálogo Raisonné Tarsila do Amaral

9. igreja com paisagem de morro ao fundo. Tarsila do Amaral, 1924. FONTE: Catálogo Raisonné Tarsila do Amaral 


\section{_série viagem a Minas:}

1. Ouro Preto I. Tarsila do Amaral, 1924. FONTE: Catálogo Raisonné Tarsila do Amaral

2. Barra do Piraí. Tarsila do Amaral, 1924. FONTE: Catálogo Raisonné Tarsila do Amaral

3. Cendrars e morraria. Tarsila do Amaral, 1924. FONTE: Catálogo Raisonné Tarsila do Amaral

4. desvio em estação. Tarsila do Amaral, 1924. FONTE: Catálogo Raisonné Tarsila do Amaral

5. dois panoramas: Ouro Preto e Mariana. Tarsila do Amaral, 1924. FONTE: Catálogo Raisonné Tarsila do Amaral

6. Fundo de quintal I. Tarsila do Amaral, 1924. FONTE: Catálogo Raisonné Tarsila do Amaral

7. Lagoa santa: casa com cerca e vista de Sabará. Tarsila do Amaral, 1924. FONTE: Catálogo Raisonné Tarsila do Amaral

8. Capela Nova. Tarsila do Amaral, 1924. FONTE: Catálogo Raisonné Tarsila do Amaral

9. fundo de quintal II. Tarsila do Amaral, 1924. FONTE: Catálogo Raisonné Tarsila do Amaral

10. Juataba e Carmo de Matta. Tarsila do Amaral, 1924. FONTE: Catálogo Raisonné Tarsila do Amaral

11. estrada. Tarsila do Amaral, 1924. FONTE: Catálogo Raisonné Tarsila do Amaral

12. casa de fazenda com varanda e monumento. Tarsila do Amaral, 1924. FONTE: Catálogo Raisonné Tarsila do Amaral

13. Congonhas: vista de rua - detalhes de ornamentação (Itaverava). Tarsila do Amaral, 1924. FONTE: Catálogo Raisonné Tarsila do Amaral

14. Congonhas. Tarsila do Amaral, 1924. FONTE: Catálogo Raisonné Tarsila do Amaral

15. elemento decorativo com anotações de cor. Tarsila do Amaral, 1924. FONTE: Catálogo Raisonné Tarsila do Amaral

16. estação de trem. Tarsila do Amaral, 1924. FONTE: Catálogo Raisonné Tarsila do Amaral

17. estudo de locomotiva e passagem de nível. Tarsila do Amaral, 1924. FONTE: Catálogo Raisonné Tarsila do Amaral

18. vista de Mariana. Tarsila do Amaral, 1924. FONTE: Catálogo Raisonné Tarsila do Amaral

19. Ouro Preto III. Tarsila do Amaral, 1924. FONTE: Catálogo Raisonné Tarsila do Amaral

20. Ouro Preto e Padre Faria - estudos. Tarsila do Amaral, 1924. FONTE: Catálogo Raisonné Tarsila do Amaral

21. Ouro Preto e Padre Faria. Tarsila do Amaral, 1924. FONTE: Catálogo 
Raisonné Tarsila do Amaral

22. Ouro Preto II. Tarsila do Amaral, 1924. FONTE: Catálogo Raisonné Tarsila do Amaral

23. paisagem de Tiradentes com dois panoramas e fachada de igreja. Tarsila do Amaral, 1924. FONTE: Catálogo Raisonné Tarsila do Amaral

24. paisagem com cadeia de montanhas ao fundo. Tarsila do Amaral, 1924. FONTE: Catálogo Raisonné Tarsila do Amaral

25. rua de Sabará: detalhes de ornamentação. Tarsila do Amaral, 1924. FONTE: Catálogo Raisonné Tarsila do Amaral

26. procissão em Tiradentes com Verônica. Tarsila do Amaral, 1924. FONTE: Catálogo Raisonné Tarsila do Amaral

27. na igreja: Semana Santa. Tarsila do Amaral, 1924. FONTE: Catálogo Raisonné Tarsila do Amaral

28. São João del Rei: rua com igreja ao fundo. Tarsila do Amaral, 1924. FONTE: Catálogo Raisonné Tarsila do Amaral

29. São João del Rei e casa de pedra. Tarsila do Amaral, 1924. FONTE: Catálogo Raisonné Tarsila do Amaral

30. Tiradentes. Tarsila do Amaral, 1924. FONTE: Catálogo Raisonné Tarsila do Amaral

31. Tiradentes - rua e estudos diversos. Tarsila do Amaral, 1924. FONTE: Catálogo Raisonné Tarsila do Amaral

32. rua de Tiradentes. Tarsila do Amaral, 1924. FONTE: Catálogo Raisonné Tarsila do Amaral 


\section{_fontes das imagens usadas nos diagramas l.c.:}

1. COSTA, Lucio. 1924. janela da Igreja N. S. do Carmo, planta e seções dos detalhes, Diamantina. FONTE: Acervo: (Lucio Costa) Instituto Antônio Carlos Jobim.

2. COSTA, Lucio. 1924. estudo de beirais, Diamantina. FONTE: Acervo: (Lucio Costa) Instituto Antônio Carlos Jobim.

3. COSTA, Lucio. 1924. balaústres Igreja N. S. do Carmo, Diamantina. FONTE: Acervo: (Lucio Costa) Instituto Antônio Carlos Jobim.

4. COSTA, Lucio. 1924. câmara principal; portas interna; coroamento; suporte de lanterna; vários estudos, Diamantina. FONTE: Acervo: (Lucio Costa) Instituto Antônio Carlos Jobim.

5. COSTA, Lucio. 1924. Coleção N. S. das Dores; estudos das fechaduras, Diamantina. FONTE: Acervo: (Lucio Costa) Instituto Antônio Carlos Jobim.

6. COSTA, Lucio. 1924. levantamento de muxarabi, Diamantina. FONTE: Acervo: (Lucio Costa) Instituto Antônio Carlos Jobim. 


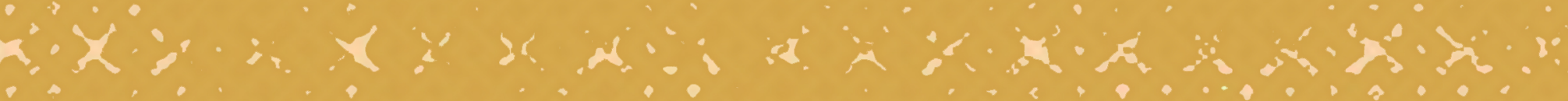

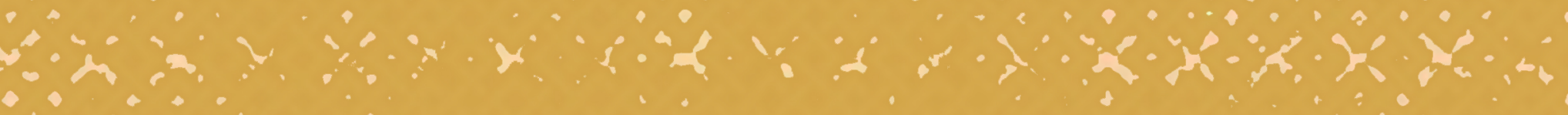

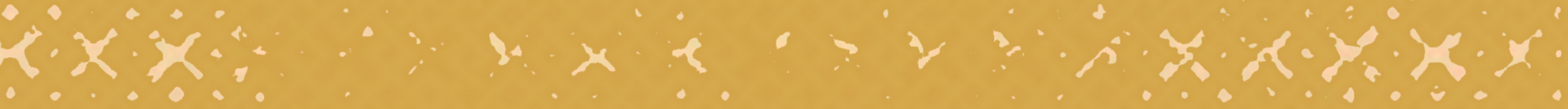
$\because x \times x-\because \quad x+x+x+x$

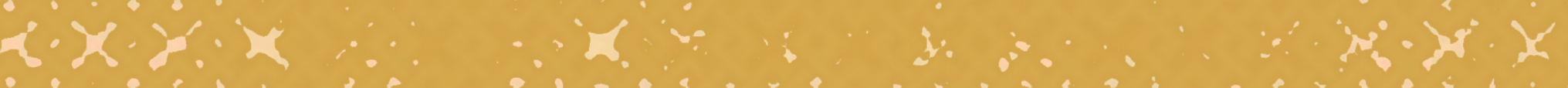
$x \times x \times x \times x \times x \times x \cdot x$

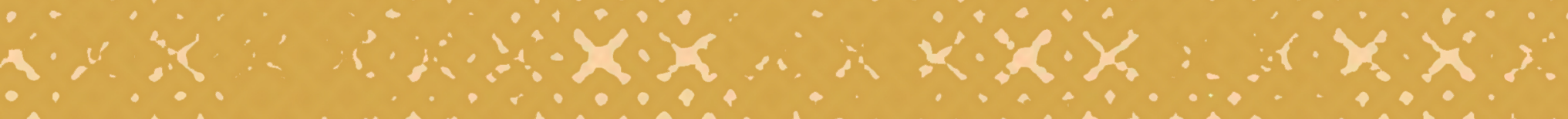
$\because \because x+x-x+x$

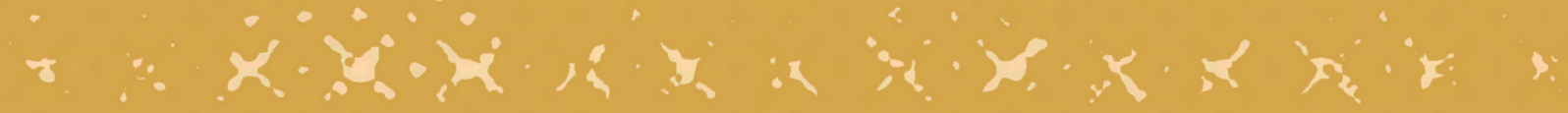

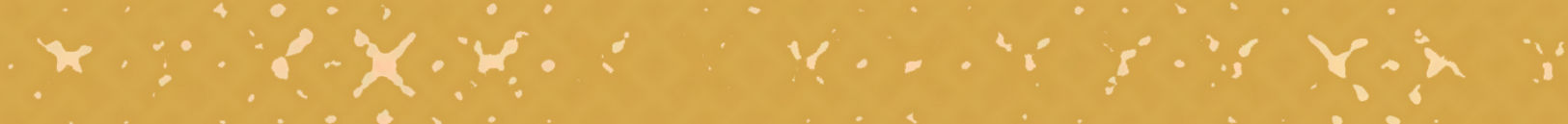

